\title{
Effecten van tijdprijzen op medische consumptie en gezondheid
}

Citation for published version (APA):

Janssen, R. T. J. M. (1989). Effecten van tijdprijzen op medische consumptie en gezondheid. [Doctoral Thesis, Maastricht University]. Rijksuniversiteit Limburg. https://doi.org/10.26481/dis.19890203rj

Document status and date:

Published: 01/01/1989

DOI:

10.26481/dis.19890203rj

Document Version:

Publisher's PDF, also known as Version of record

\section{Please check the document version of this publication:}

- A submitted manuscript is the version of the article upon submission and before peer-review. There can be important differences between the submitted version and the official published version of record.

People interested in the research are advised to contact the author for the final version of the publication, or visit the DOI to the publisher's website.

- The final author version and the galley proof are versions of the publication after peer review.

- The final published version features the final layout of the paper including the volume, issue and page numbers.

Link to publication

\footnotetext{
General rights rights.

- You may freely distribute the URL identifying the publication in the public portal. please follow below link for the End User Agreement:

www.umlib.nl/taverne-license

Take down policy

If you believe that this document breaches copyright please contact us at:

repository@maastrichtuniversity.nl

providing details and we will investigate your claim.
}

Copyright and moral rights for the publications made accessible in the public portal are retained by the authors and/or other copyright owners and it is a condition of accessing publications that users recognise and abide by the legal requirements associated with these

- Users may download and print one copy of any publication from the public portal for the purpose of private study or research.

- You may not further distribute the material or use it for any profit-making activity or commercial gain

If the publication is distributed under the terms of Article $25 \mathrm{fa}$ of the Dutch Copyright Act, indicated by the "Taverne" license above, 


\section{EFFECTEN VAN TIJDPRIJZEN}

OP

MEDISCHE CONSUMPTIE EN GEZONDHEID 



\section{EFFECTEN VAN TIJDPRIJZEN \\ OP \\ MEDISCHE CONSUMPTIE EN GEZONDHEID}

\section{PROEFSCHRIFT}

ter verkrijging van de graad van doctor aan de Rijksuniversiteit Limburg te Maastricht, op gezag van de Rector Magnificus, Prof.dr. F.I.M. Bonke, volgens het besluit van het College van Dekanen, in het openbaar te verdedigen op vrijdag 3 februari 1989 om 16.00 uur.

$$
\text { door }
$$

Richard Theodorus Johannes Marie Janssen geboren te Venray op 7 februari 1954 
Promotor:

Beoordelingscommissie:
Prof. Dr. F.F.H. Rutten

Prof. Dr. J.A.M. Maarse (voorzitter)

Prof. Dr. L.M.J. Groot

Prof. Dr. R.M. Lapré

Prof. Dr. A.P.W.P. van Montfort

Prof. Dr. W.P.M.M. van de Ven 
Aan Thei $†$ en To 


\section{INHOUDSOPGAVE.}

INLEIDING

1. TIJDPRIJSTHEORIE EN HAAR TOEPASSINGEN OP MEDISCHE

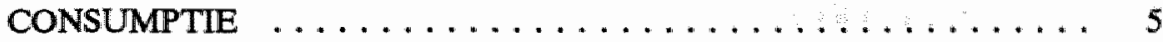

1.1. INLEIDING $\ldots \ldots \ldots \ldots \ldots \ldots \ldots \ldots \ldots \ldots \ldots$

1.2. DE TIJDPRIJSTHEORIE . . . . . . . . . . . . . 6

1.3. TOEPASSING VAN DE TIJDPRIJSTHEORIE BIJ DE VERKLARING VAN MEDISCHE CONSUMPTIE . . . . . . 10

1.4. DE ROL VAN TIJD IN DE INVESTERINGSGOEDBENADERING ......................... 16

1.5. MODELKEUZE EN NADERE AFBAKENING VAN DE

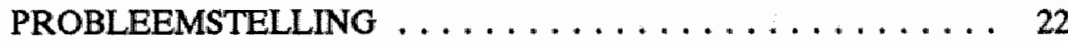

2. DATA EN MODELSPECIFICATIE $\ldots \ldots \ldots \ldots \ldots \ldots \ldots \ldots \ldots$

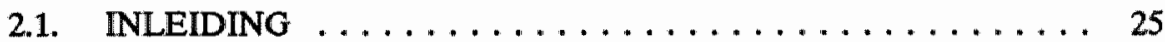

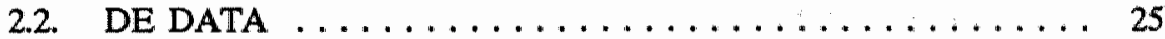

2.3. CONSUMPTIECATEGORIEEN EN MODELOPBOUW . . . . . 30

2.4. DE VERKLARENDE VARLABELEN $\ldots \ldots \ldots \ldots \ldots \ldots \ldots 33$

2.5. DE GEBRUIKTE ANALYSE TECHNIEK . . . . . . . . . . 39

3. HET EFFECT VAN TIJDPRIJZEN OP HUISARTSCONSULTEN . . 41

3.1. INLEIDING $\ldots \ldots \ldots \ldots \ldots \ldots \ldots \ldots \ldots \ldots \ldots . \ldots 41$

3.2. SPECIFICATIE VAN DE SCHATTINGSMODELLEN $\ldots \ldots \ldots, 42$

3.3. RESULTATEN $\ldots \ldots \ldots \ldots \ldots \ldots \ldots \ldots \ldots \ldots \ldots \ldots . \ldots \ldots$

3.3.1. Huisartsconsulten op eigen initiatief $\ldots \ldots \ldots \ldots \ldots, 47$

3.3.2. Huisartsconsulten niet op eigen initiatief $\ldots \ldots \ldots \ldots, 52$

3.4. BESPREKING EN CONCLUSIES $\ldots \ldots \ldots \ldots \ldots \ldots \ldots \ldots 54$

4. HET EFFECT VAN TIJDPRIJZEN OP HET GEBRUIK VAN

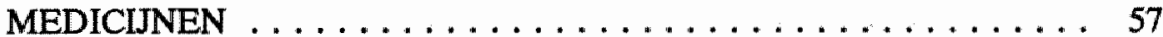

4.1. INLEIDING . . . . . . . . . . . . . . . . 57

4.2. SPECIFICATIE VAN DE SCHATTINGSMODELLEN $\ldots \ldots . \quad 59$

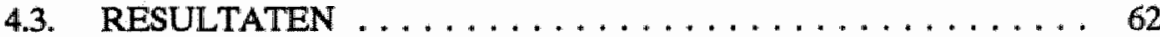

4.3.1. Medicijnen op recept ............... 62

4.3.2. Medicijngebruik niet op recept $\ldots \ldots \ldots \ldots \ldots \ldots \ldots 65$

4.4. CONCLUSIES . . . . . . . . . . . . . . . 67

5. HET EFFECT VAN TIJDPRIJZEN OP SPECIALISTCONSULTEN . . 69

5.1. INLEIDING . . . . . . . . . . . . . . . . . . . 69

5.2. SPECIFICATIE VAN DE SCHATTINGSMODELLEN $\ldots \ldots .70$

5.3. RESULTATEN $\ldots \ldots \ldots \ldots \ldots \ldots \ldots \ldots \ldots \ldots \ldots \ldots$

5.3.1. Eerste specialistconsult . . . . . . . . . . . . 74

5.3.2. Herhalingsconsulten bij de specialist . . . . . . . . 74

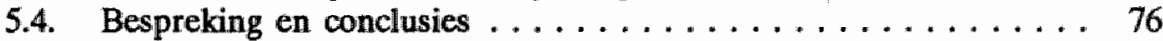


6. HET EFFECT VAN TIJDPRIJZEN OP OPNAME EN LIGDUUR

IN HET ZIEKENHUIS . . . . . . . . . . . . . . . . . . . . 79

6.1. INLEIDING . . . . . . . . . . . . . . . . . . . 79

6.2. SPECIFICATIE VAN SCHATTINGSMODELLEN $\ldots \ldots \ldots 80$

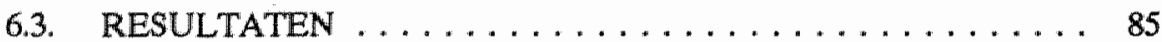

6.3.1. Opnamekans . . . . . . . . . . . . . 85

6.3.2. Ligduur . . . . . . . . . . . . . . . 87

6.4. SAMENVATTING EN CONCLUSIE . . . . . . . . . . . 89

7. HET EFFECT VAN TIJDPRIJZEN OP DE VRAAG NAAR

GEZONDHEID $\ldots \ldots \ldots \ldots \ldots \ldots \ldots \ldots \ldots \ldots \ldots \ldots \ldots \ldots$

7.1. INLEIDING . . . . . . . . . . . . . . . . . 91

7.2. THEORIE, VERWACHTINGEN EN MODELSPECIFICATIE . 92

7.3. RESULTATEN . . . . . . . . . . . . . . . . . . 98

7.3.1. Gezondheid als voorraadgrootheid $\ldots \ldots \ldots \ldots \ldots \ldots 98$

7.3.2. Gezondheid als stroomgrootheid $\ldots \ldots \ldots \ldots \ldots \ldots$

7.4. BESPREKING EN SAMENVATTING $\ldots \ldots \ldots \ldots \ldots \ldots$

8. MACRO-ECONOMISCHE KOSTENEFFECTEN VAN

TIJDPRIJZEN . . . . . . . . . . . . . . . . . . . . . . . . . . . . . . . . 107

8.1. INLEIDING . . . . . . . . . . . . . . . . . . . . . 107

8.2. GLOBALE CALCULATIE VAN INDIRECTE KOSTEN ..... 108

8.3. INDIRECTE KOSTEN PER CATEGORIE VAN MEDISCHE CONSUMPTIE .......................... 113

8.4. GEVOELIGHEIDSANALYSE $\ldots \ldots \ldots \ldots \ldots \ldots \ldots \ldots . \ldots \ldots$

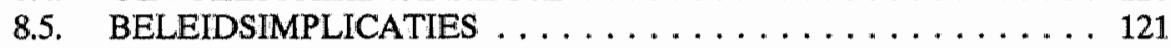

8.6. SAMENVATTING . . . . . . . . . . . . . . . . . . 124

9. SAMENVATTING . . . . . . . . . . . . . . . . . . . . . 127

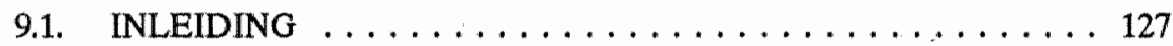

9.2. RESULTATEN . . . . . . . . . . . . . . . . . 128

9.3. BELEIDSIMPLICATIES . . . . . . . . . . . . . . . . 133

9.4. BEPERKINGEN EN SUGGESTIES VOOR VERDER ONDERZOEK $\ldots \ldots \ldots \ldots \ldots \ldots \ldots \ldots \ldots \ldots \ldots$

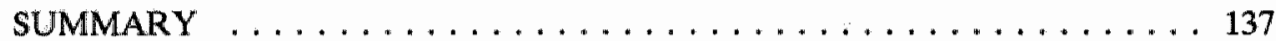

LITERATUURLIJST $\ldots \ldots \ldots \ldots \ldots \ldots \ldots \ldots \ldots \ldots \ldots \ldots \ldots$

LIJST VAN TABELLEN . . . . . . . . . . . . . . . . . . . . 149

LIJST VAN FIGUREN. $\ldots \ldots \ldots \ldots \ldots \ldots \ldots \ldots \ldots \ldots \ldots \ldots \ldots$

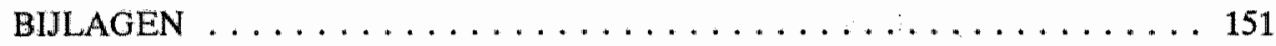

CURRICULUM VITAE $\ldots \ldots \ldots \ldots \ldots \ldots \ldots \ldots \ldots \ldots \ldots \ldots \ldots$ 
"Time waits for no one and it won't wait for me" is een waarheid ooit bezongen door Mick Jagger, die met name betekenis krijgt op het moment dat de promotiedatum vastligt. Wanneer je eenmaal jezelf daartoe verplicht hebt word je gedwongen om zeer bewust om te gaan met je eigen keuzes inzake tijdsbesteding. Op menig moment leidt dit tot de overweging of het allemaal wel de moeite waard is. Afgezien van de vraag of deze tijdsinvestering zich in materiële zin zal laten terugverdienen, heeft deze in elk geval haar opbrengsten in immateriële zin gerealiseerd. Het "afzien" brengt je dichterbij de niet tijdsgebonden aspecten van het menselijk zijn. Naar ik meen is dat niet de ratio maar het instinct en het gevoel. In die zin heeft het werken aan een proefschrift voor mij iets heel waardevols opgeleverd. Het is vergelijkbaar met het na het werk op de fiets beklimmen van de Keuterberg: Een prestatie die maatschappelijk nawwelijks van betekenis is, maar het feit dat je de meest extreme bronchiën hebt benut en de harikloppingen in je keel voelbaar waren, vervult je achteraf met voldaanheid.

In 1982 kwam ik te werken bij de vakgroep Economie van de Gezondheidszorg aan de Rijksuniversiteit Limburg en werd ik door Prof.Dr. F. Rutten in de gelegenheid gesteld deel te nemen aan het onderzoeksproject Determinanten van Gebruik van Gezondheidszorgvoorzieningen. Bij deze spreek ik mijn erkentelijkheid uit voor zijn stimulerende invloed die hij gedurende dit project op mij had. Daarnaast wil ik mijn collega Eddy Van Doorslaer bedanken voor zijn vakbekwame adviezen en suggesties waarmee hij mij voorzag. Mijn dank gaat verder uit naar Ellen Breevoort, die een belangrijk deel van de databewerking voor haar rekening nam, Maria Kalivas die de tekstverwerking verzorgde, Jan van Emmerik die de vormgeving van het manuscript uitwoerde, Wicher van Ettinger en Hans Severens, die achtereenvolgens als studentassistenten ondersteuning verleenden. Arnold Kester en Frans Tan dank ik voor hun adviezen op statistisch gebied. Daarnaast spreek ik mijn waardering uit aan de overige collega's die mij bij tijd en wijle op onderdelen bijstonden, te weten Brigitte Kerbusch, Ger Haan, Hans Trouw, André Ament, Robbert Huisman en mijn ex-collega's José Geurts, Reg van Steen en Nel van den Beucken.

Buiten mijn directe werkomgeving ben ik dank verschuldigd aan Jaap van den Berg, werkzaam bij het Centraal Bureau voor de Statistiek, die een constructieve rol heeft gespeeld bij de overdracht van de gegevens met betrekking tot de CBS-Gezondheidsenquête; an de medewerkers van het Medisch en Maatschappelijk Informatiecentrum van de Rijksuniversiteit Limburg die verantwoordelijk waren voor de feitelijke verwerving van de diverse databestanden en aan Theo Ackermans voor zijn redactionele adviezen.

Verder dank ik Prof.Dr. J. Maarse, Prof.Dr. L. Groot, Prof.Dr. R. Lapré, Prof.Dr. A. van Montfort en Prof.Dr. W. van de Ven voor hun bereidwilligheid lid te zijn van de beoordelingscommissie. Het is voor mij een grote eer dat de volledige verzameling van bekleders van leerstoelen op het terrein van Economie van de Gezondheidszorg in Nederland deel uitmaakt van de beoordelingscommissie.

Tot slot wil ik aan al diegenen die deel uitmaken van mijn sociale omgeving mijn grote waardering kenbaar maken voor de aanmoedigingen, aandacht, warmte en liefde die ik van hen en speciaal van Marleen Ackermans mocht ontvangen. 



\begin{abstract}
"Het woord "tijd" is een symbool voor een verband dat een groep wezens met het vermogen tot herinnering en synthese legt tussen twee of meer continua van veranderingen, waarvan er éen door hen wordt gebruikt als referentiekader of maatstaf om het andere (of de andere) te meten." (Elias, 1983).
\end{abstract}

In de Westerse landen wordt de gezondheidszorg grotendeels collectief via sociale verzekeringen of belastingen gefinancierd. Dit leidt ertoe dat economische overwegingen nauwelijks een rol lijken te spelen bij de keuze van een individu al of niet gebruik te maken van deze "gratis" voorzieningen. Deze schijn van afwezigheid van economische variabelen is echter bedrieglijk. Immers, ook al is er in veel gevallen geen sprake van een financieel offer bij het gebruik maken van gezondheidszorgvoorzieningen, er zal toch tijd gemoeid zijn met een bezoek aan bijvoorbeeld de huisarts. Omdat tijd bij uitstek een schaars goed is in ieders leven en op vele alternatieve manieren aan te wenden is, is het te beschouwen als cen economisch goed. Met andere woorden men mag veronderstellen dat in beslissingen waarin tijd een roll speelt, deze in de overweging betrokken wordt als een offer. De omvang van dit offer kan benaderd worden door middel van gederfde opbrengsten indien deze tijd op een alternatieve manier besteed zou worden. Deze gederfde opbrengsten worden in de economische literatuur aangeduid als zgn. "opportunity costs" of alternatieve kosten (van der Schroeff, 1970, p20 ev.).

De eventuele reis-, wacht- en behandeltijd die men kwijt is bij een bezoek aan bijvoorbeeld de huisarts zal derhalve functioneren als een prijs. In de economische theorie wordt de consument gezien als een individu dat rationeel handelt en haar eigen nut maximaliseert. Het voorgaande impliceert dan ook bij de afwezigheid van een geldelijke prijs, de $\mathrm{zg}_{\text {" }}$ "out of pocket prijs" of geldprijs, er een kosten-batenafweging 
In de jaren "70 toen in de Verenigde Staten de verzekeringsdekking ten aanzien van ziektekosten zich gestaag uitbreidde en er overwogen werd een nationale volksverzekering tegen ziektekosten in te voeren, werden er een reeks van studies gedaan naar de tijdprijseffecten op de vraag naar gezondheidszorg. Feldstein (1983) presenteerde een overzicht van de empirische resultaten van deze studies waaruit blijkt dat er elasticiteiten van het gebruik van gezondheidszorgvoorzieningen gevonden worden, varięrend van $-0,06$ tot $-1,0$.

Onderzoek naar de aanwezigheid en de omvang van tijdprijseffecten is onder meer relevant voor de volgende aspecten van gezondheidszorgbeleid (Muurinen en Le Grand, 1983). Op de eerste plaats is bij de afwezigheïd van geldprijzen de invloed van tijdprijzen op de witeindelijke verdelling van gezondheidszorg over sociaal-economische groepen van belang. Stimuleren of afremmen van de consumptie kan plaats vinden middels benvloeding van de tijdprijs. Instrumenten hierbij kunnen zijn de ruimtelijke planning van voorzieningen of de beinvloeding van de wachttijden. Daarnaast kan de invoering van geldprijzen in de vorm van bijv. eigen bijdrage viteenlopende effecten hebben. Beschouwen we immers de som van de tijdprijs en de eigen bijdrage in geld als de totale eigen bijdrage, dan zal de invoering van uniforme eigen bijdragen tot uiteenlopende procentuele verhogingen van totale eigen bijdrage leiden.

Op de tweede plaats zijn tijdprijzen van voorzieningen relevant voor de beoordeling van de maatschappelijke efficiëntie van de gezondheidszorg (Wolfson, 1988, p. 28). Deze kan immers niet beoordeeld worden zonder de tijdinputs van de patięnten in de kostencalculaties te betrekken (Holtman, 1972).

Ten derde hebben tijdprijskosten een relevantie voor beslissingen die betrekking hebben op de verdeling van de macro-economische kosten van de gezondheidszorg over een collectief en een privaat te financieren deel. De tijdprijskosten zouden op grond van economische overwegingen tot de maatschappelijke kosten van gezondheidszorg gerekend moeten worden. Verontachtzaming van dit kostenbestanddeel leidt tot cen systematische onderschatting van het privaat gefinancierde deel van de gezondheidszorg. In vergelijking met eigen bijdragen in geld, mag verondersteld worden dat gemiddeld genomen tijd een veel belangrijkere vorm van eigen bijdrage is.

Deze studie beoogt voor een 4-tal vormen van medische consumptie in Nederland na te gaan of en in welke mate tijdprijzen het gebruik benvloeden. Deze 4 vormen van medische consumptie zijn:

- Huisartsconsulten

- Medicijngebruik

- Specialistconsulten

- Ziekenhuisopnamen

In de hierboven geschetste benadering ter verklaring van medische consumptie speelt tijd de rol van een kostenfactor. Bij de opvatting, waarbij gezondheid beschouwd wordt als een vorm van human capital (Grossman, 1972a) speelt tijd daarnaast de rol van een opbrengstenfactor. Hierbij is gezonde tijd een functie van gezondheid. Deze gezondheid wordt door het individu "geproduceerd" waarbij medische voorzieningen, naast factoren als leefgewoonten, huisvesting en milieu-omstandigheden, een input in dit produktieproces zijn. Het rationeel handelend individu kiest dat gezondheidsniveau, 
waarbij de kosten van de produktie ervan nog gedekt worden door de opbrengsten, gemeten in extra gezonde tijd. Naarmate men tijd hoger waardeert zal men een hoger gezondheidsniveau aanhouden en daarmee samenhangend een geringer verlies aan productieve tijd in verband met ziekte hebben. In deze studie wordt middels een aantal schattingsmodellen onderzocht of deze relatie tussen tijdswaardering en gezondheidsniveau aantoonbaar is. Indien dit verband namelijk bestaat, kan hierin eveneens een belangrijke verklaring liggen voor het gegewen dat ondanks een uitgebreid aanbod van gezondheidszorgvoorzieningen en ontkoppeling van gebruik en betaling er nog steeds sprake is van ongelijke verdeling van gezondheid over sociaal-economische groepen (Townsend en Davidson, 1982; Mackenbach, 1987; Rutten en Janssen, 1987).

Vervolgens zal in deze studie een berekening plaatsvinden van de gemiddelde tijdprijs van een aantal voorzieningen. Op basis hiervan vindt een calculatie plaats van de totale tijdprijskosten van deze voorzieningen in Nederland. Nagegaan wordt wat de effecten van een verandering in de tijdprijzen op het gebruik respectievelijk de directe kosten zijn. Hierbij zal tevens aandacht besteed worden aan een aantal beleidsimplicaties van de gepresenteerde analyse.

Hieronder volgt een korte verwijzing naar de inhoud van de opeenvolgende hoofdstukken. In hoofdstuk 1 worden de theoretische modellen beschreven waarop deze studie gebaseerd is. Dit hoofdstuk eindigt met een nadere formulering van de vraagstellingen, die aan deze studie ten grondslag liggen. Schatting van de empirische modellen vindt plaats op basis van individuele gegevens verkregen uit de CBS-gezondheidsenquete van 1981. In hoofdstuk 2 vindt een beschrijving van de gebruikte gegevens plaats, waarbij aandacht wordt besteed aan de representativiteit van de onderzoekspopulatie. Daarnaast zullen in dit hoofdstuk enkele methodische aspecten van tijdswaardering en de gehanteerde schattingstechniek aan de orde komen. In de hoofdstukken 3, 4, 5 en 6 worden achtereenvolgens de gebruikte modellen voor de 4 genoemde vormen van medische consumptie gepresenteerd en worden de schattingsresultaten besproken. In hoofdstuk 7 worden de schattingsresultaten gepresenteerd van een tweetal modellen waarin niet de vraag naar medische voorzieningen, maar de vraag naar gezondheid verklaard wordt. Deze modellen zijn afgeleid van het eveneens in hoofdstuk 1 besproken investeringsmodel van Grossman. In hoofdstuk 8 vindt een berekening plaats van het aandeel van de tijdprijskosten in de totale kosten van de genoemde gezondheidsvoorzieningen. Daarnaast worden hier de effecten van veranderingen in gemiddelde tijdprijzen op het gebruik respectievelijk de kosten op macro-niveau gepresenteerd. Dit hoofdstuk eindigt met de opsomming van een aantal beleidsimplicaties. In hoofdstuk 9 wordt een samenvatting van de belangrijkste bevindingen van deze studie gegeven. 


\section{TIJDPRIJSTHEORIE EN HAAR TOEPASSINGEN OP MEDISCHE CONSUMPTIE}

"Geld kun je verspelen

En terugwinnen.

Stapel het op in je kist

En houdt het zo vast.

Tijd echter, tijd helaas, Als die voorbij is

Komt het nooit terug.

Geen zegel, slot

Of grendel kunnen ooit

Maken dat zij blijft".

(Wallin, 1863).

\subsection{INLEIDING}

In dit hoofdstuk wordt in paragraaf 2 de tijdprijstheorie beschreven en wordt uiteengezet wat haar aanvulling op de traditionele neo-klassieke theorie wan consumentengedrag is. Vervolgens wordt in paragraaf 3 een overzicht gegeven van haar toepassing in modellen ter verklaring van het gebruik van gezondheidszorgvoorzieningen. In deze modellen wordt gezondheidszorg beschouwd als een consumptiegoed. Het veronderstelde nut wordt direkt in de doelstellingsfunctie opgenomen.

In paragraaf 4 wordt ingegaan op de economische benadering waarbij gezondheid opgevat wordt als een investeringsgoed. In deze benadering spelen tijdprijzen zowel een rol aan de zijde van de kosten als van de opbrengsten. De vraag naar gezondheidszorg wordt hierbij beschouwd als een afgeleide van de vraag naar gezondheid. In de slotparagraaf worden de vraagstellingen wan deze studie nader geformuleerd. 


\subsection{DE TUDPRIJSTHEORIE}

De traditionele economische theorie van consumentengedrag gaal er van uit dat consumenten het beschikbare budget op zodanige wijze besteden dat het ervaren nut van de geconsumeerde goederen maximaal is (Samuelson, 1976). Prijsweranderingen van goederen leiden tot een verschuiving in bestedingsgedrag, ervan uiltgaande dat er over het algemeen substituten voorhanden zijn. Naast prijzen bepalen het inkomen en de voorkeuren van de consument mede het uiteindelijk verloop van de vraagfunctie.

In deze benadering wordt de vraagzijde van de markt vereenzelvigd met consumptief gedrag en de aanbodzijde van de markt met produktief gedrag. Dit impliceert dat consumentengedrag benaderd wordt in een zogenaamde vraagfunctie. Producentengedrag wordt benaderd door middell van een aanbodfunctie die afgeleid is van een zogenaamde produktiefunctie. Deze produktiefunctie geeft in feite de technische efficiënte combinaties weer van inputs met behulp waarvan een maximale hoeveelheid produkten kan worden voortgebracht (Heathfield en Wibe, 1987).

In de jaren "60 wordt er vanuit de zogenaamde "New Home Economics" kritiek geleverd op dit klassieke concept van consumentengedrag. Becker, die als grondlegger van deze stroming beschouwd kan worden (Siegers, 1985, p. 62) zet in het bekende artikel, "A theory of the allocation of time" (1965), deze kritiek uiteen en komt tot een integratie van de neo-klassieke theorie van het consumentengedrag met dat van het bedrijf:

In zijn "home production theory" nuanceert Becker het begrip consumptiegoed. Hij onderkent dat het nut van een goed meestal niet ontleend wordt aan het goed sec, maar dat zo'n goed zijn nuttigheid pas krijgt nadat er een aantal bewerkingen hebben plaatsgevonden. Zo zal de consument nauwelijks nut ontlenen aan het kopen van de consumptiegoederen rijst en groente. De nuttigheid zal pas ervaren worden op het moment dat deze goederen verwerkt zijn tot een maaltijd en de consument zich de tijd neemt om deze ook te consumeren. Uit dit voorbeeld wordt duidelijk dat de werkelijke prijs van de maaltijd niet de marktprijs van de rijst en de groente is. Er wordt immers ook tijd gestoken in de bewerking tot een maaltijd en het nuttigen van deze maaltijd. Deze tijd wordt als het ware onttrokken aan eventuele andere activiteiten en vertegenwoordigt hierdoor een bedrag aan alternatieve opbrengsten. Het is gebruikelijk deze gederfde opbrengsten als alternatieve kosten te bestempelen (Van der Schroeff, 1970 , p. 20 e.v.). Op grond hiervan concludeert Becker dat in de doelstellingsfunctie van de consument in eerste instantie niet de aangekochte marktgoederen moeten worden opgenomen maar het resultaat van de huishoudelijke produktie, waaraan uiteindelijk nut onleend wordt. Voor wat de terminologie betreft kan eveneens de vergelijking met de produktiesfeer worden doorgetrokken. Een deel van de aangekochte consumptiegoederen heeft het karakter van een intermediair goed (Odink en Schoorl 1984, p. 13). Pas na bewerking krijgen zij het karakter van een finaal consumptiegoed (commodity) waarvan men nut onlleent. Hieruit volgt tevens dat de werkelijke prijs van deze finale consumptiegoederen niet alleen bestaat uit de prijs van de aangekochte goederen maar ook uil de kosten van tijd die de voortbrenging van finale consumptiegoederen met zich mee brengt. Naast geldprijzen, de kosten van inputs van marktgoederen, dienen de tijdprijzen de kosten van de tijdinputs in de vraagfunctie te worden opgenomen. Dit laatste vindt plaats via de specificatie van een produktiefunctie. Middels een produktiefunctie worden alle mogelijke technisch efficiënte relaties tussen in- en outputs gespecificeerd (Heathfield en Wibe, 1987).

Deze produktiefunctie-benadering die tot dan toe betrekkelijk nieuw is voor consumentengedrag leidt ertoe dat niet alleen het niveau van marktprijzen van 
goederen relevant is voor de vraag maar eveneens de omvang van de alternatieve kosten van de benodigde tijdinputs.

Omdat deze benadering van consumentengedrag een centrale plaats inneemt in deze studie, wordt hierna het formele modell van Becker kort weergegeven:

De produktiefunctie $\left(\mathrm{f}_{\mathrm{i}}\right)$ van de finale consumptiegoederen $(\mathrm{Zi})$ luidt

$\mathrm{Z}_{\mathrm{i}}=\mathrm{f}_{\mathrm{i}}\left(\mathrm{x}_{\mathrm{i}}, \mathrm{T}_{\mathrm{i}}\right)$

waarin $x_{i}$ een vector van marktgoederen voorstelt en $T_{i}$ een vector van tijdinputs.

De doelstellingsfunctie wordt geformuleerd als

$U=U\left(Z_{1} \ldots Z_{m}\right)=U\left(x_{1} \ldots x_{m ;} ; T_{1} \ldots T_{m}\right)$

Deze doelstellingsfunctie wordt begrensd door de budgetrestrictie:

$\mathrm{g}\left(\mathrm{Z}_{\mathrm{i}} \ldots \mathrm{Z}_{\mathrm{m}}\right)=\mathrm{Z}$

Hierin is $g$ een uitgavefunctie van $Z_{i}$ en $Z$ geeft het niveau van beschikbare middelen weer.

Nu zal maximalisatie van de doelstellingsfunctie (2) plaatsvinden binnen de grenzen van het beschikbare geld- en tijdsbudget. Deze restricties kunnen als volgt omschreven worden:

a) De budgetrestrictie t.a.v. marktgoederen:

m

$\Sigma p_{p x_{i}}=I=V+T_{w} \bar{W}$

i

waarin $p_{i}$ een vector van prijzen is van $x_{i}$; het totale inkomen, welke bestaat uit nietarbeidsinkomen $(V)$ en $T_{w} \bar{W}$ de som van het arbeidsinkomen is $\left(T_{w}\right.$ is gewerkt aantal uren en $\bar{W}$ het gemiddelde uurloon).

b) De budgetrestrictie t.a.v. tijd

m

$\Sigma T_{i}=T_{c}=T-T_{w}$

i

waarin $T_{e}$ een vector is van de totale tijd beschikbaar voor consumptie en $T$ de totale beschikbare tijd.

Op basis van de produktiefunctie (1), kunnen de volgende gelijkheden afgeleid worden

$T_{i}=t_{i} Z_{i}$

$x_{i} \equiv b_{i} Z_{i}$ 
waarin $t_{i}$ een vector van time-inputs is per eenheid $Z_{i}$ en $b_{i}$ een vergelijkbare vector voor markigoederen.

Becker brengt de hierboven genoemde restricties terug tot een restrictie door te sitellen dat tijd is om te zetten in marktgoederen door in plaats van te consumeren meer te gaan werken.

$T_{w}$ in vergelijking (5) kan op basis van deze aanname gesubstitueerd worden met behulp van (6). Dit levert de nieuwe budgetrestrictie op,

$$
\sum_{i}^{m} p_{i} x_{i}+\sum_{i}^{m} T_{i} \bar{w}=V+T_{w} \bar{w}
$$

met behulp van (6) kan wergelijking (7) herschreven worden

$$
{\underset{i}{\mathrm{i}}\left(\mathrm{p}_{\mathrm{i}} \mathrm{b}_{\mathrm{i}}+\mathrm{i}_{\mathrm{i}} \overline{\mathrm{w}}\right) \mathrm{Z}_{\mathrm{i}}=V+T \bar{w}}^{\mathrm{m}}
$$

Bij definitie:

$$
\begin{aligned}
& \pi_{i} \mathrm{p}_{i} \mathrm{~b}_{i}+\mathrm{t}_{i} \overline{\mathrm{W}} \\
& \text { en } \\
& S^{\prime}=V+T \bar{W}
\end{aligned}
$$

Kortom de volledige prijs van een eenheid van goed $Z_{i}, \Pi_{i}$, bestaat uit de som van de prijzen van de verbruikte goederen (geldprijs) en van de verbruikte tijd (tijdprijs). De waardering van de tijd vindt plaats op basis van het gederfde loon. S' is een uitdrukking voor het geldinkomen in de situatie dat alle beschikbare tijd aangewend zou worden om inkomen te verdienen ("full income"). Onder de veronderstelling dat $\bar{W}$ constant is en onafhankelijk van $Z_{4}$ en dat in de produktiefunctie $b_{i}$ en $t_{i}$ vastliggen (Constänte opbrengsten) bij gegeven $p_{i}$ en $\bar{W}_{\text {, }}$ resulteert maximalisatie van de oorspronkelijke doelstellingenfunctie (2) onder conditie van (8) in de volgende evenwichtsvergelijking:

$$
U_{i}=\frac{\delta U}{\delta Z_{i}}=\lambda \Pi_{i}
$$

waarin $\lambda$ het marginale nut van het inkomen is. Deze evenwichtsvergelijking impliceert dat de consument zijn doelstelling in termen van nut maximaliseert in het punt waar het marginale nut van een finaal consumptiegoed $\left(Z_{i}\right)$ gelijk is aan het marginaal nut van de kosten hiervan uitgedrukt in (gederfd) inkomen.

Het belang van het hierboven beschreven model ten aanzien van consumentengedrag kan als volgt geformuleerd worden (Killingsworth, 1983). Op de eerste plaats wordt hiermee de tijdsbesteding van de consument binnen de zogenaamde vrije tijd 
analyseerbaar. Het keuzegedrag op dit gebied van het menselijk leven was tot dam toe nauwelijks door economen geanalyseerd. Op de tweede plaats maakt het model duidelijk dat de vraag naar bepaalde consumptiegoederen niet alleen amangt van de prijzen maar eveneens van de tijdprijzen als gevolg van de benodigde tijdinputs bij de omzetting tot de beoogde finale consumptiegoederen. Tot slot laat het model zien dat de vraag naar uren betaald werk niet alleen afhangt van het loon per uur maar ook van de benodigde tijd voor de produktie van finale consumptiegoederen binnen het huishouden.

Sharp (1981) geeft in zijn overzichtsstudie "The economics of time" het volgende commentaar op Becker's model van tijdsallocatie. Ten eerste stelt hij dat voorzover Becker het begrip "commodity" definieert deze voor kritiek vatbaar is. In feite definieert hij commodities als activiteiten waarbij aangekochte marktgoederen en tijdinputs zodanig gecombineerd worden, dat deze het beoogde nut opleveren. In sommige gevallen zal een marktgoed echter direct nut opleveren zonder dat hiervoor gebruik van tijd nodig is, bijvoorbeeld het roken van een sigaret tijdens het T.V. kijken. In andere gevallen zijn er vormen van tijdsbesteding waarbij er geen verbruik van marktgoederen optreedt, bijwoorbeeld mediteren. Ten tweede stelt Sharp dat sommige activiteiten niet direct nut opleveren, bijvoorbeeld het bereiden van een maaltijd, tenzij men de besparing van de prijs van een maaltijd in een restaurant als nut beschouwd. Ten derde stelt Sharp dat Becker de onbevredigende dichotomie tussen werk en vrije tijd wil opheffen maar deze in feite vervangt door een nieuwe dichotomie nl. betaald werk, dat inkomen als nut oplevert en huishoudelijk werk dat finale consumptiegoederen genereert. Andere nutseffecten dan inkomen van tijd besteed aan betaald werk zijn niet in Becker's model opgenomen. DeSerpa (1971) stelt dan ook dat Becker's model niet zozeer een algemene theorie wan tijdsbesteding is danwel een model voor consumentengedrag waarin het aspect van alternatieve kosten van aangewende tijd wordt meegenomen.

De hierboven aangehaalde kritiek van Sharp op Becker's model is voor een deel niet op zijn plaats. Zo onderkent Becker wel degelijk het fenomeen van "joint production" wat opgelost kan worden door de "joint costs" toe te rekenen aan de diverse finale consumptiegoederen. Voorzover er door Sharp en DeSerpa vraagtekens bij de reikwijdte van Becker's model geplaatst worden omdat deze de vraag naar werk reduceert tot de vraag naar inkomen is de onderkenning van de beperktheild van het model op zijn plaats. Het ligt voor de hand dat ook andere nutseffecten dan inkomen een rol spelen in de omvang van de tijdsbesteding voor betaald werk.

Tot slot formuleren Homan e.a. (1986) kritiek op de veronderstelling van rationeel nutsmaximaliserend gedrag die aan de "home production theory" ten grondslag ligt. Dit zou immers een continue adaptatie aan veranderende omstandigheden betekenen in een niet-stationaire wereld. Zij menen dat consumenten niet zozeer maximaliseren, maar een minimaal tevredenheidsniveau willen bereiken. Daarnaast zou met name het gedrag van vrouwen binnen huishoudens eerder door tradities bepaald worden dan door rationele nutsmaximalisatie. Ten tweede stellen $z i j$ vraagtekens bij de veronderstelling dat de arbeidstijd varieerbaar zou zijn. Uit hun onderzoek blijkt dat van de huishoudens waarvan een lid betaalde arbeid verricht, éen op de drie vindt dat zij te veel uren moeten werken en het resterende deel eigenlijk meer zou willen werken. Van mensen die geen werk hebben wil een belangrijk deel wel werken. Deze onvrijwillige werkeloosheid is een vorm van rantsoenering die optimaal gedrag in de 
weg staat: Deze kritiek is met name relewant als men de tijdbesteding zelf wil verklaren. In deze studie zal de tijd benodigd woor van medische consumptie als een exogene variabele worden opgevat. Derhalve biedt Becker's model een correcte conceptualisering van de prijselementen, die een rol spelen in de vraagfunctie van marktgoederen.

In de volgende paragraaf worden een aantal toepassingen besproken, waarbij medische diensten als een finaal consumptiegoed beschouwd worden. De vraagstelling hierbij is gericht op het effect van benodigde tijd als element wan de totale prijs op het gebruik van deze diensten. In paragraaf 4 komt de benadering aan de orde waarbij medische diensten worden opgevat als intermediaire goederen. Zij vormen naast andere factoren inputs voor het finale goed "gezondheid" of "gezonde tijd". Gezondheid wordt hilerbij opgevat als een goed met zowell het karakter van een final consumptiegoed als dat van een investeringsgoed. In deze benadering is de benodigde tijd voor het gebruik van voorzieningen een element van de kostprijs. Daarnaast ontleent het investeringsgoed "gezondheid" zijn waarde aan haar vermogen "gezonde tijd" te produceren.

\subsection{TOEPASSING VAN DE TIJDPRIJSTHEORIE BIJ DE VERKLARING VAN MEDISCHE CONSUMPTIE}

In eerste instantie is het tijdprijsconcept vooral toegepast in de arbeidsmarkt- en vervoerseconomie (zie voor een overzicht Siegers, 1985; Bruzelius, 1979). In de jaren '70 verschijnen er in de Verenigde Staten een aantal empirische studies die het concept toepassen bij de verklaring van het gebruik van gezondheidszorgvoorzieningen (Grossman, 1972a en 1972b; Acton, 1973a en 1973b; Phelps en Newhouse, 1974). Aanleiding hiervoor was dat het risico op gebruik van medische voorzieningen in de Verenigde Staten steeds meer volledig verzekerd werd, zodat de tijdcomponent een relatief belangrijkere economische determinant van de vraag naar medische voorzieningen werd. Hierna wordt eerst ingegaan op de studie van Acton (1973a). Het door hem ontwikkelde model is in feite een toepassing van Becker's algemene model op het gebruik van gezondheidszorgvoorzieningen. Aan het einde van de paragraaf zal aandacht besteed worden aan enkele meer recente studies van Coffey (1983), Leibowitz (1984) en Cauley (1987) voor zover deze methodologische relevantie hebben voor het onderhavige onderzoek.

Acton (1973a) specificeert in zijn studie een theoretisch model ter verklaring van de vraag naar gezondheidszorg, met behulp waarvan hij de effecten van geld- en tijdprijzen als ook van inkomen uit arbeid en overig inkomen op de vraag hiernaar kan voorspelllen. In de doelstellingsfunctie onderscheidt hij twee soorten goederen en diensten, te weten medische goederen en diensten $(m)$ en alle overige goederen en diensten $(X)$.

$\mathrm{U}=\mathrm{U}(\mathrm{m}, \mathrm{X})$

De doelstellingsfunctie wordt gemaximeerd onder de volgende budgetrestrictie:

$(p+w t) m+(q+w s) X \leq Y$

waarbij $Y=y+w^{\prime} T$ 
De gebruikte symbolen hebben de volgende betekenis:

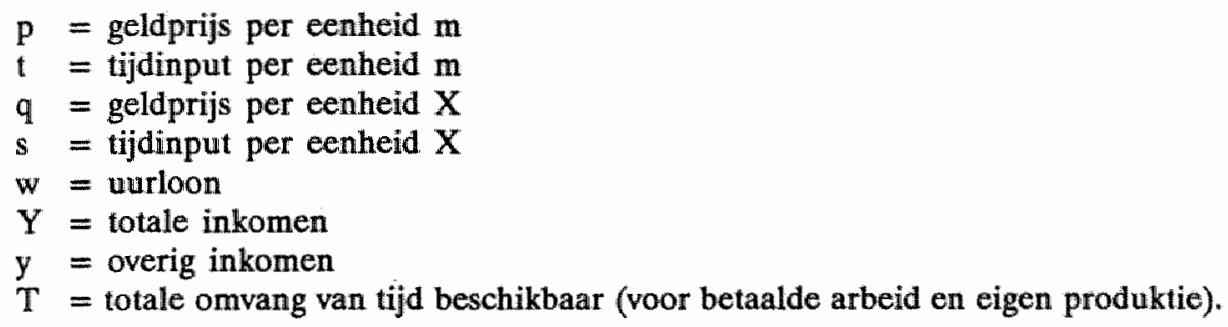

De analogie met de budgetrestrictie in Becker's model, zie vergelijking 8 , in de vorige paragraaf moge duidelijk zijn. De kosten van de medische goederen en diensten zijn onderscheiden in geld- en tijdprijzen. De som van deze inputs, in geld uitgedrukt, wordt begrensd door het maximaal te verdienen inkomen $(\mathrm{Y})$. Dit inkomen wordt onderscheiden in maximaal te verdienen inkomen uit arbeid (wT) en overig inkomen (y). De tijdsbudgetrestrictie is getransformeerd tot een element van de geldbudgetrestrictie door de tijd te waarderen op basis van het uurloon. Verondersteld wordt dat bij de consumptie van $m$ en $\mathrm{X}$ de aandelen van de geld- en tijdprijs in de totale prijs vast liggen.

Uit het hierboven gespecificeerde model kunnen nu de effecten van prijs- en inkomensveranderingen op de vraag naar medische goederen en diensten worden afgeleid. Hierna worden de voorspelde effecten van de veranderingen besproken. Voor de formele afleiding wordt verwezen naar bijlage 1 .

Allereerst wordt het effect van een verandering in de geld- en tijdprijs besproken. Uit de afleiding van de optimumcondities van het model, onder de veronderstelling dat medische goederen en diensten functioneren als normale goederen, blijkt dat de tijdprijs functioneert als een geldprijs. Beide hebben een negatief effect op het niveau van gebruik (zie bijlage 1).

Om zicht te krijgen op de onderlinge relatie worden de beide prijselasticiteiten in relatie gebracht tot de totale prijselasticiteit: $\eta_{m(p+w t)}$

Het relatieve aandeel van de geldprijselasticiteit $\left(\eta_{\mathrm{mp}}\right)$ in de totale prijselasticiteit $(\eta \mathrm{m}(\mathrm{p}+\mathrm{w})$ ) kan nu als volgt gespecificeerd worden (zie voor afleiding de bijlage 1)

$$
\eta_{\mathrm{mp}}=\frac{\mathrm{p}}{(\mathrm{p}+\mathrm{wt})} \eta_{\mathrm{m}(\mathrm{p}+\mathrm{wt})}
$$

terwijl het relatieve aandeel van de tijdprijselasticiteit $\left(\eta_{\mathrm{m}(\mathrm{wt})}\right)$ de volgende vorm krijgt (zie bijlage 1 ):

$$
\eta_{\mathrm{m}(\mathrm{wt})}=\frac{\mathrm{wt}}{(\mathrm{p}+\mathrm{wt})} \eta_{\mathrm{m}(\mathrm{p}+\mathrm{wt})}
$$


Deze laatste vergelijkingen laten zien dat de prijselasticiteit van één van de prijscomponenten gelijk is aan de totale prijselasticiteit vermenigvuldigd met het aandeel van de betreffende prijscomponent in de totale prijs. Het voorgaande impliceert dat de geld- en tijdprijselasticiteit zich kunnen verhouden als

$$
\eta_{\mathrm{s}(\mathrm{W})} \stackrel{\geq}{<} \eta_{\mathrm{mp}}
$$

afhankelijk van het gegeven of wt $\frac{2}{<}$.

Met andere woorden de vraag naar (m) zal relatief gevoeliger zijn voor dat deel van de prijscomponent dat het grootst is. Een concreet voorbeeld moge dit verduidelijken. Indien de totale prijs van m bijvoorbeeld f100,-- bedraagt, welke is opgebouwd uit een geldprijs van $\mathrm{f} 40$,-- en een tijdprijs van f60,-- en de prijselasticiteit bedraagt, laten we aannemen $-0,5$, dan zijn de prijselasticiteiten van de prijscomponenten als volgt te berekenen. De geldprijselasticiteit bedraagt $40 / 100$ maal $-0,5=-0,2$ en de tijdprijselasticiteit bedraagt $60 / 100$ maal $-0,5=-0,3$. Wordt het aandeel van de geldprijscomponent verkleind, bijvoorbeeld als gevolg van een uitbreiding van de verzekeringsdekking, dan zal de vraag naar het betreffende goed relatief gevoeliger worden voor veranderingen in de tijdprijscomponent. Dit betekent dat over het algemeen de vraag naar medische voorzieningen, waarvoor de geldprijs gelijk aan nul is, relatief gevoeliger is voor veranderingen in de tijdprijs dan de vraag naar voorzieningen met een geldprijs groter dan nul. Omgekeerd zal de invoering van een gelijke eigen bijdrage voor iedereen (bijvoorbeeld voor een verwijzing naar de specialist) tot verschillen in vraageffecten leiden, omdat de relatieve aandelen van de prijscomponenten nu eenmaal individueel variëren. Dit alles onder de veronderstelling dat de vraag gekenmerkt wordt door een zekere prijsgevoeligheid.

Hierna worden de effecten van een inkomensverandering op de vraag naar medische goederen en diensten besproken. Hierbij is het verschil in het eerder gemaakte onderscheid tussen inkomen uit arbeid en overig inkomen van belang. (Voor de formele afleiding wordt naar bijlage 1 verwezen).

Een toename van het overige inkomen heeft, onder de veronderstelling dat $\mathrm{m}$ geen inferieur goed is, een positief effect op de vraag naar $\mathrm{m}$. Een toename van het inkomen uit arbeid leidt tot een minder eenduidig te voorspellen effect. $\mathrm{Nu}$ is er immers sprake van zowel een (positief) inkomenseffect, als van een substitutie-effect. Dit laatste treedt op als gevolg van het feit dat de tijdprijzen en daarmee de totale prijzen van $\mathrm{X}$ en $\mathrm{m}$ beïnvloed worden door de toename van dit type inkomen. Van belang hierbij is te beseffen, dat het gaat om een inkomenseffect dat optreedt als gevolg van een wijziging in de loonvoet en niet in het aantal gewerkte uren. Nu hangt het van de relatieve aandelen van de tijdprijscomponenten in goederen $\mathrm{m}$ en $\mathrm{X}$ af of er sprake is wan een positief of negatief substitutie-effect. Uit het formele model (zie bijlage 1) kan afgeleid worden dat indien

$\frac{w s}{(q+w s)}>\frac{w t}{(p+w t)}$


er sprake zal zijn van een positief substitutie-effect. In dit geval is het relatieve aandeel van de tijdprijscomponent in de totale prijs van goed $X$ groter dan van goed $\mathrm{m}$. Anderzijds zal in het geval dat $m$ volledig verzekerd is $(p=0)$ en $X$ niet gratis verkrijgbaar is $(q>0)$, het substitutie-effect negatief zijn. Dit laatste betekent dat bij een toename van de loonvoet (ceteris paribus) er ten alle tijde een negatiof substitutie-effect zal optreden ten aanzien van goederen met een geldprijscomponent die gelijk is aan nul. Het uiteindelijke effect van een wijziging in de loonvoet zal bepaald worden door het saldo van het positieve inkomenseffect en het mogelijk negatieve substitutie-effect. Op basis van het formele model kunnen over het saldo van beide effecten niet a priori uitspraken worden gedaan (zie ook de bespreking van Becker's model bij Siegers, 1985 , p. 61). In het geval dat er sprake is van goederen met een geldprijs gelijk aan nul, is het aannemelijk dat een verandering in de loonvoet voornamelijk een prijseffect en derhalve een negatief effect op de vraag naar deze goederen zal veroorzaken. Met andere woorden, de inkomenselasticiteit van voorzieningen met een geldprijs nul zal lager zijn dan van voorzieningen met een geldprijs groter dan nul.

De belangrijkste hypothesen die van het hiervoor besproken model kunnen worden afgeleid ten aanzien van de vraag naar gezondheidszorg kunnen als volgt worden samengevat:

1. De tijdprijs van medische voorzieningen zal functioneren als een normale prijs met een negatief effect op het gebruik van medische voorzieningen en bij de aanwezigheid van substituten met een positief kruisprijseffect op het gebruik van deze substituten.

2. De vraag naar medische voorzieningen met een geldprijs gelijk aan nul zal relatief gevoeliger zijn voor veranderingen in tijdprijzen dan wanneer deze geldprijzen aanwezig zijn.

3. Het effect van een verandering in overig inkomen op de vraag naar medische voorzieningen zal eenduidig positief zijn.

4. Het effect van een verandering in de loonvoet (inkomen uit arbeid) wordt door het model niet eenduidig voorspeld. Aannemelijk is dat in geval een geldprijs afwezig is, het tijdprijseffect zal domineren en er derhalve sprake zal zijn van een negatief vraageffect.

Voordat we de bespreking van Acton's model afsluiten is het op zijn plaats om op een aantal verschillen met Becker's benadering te wijzen. Op de eerste plaats specificeert Acton de doelstellingsfunctie niet nader in termen van beoogde nuttigheden warvan middels een produktie-functie de inputs van tijd en geld gegeven worden. Acton neemt de aan te kopen marktgoederen direct in de doelstellingsfunctie op en beschouwt deze als finale consumptiegoederen. Hij beschouwt de benodigde tijdinputs als noodzakelijke verwervingskosten van de aan te kopen goederen, die gegeven zijn. Op deze wijze laat Acton het idee van substitueerbaarheid tussen tijdinputs en medische zorg feitelijk los en past hij de budgetrestrictie aan het gegeven van tijdprijzen aan. De voorspelde effecten van beide modellen van tijdprijs- en inkomensveranderingen op het niveau van de vraag naar consumptiegoederen zijn gelijk.

De schattingsresultaten van Acton's empirische model bevestigen in grote lijnen de hypothesen die zijn theoretisch model genereren en die hierboven samengevat zijn. Hij schat voor een viertal voorzieningen elasticiteiten voor reis- en wachttijden én voor 
inkomen uit arbeid en overig inkomen. Hij vindt significante negatieve tijdprijselasticiteiten warierend van $-0,25$ tot $-1,0$ voor reistijd en van $-0,05$ tot $-0,12$ voor wachttijden. De gevonden inkomenselasticiteiten zijn minder eenduidig qua teken. De oorzaak hiervan kan bij inkomen uit arbeid gevonden worden in de dominantie van of het negatieve substitutie-effect of het positieve inkomenseffect. Bij het overig inkomen kan de verklaring voor het niet voorspelde negatieve effect gevonden worden in het inferieure karakter van sommige voorzieningen in de Verenigde Staten.

In het vervolg van deze paragraaf wordt een kort overzicht gegeven van andere studies op het terrein van tijdprijseffecten op het gebruik van gezondheidszorgvoorzieningem. De studie van Phelps en Newhouse (1974) is gebaseerd op een vergelijkbaar model als dat van Acton. Centraal hierbij stond het effect van veranderingen in de procentuele bijdragen van verzekerden, rekening houdend met de variaties in de tijdprijscomponent voor diverse voorzieningen. $\mathrm{Bij}$ een relatief groot aandeel van de tijdprijscomponent van de betreffende voorziening verwacht men een relatief laag effect van de procentuele bijdrage die beschouwd wordt als de prijscomponent en relatief hoge tijdprijselasticiteiten. Met andere woorden, de gevonden variatie in hef effect van een verandering in de procentuele bijdrage op het niveau van het gebruik van voorzieningen wordt verondersteld samen te hangen met het relatieve aandeel van de geldprijscomponent en de tijdprijscomponent. De gevonden resultaten bevestigen in grote lijnen de verwachte samenhang. Voorzieningen met een relatief hoge tijdprijs zoals een bezoek aan de huisarts zijn in het algemeen relatief ongevoelig voor een verandering in de procentuele bijdrage (elasticiteit bedraagt -0,14). Terwijl bij voorzieningen met een relatief hoge geldprijscomponent zoals artsbezoek aan huis, een geldprijsellasticiteit van $-0,37$ wordt gevonden. De essentie van deze studie is dat invoering van een gelijke procentuele eigen bijdrage uiteenlopende effecten op het niveau van de vraag naar voorzieningen zal hebben. Deze verwachting wordt empirisch bevestigd.

In een studie van Holtman (1972) wordt voor de Verenigde Staten een berekening gemaakt van het aandeel van de indirekte kosten van ziekenhuisopname in de totale kosten. Deze indirecte kosten zijn berekend op basis van de gemiddelde opname-duur en het inkomen per dag. Uit de becijfering blijkt dat deze indirecte kosten in 1947 $19 \%$ van de directe kosten bedroegen en in 1967 nog $11 \%$. Daarnaast presenteert hij in deze studie een verdeling van het gebruik van een aantal voorzieningen naar inkomensgroepen. Hierbij wordt de veronderstelling bevestigd dat groepen met een hoog inkomen per uur bij de mogelijkheid tot substitutie die voorzieningen zullen kiezen, die minder tijdsintensief zijn. Daarnaast blijkt uit de door hem gepresenteerde gegevens dat hogere inkomensgroepen een kortere gemiddelde verpleegduur hebben. Dit laatste zou een bevestiging kunnen zijn voor de dominantie van het negatieve substitutie-effect over het positieve inkomenseffect in geval de kosten van voorzieningen door de verzekering gedekt wordt.

Coffey (1983) wijst in haar studie op het effect van het niet opnemen van de tijdprijzen van andlere goederen in de empirische vraagfuncties van medische goederen en diensten. Juist omdat deze door verschillen in de individuele loonvoet aanmerkelijk kunnen variëren wordt door het weglaten van deze variabele de tijdprijselasticiteit van de vraag naar medische goederen onderschat. Immers het effect van een verandering in de loonvoet op de vraag naar medische voorzieningen is mede afhankelijk van de totale prijs van de overige goederen. Het weglaten van de geldprijs van overige 
goederen is geoorloofd daar deze voor iedereen als gelijk werondersteld kan worden. Dit geldt echter niet voor de kruistijdprijzen. Het niet opnemen van deze variabele in het empirische model leidt in een dergelijke situatie tot een onderschatting van de tijdprijsellasticiteit. Immers de loonvoet en de tijdprijs hangen over het algemeen positief samen, terwijl de eerste variabele als kruistijdprijs een positieve en de tweede variabele een negatieve samenhang met medische consumptie zullen vertonen. Coffey hanteert in haar studie gegevens met betrekking tot het gebruik van gynaecologische voorzieningen. Uit de analyse hiervan blijkt dat de tijdprijs een sterke rol speelt bij de keuze van een voorziening. $\mathrm{Zij}$ vindt een tijdprijjselasticiteit van $-0,48$. Ten aanzien van de kans op een contact vindt zij een elasticiteit van $-0,10$, terwijl ten aanzien van het aantal contacten binnen een bepaalde periode geen significant effect van tijdprijzen meer gevonden wordt.

Leibowitz (1984) gaat in haar studie in op het probleem van de tijdswaardering. Het meestal gehanteerde loon als een benadering van de alternatieve kosten van tijd is voor diverse groepen veelal niet voor handen. Men kan hierbij denken aan huiswrouwen en uitkeringsgerechtigden. Daarnaast wordt bij een dergelijke waardering geen rekening gehouden met specifiek ervaren positief of negatief nut van de benodigde tijd. Middels een enquete onder deelnemers aan het Rand-experiment (zie voor een beschrijving Manning e.a., 1987) meet zij een in geld uitgedrukte waardering van reis- en behandeltijden wan individuen.

De op deze wijze gevonden tijdswaardering voor behandeltijd ligt op groepsniveau gemiddeld ongeveer 2 maal zo hoog als het uurloon. Op individueel niveau wordt een significante correlatiecoëfficiënt van 0,17 tussen beide variabelen gevonden. De waardering van de reistijd ligt op groepsniveau dichter bij het uurloon. Echter ook hier wordt een significante correlatiecofficiënt van slechts 0,12 gevonden. Leibowitz zelf geeft een tweetal mogelijke verklaringen voor deze resultaten. Op de eerste plaats zouden deze een uitdrukking kunnen zijn van het negatieve nut dat geïnterviewden verbinden aan een doktersbezoek, dat blijkbaar aanmerkelijk varieert binnen een bepaalde uurloongoep. Ten tweede zouden deze resultaten te wijten kunnen zijn aan de mate waarin middels het experiment de tijdswaardering daadwerkelijk gemeten is. De vragen werden immers op grond van denkbeeldige situaties gesteld. Leibowitz maakt in haar rapportage geen melding van de mate waarin de genoemde variabelen een bijdrage leveren aan een eventuele verklaring van het feitelijk gebruik van gezondheidszorgvoorzieningen. Ondanks deze beperking wijst haar studie wel op de relevantie van de manier waarop men aan de gegevens over tijdswaardering komt.

Bruzelius $(1979$, p. 146) onderscheidt drie methoden met behulp waarvan gegevens over tijdswaardering verkregen kunnen worden. Bij de eerste methode contrueert de onderzoeker de tijdswaardering bijwoorbeeld op basis van het individuele uurloon. Deze benadering is in onderzoek naar medische consumptie veel toegepast. Bij de tweede methode zijn de data gebaseerd op rapportering door de respondent die in een denkbeeldige situatie voor een keuze wordt geplaatst. In het hiervoor aangehaalde onderzoek van Leibowitz wordt dit toegepast. Het gaat hierbij om intentioneel gedrag, verkregen in een experimentele situatie. Bij de derde benadering zijn de gegevens gebaseerd op feitelijk gedrag van de consument, in situaties dat deze kan kiezen tussen alternatieven met uiteenlopende tijdinputs en prijzen. De hierna te bespreken studie van Cauley (1987) is gebaseerd op deze derde benadering. 
Caulley berekent met behulp van een empirisch model elasticiteiten van de geldprijscomponent en de ongewaardeerde tijdcomponent. Uit deze elasticiteiten leidt hij vervolgens met behulp van de onderstaande relatie de marginale waardering van tijd aif.

$w_{m}=\frac{\eta_{m p}}{\eta_{m}}=\frac{\mathbb{B}^{t}}{\mathfrak{B}^{m}}$

In deze relatie staat w voor de marginale tijdswaardering en zijn $\mathbf{B}^{t}$ en $\mathbf{B}^{\mathrm{m}}$ de geschatte partiele correlatie-coefficiênten van de ongewaardeerde tijdcomponent $t$ en de geldprijscomponent p. De overige symbolen hebben dezelfde betekenis als in de vorige paragraaf. Op deze wijze wordt een tijdswaardering berekend van $\$ 5,86$, terwijl deze op grond van geobserveerde uurlonen $\$ 5,50$ zou bedragen. Dit zijn gegevens van personen met een full-time betaalde baan in 1975. Cauley komt op grond van deze resultaten tot de conclusie dat voor een populatie met deze kenmerken blijkbaar het saldo van de subjectief ervaren positieve en negatieve nutseffecten klein is. Hierdoor kan het uurloon toch functioneren als een benadering voor de subjectieve tijdswaardering. Het is een beperking van deze studie dat het verband tussen deze twee variabelen door het ontbreken van gegevens met betrekking tot individuele inkomens niet op individueel niveau onderzocht konden worden.

Uit het in deze paragraaf geschetste overzicht van studies kunnen de volgende conclusies getrokken worden. Op de eerste plaats is het model van Acton adequaat om het effect van tijdprijzen op medische consumptie te onderzoeken, onder de aanname dat medische diensten op zijn minst voor een deel als finale consumptiegoederen zijn op te vatten met een eigen nut. Ten tweede worden in al deze studies significante effecten gevonden, hetgeen er op wijst dat de benodigde tijd functioneert als een prijs. Ten derde wijzen de waarden van de gevonden elasticiteiten in de richting dat het om een relatief sterke invloed van de tijdprijs gaat die relatief in betekenis toeneemt naarmate het aandeel van de tijdprijs in de totalle prijs tocneemt. Ten vierde is het meten van de tijd in waarde-termen problematisch, wanneer het gaat om individuen zonder lihkomen ot" met voornamelijk" overig inkomen (íncl: uitkering).

In deze paragraaf zijn benaderingen beschreven waarin gezondheidszorg wordt opgevat als een goed dat op directe wijze een bijdrage levert aan het ervaren nut. In de volgende paragraaf wordt een benadering besproken waarbij gezondheidszorg wordt opgevat als een intermediair marktgoed, dat eến van de inputs vormt in de produktie van gezondheid.

\subsection{DE ROL VAN TIJD IN DE INVESTERINGSGOED-BENADERING}

Grossman (1972a, 1972b) formuleerde een modell, waarin hij eveneens geinspireerd door Becker's concept van de huishoudproduktiefunctie, gezondheid beschouwt als een zelf te produceren finaal goed. Hierbij vat Grossman het finale goed gezondheid op als een vorm van human capital, vergelijkbaar met bijwoorbeeld opleiding. In zijn model brengt de voorraad gezondheid 2 typen van opbrengsten voort. De eerste opbrengst is het direct ervaren consumptieve nut van "het gezond zijn". Het tweede type opbrengst. 
is dat de voorraad gezondheid "gezonde tijd" voortbrengt die op zich weer kan functioneren als input bij de produktie van andere finale goederen. Grossman specificeert voor beide type opbrengsten aparte modellen, het consumptierespectievelijk het investeringsmodel. In het vervolg zal voornamelijk aandacht aan het investeringsmodel besteed worden omdat dit in tegenstelling tot het consumptiemodel zich onderscheidt in de gedragswoorspellingen ten opzichte van de in de vorige paragraaf beschreven benaderingen.

Het voorgaande impliceert dat tijd in dit model zowel een rol speelt in de kosten van de produktie van gezondheid als bij de waardering van de opbrengst van gezondheid. Het naar maximaal nut strevend individu zal doorgaan met het produceren van extra gezondheid tot dat de marginale produktiekosten de marginale opbrengsten ervan evenaren. Deze situatie wordt in onderstaande relatie weergegeven.

$W_{i} G_{i}$

$\overline{\Pi_{i-1}}=\gamma_{i}$

Hierbij is $W_{i}$ het dagloon in periode $i$ en $G_{i}$ het aantal extra gezonde dagen dat de laatste eenheid gezondheid voortbrengt. De term $W_{i} G_{i}$ drukt derhalve de marginale opbrengst uit van een investering in gezondheid. $\Pi_{\mathrm{i}-1}$ heeft betrekking op de marginale kosten van deze laatste eenheid gezondheid verbonden met de inputs van gekochte goederen en tijd in de voorgaande periode. De waarde van het verhoudingsgetal $\gamma_{1}$ geeft de opbrengstvoet van een investering in gezondheid weer.

Figuur 1.1. De vraag naar gezondheidskapitaal. (Bron: Grossman 1972b)

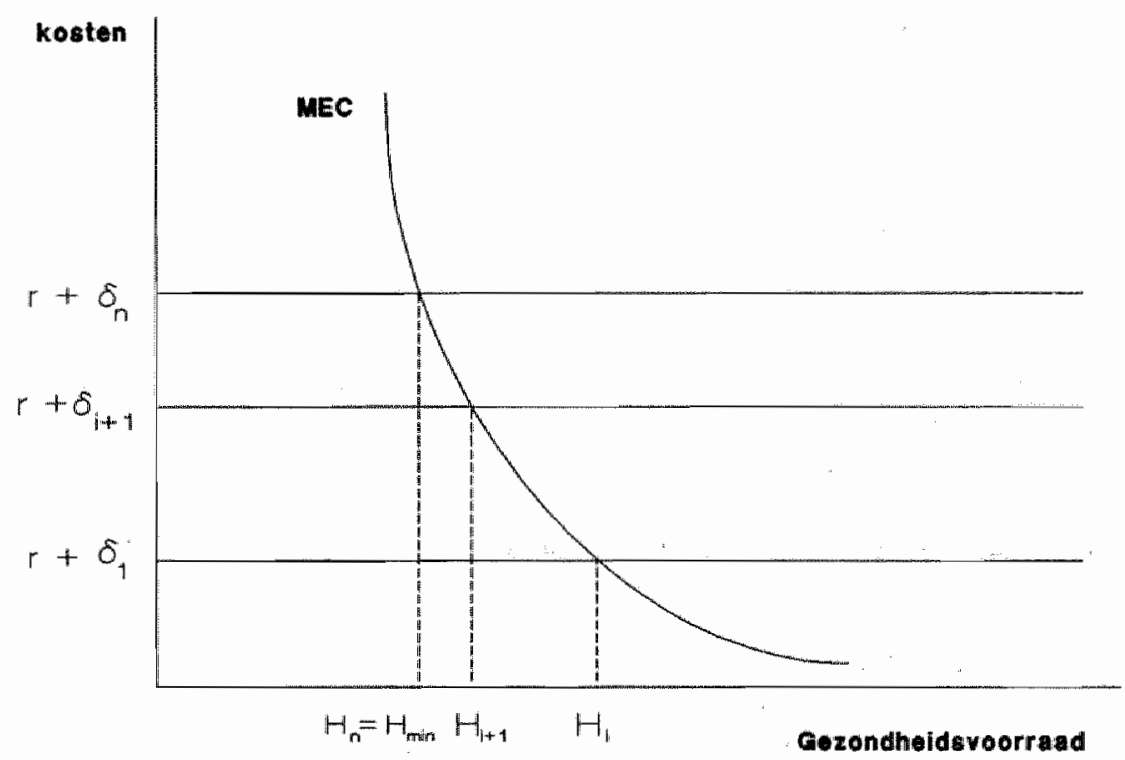


Grossman noemt deze verhouding tussen de marginale opbrengst en de marginale kosten de marginale efficièntie van gezondheidskapitaal $(\gamma)$. Deze zal tenderen af te nemen naarmate de voorraad gezondheidskapitaal toeneemt. In figuur 1.1. wordt het verloop van deze marginale efficięntie weergegeven in de zogenaamde marginale efficientie curve (ME-curve).

Zijn benadering van gezondheid als een woorraad kapitaal impliceert dat de feitelijke voorraad gezondheid in de i-de periode bepaald wordt door een drietal grootheden (zie figuur 1.2.). Naast de geërfde beginvoorraad wordt de voorraad gezondheid bepaald door enerzijds gezondheidsbevorderende activiteiten (investeringen) en anderzijds het "verbruik" van deze voorraad. Het laatste proces volgt ondermeer uit het natuurlijke proces van ouder worden, en wordt door Grossman gekwantificeerd middels de depreciatievoet. Hij beschouwt deze depreciatievoet als een exogene, die toeneemt met de leeftijd en door deze laatste variabele benaderd wordt. Dit verbruiksproces kan (deels) gecompenseerd worden door investeringen in de vorm van gezondheidsbevorderende activiteiten zoals gezonde voeding, lichamelijke training en het gebruik maken van gezondheidszorgvoorzieningen.

Figuur 1.2. Determinanten van gezondheidskapitaal

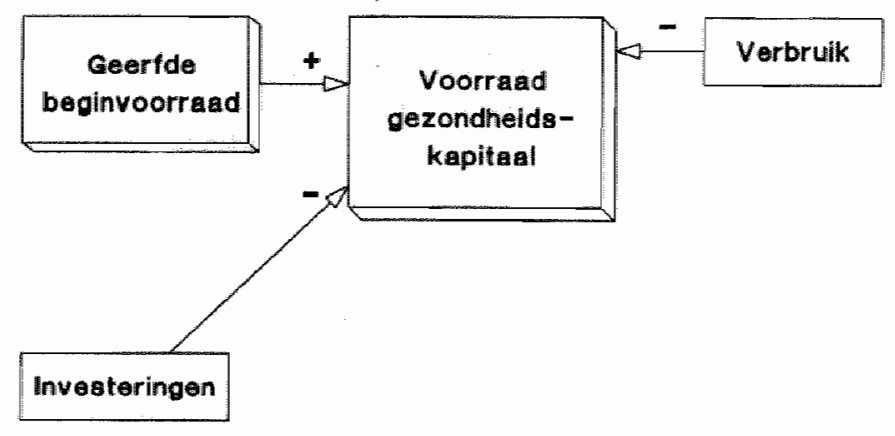

In de eerder beschreven evenwich tssituatie geldt tevens de volgende relatie:

$$
\gamma_{i}=r+\delta_{i}
$$

De rechter term van deze vergelijking drukt de totale kosten wan gezondheidskapitaal bestaande uit de gederfde alternatieve opbrengsten (rentevoet $r$ ) en de afname ervan uitgedrukt in de depreciatievoet $\left(\delta_{i}\right)$. Deze relatie impliceert bijvoorbeeld dat bij een hogere leeftijd de depreciatievoet zal toenemen $\left(\delta_{i+1}\right)$ en derhalve de investering in gezondheidskapitaal pas bij hogere marginale opbrengst renderend wordt $\left(\mathrm{H}_{\mathrm{i}+1}\right)$. Gegeven het verloop van de marginale efficiëntie-curve (ME-curve) zal dit resulteren in een lagere voorraad gezondheid. Bij een verdere toename van de leeftijd zal dit uiteindelijk leiden tot de keuze van een gezondheidsvoorraad die beneden het minimumniveau $\left(\mathrm{H}_{\min }\right)$ ligt om te blijven leven. Figuur 1.1. geeft het basismechanisme in Grossman's model weer. Op deze wijze sllagt Grossman erin het biologische proces van ouder worden te benaderen als een conventioneel economisch proces. 
Het hierboven beschreven mechanisme wil overigens niet zeggen dat bij een toename van de depreciatievoet tevens de vraag naar gezondheidszorg zal afnemen. Immers deze toename zal er ook toe leiden dat er voor de produktie van nieuwe voorraad gezondheid hogere investeringen cq. meer inputs nodig zijn. De uiteindelijke relatie tussen leeftijd en het gebruik van gezondheidszorgvoorzieningen wordt dan ook mede beïnvloed door de elasticiteit van de ME-curve, die te beschouwen is als de vraagfunctie naar gezondheidskapitaal. Indien deze inelastisch is, kleiner dan 1 (steil verloop), zal een geringe afname van de gezondheidswoorraad leiden tot een relatief grote afname in de marginale opbrengst. Hierdoor is compensatie middels nieuwe investeringen aantrekkelijk. Dit in tegenstelling bij een hoge elasticiteit (vlak verloop) van de ME-curve, waarbij eenzelfde afname in de gezondheidsvoorraad een veel geringer effect heeft op de marginale opbrengst. In deze situatie zal door de gestegen marginale kosten compensatie eerder niet meer aantrekkelijk zijn. De vraag naar medische voorzieningen zal nu minder groot zijn. Hoewel in hoofdstuk 7 nog uitgebreid wordt ingegaan op de formele afleiding van verwachte effecten van veranderingen in inkomen en opleiding in het model van Grossman worden deze hier kort besproken om de basismechanismen in zijn model te verhelderen. We beperken ons hier tot de variant van het model, waarbij de opbrengsten voornamelijk gespecificeerd zijn in extra gezonde tijd en er afgezien wordt van het directe consumptieve nut, het zogenaamde zuivere investeringsmodel. Hierna wordt het effect beschreven van een verandering in loon of opleiding. Indien de prijs van tijd, het uurloon (W), stijgt van $W_{1}$ naar $W_{2}$, zall de

Figuur 1.3. Effect van loon op de vraag naar gezondheidskapitaal (Bron: Grossman 1972b)

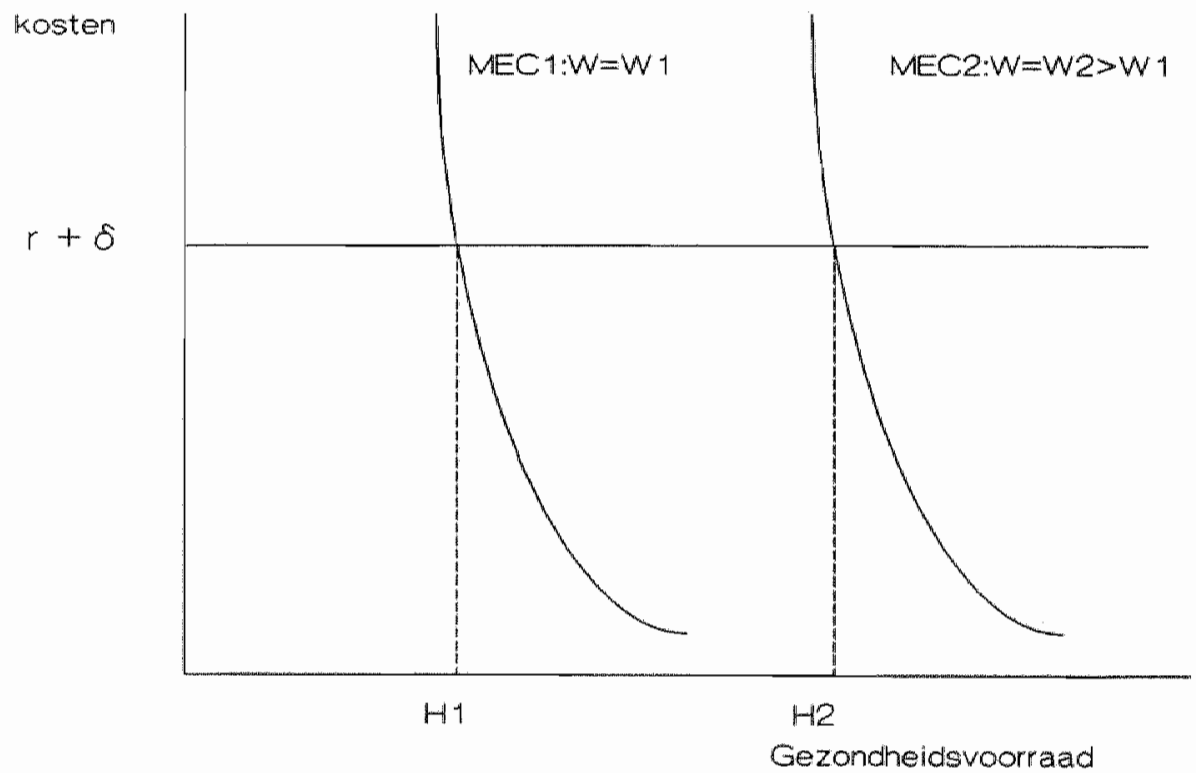


marginale opbrengst van gezondheid, gemeten in tegen loon gewaardeerde extra gezonde dagen, toenemen. De mate waarin de kosten van gezondheidskapitaal beïnvloed worden door een toename van het loon, hangt samen met het aandeel van de tijdprijscomponent in de totale inwesteringskosten van gezondheidskapitaal. Indien deze bijvoorbeeld $\mathrm{K}$ bedraagt $(\mathrm{K}<1)$ en het loon stijgt met 1\% dan zal deze kostentoename Kx $1 \%$ bedragen. Per saldo zal de marginale efficiêntie van het additionele gezondheidskapitaal met 1-K toenemen. Dit saldo zal groter dan nul zijn zolang de produktie van nieuw gezondheidszorgkapitaal niet volledig door middel van tijdinputs plaatsvindt. In al die gevallen zal er een hogere gezondheidswoorraad gekozen worden. In figuur 1.3. wordt het effect van een loonstijging weergegeven. In tegenstelling tot een toename van de depreciatievoet heeft een toename van het loon geen effect op de toename van de gezondheidswoorraad bij een gegeven input van gezondheidszorgvoorzieningen. Derhalve zal de vraag naar gezondheidszorg stijgen met de toename van het loon. Indien de verhouding van de inputs van gezondheidszorg en tijd niet zou veranderen zou de loonelasticiteit van de vraag naar gezondheidszorg gelijk zijn aan die van de gezondheidswoorraad. Echter als gevolg van de toename van de prijs van de tijdinputs zullen deze gesubstitueerd worden door aan te kopen marktgoederen, totdat de marginale opbrengst van de tijdinputs gelijk is aan het nieuwe uurloon. Naarmate dit substitutie-effect groter is zal de loonelasticiteit van de vraag naar gezondheidszorg in positieve zin meer verschillen wan de loonelasticiteit van gezondheid.

Tot slot wordt hierna nog ingegaan op het effect van opleiding.

Figuur 1.4. Effect van opleiding op de vraag naar gezondheidskapitaall. (Bron: Grossman, 1972b)

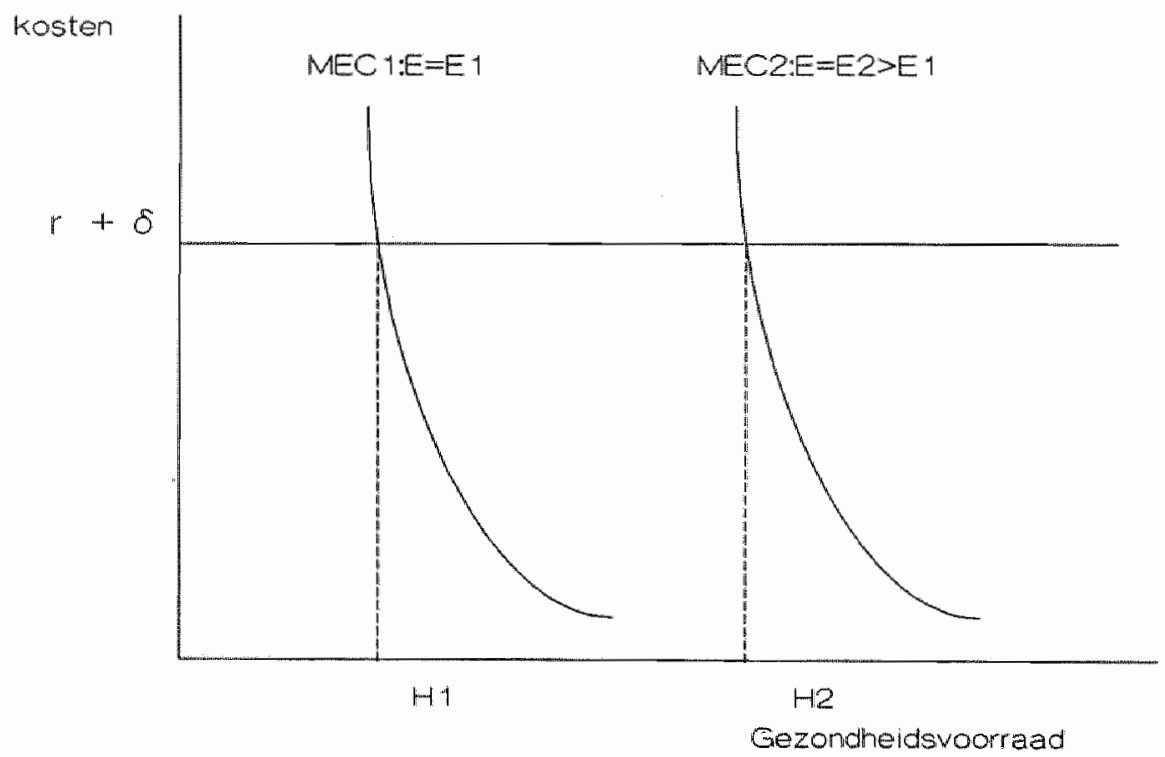


In het investeringsmodel wordt opleiding opgevat als een factor die de produktiviteit van het huishoudelijke produktieproces verhoogt. Verondersteld wordt dat een toename van de opleiding (E) de efficiëntie van dit produktieproces zal doen toenemen. Dit impliceert onder de veronderstelling, dat er sprake is van een produktiefunctie die homogeen van de eerste graad $^{1}$ is, de marginale opbrengsten van de inputs evenredig zullen toenemen met een toename van opleiding. Dit laatste betekent een afname van de benodigde kwantiteiten van deze inputs bij een gegeven produktieniveau, warardoor bij constante prijzen de gemiddelde en marginale kosten van een eenheid bruto-investering zullen afnemen. Onder conditie van een constante loonvoet en een constant marginaal produkt van een gegeven gezondheidsvoorraad zal als gevolg van een toename van het opleidingsniveau de marginale efficiëntie van gezondheidskapitaal toenemen. Figuur 1.4. geeft de consequenties voor de ME-curve en de optimale gezondheidsvoorraad weer.

Indien nu $r_{H}$ de procentuele toename in de gezondheidswoorraad weergeeft als gevolg van een toename van én eenheid opleiding en $\varepsilon$ de elasticiteit van de ME-curve weergeeft, dan kan het effect van dezelfde toename van opleiding op de vraag naar gezondheidszorg $\mathrm{M}$ als volgt worden weergegeven:

\section{$\widehat{\mathrm{M}}=\mathrm{r}_{\mathrm{H}}(\varepsilon-1) \quad \hat{\mathrm{M}}$ is de procentuele toename in $\left.\mathrm{M}\right)$}

Uit deze vergelijking blijkt dat een positieve verandering in opleiding tot een afname in de vraag naar gezondheidszorg leidt indien de elasticiteit van de ME-curve kleiner dan 1 is. Met andere woorden in een dergelijke situatie is het aantrekkelijk om een gedeelte van de toename van de gezondheidswoorraad als gevolg van de hogere produktiviteit "in te ruilen" voor een vermindering van de aan te kopen voorzieningen.

Het hierboven beschreven model kan beschouwd worden als een geslaagde poging om het gedrag van individuen inzake keuzen ten aanzien van hun eigen gezondheid en daarvan afgeleid ten aanzien van de vraag naar gezondheidszorg op te vatten als een proces waarbij men op grond van economische afwegingen tot die keuzen komt. De vernieuwing die Grossman aanbrengt in de economische verklaring van de vraag naar gezondheidszorg ligt op drie niveaus (Muurinen, 1982). Op de eerste plaats vat hij niet gezondheidszorg maar gezondheid op als het finale goed waaraan men het beoogde nut ontleent. Op de tweede plaats specificeert hij een produktiefunctie voor gezondheid, waarbij gezondheidszorg naast andere factoren, zoals voeding, sport en tijd een input vormt. De efficiency wan de inputs wordt beinvloed door een "omgevingsvariabele" als opleiding. Op de derde plaats vat hij gezondheid op als een vorm van menselijk kapitaal. Dit menselijk kapitaal ontleent zijn waarde aan de eigenschap dat het een bijdrage levert aan te werwerven inkomsten.

Ondanks dat deze benadering veel navolging heeft gekregen in empirische studies binnen hett veld van de gezondheidseconomie (zie bijvoorbeeld Van Doorslaer, 1987; Wagstaff, 1986a; Kemna, 1987; Carrin en De Graeve, 1986; Muurinen, 1982; Shakotko e.a., 1981) zijn er een aantal kritiekpunten te noemen (McGuire e.a., 1988, p. 141 e.v.). Op de eerste plaats betreft dit de veronderstelde zekerheid c.q. volledige geinformeerdheid van het individu ten aanzien van haar gezondheid. Kennis over de ontwikkeling van de depreciatievoet en de toekomstige opbrengsten van gezondheid spelen een cruciale rol in zijn model, terwijl de verwachtingen ten aanzien van deze variabelen in werkelijkheid door onzekerheid gekenmerkt worden (zie ook Van 
Doorslaer, 1987, p. 16). Op de tweede plaats veronderstelt de in het model gebruikte produktiefunctie constante opbrengsten van de produktiefactoren. Echter zoals Usher (aangehaald in McGuire e.a., 1988, p. 142) stelt moet men eerst kanker hebben, wil radiologische bestraling een eventueel positief effect op iemands gezondheid hebben. Met andere woorden, het marginale produkt van de meeste curatieve gezondheidszorg is nihil of zelfs negatief, tenzij men ziek is. Een derde kritiekpunt komt van Muurinen (1982), die vraagtekens stelt bij het onderscheid in het karakter van het finale goed gezondheid in een investerings- resp. consumptiegoed. Grossman zelf behandelt deze twee eigenschappen wan gezondheid als rivaliserend. Zo leidt zijn consumptiemodel niet tot een eénduidige voorspelling van het effect van een verandering in de loonvoet (zie ook paragraaf 7.2.). Met andere woorden de keuze voor één van de benaderingen leidt tot andere gedragsvoorspellingen, terwijl in werkelijkheid het meer voor de hand ligt dat door de consument beide opbrengsten alls gewenst worden beschouwd. Een laatste punt van kritiek dat eveneens door Murinen (1982) te berde is gebracht heeft betrekking op de wijze waarop de variabele opleiding in het model geïncorporeerd is. Deze variabele wordt verondersteld een outputverhogend effect te hebben op de directe inputs zoals gezondheidszorg. $\mathrm{Zij}$ stelt echter dat de waarschijnlijke rol van opleiding in het produktieproces ook een rol speelt in de keuze van diverse inputs bijvoorbeeld voor een gezondere levensstijl. Als gevolg hiervan zal opleiding eerder een remmend effect op de depreciatievoet hebben. Tot slot toont Wagstaff (1986a) aan dat het niet zondermeer mogelijk is om de hypothese ten aanzien van de efficiëntie bevorderende roll van opleiding te toetsen met behulp van schatting van de vraagfunctie naar gezondheid in een gereduceerde vorm. McGuire e.a. (1988, p. 144) pleiten op grond hiervan om een eventweel effect van opleiding op de huishoudproduktiefunctie analoog aan het effect van een voorkeur-variabele op te vatten. In een gereduceerde vormvergelijking ${ }^{2}$ van de vraagfunctie naar gezondheid zou opleiding dan de betekenis kunnen hebben van een dergelijke voorkeur-indicator.

In de volgende paragraaf zal aangegeven worden op welke wijze de in de vorige en deze paragraaf beschreven benaderingen een uitgangspunt zullen vormen voor de empirische analyse in deze studie.

\subsection{MODELKEUZE EN NADERE AFBAKENING VAN DE PROBLEEMSTELLING}

Hiervoor hebben we in dit hoofdstuk een overzicht gegeven van Becker's tijdallocatie-theorie en de wijze waarop deze verwerkt is in modellen die betrekking hebben op de verklaring van de vraag naar gezondheidszorg. Hierbinnen zijn een tweetal benaderingen te onderkennen. Tot de eerste behoren de modellen die overeenkomstig Acton's model gezondheidszorg zelf in de doelstellingsfunctie van de consument opnemen. De vraagfunctie naar gezondheidszorg wordt vervolgens geoptimaliseerd onder de restrictie van een inkomens- en tijdsbudget. In deze modellen functioneert de tijdprijs naast de geldprijs als een kostencomponent van gezondheidszorg.

De tweede benadering met Grossman als belangrijkste vertegenwoordiger, neemt niet gezondheidszorg, maar gezondheid in de doelstellingsfunctie op. Daarbij wordt gezondheid opgevat als een kapitaalgoed. Tijd speelt nu zowel een rol bij de kosten als bij de opbrengsten. De produktiefunctie benadering impliceert hier, dat gezondheid onder andere een functie is van gezondheidszorg en eigen tijdinputs, waarbij opleiding de effectiviteit van deze inputs verhoogt. Bij Acton functioneert tijd als een vast 
kostenelement van gezondheidszorg. Hierdoor abstraheert Acton van eventuele substitutie tussen inputs als gevolg van prijsveranderingen. De implicaties hiervan worden zichtbaar bij de gevolgen van een verhoging van de loonvoet. In Grossman's model leidt dit op de eerste plaats tot een toename van de vraag naar gezondheid, omdat de marginale opbrengsten van gezonde tijd toenemen. In de tweede plaats vindt er een substitutie van tijdinputs door gezondheidszorg plaats. Hierdoor zal de vraag naar gezondheidszorg meer toenemen dan de vraag naar gezondheid. In Acton's model ligt de tijdinput vast. Een verhoging wan de loonvoet leidt hier tot een positief inkomenseffect, en een niet eenduidig substitutie-effect. Dit laatste is negatief indien de tijdprijscomponent van gezondheidszorg groter is dan die van de overige goederen. Indien men volledig verzekerd is zal het negatieve substitutie-effect domineren en het viteindelijke effect van een verhoging van het uurloon zal dan in een afnemende vraag naar gezondheidszorg resulteren.

In dit onderzoek zal het model van Acton als uitgangspunt dienen, wanneer het gaat om het effect van tijdprijzen op de vraag naar afzonderlijke gezondheidszorgvoorzieningen te schatten. Vervolgens zullen een aantal vraagfuncties voor gezondheid geschat worden, waarbij het investeringsmodel van Grossman als theoretisch uitgangspunt dient. Hierbij ligt de nadruk op de effecten van veranderingen in tijdswaardering op het gewenste gezondheidsniveau.

De volgende overwegingen hebben een rol gespeeld om het investeringsmodel van Grossman niet als uitgangspunt voor de verklaring van medische consumptie te kiezen. Hantering van dit model als uitgangspunt bij de verklaring van de vraag naar afzonderlijke voorzieningen is slechts zinvol als men in staat is middels een produktiefunctie de produktie-elasticiteiten van alle relevante inputs te schatten. Dit vereist gegevens over hoeveelheden en kosten van alle relevante inputs gedurende een langere periode (bijvoorbeeld 1 jaar). Deze gegevens zijn in het algemeen voor de Nederlandse situatie niet beschikbaar. Een alternatief zou zijn om de diverse vormen van medische consumptie als een homogeen pakket van inputs te beschouwen en hiervoor éen vraagfunctie te schatten. Afgezien van het genoemde probleem van ontbrekende data is dit een vergaande vereenvoudiging van de werkelijkheid. Dan nog blijft het probleem bestaan dat er geen gegevensbestanden beschikbaar zijn waarin én gegevens over medische consumptie zijn opgenomen én gegevens over andere inputs als gezonde voeding, sport enz. Bij schatting van aparte vraagfuncties voor specifieke vormen van medische consumptic wordt meer recht gedaan aan de eigen karakteristieken van de betreffende consumptiecategorie. Er worden dan ook uiteenlopende tijdprijselasticiteiten voor de verschillende vormen van medische consumptie verwacht.

De keuze voor het model van Acton als theoretisch kader bij de verklaring van de vraag naar afzonderlijke gezondheidszorgvoorzieningen impliceert de veronderstelling dat het gebruik hiervan voor de consument een op zichzelf staand nut heeft en dat tijdprijzen als exogene verwervingskosten beschouwd worden.

Hieronder vindt een nadere afbakening van de vraagstellingen van deze studie plaats.

In dit onderzoek wordt voor de Nederlandse situatie nagegaan of en in welke mate er sprake is van tijdprijseffecten op het gebruik van een viertal vormen van medische consumptie. 
Deze vier vormen van medische consumptie zijn:

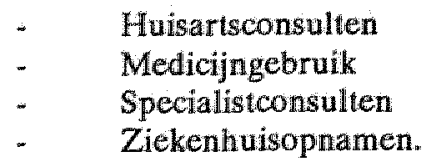

Op basis van het theoretische model van Acton worden in dit onderzoek de volgende predicties getoetst:

de tijdprijs functioneert als een prijs, hetgeen impliceert dat negatieve elasticiteiten met betrekking tot medische consumptie worden werwacht. indien tijdprijzen functioneren als een kruisprijs wordt een positief effect op medische consumptie verwacht woor zover deze kruisprijs betrekking heeft op een voorziening die als substituut functioneert, en een negatief effect voor zover er sprake is van een complementaire voorziening.

Daarnaast wordt op basis van het investeringsmodel van Grossman getoetst of en in welke mate de tijdswaardering van invloed is op de individuele gezondheidswoorraad respectievelijk de produktie van "gezonde tijd". Het hierboven geschetste probleem van ontbrekende gegevens over alle inputs wordt hierbij overwonnen door deze vraagfunctie naar gezondheid te schatten in haar gereduceerde vorm². Hierbij zijn immers alleen gegevens vereist over prijzen, inkomens en opleiding.

Vervolgens wordt in deze studlie een poging gedaan een antwoord te vinden op de vraag wat de verhouding van de tijdprijskosten tot de directe kosten van de genoemde vormen van medische consumptie is en in welke mate de directe kosten van gezondheidszorg op macro-niveau beïnvloed worden door een verandering in de tijdprijzen.

Specificatie en schatting van de vraagfuncties voor de vier genoemde vormen van medische consumptie vindt respectievelijk plaats in de hoofdstukken $3,4,5$ en 6 . Specificatie en schatting van de vraagfuncties naar gezondheid vindt plaats in hoofdstuk 7. De calculaties ten behoeve van de omvang van de kosteneffecten op macro-niveau worden in hoofdstuk 8 gepresenteerd. Tot slot worden in hoofdstuk 9 de belangrijkste bevindingen van deze studie nog eens samengevat.

Noten

1) Een produktiefunctie is homogeen van de eerste graad indien een toename van de produktiefactoren met een bepaald percentage leidt tot een toename van de produktie met eenzelfde percentage.

2) In de gereduceerde vorm vam een model is elke endogene variabele afzonderlijk uitgedrukt in alleen exogene variabelen. In wiskundige termen betekent dit dat een stelsel van meerdere vergellikingen met meerdere onbekende opgelost wordt door de onbekende (endogene) variabelen te beschrijven als een functie van bekende (exogene) variabelen (Goris, 1972, p. 7). 
"Il est malheureusement bien vrai qua, sans le loisir... l'amour ne peut être qu'une orgie de roturier que l'accomplissement d'un devoir conjugal. Au lieu du caprice brülant ou rêveur, il devient une répugnante urilitét". (Baudelaire, 1925).

\subsection{INLEIDING}

De aan het eind van het vorige hoofdstuk genoemde vraagstelling zal beantwoord worden met behulp van een dwarsdoorsnede-analyse, waarbij de variatie in medische consumptie tussen individuen verklaard wordt. In dit hoofdstuk worden een aantal methodische aspecten van het empirische gedeelte van deze studie behandeld. In paragraaf 2.2. zullen de data worden beschreven en zal er worden ingegaan op de representativiteit van de onderzoekspopulatie. De te verklaren consumptiecategorieën en de algemene modelopbouw worden in paragraaf 2.3. besproken. In paragraaf 2.4 . wordt ingegaan op de wijze waarop de diverse variabelen geoperationaliseerd worden. Paragraaf 2.5 . behandelt de gebruikte schattingstechniek.

\subsection{DE DATA}

In dit onderzoek wordt gebruik gemaakt van de Gezondheidsenquête van het Centraal Bureau voor de Statistiek (CBS). Het betreft een continue enquête die erop gericht is

*) Het is maar al te waar dat zonder vrije tijd... de liefde niet in staat is zich te verheffen boven de orgie van de burgerman of boven het vervullen van de huwelijksplicht. In plaats van een hartstochtelijke of dichterlijke vlam wordt ze een weerzinwekkend gebruiksgoed. 
een zo volledig mogelijk overzicht te geven van de ontwikkelingen in de gezondheid en de medische consumptie van de gehele Nederlandse bevolking (Appelboom, 1982b). Deze enquete wordt vanaf 1981 gehouden en heeft een belangrijk voordeel ten opzichte van bijwoorbeeld de registraties die middels het Landelijk Informatiesysteem Ziekenfondsen (LISZ) en de Stichting Medische Registratie (SMR) plaatsvinden. Dit voordeel is dat de Gezondheidsenquete in tegenstelling tot de genoemde registraties naast gegevens betreffende het gebruik van medische voorzieningen, diverse achtergrondvariabelen bevat die van invloed kunnen worden geacht op de medische consumptie. Hierbij kan worden gedacht aan variabelen als leeftijd, geslacht, opleiding, verzekeringsworm, inkomen, werksituatie enz. Daarnaast zijn in dit bestand omgevingsvariabelen opgenomen als huishoudsituatie, de urbanisatiegraad van de regio enz. Tot slot is er in de enquete gevraagd naar de reis-, wacht- en behandeltijd bij een bezoek aan de huisarts.

Tot de doelpopulatie van de Gezondheidsenquête behoort de totale Nederlandse bevolking, voor zover niet verblijvend in inrichtingen en tehuizen en woor zover niet behorende tot de rijdende en varende bevolking. Dit houdt onder meer in dat personen die zijn opgenomen in een zilekenhuis of verpleegtehuis niet in de steekproefpopulatie zijn opgenomen.

Als waarnemingseenheid bij de Gezondheidsenquête is gekozen voor personen en huishoudens. De steekproef wordt a-select in 2 trappen getrokken. De eerste trap is een steekproef uit alle gemeenten in Nederland, de tweede trap bestaat uit een steekproef van woonadressen in iedere getrokken gemeente. Uiteindelijk worden alle huishoudens op ến adres en binnen elk huishouden alle personen geënquêteerd. In dit onderzoek zal de analyse voornamelijk gebaseerd zijn op gegevens van individuen waarbij kenmerken van het huishouden als achtergrondvariabelen worden meegenomen.

De Gezondheidsenquete 1981 bevat uiteindelijk de gegevens van 10.218 personen uit circa 3.500 huishoudens. De respons voor deze enquête lag op 68\% (v.d. Berg, 1983). De respons blijkt naar leeftijd en geslacht een redelijk afspiegeling van de Nederlandse bevolking te zijn met dien verstande dat jongeren tot 19 jaar iets oververtegenwoordigd zijn en ouderen boven de 65 jaar iets ondervertegenwoordigd (Appelboom, 1982b). In tabel 2.1. wordt de representativiteit met betrekking tot een aantal andere persoonskenmerken vergeleken. Hieruit blijkt dat op basis van de geslachtsverdeling, burgerlijke staat, plaats in het huishouden, percentage werkenden en zelfstandigen en zelfstandigen en medewerkende gezinsleden de enquête-populaties een redelijke afspiegeling van de Nederlandse bevolking vormen. Daarnaast blijkt dat buitenlanders en personen wonend in stedelijke gemeenten zijn ondervertegenwoordigd.

In tabel 2.2. wordt het bestand van de Gezondheidsenquête vergeleken op basis van de verzekeringsvorm. Hieruit blijkt dat de groep ziekenfondsverzekerden enigzins is oververtegenwoordigd. 


\section{Tabel 21. Representativiteht mot betrekking tot diversei persoonskenmerken van het GE81-bestand voor de Nederlendse bevolking}

\begin{tabular}{lll}
\hline & Nederlandse & GE81, 10.218 \\
bevolking in & 1981 personen
\end{tabular}

\section{Geslacht}

vrouwen

\section{Burgerlijke staat}

ongehumid

gehumid

weduws taat

gescheiden

Nationaliteit buitentandse

\section{Plaats in huishouden ${ }^{2}$}

al leenstaand

hoofd v.h. huishouden

echtgenate v.h. hoofd huishouden

kinderen v.h. hoofd huishouden

rest (niet vergelijkbaar)

Werk

weirkenden

Beraep (in \% v.d. beroepsbevolking)

zelfstandige en medewerkende

gezinsleden

\section{Urbanisatiegraad V.d. moonplaats}

plat telandsgemeenten

geîndustr. plat telandsgemeenten

specifieke forensengemeenten

stedelijke gemeenten $<100.000$ inw.

stedelijke gemeenten $>100.000 \mathrm{inw}$.

\section{Grootte W.h. huishouden}

1 persoon
2 personen
3 personen
4 personen
5 personen
$>6$ personen

Soort praktlik v.d, huisarts ${ }^{3)}$

individuele praktijk

Huisarts ${ }^{3)}$

apotheekhoudend
$50.4 \%$

$49.7 \%$

43.9

48.3

4.5

2.4

43.5

50.6

4.2

1.7

$3.7 \quad 2.0$

5.3

5.7

26.5

23.4

41.2

28.4

25.5

38.5

$\begin{array}{ll}3.6 & 1.8\end{array}$

36.5

37.2

11.4

13.8

11.6

13.2

22.4

24.8

14.2

15.1

27.8

19.1

24.9

17.9

16.9

30.2

30.8

16.8

15.5

20.9

23.8

8.9

8.8

5.4

4.3

66.9

70.1

23.9

24.5

1) De gegevens over de Mederlandse bevolking zijn meerendeels afkonstig wit de Statistische Zakboeken van het CBS van 1981 en 1982.

2) Vergelijkingsmateriaal voor de gegevens over de plaats in het huishouden is afkomstig van de Volkstelling vani 1971.

3) Vergetijkingsmateriaal voor de gegevens over de praktijkvorm $z i j n$ afkomstig van het Nederlands Huisartsen Insti tuut.

Bron: Van Vliet en v.d. Ven (1984). 


\begin{tabular}{|c|c|c|c|c|c|}
\hline & \multicolumn{2}{|c|}{$\begin{array}{l}\text { Ned. bevolking } \\
\text { in } 1981\end{array}$} & & \multicolumn{2}{|c|}{$\begin{array}{l}\text { GE81, } 10.218 \\
\text { personen }\end{array}$} \\
\hline & 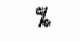 & warvan & & w & warvan \\
\hline Zlekenfondsverzeker ing ${ }^{1 .}$ & 67.9 & $100 \%$ & 69.3 & $100 \%$ & \\
\hline verplichte verzekering & & 72.8 & & 73.9 & \\
\hline vrijwillige verzekering & & 16.0 & & 18.7 & \\
\hline bejaarden verzekering & & 11.1 & & & 8.3 \\
\hline \multicolumn{6}{|l|}{ Particullere verzekering ${ }^{2}$} \\
\hline Privaatrechteliik & 26.0 & $100 \%$ & 24.7 & $100 \%$ & \\
\hline voor ziekenhuiskosten & & 99.6 & & 100.0 & \\
\hline voor polikl.specialistische hulp & & 96.6 & & 99.3 & \\
\hline voor medicijinen op recpet v.d. spec. & & 88.8 & & 94.5 & \\
\hline voor huisartsenhulp & & 61 & & 62.2 & \\
\hline voor medicijnen op recept v.d. huisart & & 61 & & 64.0 & \\
\hline Publiekrechtelijk (Ambtenarenverzekering & & 5.9 & & 6.0 & \\
\hline Totaal & & $100 \%$ & $100 \%$ & - & \\
\hline
\end{tabular}

$1)$ De gegevens over de (Nederlandse) ziekenfonds verzekerden zijn afkomstig uit thet jaarboek van 1981 van het Landelijk Informatie Systeem Ziekenfondsen (LISZ).

2) De percentagens particulier verzekerden die voor de diverse categorieën van medische zorg (gedeeltelijk) verzekerd $z i j n$ berekend uit gegevens van het KISG.

Bron: Wan Wliet en Van de Ven (1984).

Binnen deze groep zijn de vrijwillige verzekerden owervertegenwoordigd en degenen die vallen onder de bejaardenverzekering ondervertegenwoordigd. De verdeling van de particulier verzekerden over de privaatrechtelijke en de publiekrechtelijke verzekeringsworm komt goed overeen met landelijke gegevens. Tot zover enige opmerkingen ten aanzien van de representativiteit van de Gezondheidsenquête.

In deze studie vinden de analyses naar tijdprijseffecten plaats op de gegevens van deelpopulaties. De deelpopulaties zijn in alle gevallen geselecteerd op basis van het criterium leeftijd (ouder dan 15 en jonger dan 65 jaar) en in sommige gevallen op basis van het criterium inkomen uit arbeid (winst, salaris, loon of een combinatie hiervan). Daar er bij de analyses alleen die respondenten worden meegenomen waarvan de gegevens van de variabelen die deel uitmaken van de analyse complleet aanwezig zijn, is het wan belang om na te gaan of er als gevolg van partiële non-respons alsnog de representativiteit bedreigd wordt. Met name op de inkomensvragen is de partiële non-respons vrij hoog (ca. 20\%). Van Sonsbeek en Stronkhorst (1983) die een uitwoerige analyse gemaakt hebben van de eventuele systematische samenhang tussen partiële non-respons en bepaalde achtergrondkenmerken concluderen dat ten aanzien 
wan de non-respons op de inkomensvragen er geen duidelijke samenluang is met de hoogte van het inkomen. De leeftijd van de respondent blijkt de belangrijkste verklarende variabele te zijn voor de in totaliteit optredende partiele non-respons. Echter ook deze variabele draagt slechts $3 \%$ bij aan de verklaring van de partiele non-respons. Op grond van het bovenstaande is het aannemelijk te veronderstellen dat ook de in deze studie gebruikte deelpopulaties representatief zijn voor dat deel van de Nederlandse bevolking dat voldoet aan dezelfde selectiecriteria.

Ten aanzien van de betrouwbaarhelid van de in deze studie gebruikte gegevens over medische consumptie dient het volgende nog opgemerkt te worden. Als gevolg van het feit dat deze gegevens over een langere periode gevraagd worden, variërend van 14 dagen tot een jaar, treden hierbij herinneringseffecten op. Uit dezelfde studie wan Van Sonsbeek en Stronkhorst (1983) blijkt dat bij rapportage van huisartscontact over 3 maanden $30 \%$ van deze contacten vergeten wordt. Voor contacten met specialisten bedraagt dit vergeetpercentage $19 \%$. Ten aanzien van de opnamekans in het ziekenhuis is er eweneens sprake van een onderrapportage. Het aantal opnamen per 100 personen ligt in de Gezondheidsenquête op 8,3 terwijl op basis van landelijke registratie (Centraal Bureau voor de Statistiek e.a., 1981) er 11,4 opnamen per 100 personen plaatsvinden. De oorzaak hiervan ligt niet zozeer in herinneringseffecten dan wel in een van de volgende omstandigheden (Van Brekel, 1985b):

in de Gezondheidsenquête worden geen ziekenhuisopnamen in verband mel bevalling geregistreerd

opnamen van personen die in het ziekenhuis overleden zijn worden niet geregistreerd

opnamen van personen die aansluitend in een verpleeghuis of in een andere inrichting langdurig zijn opgenomen worden in de enquête niet meegenomen.

Daarnaast zullen ook bij deze variabelen vergeeteffecten optreden.

Een laatste gegeven dat relevant is voor een beoordeling van de gegevens is een eventueel effect van vervangende enquêtes of zgn. proxy-interviews. Indien een lid van het huishouden niet aanwezig is worden de gegevens door een ander lid van dat huishouden verstrekt. In het onderzoek van Van Sonsbeek en Stronkhorst (1983) concluderen de auteurs dat de gemiddeld lagere medische consumptie bij proxy-interviews geheel te wijten is aan de specifieke selectie die optreedt. Proxy-interviews doen zich vooral woor bij jongere leeftijdsgroepen (15-24 jaar) en meer bij mannen dan bij vrouwen. $Z$ ij vinden geen aanwijzingen dat het proxy-interview op zichzelf tot een onderrapportage zou leiden.

Samenvattend kan gesteld worden dat er ten aanzien van de representativiteit van de gebruikte deelpopulatie er geen directe aanleiding is om deze niet als een redelijk betrouwbare afspiegeling van dat deel van de Nederlandse bevolking te beschouwen, dat voldoet aan de genoemde criteria. Vervolgens dient vastgesteld te worden dat met name bij medische consumptie er sprake is van onderrapportage. Er is echter geen aanleiding te veronderstellen dat deze onderrapportage op een systematische wijze zou samenhangen met bepaalde individuele karakteristieken. Daar het bestaan van exn eventuele samenhang ook niet is vast te stellen, ligt hier wel een zekere beperking van de gebruikte gegevens. Voor het selectie-effect dat optreedt als gevolg van vervangende 
interviews kan grotendeels gecorrigeerd worden met behulp van de variabelen leeftijd en geslacht.

\subsection{CONSUMPTIECATEGORIEEN EN MODELOPBOUW}

In deze studie worden een viertal basismodellen geschat die respectievelijk betrekking hebben op huisartsconsulten, medicijngebruik, specialistconsulten en ziekenhuisopnamen. Deze vier consumptiecategorieën zijn niet geheel onafhankelijk van elkaar en er is tevens sprake van een zekere hiërarchie. In onderstaand schema dat geinspireerd is door het structuurmodel van Rutten (1978) wordt deze samenhang weergegeven. Dit schema is specifiek voor de Nederlandse situatie in het begin van de jaren tachtig.

Figuur 2.1. Gebruik medische voorzleningen in een jaar.

(Percentage van de Nederlandse bevolking)

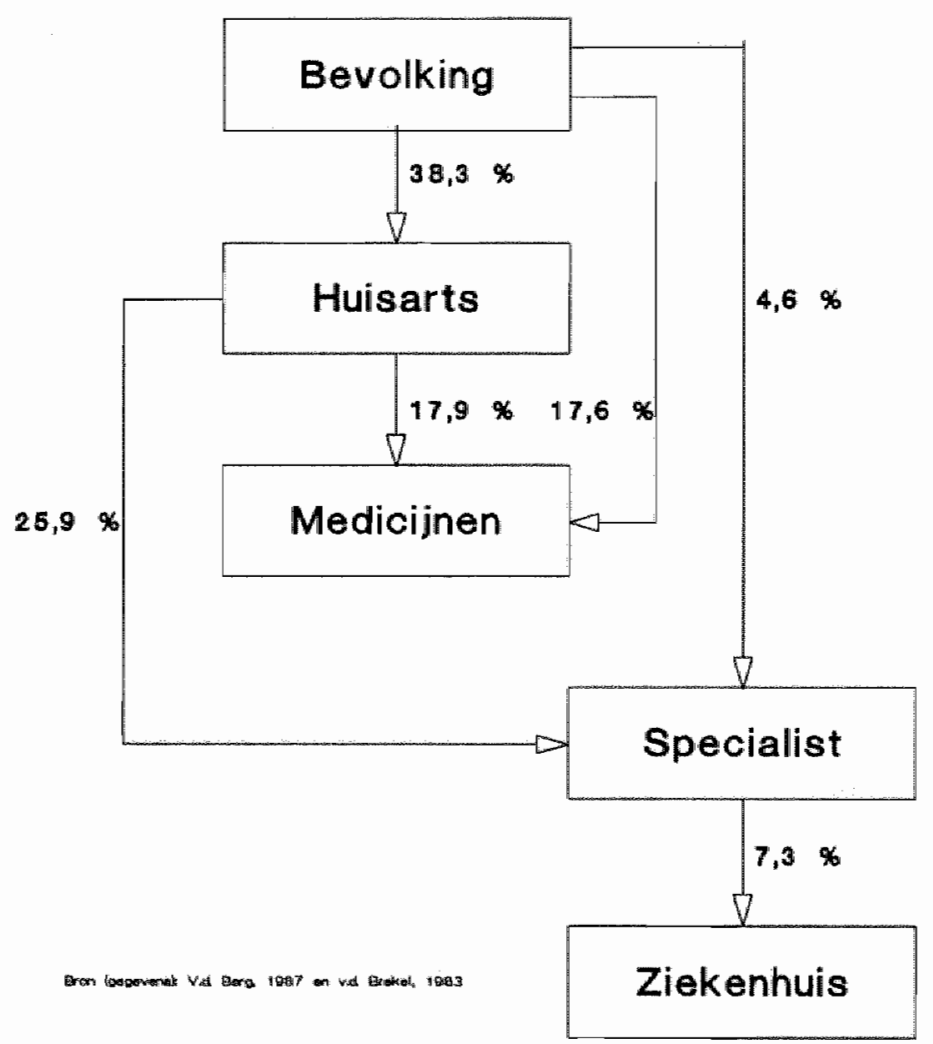


De toegang tot het gezondheidszorgsysteem loopt meestal via de huisarts. Aan het contact met de specialist gaat over het algemeen een contact met de huisarts vooraf. Medicijnen op recept worden verkregen na contact met de huisarts of specialist. Aan een opname in het ziekenhuis gaat in de meeste gevallen een contact met de specialist vooraf. In acute gevallen kan een patiënt echter direct in cen ziekenhuis worden opgenomen. Daarnaast kunnen particulier verzekerden in sommige gevallen direct bij een specialist terecht, terwijl ziekenfonds verzekerden in alle gevallen een verwijzing van de huisarts nodig hebben.

Dit laatste heeft tot gevolg dat voor ziekenfondsverzekerden een huisartscontact complementair is aan een eerste specialistcontact. Bij particulier verzekerden kan, afhankelijk van de verzekeringsvoorwaarden, deze als een complement dan wel als een substituut functioneren. In het laatste geval is het specialistcontact een substituut voor een contact met de huisarts. Bij de beschrijving van de afzonderlijke schattingsmodellen en de interpretatie van de resultaten in de volgende hoofdstukken wordt hier nog op terug gekomen. In samenhang met het bovenstaande is een ander onderscheid van belang, te weten of het consult geinitieerd is door de patient of door de arts. Feldstein (1974) hanteert op grond hiervan een indeling in drie typen zorg:

I zorg op initiatief van de patiënt

II zorg op initiatief van de ene arts verleend door de andere arts

III zorg op initiatief van de arts zelf.

Het onderscheid tussen de door de patiënt en de arts geïnitieerde vraag is in economische vraaganalyses daarom van cruciaal belang, omdat deze erop gericht zijn wijzigingen in het keuze-gedrag van de consument te woorspellen indien deze geconfronteerd wordt met veranderingen in prijzen of inkomens. Stoddart en Barer (1981) stellen dat gegevens met betrekking tot het gebruik van woorzieningen niet adequaat zijn om een vraagfunctie te schatten, tenzij men aanneemt dat de arts als perfecte vertegenwoordiger van de voorkeuren van de patiënt optreedt. Binnen de gezondheidseconomie is onderzoek naar de omvang van de zogenaamde aanbod geĩnduceerde vraag een belangrijk thema geworden. Aanbod-geïnduceerde vraag houdt in dat het feitelijk gebruik van voorzieningen op een hoger niveau ligt dan het niveau dat gerealiseerd zou zijn indien er sprake was van een volledig geînformeerde consument, die strikt op basis van eigen voorkeuren tot keuzen komt (Mooney en McGuire, 1988). Feldstein (1983) stelt dat het de duale rol van de arts is, zowel deskundig adviseur als aanbieder van zorg, die het hem mogelijk maakt eigen belangen te realiseren middels beïnvloeding van de consument. Eén van deze belangen van de arts is gelegen in realissering van een zeker inkomensniveau. Deze veronderstelling ten aanzien van artsengedrag staat bekend als de "target-income hypothesis". De observatie dat het gebruik per hoofd van dle bevolking positief samenhangt met de artsendichtheid lijkt deze hypothese te bevestigen. Enthoven (1981), Feldstein (1983) en Mooney en McGuire (1988) geven overzichten van empirische analyses, waarin deze positieve samenhang bevestigd wordt.

In deze studie waarim het keuze-gedrag van de consument centraal staat, wordt de benadering van Rossiter en Wilensky (1983) gevolgd om een eventueel effect van aanbod op de vraag te "isoleren". Zij maken, vergelijkbaar met het hiervoor besproken onderscheid van Feldstein, verschil in door patiënt of arts geïnitieerde vraag. Zij specificeren en schatten voor elk type vraag aparte vraagfuncties. Het achterliggende 
idee is dat de patiênt-geïniticerde vraag voornamelijk een functie is van patiëntgebonden variabelen. De door de arts geïnitieerde vraag zal mede samenhangen met kenmerken van de aanbodzijde, zoals de artsendichtheid.

In dit onderzoek zullen indien de data dit toestaan aparte modellen geschat worden voor de door de patiēnt geïnitieerde vraag en door de arts geïnitieerde vraag. In de laatste modellen zullen variabelen worden opgenomen die een indicatie zijn voor het niveau van het aanbod. Op deze wijze wordt er gecorrigeerd voor een eventueel aanbodeffect op medische consumptie. Deze wijze van correctie voor aanbodeffecten is overigens voor kritiek vatbaar. Hierop wordt teruggekomen bij de bespreking van de afzonderlijke modelvariabelen verderop in dit hoofdstuk. Tevens is de verwachting dat persoonlijke achtergrondvariabelen in de door de arts geïnitieerde vraag een minder sterke rol spelen dan bij de door de patient geinitieerde vraag. In dit onderzoek zal deze verwachting met name voor de tijdprijs getoetst worden.

Met betrekking tot de vraag naar gezondheidszorgvoorzieningen zullen de volgende modellen geschat worden (typering op basis van de te verklaren variabele):

Model I

Model II de kans op minstens een huisartsconsult gedurende een periode van

de kans op minstens een huisartsconsult gedurende een periode van 3 maanden op initiatief van de patiënt. 3 maanden niet op initiatief van de patiënt. Deze consulten hebben over het algemeen betrekking op een eerder afgesproken herhalingsconsult of op een doorverwijzing door een andere arts of specialist.

Model III de kans op gebruik van minstens één medicijn op recept gedurende een periode van 14 dagen. Hierbij wordt verondersteld dat aan dit gebruik een consult met de huisarts vooraf ging.

Model IV de kans op gebruik van minstens eén medicijn niet op recept gedurende een periode van 14 dagen. De tijdprijs voor een huisartsconsult functioneert in dit model als een kruisprijs met een verwacht positief effect.

Model V de kans op een specialistconsult op eigen initiatief gedurende 3 maanden.

Model VI de kans op een herhalingsconsult met de specialist gedurende 3 maanden.

Model VII de kans op een opname in het ziekenhuis gedurende 1 jaar.

Model VIII de duur van de opname, in het geval men opgenomen is geweest.

De modellen I en III hebben betrekking op door de patiënt geïnitieerde consumptie. De modellen II, IV en VI hebben betrekking op door de arts geïnitieerde medische consumptie. Voor de modellen V, VII en VIII is dit onderscheid minder eenduidig vast te stellen. In hoofdstuk 5 en 6 wordt hier op teruggekomen. Met betrekking tot de vraag naar gezondheid zullen een drietal modellen geschat worden:

Model IX

Model X de kans dat de respondent een gezondheid heeft die door hemzelf als goed wordt beoordeeld.

de kans dat de respondent in een periode van 14 dagen geen enkele dag had met belemmering in activiteiten als gevolg van ziekte. 
het aantal dagen dat de respondent geen belemmering in activiteiten ondervond, gegeven dat er sprake was van minstens eén dag met belemmering in activiteiten gedurende de afgelopen 14 dagen

De algemene vorm van de functies die respectievelijk de patiènt geinitieerde en de arts geinitieerde vraag beschrijven zien er als volgt uit (Rossiter en Wilensky, 1983):

$$
\begin{aligned}
& Y_{p}=f_{1}(w t, p, I, X) \\
& Y_{a}=f_{2}(w t, p, I, A, X)
\end{aligned}
$$

In beide functies zijn de economische variabelen expliciet opgenomen. Deze variabelen zijn de tijdprijs (wt), de geldprijs (p), het inkomen (I). In de vergelijking voor arts geïnitieerde vraag worden karakteristieken van het aanbod opgenomen (A), zoals artsendichtheid en/of beddendichtheid. $X$ staat voor een vector van alle overige variabelen die geacht kunnen worden van invloed te zijn op de medische consumptie en die binnen de economische theorie samengevat worden als variabelen, die de voorkeur ("taste") van de consument uitdrukken.

In de volgende paragraaf wordt beschreven op welke wijze deze variabelen in de schattingsmodellen geoperationaliseerd zijn.

\subsection{DE VERKLARENDE VARIABELEN}

In deze paragraaf worden de wijzen van operationalisatie van de verklarende variabelen alsook de verwachte richting van de effecten besproken. Hierbij beperken we ons tot de modellen waarin medische consumptie verklaard wordt. In hoofdstuk 7 wordt afzonderlijk teruggekomen op de verklarende variabelen, die in de modellen voor de vraag naar gezondheid zijn opgenomen.

\section{De tijdprijs}

De tijdprijs van medische consumptie bestat uit een volume component (de benodigde tijd) en een prijscomponent. Deze prijscomponent is de (geldelijke) waardering van een tijdseenheid. Voor een huisartsbezoek is de benodigde tijd (uit en thuis) in de Gezondheidsenquête gevraagd. Voor een contact met de specialist wordt de benodigde tijd benaderd met de afstand tot het dichtsbijzijnde ziekenhuis. Hierbij wordt gebruik gemaakt van een data-bestand van het Centrum voor Onderzock van de Economie van de Publieke Sector (COEPS), waarin met behulp van de postcodes de afstand tot het dichtsbijzijnde ziekenhuis is gemeten. Bij opname in het ziekenhuis is de benodigde tijd benaderd door middel van het gemiddelde verlies aan gewerkte uren per verpleegdag.

In dit onderzoek zal op twee manieren de waardering van de benodigde tijd geoperationaliseerd worden. In eerste instantie vindt deze plaats door de schaduwprijs hiervan te berekenen op basis van de loonvoet. De loonvoet is gelijk aan het inkomen per tijdseenheid. Dit is berekend met behulp van het bruto jaarinkomen en de gemiddelde duur van een werkweek. In hoofdstuk 1 zijn studies van Sharp (1981) en Leibowitz (1984) aangehaald waarin deze vraagtekens stellen bij deze geconstrueerde objectieve waardering van tijd. Om rekening te houden met subjectieve waarderingen, 
die moeilijk in geld te waarderen zijn, zal er in navolging van Cauley van alle modellen tevens een variant gespecificeerd worden waarbij de benodigde tijd gewaardeerd wordt middels een aantal dummy-variabelen die betrekking hebben op de alternatieve tijdsbesteding van individuen. Met behulp van deze interactieve dummy-variabelen kunnen er voor afzonderlijke tijdbestedingsgroepen tijdselasticiteiten berekend worden. Een bijkomend voordeel van deze benadering is dat de analyse niet beperkt hoeft te worden tot de indiwiduen waarvan een individueel inkomen bekend is. De eventuele variaties in de te berekenen elasticiteiten brengt een verschil in tijdswaardering tot uitdrukking die op deze wijze gemeten wordt via feitelijk gedrag van de consument. Dit komt overeen met de derde methode die Bruzelius onderscheild om tijdswaardering te meten (zie par. 1.3).

Er zullen binnen de onderzoekspopulatie de volgende zes tijdbestedingsgroepen onderscheiden worden:

1. Individuen die momenteel minstens 40 uur per week werkzaam zijn als loonof salaristrekkend (full-time loontrekkers).

2. Individuen die minstens 40 uur per week werkzaam zijn als directeur, medewerkende in gezins- of familliebedrijf, zelfstandig werkend voor eigen rekening of op freelance basis (directeuren en zelfstandigen).

3. Individuen die geen betaalde werkkring hebben en die volledig werkzaam zijn in eigen huishouding, waarbij in de betreffende huishouding minstens én kind aanwezig is (huisvrouwen met kind).

4. Individuen die een dagopleiding volgen (scholieren en studenten).

5. Individuen die een WAO-, AAW-, werkloosheids-, bijstandsuitkering genieten of een combinatie hiervan, en geen betaald werk verrichten (niet-actieven).

6. Individuen die niet tot een van de hiervoor genoemde groepen behoren. Dit zijn voornamelijke individuen met een part-time dienstverband of inidviduen die werkzaam zijn in een huishouden zonder kinderen (restgroep).

Tussen haakjes staan de typeringen die in het vervolg voor de betreffende tijdbestedingsgroep gehanteerd zullen worden.

De indeling in 6 groepen is uitsluitend, dat wil zeggen een individu is slechts bij eén van deze groepen ingedeeld. Deze indeling sluit in grote lijnen aan bij de indeling in zogenaamde "hoofdbezigheden" die men gewoonlijk bij tijdbestedingsonderzoek hanteerd (Knulst en Schoonderwoerd, 1983, p. 130). Daarnaast liggen aan deze indeling eveneens criteria ten grondslag waarvan wordt aangenomen dat deze invloed hebben op de schaduwprijs van tijd, die besteed wordt aan andere bezigheden (bijwoorbeeld medische consumptie) dan de hoofdbezigheid. Van de aanvullende criteria van "minstens 40 uur werkzaam" bij de groepen 1 en 2 en de zorg voor minstens eén kind bij groep 3 wordt een positieve invloed op de tijdswaardering verwacht. Vervolgens wordt op basis van het criterium "de mate waarin de hoofdbezigheid persoonsgebonden zijn" binnen de beroepsmatig actieven onderscheid gemaakt tussen groep 1 en 2 . Verondersteld wordt dat dit criterium sterker aanwezig is bij groep 2 dan bij groep 1 . Op grond hiervan wordt derhalve bij groep 2 een hogere tijdswaardering dan bij groep 1 verwacht. Daar dit criterium eveneens van toepassing is op de hoofdbezigheid van de groepen 3 en 4 en cen deel van 6 wordt hier eveneens een relatief hogere tijdswaardering verwacht. Het bovenstaande leidt tot de verwachting dat de tijdswaardering voor de groep "niet actieven" relatief lager ligt. In de schattingsmodellen zal de groep "directeuren en 
zelfstandigen" steeds als referentiegroep functioneren. Dit wordt in de modellen vorm gegeven door voor deze groep geen interactieve dummy-variabele voor de benodigde tijd voor medische consumptie op te nemen en woor alle andere tijdbestedingsgroepen wel. In onderstaande vergelijking waarin $Y$ voor de te verklaren medische consumptie staat,

$Y=\alpha+B_{2} T_{j}+B_{1} T_{j} D_{1}+B_{3} T_{j} D_{3}+\ldots B_{6} T_{j} D_{6}+\phi X_{i}$

$\alpha$ de constante term is, $T_{j}$ voor de benodigde tijd staat en $X_{i}$ een vector is voor de overige verklarende variabelen, zijn $\mathrm{D}_{1}, \mathrm{D}_{3} \ldots \mathrm{D}_{6}$ dummy-variabelen die gerelateerd zijn aan het behoren tot een bepaalde tijdbestedingsgroep. De dummy-variabele $D_{1}$ heeft de waarde 1 indien het betreffende individu tot tijdbestedingsgroep 1 behoort en in alle overige gevallen de waarde 0 . De dummy-variabele $D_{3}$ heeft de waarde 1 indien het betreffende individu tot tijdbestedingsgroep 3 behoort enz.

Tabel 2.3. Overzicht van coëficiènten die het effect van benodigde tijd per tijdbestedingsgroep weergegeven

Tijdbestedingsgroep

Coëfficiënten

$\begin{array}{ll}1 & B_{2}+B_{1} \\ 2^{*} & B_{2} \\ 3 & B_{2}+B_{3} \\ 4 & B_{2}+B_{4} \\ 5 & B_{2}+B_{5} \\ 6 & B_{2}+B_{6}\end{array}$

* referentiegroep

Het effect van de benodigde tijd op de medische consumptie voor de referentiegroep wordt tot uitdrukking gebracht door de coëfficiënt $B_{2}$, terwijl dit effect voor bijvoorbeeld tijdbestedingsgroep 1 gevonden wordt door $B_{2}$ en $B_{1}$ te sommeren, voor groep 3 door $B_{2}$ en $B_{3}$ te sommeren enz. Het al dan niet significant zijn van de coëfficiënten van de interactie-term geeft antwoord op de vraag of het effect van de benodigde tijd op medische consumptie voor de betreffende groep al dan niet significant verschilt van dat van de referentiegroep. Bij de verwachting dat de referentiegroep een relatief hoge tijdswaardering heeft worden voor de coëfficiënten van de interactie-variabelen positieve waarden verwacht. In tabel 2.4. wordt hiervan een overzicht gegeven.

Met de beschikbare gegevens is het niet mogelijk om a priori de totale effecten van tijd voor de verschillende tijdbestedingsgroepen op een ordinale schaal te rangschikken. Op grond van de hierboven besproken criteria wordt voor de referentiegroep een relatief sterker effect en voor de groep niet-actieven een relatief minder sterk effect verwacht in vergelijking met de overige groepen. 
Tabell 2.4. Verwachte effecten van tijd op medische consumptie

\begin{tabular}{|c|c|c|c|}
\hline Tijdbestedingsgroep & $\begin{array}{l}\text { Verwacht } \\
\text { teken } \mathbb{B}_{2}\end{array}$ & $\begin{array}{l}\text { Verwacht teken van } \\
\text { coeffficiënt van } \\
\text { interactie waria- } \\
\text { belle }\end{array}$ & $\begin{array}{l}\text { Verwactit } \\
\text { totalal } \\
\text { effect }\end{array}$ \\
\hline
\end{tabular}

1. Full-time loontrekkers

2. Full-time directeuren en Zelfstandigen ${ }^{1)}$

3. Huisvrouwen met kind

4. Scholieren en studenten

5. Niet-actieven

6. Restgroep

$\begin{array}{lll}- & + & - \\ - & & - \\ - & + & - \\ - & + & - \\ - & + & -\end{array}$

1) deze groep functioneert als referentiegroep

Naast de eigen tijdprijs van de te verklaren variabelen zullen eveneens, voor zover beschikbaar, relevant te achten kruistijdprijzen in de modellen worden meegenomen. Tevens zal, rekening houdend met de in het vorige hoofdstuk besproken kritiek van Coffey (1983), een benadering van de tijdprijzen van overige goederen in de modellen worden opgenomen. Dit laatste gebeurt door opname van het inkomen per tijdseenheid in de modellen. In het vervolg zal dit inkomen per tijdseenheid eenvoudigheidshalve, de loonvoet genoemd worden. Van de eigen tijdprijs wordt een negatief effect op het gebruik werwacht en afhankelijk van het feit of de voorziening als een substituut dan wel als een complement beschouwd kan worden, wordt een positieve respectievelijk negatief effect van de kruistijdprijs verwacht.

\section{De geldprijs}

De geldprijs wordt in deze studie benaderd door middel van een dummy-variabele die de waarde 1 heeft als men niet volledig verzekerd is. De interpretatie van een eventueel te vinden effect van deze variabele dient met enige voorzichtighteid te gebeuren. Immers deze dummy-variabele is bij benadering ook een indicatie voor het onderscheid ziekenfonds- of particulier verzekerd. Dit wordt weroorzaakt door het feit dat individuen die voor deze dummy-variabele een waarde 1 scoren in alle gevallen particulier verzekerd zijn en degene die hierop een 0-waarde scoren in $95 \%$ van de gevallen ziekenfondsverzekerd zijn. Immers de keuze om zich al of niet te verzekeren voor bepaalde voorzieningen is in het Nederlandse ziektekostenverzekeringsstelsel alleen voorbehouden aan particulier verzekerden. Hierbij dient opgemerkt te worden dat hier gemeentelijke en provinciale ambtenaren die onder de zogenaamde ambtenarenregeling (zie Van de Ven, 1981) vallen tot de particulier verzekerden gerekend worden. Voor deze groep vormen eigen bijdragen zonder enige keuze een onderdeel van het verzekeringspakket. Hierdoor kunnen de gevonden resultaten met name bij de modellen waarbij de kans op een consult niet op eigen initiatief verklaard wordt, vertekend worden door effecten die optreden als gevolg van verschillen in artsenhonorering (bij huisartsen) of afspraaksystemen (bij specialisten). Immers huisartsen ontvangen voor ziekenfondsverzekerden een vast bedrag per jaar onafhankelijk van het aantal contacten, 
terwill voor particulier verzekerden een honorering per contact plaats vindt (Hofland en Wilms, 1984). Hierdoor kan het verwachte negatieve effect van de aanwezigheid van een geldprijs wel eens gedempt worden door het effect van arts-geïnduceerde vraag bij particulier verzekerden.

Van de Ven (1983) komt op grond van een groot aantal empirische studies naar de effecten van eigen bijbetalingen tot de conclusie dat:

het effect van de geldprijs lager is naarmate het aandeel van de tijdprijs toeneemt;

het prijseffect toeneemt naarmate het inkomen lager is;

het prijseffect toeneemt naarmate de patiënt meer invloed heeft op de beslissing om al of niet gebruik te maken van voorzieningen;

het prijseffect toeneemt naarmate de urgentie voor medische zorg afneemt.

Tot slot zullen naast de eigen geldprijs ook eventuele kruisgeldprijzen in de modellen worden opgenomen. Evenals bij de tijdprijzen worden ook hier negatieve geldprijseffecten verwacht en afhankelijk van het gegeven of de betreffende voorziening functioneerd als een complement dan wel als een substituut, worden er van de kruisgeldprijzen positieve respectievelijk negatieve effecten verwacht.

\section{Inkomen}

Inkomenseffecten zullen, afgezien van een tijdprijseffect (als gevolg van substitutie), alleen dan optreden indien er sprake is van geldprijzen. Dit laatste doet zich echter alleen voor bij niet (geheel) verzekerde particulieren. Onder gelijkhouding van alle andere variabelen en onder de veronderstelling dat er sprake is van een normaal goed wordt werwacht dat inkomen een positief effect heeft op het gebruik van voorzieningen.

\section{Het aanbod}

Deze variabele wordt geacht, zoals reeds gesteld, in die vraagfuncties een rol te spelen, die betrekking hebben op medische consumptie waarbij de arts een initierende rol speelt. Operationalisatie vindt plaats door de opnamen van zgn. dichtheidsratio"s, bijvoorbeeld het aantal huisartsen per 1.000 inwoners. Hierbij wordt op grond van de eerder genoemde theoretische overwegingen een positief verband met gebruik verwacht. Pauly (1980) heeft bij het vaststellen van aanbodeffecten op grond van dergelijke samenhangen enige nuancerende opmerkingen gemaakt. Op de eerste plaats stelt hij dat het een uitdrukking is van een voorheen niet gerealiseerd vraagoverschot. Daarnaast kan een gevonden aanbodeffect ook een uitdruking zijn van een afname van de tijdprijs als gevolg van een reductie van de reis- en wachttijden. Ten derde stelt hij dat een hogere specialistendichtheid ook het gevolg kan zijn van een relatief hoge vraag in de betreffende regio. Tot slot oppert hij de mogelijkheid dat een gevonden samenhang inderdaad uitdrukking is van een "echt" aanbodeffect, in die zin dat artsen juist bij een hogere dichtheid de vraag zullen beinvloeden om een bepaald inkomen te realiseren. De zuiverheid van een eventueel vast te stellen aanbodeffect met deze dichtheidsvariabele wordt verhoogd door zo goed mogelijk te corrigeren voor de vraag beïnvloedende variabelen als gezondheidstoestand, tijdprijs etc. 
De huisartsendichtheild werd verkregen op basis van gegevens van het Nederlands Huisartsen Instituat en de gemeentelijke bevolkingsstatistiek van het CBS. De specialisten- en beddendichtheid werd berekend op basis wan "toewijzing" van specialisten en bedden aan gemeenten op basis van de $\mathrm{zgn}$. patiëntenherkomstgegevens van de Geneeskundige Hoofdinspectie. Van Vliet en Van Doorslaer (1987) verwijzen in hun studie over aggregatie en aanbodeffecten naar een kritiek van Vos en Bikker die stellen dat op deze wijze geconstrueerde aanbodgegevens uiteraard sterke samenhang zullen vertonen met het gebruik van voorzieningen, omdat het aanbod over regio's verdeeld wordt op basis van hetzelfde gebruik. Deze kritiek is met name relevant indien het gebruik ook op datzelfde regional niveau verklaard wordt. $\mathrm{Bij}$ de verklaring van gebruik op individueel niveau, zoals in deze studie het geval is, en waarbij tevens individuele variabelen worden meegenomen, lijkt het gevaar van een "geconstrueerde" samenhang met cen dergelijke omgevingsvariabele niet aan de orde.

\section{Consumentenwoorkeur}

In de modellen ter verklaring van medische consumptie zullen variabelen met betrekking tot de gezondheidstoestand en het opleidingsniveau beschouwd worden als factoren die de voorkeur wan de consument beinvloeden onafhankelijk van de prijs- en inkomensvariabelen. Er worden een vijftal gezondheidsindicatoren in de vraagmodellen opgenomen.

De eerste is de zgn. perceptie van de eigen gezondheidstoestand. Hierbij beoordeelt de respondent zijn of haar eigen gezondheidstoestand met de kwalificaties slecht, wisselvallig, gaat wel en goed. In de schattingsmodellen is deze variabele meegenomen als een dummy variabele met de waarde 1 in geval van de eerste 3 kwalificaties en 0 indien de respondent zijn gezondheidstoestand met de kwalificatie "goed" beoordeelt. De tweede variabele is een meer objectieve indicatie van de structurele gezondheidstoestand, nl. het aantal langdurige aandoeningen dat men heeft.

Vervolgens is leeftijd als een derde indicator meegenomen. Met de toename van leeftijd zal de incidentie van ziekte toenemen en treden er verschuivingen op in het morbiditeitspatroon. Als vierde indicator is er een dummy variabele opgenomen die de waarde 1 heeft indien de respondent een vrouw is in de leeftijd van 18 tot en met 45 jaar. Verondersteld wordt dat deze groep extra medische consumptie heeft in verband met vruch tbaarheid en zwangerschap.

Een laatste variabele, die meer cen indicatie is van de actuele gezondheidstoestand, heeft betrekking op het aantal dagen dat men het de afgelopen dagen rustig aan heeft gedaan.

Ten aanzien van al deze variabelen wordt een positief verband met medische consumptie verwacht.

Opleiding wordt in de te schatten vraagmodellen opgenomen als een variabele die zowel een indicatie voor de gezondheidstoestand van een individu alswel een indicatie voor een betere geïnformeerdheid is. In de recente studie van Van Doorslaer (1987) wordt de positieve samenhang tussen gezondheidstoestand en opleiding op basis van Nederlandse gegevens nog eens bevestigd. De veronderstelde betere geïnformeerdheid van hoger opgeleiden kan om verschillende redenen met de vraag naar zorg. samenhangen. Betere geinformeerdheid kan ertoe leiden dat iemand in een vroeger stadium symptomen onderkent en professionele hulp zoekt. In de hierboven aangehaalde studie van Van Doorslaer wordt op basis van Belgische gegevens gevonden dat bij betere geïnformeerdheid de kans op een door de patiënt geïnitieerd 
huisarstencontact toeneemt, terwijl de kans op een door de arts geinitieend contact afneemt. De tweede weg waarlangs geïnformeerdheid medische consumptie beînvloed is het door Grossman (zie par. 1.4) veronderstellde efficientie-effect. Daarnaast veronderstelt Muurinen (1982) dat betere geïnformeerdheid een remmende werking op de depreciatievoet van gezondheid heef. Op grond van het bovenstaande wordt van een variabele opleiding een negatief effect op medische consumptie verwacht.

\subsection{DE GEBRUIKTE ANALYSE TECHNIEK}

In deze studie wordt gebruik gemaakt van multiple regressie-analyse (Wonnacott en Wonnacott, 1981; Amemiya, 1985). Met behulp van deze techniek is het mogelijk partiële correlatie coëfficiènten te schatten. Deze partiële correlatie coëfficiënten geven de samenhang weer tussen een bepaalde onafhankelijke en de afhankelijke variabele, waarbij de overige onafhankelijke variabelen constant worden gehouden. Op deze wijze kan de samenhang van bijvoorbeeld tijdprijzen op medische consumptie geschat worden, waarbij voor de overige relevant geachte variabelen gecorrigeerd wordt. De in deze studie te verklaren variabelen zijn in diverse modellen dichotoom. Dat wil zeggen dat deze de waarde 0 hebben als er geen sprake is van medische consumptie (de gebeurtenis doet zich niet voor) en waarde 1 indien hier wel sprake van is (de gebeurtenis treedt wel op). Een dergelijke variabele heeft een verdelingskarakteristiek die niet aan de eis van normaliteit voldoet. Tevens voldoet de te schatten functie niet aan de eis van lineariteit in de parameters. Deze heeft eerder het verloop van een S-curve. Met andere woorden er is niet voldaan aan de veronderstellingen die ten grondslag liggen aan het gebruik van de gewone kleinste-kwadratenmethode (Cleary and Angel, 1984). Toepassing van deze methode leidt in dat geval tot inefficiënte schatters van de regressiecoëfficiënten. Daarnaast garandeert een lineaire specificatie niet dat de geschatte waarden van de te verklaren variabele tussen de 0 en de 1 liggen (zie ook Amemiya (1981) voor een overzicht van multivariate dichotome modellen).

Door de logistische transformatie van de afhankelijke variabele wordt het verloop van haar verdeling volgens een S-curve benaderd. Hierbij verloopt een dergelijke verdelingsfunctie asymptiotisch naar 0 en 1 , waardoor de geschatte waarden tussen 0 en 1 komen te liggen. De afhankelijke variabele is hier de kans op medische consumptie (p) of anders gezegd de proportie van de schattingspopulatic met de gegeven waarden $X_{1}, \ldots, X_{k}$ van de verklarende variabelen waarvoor $Y=1$. Dus:

$E(Y \| X)=\frac{1}{1+e^{-(\alpha+B X)}}$

De relatie

$P=\frac{1}{1+e^{-(\alpha+\beta X)}}$ 
kan worden geschreven als

$\operatorname{Ln} \frac{p}{1-p}=\alpha+B X$

waarbij:

$p \quad=$ kans op medische consumptie

$\mathrm{X}=$ vector van alle verklarende variabelen

B = vector van de te schatten coëfficiënten

$a=$ constante

De term "In $\frac{\mathrm{p}}{1-\mathrm{p}}$ " wordt log odds of ook wel logit (p) genoemd. Voor het schatten van logistische functies kan er niet zonder meer gebruik worden gemaakt van de gewone kleinste-kwadratenmethode omdat in het geval $p=0$ of $p=1$ de log wordt opgeblazen. Eveneens is de variantie in de storingsterm niet constant (Peck en Montgomery, 1982). Schatting van deze modellen zal derhalve plaatsvinden met behulp van de maximum likelihood methode. Bij deze schattingstechniek wordt er naar die set van coëfficiënten gezocht, waarbij het model met de grootste waarschijnlijkheid de schattingspopulatie weerspiegelt. Dit gebeurt niet met behulp van expliciete formules zoals bij de gewone kleinste-kwadratenmethode, maar door een zoekprocedure (Wonnacott en Wonnacot, 1981). Hierbij wordt de waarschijnlijkheidsfunctie $L(\alpha, B)^{\mathbb{1})}$ gemaximeerd. Ten behoeve van deze studie werd gebruik gemaakt van BMDP-progammatuur (Zie voor een beschrijving Dixon (1985)).

Noten

1) De waarschijnlijkheidsfunctie $L(\alpha, B)$ is, gegeven individuen $i=1$...N, een vektor van verklarende variablen $X_{i}$ en te verklaren variabele $Y_{i}=[i$, , de volgende functie:

$L(\alpha, B)=\prod_{i=1}^{n} p\left(\alpha, B ; X_{i}\right)^{Y_{i}}\left(1-p\left(\alpha, B ; X_{i}\right)\right)^{1-Y_{i}}$

De maximum likelihood schatter is gedefinieerd als die waarden van $B$ die de waarde van deze functie maximeert. Zie voor een beschrijving van de gehanteerde zoekprocedure voor het vinden van het maximum (Dixon, 1985). 
"Wanneer zullen we het doen?" Dit is de oorspronkelijke vraag die mensen ertoe heeft gebracht zich op de avontuurlijke weg van het tijdbepalen te begeven." (Elias, 1985)

\subsection{INLEIDING}

Zoals uit het in paragraaf 2.3. gepresenteerde schema van de Nederlandse gezondheidszorg blijkt, komt de gebruiker van voorzieningen over het algemeen via de huisarts het voorzieningensysteem binnen. Met name bij het gebruik van de huisarts is het onderscheid tussen "eigen initiatief" en "niet eigen initiatief" relevant. Verondersteld wordt dat bij contacten op eigen initiatief de tijdprijs van de gebruiker een groter effect zal hebben dan wanneer dit contact niet op eigen initiatief plaats vindt. In paragraaf 3.2. wordt ingegaan op de specificatie van het schattingsmodel voor huisartsgebruik, waarbij de aandacht geconcentreerd is op de economische variabelen. In dit hoofdstuk zullen afhankelijk van de wijze waarop het tijdprijsconcept geoperationaliseerd wordt voor twee onderzoekspopulaties modellen geschat worden. Alvorens in paragraaf 3.3. de schattingsresultaten te presenteren zullen in diezelfde paragraaf de deelpopulaties op een aantal kenmerken met elkaar vergeleken worden. Paragraaf 3.4. bevat een samenvatting en conclusies. 


\subsection{SPECIFICATUE VAN DE SCHATTINGSMODELLEN}

De eventuele aarwezigheid van tijdprijseffecten zal in dit hoofdstuk met behulp van een tweetal modellen getoetst worden. In model I is het effect van de tijdprijs op de kans op een contact met de huisarts over een periode van 3 maanden geschat. Dit contact wond in alle gevallen plaats op initiatief van de patiënt. In model II wordt het effect van de tijdprijs geschat op de kans op contacten niet op eigen initiatief. Bij deze laatst genoemde vorm van consumptie is sprake van een herhalingscontact bij dezelfde huisarts of is de betrokken persoon doorverwezen door een andere arts, specialist of hulpverlener.

De hier gerapporteerde contacten vinden plaats in de praktijk van de huisarts. We spreken in dit geval verder van consulten. Dit betekent dat visites van de arts bij de patiënt thuis en telefonische contacten niet worden meegenomen. Van de in totaal 6341 wargenomen contacten in de Gezondheidsenquête vindt $81 \%$ in de praktijk van de huisarts plaats, in circa $13 \%$ van de gevallen bezoekt de arts de patiënt thuis en in circa $5 \%$ van de gevallen vindt het contact telefonüsch plaats. De in de enquête gerapporteerde tijd heeft betrekking op een bezoek aan de huisarts. Vandaar de hierboven gemaakte keuze om de visites en telefonische contacten verder buiten beschouwing te laten.

Voor de beide genoemde basismodellen worden een drietal varianten geschat. Deze varianten onderscheiden zich door de wijze waarop de tijdprijs geoperationaliseerd wordt. In de eerste twee varianten wordt de benodigde tijd voor een huisartsbezoek als benadering voor de tijdprijs in het model opgenomen. Hierbij wordt met behulp van een aantal interactieve dummy-variabelen nagegaan of en in hoeverre de zogenaamde hoofdbezigheden van individuen een eventueel effect van de benodigde tijd beïnvloeden. Middels deze dummies worden er een zestal groepen onderscheiden die verondersteld worden een specifieke tijdswaardering te hebben (zie paragraaf 2.4.). Met behulp van deze interactieve dummy-variabelen wordt de benodigde tijd gemerkt voor de "normale" tijdbesteding van een individu. Dit gebeurt door voor alle groepen behalve de referentiegroep een interactieve dummy-variabele voor de benodigde tijd op te nemen in het schattingsmodel (model I A). In model I B wordt voor elke afzonderlijke groep getoetst of de benodigde tijd een significant effect heeft op de kans op een consult. Dit gebeurt door de variabele "benodigde tijd" niet zoals in model I A afzonderlijk op te nemen, maar deze voor elke tijdbestedingsgroep interactief op te nemen. Aannemende dat voor al deze groepen tijd een positieve waarde heeft wordt voor elke groep een negatief tijdprijseffect verwacht.

In de derde variant (I $C$ ) wordt de tijdprijs voor een huisartsenbezoek op de wijze zoals beschreven in paragraaf 2.3. met behulp van de alternatieve kosten berekend. Deze operationalisatie van de tijdprijs heeft als gevolg dat de onderzoekspopulatie aanmerkelijk gereduceerd wordt. Immers er vindt hierbij selectie plaats op die respondenten die opgeven een inkomen uit arbeid te hebben en waarvan dit inkomen bekend is. De verwachting is dat de coefficiënt van de tijdprijsvariabele een negatieve waarde zal hebben. In het laatste model wordt in navolging van Coffey (1983) een variabele in het model opgenomen die een benadering is voor de tijdprijzen van de overige goederen. Dit gebeurt middels de opname van de loonvoet als een benadering voor de alternatieve kosten van een tijdseenheid in het model. 
De modellen II A, II B en II C corresponderen wat de onderzoekspopulaties betreft met de hierboven beschreven modellen I A, I B en I C. Deze hebben echter zoals hiervoor gesteld betrekking op de verklaring van de kans op een consult niet op eigen initiatief. Hierbij worden minder sterke samenhangen verwacht van de tijdprijswariabelen dan in de type I modellen die betrekking hebben op consulten op initiatief van de patiënt. In tabel 3.1. wordt een overzicht gegeven van de verschillen tussen de modellen waarvan in dit hoofdstuk de schattingsresultaten worden gepresenteerd.

\section{Tabel 3.1. Overzicht van verschillen tussen de schattingsmodiellen}

\begin{tabular}{|c|c|c|c|c|c|c|}
\hline Model aanduiding: & II A & I B & I C & II A & $11 \mathrm{~B}$ & II $\mathrm{C}$ \\
\hline $\begin{array}{l}\text { Te verklaren varlabelen: } \\
\text { Kans op minstens één consult op } \\
\text { eigen initiatief bij de huisarts }\end{array}$ & $x$ & $x$ & $x$ & & & \\
\hline $\begin{array}{l}\text { Kans op minstens één consult } \\
\text { niet op eigen initiatief bij de } \\
\text { huisarts }\end{array}$ & & & & $x$ & $x$ & $x$ \\
\hline $\begin{array}{l}\text { Verklarende variabelen: } \\
\text { Benodigde tijd }\end{array}$ & * & & & $x$ & & \\
\hline $\begin{array}{l}\text { Benodigde tijd } x \text { interactie-term } \\
\text { voor } 5 \text { tijdbes tedingsgroepen }\end{array}$ & $x$ & & & $x$ & & \\
\hline $\begin{array}{l}\text { Benodigde tijd } x \text { interactie-term } \\
\text { voor alle } 6 \text { tijdbestedingsgroepen }\end{array}$ & & $x$ & & & $x$ & \\
\hline Benodigde tijd $\times$ loonwoet & & & $x$ & & & $x$ \\
\hline Loonvoet & & & $x$ & & & $x$ \\
\hline Huisartsendichtheid & & & & $x$ & $x$ & $x$ \\
\hline $\begin{array}{l}\text { Omvang onderzoekspopulatles: } \\
\text { Alle personen van } 16 \mathrm{t} / \mathrm{m} 64 \mathrm{Jr} \text {. }\end{array}$ & ж & $x$ & & $x$ & $x$ & \\
\hline $\begin{array}{l}\text { Personen }(16 \mathrm{t} / \mathrm{m} 64 \mathrm{jr} .) \text { met een } \\
\text { inkomen uit arbeid }\end{array}$ & & & $x$ & & & $x$ \\
\hline
\end{tabular}

Een overzicht van de gemiddelde waarden en de standaardfouten van de gemiddelden is in tabel 3.2. opgenomen. Hierbij zijn apart vermeld, de gegevens die betrekking hebben op de onderzoekspopulatie van de modellen $A$ en $B$ respectievelijk $C$, en de onderscheiden tijdbestedingsgroepen in de modellen A en B. Uit dit overzicht blijkt dat van de tijdbestedingsgroepen 3 en 6 een enigszins groter deel dan van de totale onderzoekspopulatie van de modellen I A/B kans maakt op minstens én consult op eigen initiatief. De respectievelijke waarden bedragen 0,34 en 0,35 , terwijl dit voor de gehele populatie op 0,31 ligt. Voor de tijdbestedingsgroepen 2, 4 en 5 zijn deze proporties aanmerkelijk kleiner, nl respectievelijk 0,20 en 0,21 en 0,26 . De kans op een consult niet op eigen initiatief ligt voor de tijdbestedingsgroepen 3 en 5 hoger $(0,14$ respectievelijk 0,16 ) dan voor de gehele onderzoekspopulatie van de modellen $\mathrm{A}$ en B $(0,10)$. Voor de tijdbestedingsgroepen 2 en 4 liggen deze kansen relatief lager $(0,07$ 
Tabal 3 a

Cemiddelden van de athankallike on onathankelfke varkabelen par onderzoekepopulatle (Modilal I en II)

(de standaardfout wan het geniddelde is tussen haakjes opgenomen.

\begin{tabular}{|c|c|c|c|c|c|c|c|c|}
\hline \multirow[t]{3}{*}{ Onderzoekspopulatie: } & \multicolumn{5}{|c|}{ model $A$ en $B$} & & & \multirow[t]{2}{*}{ Model C } \\
\hline & \multicolumn{7}{|c|}{ Ti jubes tedingsgroep: } & \\
\hline & Totaal & $\pi$ & 2 & 3 & 4 & 5 & 6 & \\
\hline Kans op consult elg. inft. (a) & $\begin{array}{c}0.31 \\
{[0.01]}\end{array}$ & $\begin{array}{c}0.31 \\
{[0.01]}\end{array}$ & $\begin{array}{c}0.20 \\
{[0.02]}\end{array}$ & $\begin{array}{c}0.34 \\
{[0.01]}\end{array}$ & $\begin{array}{c}0.21 \\
{[0.02]}\end{array}$ & $\begin{array}{c}0.26 \\
{[0.02]}\end{array}$ & $\begin{array}{c}0.35 \\
{[0.01]}\end{array}$ & $\begin{array}{c}0.33 \\
{[0.01]}\end{array}$ \\
\hline Kans op consulte & & & & & & & & \\
\hline niet elg. fnit. (a) & $\begin{array}{c}0.10 \\
{[0.00]}\end{array}$ & $\begin{array}{c}0.09 \\
{[0.01]}\end{array}$ & $\begin{array}{c}0.07 \\
{[0.01]}\end{array}$ & $\begin{array}{c}0.14 \\
{[0.01]}\end{array}$ & $\begin{array}{c}0.04 \\
{[0.01]}\end{array}$ & $\begin{array}{c}0.16 \\
{[0.02]}\end{array}$ & $\begin{array}{c}0.11 \\
{[0.01]}\end{array}$ & $\begin{array}{c}0.10 \\
{[0.01]}\end{array}$ \\
\hline Benodigde tijd (b) & $\begin{array}{l}42 . \pi 7 \\
{[0.34]}\end{array}$ & $\begin{array}{l}42.23 \\
{[0.56]}\end{array}$ & $\begin{array}{l}38.84 \\
{[1.18]}\end{array}$ & $\begin{array}{l}42.53 \\
{[0.77]}\end{array}$ & $\begin{array}{r}42.28 \\
{[1.11]}\end{array}$ & $\begin{array}{l}47.46 \\
{[1.36]}\end{array}$ & $\begin{array}{l}43.65 \\
{[0.71]}\end{array}$ & $\begin{array}{l}43.09 \\
{[0.59]}\end{array}$ \\
\hline Tijdprijs (b) & & & & & & & & $\begin{array}{l}12.41 \\
{[0.01]}\end{array}$ \\
\hline Whet geh. verz. huisarts (a) & $\begin{array}{c}0.26 \\
{[0.01]}\end{array}$ & $\begin{array}{c}0.21 \\
{[0.01]}\end{array}$ & $\begin{array}{c}0.50 \\
{[0.03]}\end{array}$ & $\begin{array}{c}0.30 \\
{[0.01]}\end{array}$ & $\begin{array}{r}0.40 \\
{[0.02]}\end{array}$ & $\begin{array}{c}0.08 \\
{[0.01]}\end{array}$ & $\begin{array}{c}0.26 \\
{[0.01]}\end{array}$ & $\begin{array}{c}0.24 \\
{[0.01]}\end{array}$ \\
\hline Afstand ziekenhuis (b) & $\begin{array}{c}6.06 \\
{[0.06]}\end{array}$ & $\begin{array}{c}5.94 \\
{[0,10]}\end{array}$ & $\begin{array}{c}7.21 \\
{[0.28]}\end{array}$ & $\begin{array}{c}6.59 \\
{[0.14]}\end{array}$ & $\begin{array}{r}5.51 \\
{[0.19]}\end{array}$ & $\begin{array}{c}5.93 \\
{[0.25]}\end{array}$ & $\begin{array}{c}5.74 \\
{[0.12]}\end{array}$ & $\begin{array}{c}5.81 \\
{[0.10]}\end{array}$ \\
\hline Inkomen & & & & & & & & $\begin{array}{l}31.500 \\
{[0.06]}\end{array}$ \\
\hline Loonvoet & & & & & & & & $\begin{array}{c}0.30 \\
{[0.00]}\end{array}$ \\
\hline Hulsartsen dichtheid & $\begin{array}{c}0.37 \\
{[0.00]}\end{array}$ & $\begin{array}{c}0.37 \\
{[0.00]}\end{array}$ & $\begin{array}{c}0.38 \\
{[0.00]}\end{array}$ & $\begin{array}{l}0.36 \\
{[0.00]}\end{array}$ & $\begin{array}{c}0.36 \\
{[0.00]}\end{array}$ & $\begin{array}{c}0.38 \\
{[0.00]}\end{array}$ & $\begin{array}{c}0.37 \\
{[0.00]}\end{array}$ & $\begin{array}{c}0.37 \\
{[0.00]}\end{array}$ \\
\hline Leeftyjd & $\begin{array}{l}37.20 \\
{[0.18]}\end{array}$ & $\begin{array}{l}34.88 \\
{[0.25]}\end{array}$ & $\begin{array}{l}41.97 \\
{[0.60]}\end{array}$ & $\begin{array}{l}39.77 \\
{[0.32]}\end{array}$ & $\begin{array}{r}18.40 \\
{[0.13]}\end{array}$ & $\begin{array}{l}45.06 \\
{[0.78]}\end{array}$ & $\begin{array}{l}42.20 \\
{[0.39]}\end{array}$ & $\begin{array}{l}35.41 \\
{[0.26]}\end{array}$ \\
\hline Gezondhe ids toes tand la) & $\begin{array}{c}0.20 \\
{[0.01]}\end{array}$ & $\begin{array}{c}0.15 \\
{[0.01]}\end{array}$ & $\begin{array}{c}0.14 \\
{[0.02]}\end{array}$ & $\begin{array}{c}0.21 \\
{[0.01]}\end{array}$ & $\begin{array}{c}0.06 \\
{[0.01]}\end{array}$ & $\begin{array}{c}0.51 \\
{[0.02]}\end{array}$ & $\begin{array}{c}0.23 \\
{[0.01]}\end{array}$ & $\begin{array}{c}0.15 \\
{[0.01]}\end{array}$ \\
\hline Langdurige aandoeningen (b) & $\begin{array}{c}0.33 \\
{[0.011]}\end{array}$ & $\begin{array}{c}0.27 \\
{[0.01]}\end{array}$ & $\begin{array}{c}0.22 \\
{[0.03]}\end{array}$ & $\begin{array}{c}0.31 \\
{[0.02]}\end{array}$ & $\begin{array}{c}0.14 \\
{[0.02]}\end{array}$ & $\begin{array}{c}0.81 \\
{[0.05]}\end{array}$ & $\begin{array}{c}0.14 \\
{[0.02]}\end{array}$ & $\begin{array}{c}0.18 \\
{[0.01]}\end{array}$ \\
\hline Wroulwen $18-45 \mathrm{jr} .(\mathrm{a})$ & $\begin{array}{c}0.32 \\
{[0.01]}\end{array}$ & $\begin{array}{c}0.17 \\
{[0.01]}\end{array}$ & $\begin{array}{c}0.10 \\
{[0.02]}\end{array}$ & $\begin{array}{c}0.69 \\
{[0.01]}\end{array}$ & $\begin{array}{c}0.19 \\
{[0.02]}\end{array}$ & $\begin{array}{c}0.09 \\
{[0.01]}\end{array}$ & $\begin{array}{c}0.42 \\
{[0.01]}\end{array}$ & $\begin{array}{c}0.26 \\
{[0.01]}\end{array}$ \\
\hline Dagen belen. aktiviteiten (a) & $\begin{array}{c}0.10 \\
{[0.00]}\end{array}$ & $\begin{array}{c}0.11 \\
{[0.01]}\end{array}$ & $\begin{array}{c}0.05 \\
{[0.01]}\end{array}$ & $\begin{array}{c}0.09 \\
{[0.01]}\end{array}$ & $\begin{array}{c}0.03 \\
{[0.01]}\end{array}$ & $\begin{array}{c}0.15 \\
{[0.02]}\end{array}$ & $\begin{array}{c}0.13 \\
{[0.01]}\end{array}$ & $\begin{array}{c}0.11 \\
{[0.01]}\end{array}$ \\
\hline opleiding & $\begin{array}{c}2.49 \\
{[0.01]}\end{array}$ & $\begin{array}{c}2.63 \\
{[0.02]}\end{array}$ & $\begin{array}{c}2.57 \\
{[0.04]}\end{array}$ & $\begin{array}{c}2.19 \\
{[0.02]}\end{array}$ & $\begin{array}{c}2.97 \\
{[0.03]}\end{array}$ & $\begin{array}{c}2.12 \\
{[0.04]}\end{array}$ & $\begin{array}{c}2.44 \\
{[0.02]}\end{array}$ & $\begin{array}{c}2.68 \\
{[0.02]}\end{array}$ \\
\hline Kontakt telefoon/vistite (a) & $\begin{array}{c}0.03 \\
{[0.00]}\end{array}$ & $\begin{array}{c}0.02 \\
{[0.00]}\end{array}$ & $\begin{array}{c}0.03 \\
{[0.01]}\end{array}$ & $\begin{array}{c}0.03 \\
{[0.01]}\end{array}$ & $\begin{array}{c}0.01 \\
{[0.00]}\end{array}$ & $\begin{array}{c}0.04 \\
{[0.01]}\end{array}$ & $\begin{array}{c}0.03 \\
{[0.00]}\end{array}$ & $\begin{array}{c}0.02 \\
{[0.00]}\end{array}$ \\
\hline M & 6008 & 2201 & 364 & 143 & 514 & 417 & 1369 & 2082 \\
\hline
\end{tabular}

(a): De betreffende varlabele is een dumm-variabele.

(b): Waarden vór logari tmische transformatie. 
respectievelijk 0,04). De onderzoekspopulatie waarop de modellen $A$ en $B$ respectievelijk $C$ gebaseerd zijn verschillen statistisch niet wat betreft de kans op een consult op eigen initiatief noch wat betreft de kans op een consult niet op eigen initiatief.

De gemiddelde waarden van de variabele "benodigde tijd" van de diverse tijdbestedingsgroepen verschillen nauwelijks van het gemiddelde voor de totale populatie, dat ruim 42 minuten bedraagt. Uitzondering hierop vormt tijdbestedingsgroep 2, die gemiddeld kortere tijd nodig heeft en tijdbestedingsgroep 5 die gemiddeld een enigszins langere tijd nodig heeft. In de modellen I $\mathrm{C}$ en II $\mathrm{C}$, waarin de benodigde tijd gewaardeerd wordt met behulp van de loonvoet bedraagt het gemiddelde van de tijdprijs voor de relevante onderzoekspopulatie $f 12,41$. Als benadering voor de aanwezigheid van een geldprijs is er in de modellen een dummy-variabele opgenomen die de waarde 1 aanneemt indien er sprake is van een niet volledige verzekeringsdekking voor de huisarts. De gemiddelde waarde van deze variabele bedraagt voor de gehele onderzoekspopulatie van de modellen I A/B 0,26. Binnen tijdbestedingsgroep 2 bevinden zich relatief de meeste personen die niet (geheel) verzekerd zijn voor de huisarts (50\%), terwijl dit percentage eveneens hoger dan gemiddeld ligt voor tijdbestedingsgroep $3(30 \%)$ en voor groep $4(40 \%)$. Binnen tijdbestedingsgroep 5 bevinden zich relatief de minste personen die niet (geheel) verzekerd zijn voor de huisarts $(8 \%)$, terwijl dit percentage voor tijdbestedingsgroep 1 eveneens lager dan gemiddeld ligt.

De afstand tot het ziekenhuis is in het model opgenomen als een benadering woor cen mogelijk optredend kruisprijseffect dat uitgaat van poliklinische hulp. Of een dergelijk kruisprijseffect in negatieve of positieve richting werkt is afhankelijk van het gegeven of beide voorzieningen te beschouwen zijn als complementen of substituten. Gaat men naar de huisarts met het oog op een verwijskaart voor de specialist dan is er sprake van een complementair karakter en mag men een negatief kruisprijseffect verwachten. Functioneert een contact met de huisarts echter als een substituut voor een specialistencontact mag men een positief kruisprijseffect verwachten. Intuitief lijkt het redelijk te veronderstellen dat bij het eerste contact op eigen initiatief het complementair karakter een relatief sterkere rol speelt en het voorwaardelijk aantal contacten niet op eigen initiatief meer als substituten te beschouwen zijn. In het laatste geval kan het contact immers geïnitieerd zijn door de specialisı die de controles van behandeling overdraagt aan de huisarts. Deze veronderstelling wordt bevestigd door de bevindingen van Van der Zee (1982). De gemiddelde afstand tot het dichtsbijzijnde ziekenhuis bedraagt voor de gehelle onderzoekspopulatie van de modellen A en B ruim 6 kilometer. Groepen 4 en 6 blijken met een gemiddelde van $5,5 \mathrm{~km}$ respectievelijk 5,7 $\mathrm{km}$ relatief dichter bij een ziekenhuis te wonen en groep 2 en 3 met respectievelijk 7,2 en $6,6 \mathrm{~km}$ relatief verder verwijderd van een ziekenhuis te wonen. De onderzoekspopulatie van de C-modellen woont gemiddeld $(5,8 \mathrm{~km})$ iets dichter bij een ziekenhuis dan de onderzoekspopulatie van de modellen $A$ en $B(6,1 \mathrm{~km})$.

Naast de hierboven genoemde (tijd)-prijsvariabelen is het netto huishoudinkomen in de modellen I $\mathrm{C}$ en II $\mathrm{C}$ opgenomen om te toetsen of er sprake is van een inkomenseffect. Bij de bespreking van het onderliggende theoretische model van Acton (zie par. 1.3.) is reeds gesteld dat bij afwezigheid van geldprijzen een toename van het inkomen negatieve tijdprijseffecten zal genereren en er geen positief inkomenseffect verwacht wordt. Het voorgaande betekent dat er alleen bij de groep, die niet geheel verzekerd 
is voor deze consumptie-categorie er sprake zou kunnen zijn van een positief inkomenseffect. De gemiddelde waarde van het netto huishoudinkomen van de onderzoekspopulatie van de modellen I $\mathrm{C}$ en II $\mathrm{C}$ bedraagt $f 31.000,-$

Vervolgens is in de modellen voor de kans op een consult niet op eigen initiatief de huisartsendichtheid als onafhankelijke variabele opgenomen. Dit om een eventueel positief aanbodeffect waar te nemen. In verband met de specifieke kenmerken van het vergoedingssysteem voor huisartsen wordt de relatie tussen aanbod en wraag bij huisartsenhulp gekenmerkt door een zekere dualiteit. Voor wat betreft de hulp aan ziekenfondsverzekerden is er vanwege de honorering op basis van een vast bedrag per jaar (het zogenaamde abonnement) geen direkte relatie met het inkomen van de arts. Deze kan zijn inkomen verhogen door het aantal bij hem ingeschreven ziekenfondsverzekerden te vergroten, het verlenen wan zorg aan particuliere patięnten, die immers wel per consult betalen, en het verrichten van newenwerkzaamheden. Dit houdt in dat er voor de huisarts economische prikkels aanwezig zijn om herhalingscontacten bij ziekenfondsverzekerden te beperken onder andere door deze eerder door te verwijzen (Van der Zee, 1982, p. 107). Gezien het feit dat ziekenfondsverzekerden gemiddeld circa $70 \%$ van het patièntenbestand van een huisarts uitmaken verwachten we een dominantie van de negatieve relatie die hierboven geschetst is tussen inkomen en herhalingscontacten van ziekenfondsverzekerden. Derhalve wordt er een negatief verband verwacht tussen de huisartsendichtheid en consulten niet op eigen initiatief. Zoals uit tabel 3.2. blijkt verschillen de gemildelde waarden van de huisartsendichtheid rekening houdend met afrondingsmarges nauwelijks voor de verschillende onderzoekspopulaties noch voor de diverse tijdbestedingsgroepen.

Vervolgens is de in paragraaf 2.3. beschreven set van gezondheidsvariabelen, te bechouwen als voorkeurvariabelen, in de modellen opgenomen. Uit de vergelijking van de gemiddelde leeftijd van de deelpopulaties met die van de totale onderzoeksgroep ( 38 jr.) van de modellen $A$ en $B$ blijkt dat de tijdbestedingsgroepen 1 en 4 relatief jong zijn met een gemiddelde van $35 \mathrm{jr}$ respectievelijk $18 \mathrm{jr}$ en de tijdbestedingsgroepen 2,5 en 6 relatief oud zijn, de eerste twee met een gemiddelde van 42 jr en de laatste met een gemiddelde van $45 \mathrm{jr}$. De waarden van de variabele met betrekking tot de eigen perceptie van de gezondheidstoestand geeft de fractie van de populatie aan die zijn gezondheidstoestand waardeert als "gaat wel", "wisselend" of "slecht". Uit de gemiddelde waarden die deze variabele aanneemt blijkt dat de groepen 2,3 en 4 een enigszins betere gezondheid dan gemiddeld rapporteren en dat een aammerkelijk grotere fractie dan gemiddeld van groep 5 een als hierboven aangeduide waardering geeft. Dit beeld geldt tevens voor de rapportage van langdurige aandoeningen. De waarde van de dummy-variabele voor vrouwen in de leeftijd van 18 tot 45 jaar geeft het aandeel van deze groep in de verschillende deelpopulaties weer. In de tijdbestedingsgroepen 3 en 6 . ligt hun aandeel met $69 \%$ en $42 \%$ aanmerkelijk hoger dan in de totale onderzoekspopulatie van de A/B modellen (32\%). In de tijdbestedingsgroepen 1, 2, 4 en 5 ligt dit aandeel significant lager met respectievelijk $17 \%, 10 \%, 19 \%$ en $9 \%$. Ook binnen de onderzoekspopulatie van model $\mathrm{C}$ ligt het aandeel van vrouwen in de leeftijd van 18-45 jaar met $26 \%$ enigszins lager dan binnen de onderzoekspopulatie van de $\mathrm{A} / \mathrm{B}$ modellen. Bij de rapportage van de dummy-variabele "dagen met belemmerde activiteiten" onderscheiden zich met name de tijdbestedingsgroepen 2 en 4 met een gemiddelde waarde die de helft of minder bedraagt van die van de totale populatie. Van tijdbestedingsgroep 5, de niet-actieven, ligt deze fractie significant hoger dan van 
de totale onderzoekspopulatie. Van al deze gezondheidsvariabelen wordt verwacht dat zij positief samenhangen met medische consumptie.

Als laatste voorkeurvariabele is de opleiding van de respondenten in de vraagfuncties opgenomen. Uit tabel 3.2. blijkt dat binnen de onderzoekspopulatie van de modellen $A$ en $B$ de tijdbestedingsgroepen 1, 2 en 4 een hoger dan gemiddelde opleiding hebben en de groepen 3, 5 en 6 een lager dan gemiddeld. De onderzoekspopulatie van model $C$ heeft gemiddeld een hoger opleidingsniveau dan die van de modellen A en B. Op basis van de in paragraaf 2.3. genoemde redenen wordt er een negatief effect van opleidingsniveau verwacht.

Tot slot is een dummy-variabele opgenomen met de waarde 1 voor diegenen die in de beschouwde periode telefonisch contact hadden met de arts of waarbij de arts de patiënt thuis opzocht. Verondersteld wordt dat deze personen minder kans op consult in de praktijk van de arts zullen hebben. In een studie van Van Sonsbeek (1984) naar de effecten van reistijd op huisartscontacten lijkt deze veronderstelling bevestigd te worden. Normaliter worden van mogelijke substituten de prijzen in een vraagfunctie opgenomen. Hierbij wordt echter aangenomen dat de arts in laatste instantie beslist of hij de patiênt thuis zal bezoeken en dat hierbij economische belangen van de patiênt geen of slechts een ondergeschikte rol spelen. Binnen de onderzoekspopulatie van de modellen $A$ en $B$ hebben de tijdbestedingsgroepen 1 en 4 minder dan gemiddeld kans op een dergelijk contact, terwijl groep 5 meer dan gemiddeld kans op een dergelijk contact heeft.

In bijlage 6 zijn tabellen opgenomen van de gemiddelden (getransformeerd) en de standaardafwijkingen van de variabelen die in de verschillende schattingsmodellen gebruikt zijn.

\subsection{RESULTATEN}

In deze paragraaf worden in eerste instantie de resultaten besproken van de geschatte varianten van model $I$, waarin de kans op een huisartsconsult op eigen initiatief verklaard wordt. Vervolgens komen de schattingsresultaten van de diverse varianten van model II aan de orde, waarbij het gaat om de kans op een huisartsconsult niet op eigen initiatief.

\subsubsection{Huisartsconsulten op eigen initiatief}

In variant A van model I wordt getoetst of de benodigde tijd van de referentiegroep een significant effect op de kans op een consult op eigen initiatief heeft. Daarnaast wordt getoetst of de benodigde tijd voor de overige onderscheiden groepen een effect heeft dat significant verschilt van het effect van de referentiegroep. Als referentiegroep is gekozen de groep die bestaat uit de personen werkzaam zijn als direkteur, zelfstandige, meewerkend in eigen bedrijf of free-lancers, allen met een werkweek van minstens 40 uur (tijdbestedingsgroep 2). Verondersteld wordt dat deze groep een relatief hogere tijdswaardering heeft dan alle andere groepen (zie paragraaf 2.4.). Dientengevolge wordt er een negatief effect van de benodigde tijd voor deze groep op de medische consumptie verwacht. Van alle andere groepen wordt een effect van de benodigde tijd verwacht dat lager ligt dan de referentiegroep (zie tabel 2.3.). Zoals uit de in tabel 3.3. 
gepresenteerde schattingsresultaten blijkt, worden deze verwachtingen over het algemeen bevestigd. Voor de referentiegroep heeft de benodigde tijd inderdaad een significant negatief effect op de kans op een consult op eigen initiatief. De coëfficiènten van alle interactieve tijuswariabelen hebben een positieve waarde, hetgeen per saldo betekent dat het effect van de benodigde tijd voor deze groepen tendeert relatief lager te liggen dan voor de referentiegroep. Uitzondering hierop vormt het teken van de coefficient van de interactieterm van groep 5 , dat negatief is. De verschillen met de referentiegroepen zijn echter alleen significant voor de groepen 1 en 6. Dit impliceert dat aangenomen mag worden dat voor de overige groepen de benodigde tijd geen ander effect heeft dan voor de referentiegroep.

In model $1 \mathrm{~B}$, waarin de benodigde tijd voor alle groepen interactief is opgenomen, wordt getoetst of de benodigde tijd voor de betreffende groep een significant effect op de kans op een consult op eigen initiatief heeft. Dit blijkt het geval te zijn voor de groepen $2,3,4$ en 5 . Voor groep 3, de groep die in model I A een niet significant verschillende effect van de benodigde tijd ten opzichte van de referentiegroep vertoonde, is de coefficient significant op het niveau, waarbij $0,05 \leq p \leq 0,10$. Voor de groepen 1 en 6 wordt het verwachte negatief effect van de benodigde tijd niet bevestigd.

Indien deze resultaten met de in paragraaf 2.3. geformuleerde verwachtingen vergeleken worden dan valt het volgende op. Het effect van de benodigde tijd voor de referentiegroep wordt overtroffen door het effect van deze variabele voor groep 5 , de niet-actieven. Voor de eerste groep werd het sterkste effect van tijd verwacht en voor de laatste groep het zwakste. Het feit dat voor deze laatste groep, die voor haar inkomen niet afhankelijk is van betaalde arbeid, toch een zo relatief sterk effect van de benodigde tijd gevonden wordt, zou erop kunnen wijzen dat voor deze groep de tijdsbesteding zelf verbonden is met negatieve nutseffecten. Dit lijkt een aannemelijke veronderstelling omdat van deze groep $55 \%$ binnen een WAO- of AAW regeling valt en derhalve verwacht mag worden dat met name het reizen voor dit deel van de groep extra moeite met zich meebrengt. Daarnaast kan deze sterke negatieve samenhang van tijd voor deze groep veroorzaakt worden door het gegeven dat deze groep een alanmerkelijk grotere kans op een consult niet op eigen initiatief heeft dan de rest van de onderzoekspopulatie, waardoor de kans op een consult op eigen initiatief eveneens afneemt. Een volgend opmerkelijk resultaat is dat voor de voor de groep full time loontrekkers geen significant effect van de benodigde tijd gevonden wordt. We komen hierop bij de bespreking van de resultaten van model I $\mathrm{C}$ terug.

Terwijl in de modellen I A en I B een relatieve waardering van de benodigde tijd tussen groepen plaatsvindt, wordt in model I C de benodigde tijd individueel gewaardeerd op basis van de loonvoet. Dit model is geschat voor die deelpopulatie die een (bekend) inkomen uit arbeid heeft. De samenstelling van de deelpopulatie op basis waarvan model I $\mathrm{C}$ geschat is als volgt: $73 \%$ van deze deelpopulatie behoort tot groep $1,5 \%$ tot groep 2 en $22 \%$ tot groep 6 . Uit de schattingsresultaten van de model I C blijkt dat de tijdprijs het verwachte negatieve en een significant effect op de kans op een consult op eigen initiatief heeft. Het is opmerkelijk dat de individueel gewaardeerde tijj well een effect heeft, terwijl de ongewaardeerde tijd voor de tijdbestedingsgroepen 1 en 6 , die $95 \%$ van de schattingspopulatie van model I $\mathrm{C}$ uitmaken, geen effect heeft. Hierop wordt nog teruggekomen. Hierna wordt vervolgd met de bespreking van de waargenomen samenhangen van de overige variabelen. 

hullsartsconsulten op elgen Inlliatlet

(t-waarden tussen haakjes)

\begin{tabular}{|c|c|c|c|}
\hline Verklarende variabelen & MODEL I A & MODEL I 8 & MODEL I C \\
\hline Benodigde tija (b) & $-0.1533(-2.44)$ & & \\
\hline Tijdprijs (b) & & & $-0.2103(-2.26)$ \\
\hline \multicolumn{4}{|l|}{ Benodigde tijd (b) $x:$} \\
\hline (1) full-time Loontrekkers (a) & $0.1302(3.19)$ & $-0.0231(-0.45)$ & \\
\hline \multicolumn{4}{|l|}{ (2) Full-time directeuren en } \\
\hline zelfstandigen (a) & & $-0.1533(-2.44)$ & \\
\hline (3) voll. in huish. met kind (a) & $0.0635(1.45)$ & $-0.0897(-1.69)$ & \\
\hline (4) Scholieren of studenten (a) & $0.0172(0.33)$ & $-0.1361 \quad(-2.27)$ & \\
\hline (5) Niet-actieven (a) & $-0.0430 \quad(-0.85)$ & $-0.1963(-3.36)$ & \\
\hline (6) Res tgroep (a) & $0.1025(2.43)$ & $-0.0507(-0.98)$ & \\
\hline Afstand ziekenhuis (b) & $-0.0674(-1.49)$ & $-0.0674(-1.49)$ & $0.0145(0.19)$ \\
\hline Niet (geh.) verzek. h.a. (a) & $-0.0354(-0.96)$ & $-0.0354 \quad(-0.96)$ & $0.0809(1.16)$ \\
\hline Inkomen & & & $-0.0014(-0.07)$ \\
\hline Loonvoet & & & $0.0546(0.12)$ \\
\hline Leeftijd & $-0.0006 \quad(-0.20)$ & $-0.0006(-0.20)$ & $-0.0035(-0.70)$ \\
\hline Gezondhelds toes tand (a) & $0.3075(7.96)$ & $0.3075(7.46)$ & $0.4704(6.22)$ \\
\hline Langdurige aandoentingen (b) & $0.3389(3.71)$ & $0.3389(3.71)$ & $0.2860(1.80)$ \\
\hline Vrouwen $18-45$ j r. (a) & $0.3170(8.04)$ & $0.3170(8.04)$ & $0.4309(7.34)$ \\
\hline Dagen belemm. activiteit (a) & $0.4762(10.14)$ & $0.4762(10.14)$ & $0.4350(5.59)$ \\
\hline opleiding & $-0.0541(-1.42)$ & $-0.0541(-1.42)$ & $-0.1063(-1.52)$ \\
\hline Contact telefoon/visite (a) & $-0.2025(-2.21)$ & $-0.2025(-2.21)$ & $-0.0682(-0.44)$ \\
\hline Constante & $0.0686(0.24)$ & $0.0686(0.24)$ & $0.9089(2.28)$ \\
\hline N & 6008 & 6008 & 2082 \\
\hline \multicolumn{4}{|c|}{ predictieve waarde van de voorspelling: } \\
\hline wel consult (c) & $49 \%(18 \%)$ & $49 \%(18 \%)$ & $50 \%(18 \%)$ \\
\hline geen consult (c) & $76 \%(6 \%)$ & $76 \% 16 \%$ & $78 \%(11 \%)$ \\
\hline Entropiemats taf & 0.038 & 0.038 & 0.062 \\
\hline Log likel thood & -3483.7 & -3483.7 & -1215.5 \\
\hline
\end{tabular}

(a): Betreffende variabele is een dumy-variabele.

(b) : Betreffende variabele is logaritmisch getransformeerd.

(c): Tussen haakjes is de winst aan predictileve waarde ten opzichte van de apriori kans opgenomen. 
De coèfficiènt van de variabele afstand heeft in de modellen I A en I B een negatief teken, echter deze bereikt net niet het significantiecriterium. Dit wijst in de richting van de verwachting dat huisartsconsulten op eigen initiatief en poliklinische hulp (deels) als complementen functioneren. In model I $\mathrm{C}$ wordt deze verwachting op generlei wijze bevestigd. De dummy-variabele voor het niet (geheel) verzekerd zijn heeft in geen van de modellen een significant effect op de kans op een consult op eigen initiatief. Ten aanzien van noch het inkomen noch wan de tijdprijs voor een alternatieve tijdsbesteding worden er in het $\mathrm{C}$-modlel significante effecten gevonden.

Leeftijd heeft in tegenstelling tot de overige indicatoren voor gezondheidstoestand geen significante betekenis. De variabelen die betrekking hebben op de eigen perceptie van de gezondheidstoestand, het aantal langdurige aandoeningen en of men in de afgelopen 14 dagen belemmerd was in zijn activiteiten, hebben allen een positief signifcant effect. Vrouwen in de leeftijd van $18 \mathrm{t} / \mathrm{m} 45$ jaar hebben een significant grotere kans op een consult op eigen initiatief. Hoewel de coëfficiënt van opleiding het verwachte negatieve teken heeft, wordt deze in geen van de modellen significant. De dummy-variabele die aangeeft of er sprake was van contact met de huisarts middels telefoon of bij de patiènt thuis heeft het verwachte negatieve teken en is significant in de modellen $A$ en B.

In tabel 3.4. worden de effecten van de benodigde tijd op de kans op een huisartsconsult weergegeven in de vorm van elasticiteiten. Deze zijn per tijdbestedingsgroep berekend (zie voor berekeningswijze bijlage 4). Daarnaast is de tijdprijselasticiteit op basis van model $\mathrm{C}$ berekend. Niet voor de referentiegroep maar voor de groep niet-actieven wordt de hoogste elasticiteit gevonden, te weten $-0,50$. Voor de referentiegroep wordt een elasticiteit van $-0,43$ gevonden, voor de groep scholieren en studenten bedraagt deze $-0,39$ en voor huisvrouwen met de zorg voor een kind $-0,21$. Voor de overige tijdbestedingsgroepen werden statistisch niet significante coëfficiënten gevonden (zie tabel 3.2.). De op basis van model $\mathrm{C}$ berekende tijdprijselasticiteit bedraagt $-0,34$. 
ticiteit wan groep:

Full-time Loontrekkers (1)

Full-time directeur/zelfst. (2) $\quad-0,43$

Huisvrouwen met kind (3) $\quad-0,21$

Schol i eren en studenten (4) $-0,39$

Niet actieven (5) $\quad-0,50$

Restgroep (6)

rijdprijselasticiteit

$-0,34$

a)

Effecten zijn weergegeven indien de geschatte coëffictënt significant van nul verschilt bij ps 0,10 .

Wanneer we de gevonden effecten van benodigde tijd en de tijdprijs met elkaar vergelijken dan valt op dat in de modellen I A en I B geen significante effecten van de interactie term voor de groepen 1 en 6 worden gevonden. Eerder is opgemerkt dat dit vragen oproept omdat deze groepen $95 \%$ van de deelpopulatie uitmaken waarop de schatting van model I $\mathrm{C}$ is gebaseerd. Op grond van dit laatste model wordt op basis van een significante coëfficiënt een elasticiteit ten opzichte van de met de loonvoet gewaardeerde tijd berekend van $-0,34$. Cruciaal is nu de vraag waardoor deze verschillen in uitkomsten tussen de modellen $A$ en $B$ enerzijds en model $C$ anderzijds veroorzaakt kunnen worden. De volgende faktoren kunnen een rol spelen:

1) Op de eerste plaats vindt in het model I $\mathrm{C}$ de tijdswaardering op individueel niveau plaats, waardoor de variatie in deze variabele relatief groter wordt. In de modellen I A en I B wordt de benodigde tijd middels de interactie term op groepsniveau "gewaardeerd" waardoor de variatie van de betreffende variabele niet toeneemt. Dit leidt ertoe dat de mate van samenhang in de modellen I $A$ en I B ten opzichte van die in mode! I $C$ lager zal uitvallen.

2) Een andere factor heeft betrekking op de wijze waarop de modellen gespecificeerd zijn. In de modellen I A en I B is de variabele benodigde tijd interactief opgenomen, terwijl in model I $\mathrm{C}$ niet de tijdprijs maar alle andere variabelen interactief worden, dat wil zeggen het specifieke effect weergeven voor die groepen die deel uitmaken van de schattingspopulatie. In model I $\mathrm{C}$ zijn dat de groepen 1, 2 en 6 (groep 3, 4 en 5 niet). Dit "interactief" worden van de overige variabele in model I $\mathrm{C}$ komt tot uitdrukking in een verschuiving van de waarden van de coëfficiënten van de variabelen die eveneens in de modellen I A en I B zijn opgenomen.

3) Daarnaast kan dit resultaat beïnvloed worden door de wijze waarop de tijdswaardering in de diverse modellen plaatsvindt. In feite vindt er in de modellen I A en I B een relatieve waardering van de benodigde tijd plaats. Deze verschillen kunnen een uitdrukking zijn van de som van monetaire en nietmonetaire nutseffecten, terwijl de waardering in model I $C$ alleen op basis van de monetaire nutseffecten van de alternatieve tijdsbesteding plaats vindt. Het is 
op basis wan de beschikbare data niet mogelijk om uitspraken te doen over de richting waarin de uitkomsten hierdoor beinvloed worden. Cauley (1987), die de marginale tijdprijs afleidde van de marginale geldprijs, vond een tijdswaardering die in de buurt lag van het uurloon. Hij concludeert op grond hiervan dat de som van de meetfowten die optreden bij een tijdswaardering op grond van het uurloon elkaar blijkbaar compenseren en per saldo klein zijn of in de buurt van nul liggen.

4) Een vierde factor die met name bij de eerste twee modellen een rol kan spelen is gelegen in eventuele verschillen tussen de tijdbestedingsgroepen, die tot uitdrukking komen in variabelen waarvoor in het schattingsmodel niet (volledig) gecorrigeerd wordt. Indien deze ontbrekende variabelen effect hebben op medisch consumptie kan het nu waargenomen effect van de interactieve tijdbestedingsvariabelen hierdoor beïnvloed zijn. Het bovenstaande maakt duidelijk dat de elasticiteiten berekend op basis van de modellen I A en I B niet zonder meer vergeleken kunnen worden met die berekend op basis wan de modlel $1 \mathrm{C}$.

Tot slot zijn in tabel 3.3. de predictieve warden van de modellen weergegeven. De predictieve waarde geeft aan welk percentage van de gevallen waarbij het model voorspelt dat de respondent bijvoorbeeld geen consult had, dit in werkelijkheid ook zo was (Sacket e.a., 1985, p. 76-80). Uit de berekende waarden blijkt dat de modellen I A en I B indien deze cen consult voorspellen in $49 \%$ van de gevallen het bij het rechte einde hebben en indien deze geen consult voorspellen in $76 \%$ van de gevallen ${ }^{1}$. Model I $\mathrm{C}$ is qua voorspellingskracht enigszins adequater in het voorspellen van consulten zoals wit de entropiemaatstaf blijkt. Deze entropiemaatstaf werd door Shannon (1949) gedefinieerd om de informatiewaarde te beoordelen van een mededeling van een gebeurtenis, waarvan de kans op een optreden ervan bekend is. Deze maatstaf verwijdert zich van nul naarmate een mededeling informatiever is ${ }^{2}$. Het is overigens evident dat deze modellen een beperkte voorspellingskracht hebben, hetgeen niet uitzonderlijk is wanneer deze gebaseerd zijn op individuele gegevens en gericht zijn op het voorspellen van individueel gedrag.

\subsubsection{Huisartsconsulten niet op eigen linitiatief}

In het vervolg worden de schattingsresultaten gepresenteerd en besproken van de modellen, waarin de effecten van tijd en de tijdprijs op de kans op een contact niet op eigen initiatief worden getoetst. De resultaten staan in tabel 3.5. weergegeven. Hieruit blijkt op basis van model II $\mathrm{A}$ dat de benodigde tijd geen statistisch significant effect op de consumptie van de referentiegroep heeft. Tevens blijkt voor geen van de tijdbestedingsgroepen een significant verschil van het effect van de benodigde tijd ten opzichte van de referentiegroep. De resultaten van model II B tonen dat er voor geen enkele tijdbestedingsgroep sprake is van een significant effect van de benodigde tijd op de kans op huisartsconsulten niet op eigen initiatief. Tot slot wordt op basis van model II $\mathrm{C}$ eveneens geen significant verschil van de tijdprijs vastgesteld. Wel hebben de coëfficiënten van de hiervoor genoemde variabelen het verwachte negatieve teken.

De variabele afstand tot het ziekenhuis heeft hoewel niet significant een positief teken, wat wijst op de in paragraaf 2.3. genoemde veronderstelling dat consulten niet op eigen initiatief substituten zijn voor speciallistcontacten. Het feit dat de als geldprijs opgevatte dummy-variabele voor het niet geheel verzekerd zijn voor de huisarts in het model II 
Tabel 3.5. Fesultaten loglstische regressle-analyse ter verklaring van de vraag naar hullsartsconsulten niet op elgen initiatief

(t-waarden tussen haakjes)

Verklarende variabelen

Benodigde tijid (b)

Tijdprijs (b)

Benodigde $t i j d(b) x$ :

(1) Full-time loontrekkers (a)

(2) Full-time directeuren en

zelfistandigen (a)

(3) Voll. in huish. met kind (a) $0.0885(1.32)$

(4) Scholieren en studenten (a) $-0.0135(-0.15)$

(5) Niet-actieven (a)

(6) Restgroep (a)

Afstand ziekenhuis (b)

Niet(geh.) verzek. (a)

Inkonen

Loonvoet

Hui sartsendich theid

Leeftijd

Gezondheids toes tand (a)

Langdurige aandoeningen (b)

Vrouwen 18-45jr. (a)

Dagen belemm. activiteit (a)

Opleiding

contact telefoon/visite (a)

constante

MODEL II A

$-0.1136(-1.18)$

$0.0303(0.42)$

$0.0061(0.09)$

$0.0550(0.80)$

$-0.1815(-3.06)$

$0.2624(4.16)$

$0.3288(5.57)$

$-0.1962(-1.48)$
$0.0822(1.28) \quad-0.0314(-0.41)$

$-0.1136(-1.18)$

$-0.0251(-0.32)$

$-0.1271(-1.25)$

$-0.0833(-1.01)$

$-0.1076(-1.39)$

$0.0550(0.80)$

$-0.1815(-3.06)$

$0.0482(0.39)$

$-0.1301(-1.14)$

$-0.0194(-0.61)$

$-0.3694(-0.50)$

$0.2424(0.22)$

$0.6565(1.13)$

$0.0200(4.32)$

$0.0207(2.72)$

$0.4631(4.72)$

$0.4107(7.19)$

$0.5716(4.71)$

$0.8775(4.21)$

$0.2624(4.16)$

$0.3048(3.28)$

$0.3288(5.57)$

$0.1794(1.73)$

$0.0318(0.55)$

$0.0595(0.56)$

$-0.1962(-1.48)$

$-0.2150(-0.93)$

$-3.0948(-6.38)$

$-2.9009(-3.93)$

$N$

6008

6008

2082

predictieve waarde van de voorspelling:

wel consult (c)

geen consult (c)

$23 \%$ (13\%)

$93 \%(4 \%)$

Entropienats taf

0.033

Log likel thood

$-1820.3$

$23 \%(13 \%)$

$93 \%(4 \%)$

0.033

$-1820.3$
$24 \%(15 \%)$

$94 \%(3 \%)$

0.033

(a): Betreffende variabele is een dumy-variabele.

(b): Betreffende variabele is logaritmisch getransformeerd.

(c): Tussen haakjes is de winst aan predictfeve warde ten opzlichte van de apr lor 1 kans opgenomen. 
A/B wel een significant negatief effect heeft in tegenstelling tot de modellen $I$, wijst in de richting dat deze variabele mede het $z g n$. zelfselectie-effect meet (Van de Vliet en Van de Ven, 1984). Dit houdt in dat juist die groep particulier verzekerden zich niet volledig verzekert, die voor zichzelf de kans klein acht in het medisch circuit verzeild te raken. Personen die niet (geheel) verzekerd zijn voor de huisarts hebben $14 \%$ minder kans, ceteris paribus, op een consult niet op eigen initiatief ten opzichte van personen die volledig verzekerd zijn. Noch het inkomen, noch de indicator voor de tijdprijs van de alternatieve tijdsbesteding, het inkomen per minuut heeft een significant effect.

De variabele huisartsendichtheid, opgenomen om een eventucel aanbodeffect op deze niet door de patiênt geïnitieerde vraag te toetsen, heeft wel het verwachte teken ${ }_{s}$ echter geen significant effect. Van der Zee (1982, p. 144), die eveneens geen effect van de huisartsendichtheid vindt stelt dat het aggregatieniveau van deze variabele waarschijnlijk te hoog is voor het vaststellen van een relatie. Eigenlijk zou men iemands contact met de huisarts in verband moeten brengen met de omvang van de praktijk van zijn eigen huisarts en niet met een geaggregeerd gemiddelde voor de gemeente waar iemand woont.

De variabelen die betrekking hebben op gezondheidstoestand hebben allen een significant positief effect op de kans op een consult niet op eigen initiatief. Hierbij valt op dat leeftijd naast de overige indicatoren voor de gezondheidstoestand nu wel een significant effect heeft in tegenstelling tot de modellen I. Gezien de gevonden effecten van de benodigde tijd en tijdprijzen op de kans op een consult niet op eigen initiatief blijft hier een berekening van elasticiteiten verder achterwege.

\subsection{BESPREKING EN CONCLUSIES}

Uit de in dit hoofdstuk gepresenteerde resultaten blijkt dat voorzover er tijdprijseffecten vastgesteld kunnen worden deze voornamelijk een rol spelen bij huisartsconsulten op eigen initiatief. In de modellen waarbij de waardering plaatsvond middels een interactievariabele die betrekking had op de hoofdbezigheid van het betreffende individu werden voor 4 van de 6 onderscheiden tijdbestedingsgroepen significante effecten van de benodigde tijd op de kans op een huisartsconsult op eigen initiatief gevonden. De elasticiteiten varieerden van $-0,21$ tot $-0,50$. Voor de twee grootste tijdbestedingsgroepen, de full-time loontrekkers en de restgroep kon op deze wijze geen effect van de benodigde tijd vastgesteld worden. In het model, waarin de benodigde tijd gewaardeerd wordt op basis van de loonvoet en dat geschat is op een deelpopulatie die voor $95 \%$ bestaat uit personen die tot de laatste 2 genoemde tijdbestedingsgroepen behoren, wordt een significant negatief effect wan de tijdprijs op de kans op een consult op eigen initiatief gevonden. De op basis hiervan berekende elasticiteit bedraagt $-0,31$.

Uit het feit dat van de tijd(prijs) geen effect voor consulten niet op eigen initiatief kan worden vastgesteld, blijkt dat dit door o.a. Feldstein (1974) en Wilensky en Rossiter (1981) voorgestelde onderscheid zeer van belang is bij het schatten van individuele vraagfuncties. Dit onderscheid blijkt met name ook relevant te zijn om effecten van eigen betalingen vast te stellen. Het verwachte negatieve effect hiervan wordt alleen bij consulten niet op eigen initiatief bevestigd.

Hierna worden de gevonden resultaten vergeleken met die van andere studies. In een onderzoek naar het effect van afstand en reistijd op huisartscontacten vindt van 
Sonsbeek (1984) een significant negatief effect van reistijd op het totaal van de consulten bij de huisarts thuis (eerste- en herhalingsconsulten samen). In dezelfde studie wordt geen effect van reistijd op het aantal contacten gevonden indien ook visites door de arts bij de patiënt thuis en telefonisch contacten worden meegenomen. Bij de visites door de arts bij de patiënt thuis wordt een positief verband met reistijd gevonden. Deze resultaten bevestigen het belang van het onderscheid tussen de aard van het contact. Van Vliet en Van de Ven (1984) vinden in hun studies wel een negatief effect van de ongewaardeerde variabele "benodigde tijd" voor ziekenfondsverzekerden echter niet voor particulier verzekerden. Een vergelijking met deze resultaten wordt bemoeilijkt doordat in deze laatste studie het eerste contact in een periode van 3 maanden wordt opgevat als een contact op eigen initiatief en doordat er verder geen onderscheid naar de aard van het contact wordt gemaakt.

Acton (1973a) vindt in zijn studie voor de Amerikaanse situatie elasticiteiten voor reistijden op het aantal contacten bij een arts thuis, die varieren van $-0,25$ tot $-0,34$. Voor wachttijden vindt hij geen significante elasticiteit op deze consumptiecategorie.

In de studie van Wilensky en Rossiter (1981), waarin alleen modellen voor artsgeïnitieerde consulten worden geschat wordt in tegenstelling tot de studie van Acton wel een negatief effect van wacht- en behandeltijd op de kans op een door de arts geïnitieerd consult gevonden. Dit resultaat zou erop kunnen wijzen dat het van belang. is de benodigde tijd voor reizen, wachten en behandeling apart in de modellen op te nemen.

Concluderend kan gesteld worden dat de benodigde tijd- c.q. de tijdprijsfactoren zijn die in de situatie waarin de patiënt een keuze maakt om al of niet naar de huisarts te gaan het effect hebben van een prijs. Dit effect lijkt weg te vallen indien niet de patiënt maar een arts of specialist het initiatief tot het contact neemt. In dat geval wordt de kans op een consult voornamelijk beïnvloed door variabelen die een indicator zijn voor de gezondheidstoestand van het individu.

Noten

1) De predictieve waarden zijn op basis van onderstaande classificatie als volgt berekend:

\begin{tabular}{l|ccc}
\hline In werkelijkheid: & \multicolumn{4}{|c}{ Voorspellingen door het model: } \\
\hline & wel consult & geen consult & rij-totaal \\
\hline wel consult & $\mathrm{P}_{11}$ & $\mathrm{P}_{12}$ & $\mathrm{P}_{1}$ \\
geen consult & $\mathrm{P}_{21}$ & $\mathrm{P}_{22}$ & $\mathrm{P}_{2}$ \\
\hline kolom-totaal & $\mathrm{P}_{1}$ & $\mathrm{P}_{.2}$ & \\
\hline
\end{tabular}


Predictieve waarde van de voorspelling:

-"wel consult" $=\frac{\mathbf{P}_{\mathrm{T1}}}{\mathbf{P}_{\mathrm{A}}}$

- "geen consult" $=\frac{\mathrm{P}_{22}}{\mathrm{P}_{.2}}$

2) De predictieve waarden zijn bepaald bij een drempelwaarde (r) van $\hat{y}_{i}$ (de geschatte waarde van de afhankelijke variabele) waarbij de entropiemaatstaf maximaal is. Indien $y_{i}$ groter is dan de drempelwaarde wordt aangenomen dat het betreffende individu een consult heeft gehad, zoniet wordt aangenomen dat er geen sprake was van een consult:

$\hat{y}_{i}=\left[\begin{array}{l}0 \text { als } \Phi \leq r \\ 1_{\text {als }} \Phi>r\end{array}\right.$

Hierin $\Phi$ de geschatte waarde van de functie $\Phi\left(x_{i}, B\right)$ waarin $x_{1}$ de vektor van onafhankelijke variabelen is en $B$ de vektor van schattingscoëfficiënten.

De entropiemaatstaf $(H)$ van het model is bij verschillende drempelwaarden berekend met behulp van de volgende formule (Büttner, 1977):

$H=\sum_{i=1 j=1}^{2} \sum_{i j}^{2} \cdot{ }^{2} \log \frac{P_{i j}}{P_{i} P_{j}}$ 


\section{HET EFFECT VAN TIJDPRIJZEN OP HET GEBRUIK VAN MEDICIJNEN}

"There is no absolute relation in time between two events, but there is an absolute relation in space and time ${ }^{n}$ (Einstein)

\subsection{INLEIDING}

Op basis van een aantal buitenlandse empirische studies naar de effecten van eigen betalingen stelt Van de Ven (1983) dat uitgaven voor voorgeschreven medicijnen relatief prijsgevoelig zijn ten opzichte van andere vormen van medische consumptie. Indien we ervan uitgaan dat het aandeel van de tijdkosten in de totale kosten in vergelijking met andere vormen van medische consumptie niet substantieel kleiner is, mogen we een relatief hoge tijdprijsgevoeligheid van deze categorie van medische consumptie verwachten. Ten aanzien van effecten van tijdprijzen op het gebruik van medicijnen is relatief weinig onderzoek gedaan. In geen van de in hoofdstuk 1 aangehaalde empirische studies speelt medicijngebruik een rol. In Nederland hebben Van Vliet en Van de Ven (1982) in hun onderzoek naar verschillen in medische consumptie tussen ziekenfonds- en particulier verzekerden een tweetal modellen gespecificeerd waarin zij de kans op medicijngebruik voorgeschreven door de huisarts respectievelijk de specialist verklaren. Geurts e.a. (1985) specificeren eveneens een model voor de kans op medicijngebruik, voorwaar er sprake is van een huisartsencontact, in hun onderzoek naar effecten van samenwerking door artsen op medische consumptie. In de genoemde modellen werden echter geen explíciete tijdprijsvariabelen opgenomen. 
In hef worige hoofdstuk werd het onderscheid tussen consumptie op eigen initiatief en consumptie niet op eigen initiatief gehanteerd om de positie van de patient in het keuzeproces nader te bepalen. Bij gebruik van medicijnen wordt het onderscheid tussen medicijnen op recept en medicijnen niet op recept gemaakt. In figuur 4.1. is vereenvoudigd schematisch weergegeven tussen welke alternatieven iemand kan kiezen indien zij overweegt medicijnen in te zetten ter opheffing of verlichting van klachten (zie ook Jessen, 1974, p. 30 e.v.).

Figuur 4.1. Gedragsalternatieven bij medicijnen-consumptie

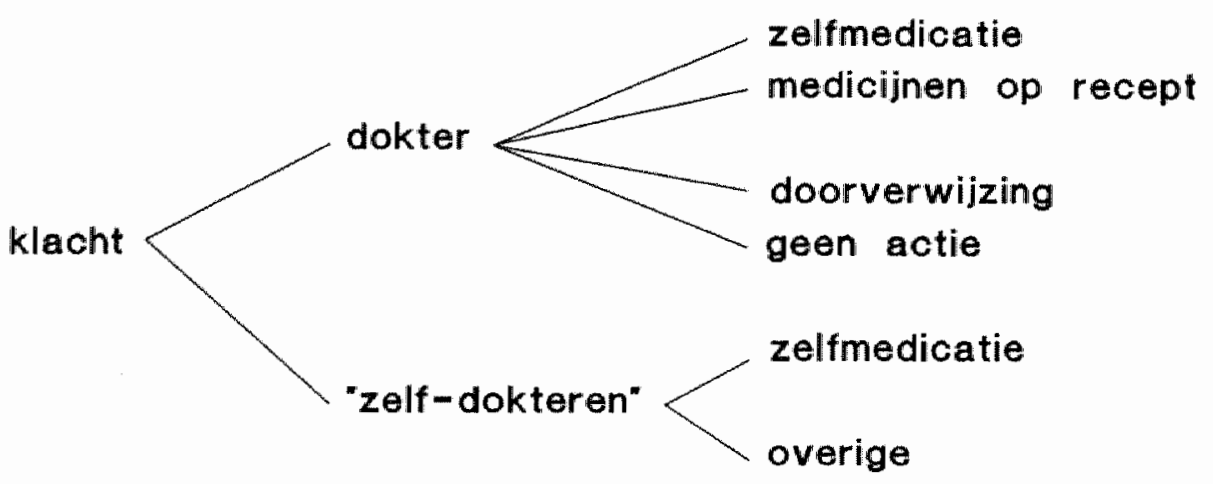

Bij zelfmedicatie koopt de gebruiker over het algemeen op grond van een eigen diagnose medicijnen, die zonder recept verkrijgbaar zijn. Hij vermijdt hierbij een bezoek aan de huisarts. De tijdprijs van een huisartsbezoek zal een positieve samenhang vertonen met de kans op gebruik van medicijnen niet op recept indien deze vorm van medische consumptie een substituut vormt voor medicijngebruik op recept. Overigens kan ook in geval van gebruik van medicijnen zonder recept contact met een arts hebben plaatsgevonden. Daarnaast wordt de keuze tussen medicijnen wel of niet op recept beperkt door het gegeven dat een groot aantal medicijnen eenvoudigweg niet zonder recept verkrijgbaar zijn. Tot slot ligt bij het voorschrijven van medicijnen het initiatief formeel bij de huisarts. Deze heeft overigens indien hij niet zelf apotheekhoudend is, geen directe financiele belangen heeft bij het al dan niet voorschrijven van medicijnen. Echter omdat verondersteld wordt dat hieraan voorafgaand de patiënt het initiatief heeft genomen om de huisarts te bezoeken, wordt er een negatief effect van de tijdprijs voor een huisartsconsult op het medicijngebruik op recept verwacht. Kortom het onderscheid tussen de kans op gebruik van medicijnen op recept en niet op recept heeft hier niet zozeer de betekenis om te corrigeren voor een eventueel aanbodeffect dan wel om het voorspelde differentiële effect van de (tijd)prijsvariabelen op beide consumptiecategorieën te toetsen. 
In paragraaf 4.2. worden de te gebruiken schattingsmodellen gespecificeerd en in paragraaf 4.3. worden de resultaten gepresenteerd. Hierbij wordlen afzonderlijk de modellen besproken voor medicijnen op recept en niet op recept. In de slotparagraaf worden de belangrijkste bevindingen samengevat.

\subsection{SPECIFICATIE VAN DE SCHATTINGSMODELLEN}

In principe kunnen er een drietal categorieën van medicijngebruik onderscheiden worden. De eerste twee categorieën hebben betrekking op respectievelijk door de huisarts of specialist voorgeschreven medicijnen. Dit gebruik gaat over het algemeen gepaard gaat met een contact met de huisarts respectievelijk de specialist. Deze waststelling is van belang voor de specificering van de tijd- en geldprijzen in de modellen. Het medicijngebruik op recept van de specialist wordt verder niet meer in de analyse betrokken. De reden hiervan is dat het aantal waarnemingen bij deze gebruikscategorie aan de lage kant is (minder dan $4 \%$ ), waardoor het aantal personen per tijdbestedingsgroep met dit type medicijngebruik te gering wordt voor een adequate analyse. Daarnaast is de benodigde tijd voor dit type medicijngebruik met het beschikbare databestand slechts op grove manier te benaderen, namelijk door middel van de afstand tot het dichtsbijzijnde ziekenhuis. De derde categorie die onderscheiden wordt heeft betrekking op gebruik van medicijnen die niet zijn voorgeschreven door een arts. Het gaat hierbij om geneesmiddelen die verkrijgbaar zijn zonder recept van de arts.De genoemde categorieën zijn in de modellen opgenomen als dummy-variabelen, waarvan de gemiddelde waarde de kans op medicijngebruik uitdrukt. Deze kans heeft betrekking op medicijngebruik in een periode van 14 dagen voorafgaand aan de enquête.

De eerste categorie van medicijngebruik waarvan in dit hoofdstuk de samenhang met tijdprijzen onderzocht wordt is medicijngebruik voorgeschreven door de huisarts (model III). Daar over het algemeen hiervoor contact met de huisarts nodig is, wordt verwacht dat de tijdprijsvariabelen die betrekking hebben op een huisartscontact een negatieve samenhang zullen vertonen. Van de geldprijsvariabele die betrekking hebben op het al of niet volledig verzekerd zijn voor medicijnen voorgeschreven door de huisarts en voor contacten met de huisarts wordt eveneens een negatief effect verwacht. Daar er op grond van de resultaten van de modellen voor huisartsconsulten geen eenduidige conclusies getrokken konden worden ten aanzien van de aard van relatie (complementair of substitueerbaar) tussen de kans op een huisartsconsult en op een specialistcontact, worden er hier geen verwachtingen uitgesproken ten aanzien van de richting van eventuele kruisprijseffecten. Om de aanwezigheid van een kruisprijseffect voor deze consumptiecategorie te toetsen komen een tweetal variabelen in aanmerking. Een eventuele kruistijdprijs wordt benaderd met de variabele afstand tot het dichtsbijzijnde ziekenhuis. Deze variabele is in het model opgenomen. Een tweede mogelijk kruisgeldprijseffect zou met behulp van de variabele al of niet (geheel) verzekerd voor medicijnen op voorschrift van de specialist gemeten kunnen worden. Deze laatste dummy-variabele moest uiteindelijk in verband met de grote samenhang met de dummy-variabele al of niet (geheel) verzekerd zijn voor medicijngebruik voorgeschreven door de huisarts uit het schattingsmodel verwijderd worden $(r=0,70)$. 
Wat betreft de prijsvariabelen is voor de verklaring van medicijngebruik zonder recept (model IV) geen eigen tijd- of geldprijs variabele beschikbaar. Vandaar dat hier slechts kruisprijzen in het model opgenomen kunnen worden. De aanname hierbij is dat de tijd- en geldprijzen van een huisarts- respectievelijk specialistcontact functioneren als kruisprijzen voor de kans op medicijngebruik zonder recept. De tweede aanname hierbij is dat medicijngebruik zonder recept deels een substituut is voor medicijngebruik op recept en derhalve positieve kruisprijseffecten verwacht kunnen worden.

Ten aanzien van een eventueel effect van de inkomensvariabele op medicijnen op recept van de huisarts kunnen hier dezelfde opmerkingen gemaakt worden als in paragraaf 3.2. Gezien de dominantie van het tijdprijseffect wordt hier geen zelfstandig inkomenseffect verwacht. De invoering van een eigen-bijdrage regeling voor ziekenfondspatiënten heeft plaats gevonden per 1 februari 1983 (Van den Berg, 1983), zodat voor ziekenfondsverzekerden ten tijde van de verzameling van de hier gebruikte gegevens een geldprijs voor voorgeschreven geneesmiddelen over het algemeen niet aan de orde was. Daar er bij medicijngebruik niet op recept in alle gevallen sprake van een geldprijs is, kan er een inkomenseffect verwacht worden. Aannemende dat het niet om een inferieur goed gaat wordt er een positief effect verwacht. Van de aanbodvariabellen wordt er op deze gebruikscategorie geen zelfstandig effect verwacht. Ten aanzien van de yoorkeurvariabelen wordt een positief effect verwacht en van de efficiëntie variabele opleiding een negatief effect.

Wat betreft de aanbodvariabelen is er een dummy in model III opgenomen die de waarde 1 aanneemt indien de huisarts apotheekhoudend is. In dat geval wordt gezien het financieel belang van de huisarts een positief effect verwacht. Van Vliet en Van de Ven (1982) vinden in de hiervoor aangehaalde studie echter een significant negatief effect. $\mathrm{Zij}$ geven bij de bespreking van dit resultaat tevens aan dat er een vrij sterke samenhang is tussen deze dummy-variabele en de urbanisatiegraad van het woongebied van de gebruiker. Dat wil zeggen dat de apotheekhoudende huisartsen vooral gevestigd zijn in de zogenaamde plattelandsgemeenten. Kortom het door Van Vliet en Van de Ven gevonden effect zou tevens een tijdprijseffect kunnen herbergen. Van deze aanbodvariabele wordt geen effect verwacht van het medicijngebruik niet op voorschrift.

Van de gezondheidsvariabelen worden in beide modellen positieve effecten verwacht. Ten aanzien van de variabele opleiding wordt in beide modellen een negatief effect verwacht.

In de volgende paragraaf worden afhankelijk van de wijze waarop de tijdprijsindicatoren geoperationaliseerd zijn, analoog aan die in het vorige hoofdstuk, de schattingsresultaten van een drietal model-varianten gepresenteerd. In tabel 4.1. wordt een overzicht gegeven van de gemiddelde waarden van de afhankelijke en onafhankelijke variabelen voor zover deze niet in hoofdstuk 3 besproken zijn. In bijlage 6 is een overzicht opgenomen van de gemiddelden en standaardafwijkingen van alle variabelen per model.

Uit de in tabel 4.1. gepresenteerde gegevens blijkt dat van de tijdbestedingsgroepen 3 en $5(14 \%$ resp. $17 \%)$ een significant groter deel medicijnen op recept van de huisarts heeft voorgesehreven gekregen dan de totale onderzoekspopulatie van model A en B $(12 \%)$. Voor de tijdbestedingsgroepen 2 en 4 is dit deel significant kleiner (8\% resp. 
Tabell 41.

Comiddolden van de athankelljke en onathankelljke varlabalen per onderzoakopopulatie (Model III on IM

(de standaardfout van het gemiddelde is tussen haakjes varmeld)

\begin{tabular}{|c|c|c|c|c|c|c|c|c|}
\hline \multicolumn{2}{|l|}{ Onderzoekspopulatie: } & \multicolumn{6}{|c|}{ Hodel $A$ en $B$} & \multirow[t]{3}{*}{ Model C } \\
\hline \multirow[b]{2}{*}{ Variabele onschrif ving } & \multicolumn{7}{|c|}{ Tllabestedingsgroep: } & \\
\hline & Totaal & 1 & 2 & 3 & 4 & 5 & 6 & \\
\hline Medicijnen op recept. & 0.12 & 0.11 & 0.08 & 0.14 & 0.05 & 0.17 & 0.13 & 0.11 \\
\hline van de hull sarts (a) & {$[0.00]$} & {$[0.01]$} & {$[0.01]$} & {$[0.01]$} & {$[0.01]$} & {$[0.02]$} & {$[0.01]$} & {$[0.01]$} \\
\hline Medicijnen niat op & 0.18 & 0.16 & 0.12 & 0.21 & 0.12 & 0.17 & 0.22 & 0.19 \\
\hline recept hultsarts (a) & {$[0.01]$} & {$[0.01]$} & {$[0.02]$} & {$[0.01]$} & {$[0.01]$} & {$[0.023$} & {$[0.01]$} & {$[0,01]$} \\
\hline Apotheekhoudende & 0.25 & 0.23 & 0.32 & 0.27 & 0.24 & 0.24 & 0.24 & 0.22 \\
\hline huil sarts(a) & {$[0.011$} & {$[0.01]$} & {$[0.02]$} & {$[0.01]$} & {$[0.02]$} & {$[0.02]$} & {$[0.01]$} & {$[0.01]$} \\
\hline Niet geh. verz. & 0.25 & 0.20 & 0.48 & 0.27 & 0.38 & 0.08 & 0.25 & 0.23 \\
\hline medic. huisarts (a) & {$[0.01]$} & {$[0.01]$} & {$[0.03]$} & {$[0.01]$} & {$[0.02]$} & {$[0.01]$} & {$[0.01]$} & {$[0.01]$} \\
\hline
\end{tabular}

(a): Betreffende variabele is en dumy-variabelte.

$5 \%$ ). De kans op medicijnen niet op recept is significant groter voor de tijdbestedingsgroepen 3 en 6 (21\% resp. $22 \%$ ) dan voor de totale onderzoekspopulatie van modellen $A$ en $B(18 \%)$. Ook voor deze consumptiecategorie hebben de tijdbestedingsgroepen 2 en 4 een significant kleinere kans (beide 12\%). De tijdbestedingsgroepen 1 en $\mathbf{5}$ onderscheiden zich wat betreft de kans op het gebruik van medicijnen niet op recept niet van de gemiddelde kans van de gehele onderzoekspopulatie van de modellen A en B.

Tussen de onderzoekspopulaties van de modellen A en B enerzijds en van model $C$ anderzijds zijn er geen significante verschillen in de gemiddelde waarden van de twee te verklaren variabelen. Van de verklarende variabelen worden hierna de gemiddelde frequenties besproken voorzover deze niet in hoofdstuk 3 aan de orde zijn geweest. Van tijdbestedingsgroep 2 heeft een aanmerkelijk groter deel (32\%) dan van de totale onderzoekspopulatie van de modellen A en B (25\%) een huisarts met een eigen apotheek. Bij de overige tijdbestedingsgroepen wordt geen significant verschil voor deze variabele vastgesteld. Binnen de onderzoekspopulatie van model $\mathrm{C}$ heeft $22 \%$ van de personen een huisarts met een eigen apotheek.

Van de tijdbestedingsgroepen 2 en 4 is respectievelijk $48 \%$ en $38 \%$ niet geheel verzekerd voor medicijnen op voorschrift van de huisarts, terwijl dit percentage voor de totale onderzoekspopulatie van de modellen $A$ en $B$ op $25 \%$ ligt. Bij de tijdbestedingsgroepen 1 en 5 ligt dit percentage significant lager (20\% resp. $8 \%$ ). Voor de onderzoekspopulatie van model $\mathrm{C}$ ligt dit met $23 \%$ niet significant lager dan voor de totale onderzoekspopulatie van de modellen $\mathrm{A}$ en $\mathrm{B}$. 


\subsection{RESULTATEN}

\subsubsection{Medicijnen op recept}

In deze deelparagraaf zullen achtereenvolgens de resultaten besproken worden van de geschatte varianten wan model III. In alle varianten van dit model is de kans op het gebruik van medicijnen voorgeschreven door de huisarts de te verklaren variabele. De drie varianten hebben achtereenvolgens, analoog aan de in het vorige hoofdstuk gehanteerde benadering betrekking op:

Modell III $A_{*}$ waarbij getoetst wordt in hoeverre de benodigde tijd van de diverse tijdbestedingsgroepen een significant verschillend effect heeft ten opzichte van die wan de referentiegroep. Ook nu weer is groep 2 als referentiegroep genomen (zie par. 2.4.).

Model III B, door middel waarvan getoetst wordt of en in welke mate de benodigde tijd van elke tijdbestedingsgroep afzonderlijk een significant van nul verschillend effect heeft.

Model III $C$. In dit model is de benodigde tijd op individueel niveau gewaardeerd op basis van de loonwoet. De populatie waarop de schatting betrekking heeft is hierbij gereduceerd tot diegenen die een eigen inkomen uit arbeid verdienen en waarvan dit ook op basis van de enquete bekend is. Middlels dit model wordt getoetst of en in welke mate de individuele tijdprijs een effect heeft op medicijngebruik op voorschrift van de huisarts.

De schattingsresultaten van de hierboven genoemde drie modellen worden weergegeven in tabel 4.2 .

Uit de schattingsresultaten van model III A blijkt dat er voor de referentiegroep een significant negatief effect van de benodigde tijd op de kans op medicijnen op voorschrift van de huisarts wordt gevonden. Voor geen van de tijdbestedingsgroepen blijkt de interactie-variabele voor benodigde tijd significant te zijn. Alleen voor tijdbestedingsgroep 3 wordt een bij $\mathrm{p} \leq 0,10$ significant positief verschil gevonden ten opzichte van de referentiegroep. Dit betekent dat voor deze groep de benodigde tijd een minder sterk effect tendeert te hebben dan voor de referentiegroep.

De resultaten van model III B laten zien dat er voor alle tijdbestedingsgroepen een signilicant effect van de benodigde tijd voor een huisartsenbezoek op de kans op het gebruik van medicijnen op recept gevonden wordt. Een kanttekening hierbij is dat de schattingscoëfficient van tijdbestedingsgroep 3 significant is bij $p \leq 0,10$. De coefficiénten van alle tijdbestedingsgroepen hebben het verwachte negatief teken.

De schattingsresultaten van het model III $C$ laten eveneens een significant negatief effect van de tijdprijs zien. Op basis van deze resultaten kan gesteld worden dat de in paragraaf 4.2. geformuleerde verwachtingen ten aanzien van tijdprijseffecten in alle varianten van Model III bevestigd worden. Met dien verstande dat er tussen de tijdsbestedingsgroepen geen differentiële effecten van de benodigde tijd ten opzicht van de referentiegroep gevonden wordt met uitzondering voor groep 3 . Na de bespreking van de rol van de overige variabelen zal op basis van berekende elasticiteiten op de omvang van de hier gevonden tijdprijseffecten worden teruggekomen. 
Tabel 4.2.

Resultaten loglstische regressib-analyse ter verklaring van het mediclingebruk op recept hulsarts

(t-waarden tussen haakjes)

Verklarende variabelen

MODEL III A

MODEL III B

MODEL III C

Benodigde tijd (b)

$-0.2536(-2.71)$

Tijdprijs (b)

$-0.5083(-3.49)$

Benodigde tijal(b) $x$ :

(1) Full-time loontrekkers (a) $\quad 0.0689(1.09) \quad-0.1847 \quad(-2.47)$

(2) Full-time directeuren en

zelfistandigen (a)

$-0.2536(-2.71)$

(3) Voll. in huish. met kind (a)

$0.1206(1.82)$

$-0.1330(-1.76)$

(4) Scholiteren en studenten (a)

$-0.0039(-0.04)$

$-0.2575(-2.67)$

(5) Niet-actieven (a)

$0.0370(0.52)$

$-0.2166(-2.71)$

(6) Restgroep (a)

$0.0548(0.85)$

$-0.1989(-2.67)$

Afstand $z$ iekenhuis (b)

$-0.0849(-1.16)$

$-0.0849(-1.16)$

$-0.1188(-0.89)$

Niet (geh.) verzekerd

medicijnen huisarts (a)

$-0.1570(-2.71)$

$-0.1570(-2.71)$

$-0.2276(-1.95)$

$0.0445(1.41)$

Inkonen

$0.9497(1.33)$

Loonvoet

Apotheekhoudend huisarts (a)

$-0.0334(-0.59)$

$-0.0334 \quad(-0.59)$

$-0.1332(-1.24)$

Leef $t i j d$

$0.0130(2.98)$

$0.0130(2.98)$

$0.0155(2.08)$

Gezondheidstoestand (a)

$0.2576(4.60)$

$0.2576(4.60)$

$0.2586(2.56)$

Langdurige aandoeningen (b)

$0.5244(4.45)$

$0.5244(4.45)$

$0.4763(2.21)$

Vrouwen $18-45 \mathrm{j} \mathrm{r}$. (a)

$0.0757(1.24)$

$0.0757(1.24)$

$0.1496(1.62)$

Dagen belemm, activiteit (a)

$0.6556(12.25)$

$0.6556(12.25)$

$0.8156(9.12)$

opleiding

$-0.0985(-1.76)$

$-0.0985(-1.76)$

$-0.1475(-1.40)$

Constante

$-1.1553(-2.90)$

$-1.1553(-2.90)$

$-1.0554(-1.84)$

N

5896

5896

2043

Predictieve waarde van de voorspelling:

wel gebruik (c)

$27 \%(16 \%)$

$94 \%(5 \%)$

geen gebrulk (c)

0.050

$94 \%(5 \%)$

$31 \%(20 \%)$

Entropienaatstaf

$-1905.4$

0.050

$94 \%$ (5\%)

Log Likel ihood

$-1905.4$

0.061

$-614.3$

(a): Betreffende variabele is een dumy-variabele.

(b): Betreffende variabele is logaritmisch getransformeerd.

(c): Tussen haakjes is de winst aan predictieve waarde ten opzichte van de aprifori kans opgenomen. 
De dummy-variabele, die de waarde 1 aanneemt indien men niet of niet geheel verzekerd is voor medicijngebruik op voorschrift van de huisarts heeft in alle in tabel 4.2. gepresenteerde modellen het verwachte negatieve teken en is significant. Ten aanzien van de variabele "afstand ziekenhuis" wordt het verwachte positieve kruisprijseffect niet bevestigd. Het overigens niet significante negatieve teken wijst in de richting van cen complementaire relatie met medicijnen op recept van de specialist. In het model III $\mathrm{C}$ wijst de coeffficiènt van de prijsvariabele die betrekking heeft op alternatieve tijdsbestedingen (de loonvoet) in de richting van het werwachte positieve kruisprijseffect. Deze bereikt echter niet het niveau van het gehanteerde significantiecriterium. De inkomens-variabele heeft in dit model dan wel het verwachte positieve teken, doch ook hier wordt geen significant effect gevonden.

De in de modellen III opgenomen aanbodvariabele, te weten een dummy-variabele die de waarde 1 aanneemt indien de huisarts van de respondent apotheekhoudend is, wijst in de richting van een negatieve samenhang met de kans op medicijngebruik op recept. Deze samenhang wordt echter in geen van de modellen statistisch significant. Dit resultaat bevestigt niet het gevonden resultaat in de reeds eerder aangehaalde studie van Van Vliet en Van de Ven (1982). Zij vinden een significant negatieve coëfficiẻnt voor deze dummy-variabele en merken hierbij op dat deze variabele nauw samenhangt met de urbanisatiegraad van de gemeente waarin de betreffende persoon woonachtig is. Het verschil met het hier gevonden resultaat zou veroorzaakt kunnen worden doordat de tijdprijsvariabele een eventueel afstandseffect in deze dummy-variabele wegneemt.

De variabelen met betrekking tot gezondheidstoestand hebben in alle hier beschouwde modellen de verwachte positieve en significante samenhang met de kans op medicijnen op recept van de huisarts. Uitzondering hierop is de dummy-variabele voor vrouwen in de leeftijd van 18 tot 45 jaar. Het feit dat pilgebruik niet tot medicijngebruik wordt gerekend, heeft uiteraard een dempende werking op een eventuele samenhang.

De variabele opleiding heeft het verwachte negatieve teken. In de modellen $A$ en $B$ is de coefficiënt van deze variabelen significant bij $\mathrm{p} \leq 0,10$. In model III $\mathrm{C}$ valt deze significantie verder terug $(p \leq 0,20)$.

In tabel 4.3. is de gevoeligheid weergegeven van de kans op medicijnen op voorschrift van de huisarts voor veranderingen in de tijd- en tijdprijsvariabelen door middel van elasticiteiten. De berekende elasticiteiten variëren van de $-0,41$ tot $-1,09$.

De tijdbestedingsgroepen 2 en 4 hebben relatief hogere elasticiteiten van benodigde tijd, namelijk $-0,82$ respectievelijk $-0,88$. De elasticiteiten voor de tijdbestedingsgroepen 1 , 5 en 6 hebben een gelijke orde van grootte met waarden van respectievelijk -0,62, 0,68 en $-0,63$. Voor tijdbestedingsgroep 2 wordt de geringste elasticiteit gevonden, te weten $-0,41$. De tijdprijselasticiteit die berekend is op basis van de gegevens van model C passeert de grens van -1 en bedraagt $-1,09$. 
Tabel 4.3. Elasticlteiten van de kans op gebruik van medicinen op voorschrift van de huisarts ten aanzien van tjd en tijdprijs")

Tijdelasticiteit van groep:

model III A en B

model III C

(1) Full-time loontrek.

$-0,63$

(2) Full-time dir/zelfst.

$-0,82$

(3) Huisvrouwen met kind

$-0,41$

(4) Scholieren en studenten

$-0,88$

(5) Niet actieven

$-0,68$

(6) Restgroep

$-0,63$

Tijdprijselasticiteit

$-1,09$

a) Effecten zijn weergegeven indien de geschatte coëfficiënt significant van nul verschilt bij $\mathrm{p} \leq 0,10$.

Wanneer we deze elasticiteiten vergelijken mel die voor de kans op een consult buj de huisarts op eigen initiatief (zie tabel 3.4.) dan valt op dat de in dit hoofdstuk berekende elasticiteiten aanmerkelijk hogere waarden hebben en hier in alle gevallen berekend zijn op basis van significante coefficiënten. Dit wijst er op dat huisartsconsulten die leiden tot het voorschrijven van medicijnen relatief tijjprijsgevoeliger zijn dan huisartscontacten waarbij dit niet gebeurt. Daarnaast is er tewens sprake van een significant effect van het niet (geheel) verzekerd zijn voor medicijnen op recept van de huisarts. De groep binnen de onderzoekspopulatie van model III $A / B$, die niet (geheel) verzekerd is, heeft ceteris paribus $15 \%$ minder kans op medicijnen op recept dan de groep die volledig verzekerd is voor deze consumptiecategorie. De vergelijkbare groep binnen de onderzoekspopulatie van model III $\mathrm{C}$ heeft $22 \%$ minder kans op medicijnen op recept van de huisarts. Deze resultaten bevestigen de aan het begin van dit hoofdstuk aangehaalde conclusie van Van de Ven dat uitgaven voor medicijnen op recept relatief prijsgevoelig zijn ten opzichte van andere vormen van medische consumptie.

\subsubsection{Medicljngebrulk nlet op recept}

In het vervolg van deze paragraaf worden de schattingsresultaten gepresenteerd die betrekking hebben op medicijngebruik niet op recept (model IV). Van dit model zijn op analoge wijze 3 varianten geschat. Zoals in paragraaf 4.2 . reeds is gesteld, is van deze variabele geen eigen tijd- of geldprijs bekend. Aangenomen wordt dat de tijd-en geldprijs voor medicijnen op recept functioneren als kruisprijzen en dat medicijnen niet op recept deels functioneren als substituten voor medicijnen op recept. Een overzicht van de schattingsresultaten wordt in tabel 4.4 . weergegeven. In model IV $A$ blijken de interactie-variabelen van de tijdbestedingsgroepen 1,3 en 6 significante positieve coëfficiënten te hebben. Dit lijkt te wijzen op het verwachte positieve kruisprijseffect. Immers de tijdvariabele van de referentiegroep blijkt geen significant effect te hebben evenalls die van de tijdbestedingsgroepen 4 en 5 . Uit de schattingsresultaten van model IV $B$ blijkt echter dat voor geen van de tijdbestedingsgroepen de benodigde tijd een effect heeft dat significant $(p \leq 0,10)$ van nul verschilt. In model IV $C$ wordt geen 
significant effect van de tijdprijs voor een huisartsenconsult op de kans op medicijnen niet op recept gevonden.

\section{Tabel 4,4. Fesultaten logistische regresalle-analyse ter verklaring van het medici|ngebrulk nllet op recept \\ ( $t$-waarden tussen haakjes)}

\begin{tabular}{|c|c|c|c|c|}
\hline Verklarende variabelen & MODEL & IV A & MODEL IV 8 & MODEL IV C \\
\hline Benodigde tijd (b) & -0.0775 & $(-1.01)$ & & \\
\hline Tijoprijs (b) & & & & $-0.0061 \quad(-0.87)$ \\
\hline \multicolumn{5}{|l|}{ Benodigde $t i j d(b) x$ : } \\
\hline (1) full-time Loontrekkers (a) & 0.1160 & $(2.25)$ & $0.0385(0.63)$ & \\
\hline \multicolumn{5}{|l|}{ (2) Full-time directeuren en } \\
\hline zelifstandigen (a) & & & $-0.0775(-1.01)$ & \\
\hline (3) Woll. in hullsh. met kind (a) & 0.1290 & $(2.38)$ & $0.0515(0.82)$ & \\
\hline (4) Scholieren en studenten (a) & 0.0380 & $(0.59)$ & $-0.0395(-0.54)$ & \\
\hline (5) Mlet-actfeven (a) & 0.0895 & $(1.47)$ & $0.0120(0.18)$ & \\
\hline (6) Res tgroep (a) & 0.1690 & $(3.23)$ & $0.0915(1.50)$ & \\
\hline Afstand ziekenhuis (b) & -0.0234 & $(-0,40)$ & $-0.0234(-0.40)$ & $0.0461(0.47)$ \\
\hline \multicolumn{5}{|l|}{ Niet (geh.) verzekerd } \\
\hline mediclijnan huisarts (a) & 0.0679 & $(1.57)$ & $0.0679(1.57)$ & $0.0497(0.62)$ \\
\hline Inkomen & & & & $0.0151(0.63)$ \\
\hline Loonvoet & & & & $0.7791(1.45)$ \\
\hline Apotheekhoudende huisarts (a) & -0.0743 & $(-1.63)$ & $-0.0743(-1.63)$ & $-0.1703 \quad(-2.12)$ \\
\hline Leeftijd & 0.0024 & $(0.68)$ & $0.0024(0.68)$ & $0.0055(0.93)$ \\
\hline Gezondhe ids toes tand (a) & 0.0523 & $(1.03)$ & $0.0522(1.03)$ & $-0.0100(-0.11)$ \\
\hline Langdurige aandoeningen (b) & 0.4086 & $(3.92)$ & $0.4086(3.92)$ & $0.4834(2.73)$ \\
\hline Vrouwen $18-45 \mathrm{jr}$. (a) & 0.2448 & $(5.29)$ & $0.2448(5.29)$ & $0.3794(5.65)$ \\
\hline Dagen bellemm. activiteit (a) & 0.2195 & $(4.16)$ & $0.2195(4.16)$ & $0.2303(2.67)$ \\
\hline Opleiding & 0.0534 & $(1.20)$ & $0.0534(1.20)$ & $0.0535(0.67)$ \\
\hline Constante & -1.6782 & $(-5,14)$ & $-1.6782(-5.14)$ & $-1.9503(-4.93)$ \\
\hline N & 5896 & & 5896 & 2043 \\
\hline \multicolumn{5}{|c|}{ Predictieve waarde van de voorspelling: } \\
\hline wel gebruik (c) & $24 \%$ & $(6 \%)$ & $24 \%(6 \%)$ & $27 \%(7 \%)$ \\
\hline geien gebrulk (c) & $86 \%$ & $(4 \%)$ & $86 \%(4 \%)$ & $86 \%(5 \%)$ \\
\hline Entroplenaats taf & 0.026 & & 0.026 & 0.034 \\
\hline Log likellithood & -2701.5 & & -2701.5 & -969.5 \\
\hline
\end{tabular}

(a): Betreffencle variabele is een dumy-variabele.

(b): Betreffende variabele is logaritmisch getransformeerd.

(c): Tussen haakjes is de winst aan predictieve waande ten opzichte van de apriori kans opgenomen. 
De dummy-variabele voor het niet (geheel) verzekerd zijn voor medicijnen op recept van de huissarts tendeert in de modellen IV A en IV $B$ een positief effect $(p \leq 0,20)$ te hebben op de kans op medicijnen niet op recept.

Dit resultaat lijkt een bevestignng van de bevindingen van Jessen $(1974$, p. 98 ) die vaststelde dat particulier verzekerden gemiddeld meer niet-voorgeschreven medicijnen in huis hebben. De groep die niet (geheel) verzekerd is blijkt, ceteris paribus, 6\% meer kans op medicijnen niet op recept te hebben. Het teken van de samenhangen met kruisprijswariabelen wijst in de richting van de aanname dat deze twee consumptiecategorieèn zich (deels) als substituten verhouden.

De dummy-variabele voor een huisarts met apotheek heeft in model $C$ cen significant negatief en in de modellen $A$ en $B$ bij $p \leq 0,20$ niveau significant negatief effect. Dit is een opmerkelijk gegeven, daar er in model III geen (positief) effect van deze dummyvariabele werd vastgesteld. Daar deze variabele samenhang vertoont met de urbanisatiegraad, kan dit negatieve effect ook een uitdrukking zijn van de bereikbaarheid van verkooppunten waar men medicijnen zonder recept kan krijgen. Deze variabele zou een indicatie kunnen zijn voor de eigen tijdprijs omdat de bereikbaarheid in landelijke gebieden over het algemeen minder zal zijn. Van Brekell (1987) stelt in een studie naar zelfmedicatie echter dat deze negatieve samenhang blijft bestaan undien men corrigeert voor urbanisatiegraad. Dit betekent dat bereikbaarheid niet de enige verklaring is voor de waargenomen negatieve samenhang met deze dummy-variabele. Verder onderzoek is hier op zijn plaats.

Noch de variabele leeftijd noch de eigen perceptie van de gezondheidstoestand blijken enig effect te hebben. Wel blijken personen met een langdurige aandoening en vrouwen in de leeftijd van 18 tot 45 jaar meer kans te hebben op medicijngebruik niet op recept. Dit geldt tevens voor personen die in de afgelopen 14 dagen belemmerd waren in hun activiteiten. Deze laatste bevindingen komen overeen met de uitkomsten van een onderzoek naar zelfmedicatie van Van Brekel (1983). Het opleidingsniveau blijkt nu in tegenstelling tot bij medicijnen op recept geen invloed te hebben. Tot slot blijken de schattingen van de modellen IV een aanmerkelijker geringer deel van met name de nul-waarden van de afhankelijke variabelen te kunnen verklaren dan de modellen III.

\subsection{CONCLUSIES}

De resultaten, die in dit hoofdstuk gepresenteerd werden, dat tijdprijzen voor een huisartsbezoek negatieve effecten hebben op de kans op medicijngebruilk op recept van de huisarts. De elasticiteiten variëren van $-0,41$ tot $-1,09$. Ten aanzien van de kans op het gebruik wan medicijnen niet op recept wordt voor geen enkele groep een kruisprijseffect gevonden van de benodigde tijd voor een huisartsbezoek. De geldprijswariabele heeft een negatief effect op de kans op medicijngebruik op recept in de modellen III A, B en C. De deelpopulatie in model III $A$ en $B$ die niet (geheel) verzekerd is heeft, ceteris paribus, $15 \%$ minder kans op medicijnen op recept dan de groep die geheel verzekerd is. Voor dezelfde groep binnen de schattingspopulatie van model III $C$ ligt dit percentage op $22 \%$. Deze variabele heeft een positief kruisprijseffect op medicijngebruik niet op recept in de modellen $\mathrm{V}$ A en $B$. Personen die niet (geheel) verzekerd zijn voor medicijnen op recept binnen de schattingspopulatie van model IV A/B hebben $6 \%$ meer kans op medicijnen niet op recept dan personen die wel geheel verzekerd zijn. 
Uit de vergelijking van de entropiemaatstaven blijkt dat de modellen ter verklaring van het medicijngebruik op recept beter het gedrag voorspellen dan de modellen ter verklaring van het medicijngebruik niet op recept. Over het algemeen blijkt de kans op medicifngebruik op recept van de huisarts gevoeliger te zijn voor zowel tijdprijzen en geldprijzen dan de kans op een huisartsconsult. Dit resultaat bevestigt de in de inleiding van dit hoofdstuk aangehaalde verwijzing naar een studie van Van de Ven (1983), die op grond van een viertal Amerikaanse studies vaststelt dat de consumptie van voorgeschreven medicijnen tendeert prijsgevoeliger te zijn dan die van andere vormen van medische consumptie. 
"Sinds de introductie van atoomklokken is de eenheid van tijd, de seconde, losgemaakt van de verschijnselen die zich aan de hemel afspelen." (Shallis, 1985)

\subsection{INLEIDING}

In paragraaf 2.3. is een schema opgenomen betreffende de structuur van het gezondheidszorgsysteem. Hieruit bleek dat er voor een patiënt twee manièren zijn om een eerste consult met de specialist te hebben. De eerste is zelf direct cen afspraak met de specialist maken. De tweede manier is op basis van een verwijzing van de huisarts een afspraak te maken. Ziekenfondsverzekerden moeten in alle gevallen een verwijskaart van de huisarts hebben en alleen particulier verzekerden kunnen afhankelijk van hun polisvoorwaarden zonder verwijzing van de huisarts op eigen initiatief een afspraak met een specialist maken. Wanneer in dit hoofdstuk de kans op een eerste specialistconsult word geschat, wordt aangenomen dat aan dit consult een huisartsconsult is voorafgegaan en dat de huisarts in formele zin besluit om een patient al of niet door te verwijzen. Op basis van deze aanname zal er een tijdprijs voor een dergelijk consult berekend worden.

Naast "eerste consulten" worden er in de Gezondheidsenquête zogenaamde herhalingsconsulten onderscheiden. Aangenomen mag worden dat deze in de meeste gevallen op initiatief van een specialist plaats vonden. In dit hoofdstuk zullen er afzonderlijke modellen gepresenteerd worden voor de kans op een eerste consult (Model V) en de kans op minstens eén herhalingsconsult met de specialist (Model VI). De periode waarop de waarnemingen betrekking hebben bedraagt drie maanden voorafgaand aan de enquête. Van beide modellen zullen, analoog aan de vorigen twee hoofdstukken, een drietal varianten geschat worden. 
In paragraaf 5.2. worden de modelspecificaties nader besproken. Vervolgens worden in paragraaf 5.3. de schattingsresultaten gepresenteerd en besproken. De samenvatting en conclusies zijn opgenomen in paragraaf 5.4 .

\subsection{SPECIFICATIE VAN DE SCHATTINGSMODELLEN}

In deze paragraaf zall eerst aandacht besteed worden aan de economische variabelen in beide modellen. Daarna komen de overige variabelen aan de orde.

Zoals in de inleiding reeds gesteld, wordt aangenomen dat aan elk eerste consult met de specialist een consult met de huisarts is vooraf gegaan. Op grond van deze aanname is er een benodigde tijd woor een eerste specialistconsult (model V) berekend op basis van een tweetal elementen. Het eerste element bestaat uit de benodigde tijd voor een huisartsconsult, zoals deze uit de enquête bekend is. Het tweede element bestaat uit de afstand (vice versa) tot het dichtsbijzijnde ziekenhuis, die vermenigvuldigd word met een tijdsfactor. Deze tijdsfactor bedraagt 2,5 minuut en is een arbitraire benadering voor de gemiddelde tijđ om een afstand van één kilometer te overbruggen. Door het ontbreken van gegevens over het soort vervoersmiddel en de feitelijke reistijd ten behoeve van een specialistenconsult, is de betekenis van deze gemiddelde tijdsfactor voornamelijk om de waargenomen afstand om te zetten in tijdseenheden. Sommatie van beide elementen levert de benodigde tijd voor een specialistconsult op. De op deze wijze berekende tijd bedroeg gemiddeld 73 minuten voor de schattingspopulatie van de modellen V A en B. Hiervan is gemiddeld 43 minuten nodig voor een huisartsconsult en 30 minuten voor reistijd naar de specialist en terug naar huis. Deze benadering impliceert dat wacht- en behandeltijden voor een specialistconsult niet zijn meegerekend. Deze beperking is opgelegd door het ontbreken van betreffende data in de enquête. In de interactie-variabele is de benodigde tijd woor een specialistconsult gekoppeld aan de dummy-variabele, welke aangeeft om welke tijdbestedingsgroep het gaat.

In model VI is de kans op minstens eén herhalingsconsult de afhankelijke variabele. In dit model wordt de tijdprijs benaderd door middel van de afstand tot het dichtsbijzijnde ziekenhuis. Dit betekent dat in de interactie-variabele de afstand gekoppeld is aan de dummy voor de betreffende tijdbestedingsgroep. In de C-varianten van model 5 en 6 worden de hiervoor genoemde benaderingen voor de benodigde tijd gewaardeerd met de loonvoet. Van de hierboven besproken tijdprijsvariabelen worden negatieve effecten verwacht op de kans op consumptie.

In beide modellen is als benadering voor de geldprijs de dummy-variabele opgenomen, die de waarde 1 aanneemt als men niet (geheel) verzekerd is voor specialistische hulp. Hiervan wordt eveneens een negatief effect verwacht. Een eventueel kruisprijseffect dat zou kunnen optreden in het geval men niet (geheel) verzekerd is voor de huisarts kan niet adequaat getoetst worden. Dit in verband met de hoge correlatie $(r=0,71)$ tussen beide variabelen. Dit kan betekenen dat het effect van de opgenomen variabelen hierdoor beinvloed wordt. Enige bedachtzaamheid bij de interpretatie van deze variabele is op zijn plaats.

De volgende twee variabelen zijn opgenomen in de $C$ varianten van beide modellen. Huishoudinkomen wordt opgenomen om een inkomenseffect te toetsen. Aannemende 
dat beide consumptiecategorieën een niet inferieur karakter hebben wordt een positief inkomenseffect verwacht. Het inkomen per minuut is in beide modellen opgenomen om te controleren voor een kruisprijseffect van een alternatieve tijdsbesteding. Hiervan wordt eveneens een positief effect verwacht.

In de modellen voor de kans op een eerste specialistconsult is de huisartsendichtheid als een aanbodvariabele opgenomen. Zoals in paragraaf 3.2 reeds besproken kan men op basis van de "target-income" hypothese bij grote praktijken een actiever verwijsgedrag van de huisarts verwachten. Op grond hiervan wordt er een negatief effect van de huisartsendichtheid op de kans op een eerste specialistconsult verwacht. In de modellen voor herhalingsconsulten is de specialistendichtheid als aanbodvariabele opgenomen. Aangenomen wordt dat deze consulten in alle gevallen geïnitieerd worden door een specialist. Eveneens op basis van de aanname dat specialisten een bepaald doelinkomen nastreven wordt verwacht dat een hogere specialistendichtheid een positief effect op de kans op minstens één herhalingsconsult zal hebben.

Naast de hierboven besproken economische variabelen is eenzelfde set variabelen als in de voorgaande modellen opgenomen met betrekking tot gezondheidstoestand. De verwachting ten aanzien van het effect van deze variabelen op de hier beschouwde consumptiecategorieën blijft eveneens positief. Tot slot is de variabele opleiding opgenomen. Van deze voorkeurvariabele wordt een negatief effect verwacht.

In tabel 5.1. wordt een overzicht gegeven van de gemiddelden en hun standaardfouten van de afhankelijke en de in dit hoofdstuk nieuwe onafhankelijke variabelen. Hieruit blijkt dat de onderzoekspopulaties van de $\mathrm{A} / \mathrm{B}$-modellen en model $\mathrm{C}$ een statistisch niet van elkaar verschillende kans op een eerste consullt met een specialist hebben van 0,08 respectievelijk 0,09 . Binnen de onderzoekspopulatie behorende bij het $\mathrm{A} / \mathrm{B}$-model heeft alleen groep 4 een significant lagere kans $(0,05)$ op een eerste consult met een specialist. Deze kans verschilt voor de overige tijdbestedingsgroepen niet significant van de totale onderzoekspopulatie van de A/B-modellen. Ten aanzien van de kans op een herhalingsconsult zijn de verschillen tussen de diverse onderzoekspopulaties groter. Voor de onderzoekspopulatie van model $C$ ligt deze kans met 0,13 net iets lager dan voor de onderzoekspopulatie van de A/B-modellen $(0,15)$. Dit geldt eveneens voor de tijdbestedingsgroepen 1,2 en 4 binnen de totale onderzoekspopulatie van de $A / B$ modellen met kansen van respectievelijk $0,12,0,09$ en 0,11 . De tijdbestedingsgroepen 3,5 en 6 hebben een grotere dan gemiddelde kans met waarden voor een kans op een herhalingsconsult van respectievelijk $0,17,0,25$ en 0,18 .

Wat de benodigde tijd woor een eerste consult met de specialist betreft zijn de verschillen tussen de onderzoekspopulaties niet zo groot. Tijdbestedingsgroep 4 heeft met 69,7 minuten minder tijd dan het gemiddelde van 73,1 minuten voor de totale onderzoekspopulatie nodig. De tijdbestedingsgroepen 3 en 5 zitten met respectievelijk 75,6 en 77,5 minuten hier iets boven. Verder blijkt wit het overzicht in tabel 5.1. dat van de onderzoekspopulatie wan de A/B-modellen zo'n 15\% niet (geheel) verzekerd is voor specialistische hulp. Dit percentage verschilt niet significant van het betreffende percentage $14 \%$ voor de onderzoekspopulatie van model $\mathrm{C}$ niet significant. Binnen de onderzoekspopulatie van de $\mathrm{A} / \mathrm{B}$-modellen is er van de tijdbestedingsgroepen 2 en 4 met respectievelijk $28 \%$ en $23 \%$ een significant hogere fractie niet (geheel) verzekerd voor deze consumptiecategorie in vergelijking met de fractie binnen de gehele onderzoekspopulatie (15\%). Binnen tijdbestedingsgroep 5 ligt dit percentage met $6 \%$ 
Tabel 5.1.

Cemiddelden van de afhankelljke en een aantal onathankelljke varlabelen per onderzoekspopulatio (Model V en Vi)

(de standaardfout van het gemiddelde is tussen halkjes opgenomen.)

\begin{tabular}{|c|c|c|c|c|c|c|c|c|}
\hline \multicolumn{3}{|l|}{ Onderzoekspopulat te: } & \multicolumn{5}{|c|}{ model $A$ en $B$} & \multirow[t]{3}{*}{ Model $\mathrm{c}$} \\
\hline \multirow[b]{2}{*}{ Variabele omschrijuing } & \multicolumn{7}{|c|}{ Ti jusbes ted ingsgroep: } & \\
\hline & Totaal & 1 & 2 & 3 & 4 & 5 & 6 & \\
\hline Kans op eerste contact & 0.08 & 0.08 & 0.07 & 0.08 & 0.05 & 0.07 & 0.09 & 0.09 \\
\hline met specialist (a) & {$[0.00]$} & {$[0.01]$} & {$[0.01]$} & {$[0.01]$} & {$[0.01]$} & {$[0.01]$} & {$[0.01]$} & {$[0.01]$} \\
\hline Kans op herhalings- & 0.15 & 0.12 & 0.09 & 0.17 & 0.11 & 0.25 & 0.18 & 0.13 \\
\hline contact met specialist (a) & {$[0.00]$} & {$[0.01]$} & {$[0.01]$} & {$[0.01]$} & {$[0.01]$} & {$[0.02]$} & {$[0.01]$} & {$[0.01]$} \\
\hline Benodigde tijd eerste & 73.09 & 71.91 & 74.64 & 75.61 & 69.71 & 77.53 & 72.40 & 72.03 \\
\hline contact met specialist (b) & {$[0.42]$} & {$[0.69]$} & {$[1.69]$} & {$[0.98]$} & {$[1,42]$} & {$[1.69]$} & {$[0.89]$} & {$[0.73]$} \\
\hline Niet (geh.) verzekerd & 0.15 & 0.13 & 0.28 & $0: 16$ & 0.23 & 0.06 & 0.15 & 0.14 \\
\hline specialistische hulp (a) & {$[0.00]$} & {$[0.01]$} & {$[0.02]$} & {$[0.01]$} & {$[0.02]$} & {$[0.01]$} & {$[0.01]$} & {$[0.01]$} \\
\hline \multirow[t]{2}{*}{ Special is tendicth the id } & 54.28 & 54.92 & 51.43 & 53.60 & 55.33 & 52.91 & 54.59 & 54.73 \\
\hline & {$[0.23]$} & {$[0.37]$} & {$[0.73]$} & {$[0.50]$} & {$[0.83]$} & {$[0.95]$} & {$[0.50]$} & {$[0.38]$} \\
\hline N & 5960 & 2182 & 361 & 1134 & 507 & 414 & 1362 & 2069 \\
\hline
\end{tabular}

(a): Betreffende variabele is een dumy-variabele.

(b): Waarden voor logari tmische transformatie.

aanmerkelijk lager en binnen tijdbestedingsgroep 1 ligt dit met $13 \%$ eveneens significant lager.

De verdeling van de variabele afstand die in de modellen voor de kans op een herhalingsconsult als een indicator voor de benodigde tijd functioneert is in tabel 3.2. (hoofdstuk 3) reeds besproken. Hieruit bleek dat de onderzoekspopulatie van model $\mathrm{C}$ met een gemiddelde van $5,8 \mathrm{~km}$ iets dichter bij een ziekenhuis woont dan de onderzoekspopulatie van de A/B-modelen $(6,1 \mathrm{~km})$. Binnen deze laatste onderzoekspopulatie wonen personen behorende bij de tijdbestedingsgroepen 2 en 3 met respectievelijk 7,2 en $6,6 \mathrm{~km}$ significant verder verwijderd van een ziekenhuis. De tijdbestedingsgroepen 4 en 6 wonen met 5,5 en $5,7 \mathrm{~km}$ gemiddeld iets dichterbij een ziekenhuis.

Ten aanzien van de specialistendichtheid kan er nauwelijks van verschillen tussen de diverse onderzoekspopulaties gesproken worden. Alleen personen behorende bij tijdbestedingsgroep 5 wonen in gebieden met een iets lagere specialistendichtheid, 
namelijk 52,9 in vergelijking met 54,3 specialisten per 100.000 inwoners woor de totale onderzoekspopulatie. Tot zover de bivariate statistiek.

\subsection{RESULTATEN}

\section{Tabell 5.2. Resultaten loglstlsche regressle-analyse tor verkllaring van de kans op een eerete speclallsticonsult \\ ( $t$ waarden tussen haakjes)}

\begin{tabular}{llll}
\hline Verkliarende variabelen MODEL $V A$ & MODEL V
\end{tabular}

Benodigde tijd le spec. contact (b) $0.1182(0.99)$

Tijdprijs le spec.contact (b)

$0.2986(1.71)$

Benodigde tijd $1^{\mathrm{e}}$ spec. contact (b) $x$ :
(11) Full-time loontrekkers (a)
$0.0238(0.44)$
$0.1420(1.28)$
(2) Full-time directeuren
en zelfstandigen (a)
$0.1182(0.99)$
(3) Volli, in huish. met kind (a)
$-0.0002(0.00)$
$0.1180(1.06)$
(4) Schol ieren en studenten (a)
$-0.0968(-1.27)$
$0.0214(0.17)$
(5) Niet-actieven
$-0.1006(-1.43)$
$0.0176(0.15)$
(6) Restgroep (a)
$0.0206(0.36)$
$0.1388(1.25)$
Niet (geh.) verzek. spec. (a)
$0.0414(0.59)$
$0.0414(0.59)$

$0.0367(0.29)$

Inkomen

Loonvoet

Huisartsen dichtheid

$-0.1770(-0.27)$

$-0.0075(-0.22)$

$-1.6242(-1.80)$

Leeftijd

$-0.0015(-0.30)$

$1.3308(1.15)$

Gezondheids toes tand (a)

$0.2962(4.42)$

$-0.1770(-0.27)$

$-0.0055(-0.67)$

Langdurige aandoeningen (b)

$0.2393(1.69)$

$-0.0015(-0.30)$

$0.3260(3.03)$

Vrouwen $18-45 \mathrm{j} r$. (a)

$0.0590(0.87)$

$0.2962(4.42)$

$0.6826(3.06)$

Dagen belenm. activiteit (a)

$0.5598(8.98)$

$0.2393(1.69)$

$-0.0320(-0.32)$

opleiding

$0.1293(2.11)$

$0.0590(0.87)$

$0.5902(6.02)$

cons tante

$-2.6684(-4.43)$

$0.5598(8.98)$

$0.2059(1.85)$

$0.1293(2.11)$

$-3.1570(-4.32)$

$\mathbb{N}$

5960

5960

2069

Predictieve waarde van de voorspelling:

wel consult (c)

$20 \%(12 \%)$

$20 \%(12 \%)$

$26 \%(17 \%)$

geen consult (c)

$94 \%(2 \%)$

$94 \%(2 \%)$

$94 \%(3 \%)$

Entropiemaats taf

0.020

0.020

0.030

Log likel ihood

$-1545.6$

$-1545.6$

$-557.8$

(a): Betreffende variabele is een dummy-variabele.

(b): Betreffende variabele is logaritmisch getransformeerd.

(c): Tussen haakjes is de winst aan predictieve waarde ten opzichte van de apriori kans opgenomen. 
In deze paragraaf zullen achtereenvolgens de resultaten besproken worden van model V en VI. In tabel 5.2. staan de schattingsresultaten weergegeven die behoren bij model $V$, waarin de kans op een eerste specialistconsult verklaard wordt.

\subsubsection{Ferste specialistconsult}

Uit de gepresenteerde gegevens van model $V A$ blijkt dat de benodigde tijd voor de referentiegroep een positieve samenhang vertoont. Deze is echter niet significant. Daarnaast heeft voor geen van de tijdbestedingsgroepen deze variabele een significant van de referentiegroep verschillend effect. Uit de resultaten wan model $V$ B blijkt dat voor geen enkele tijdbestedingsgroep de tijdsvariabele een significant van nul werschillend effect heeft. Het teken is in alle gevallen positief. Dit is een niet verwachte richting. De coéfficiènt van de tijdprijswariabele in model $\mathrm{C}$ heeft eveneens het onverwachte positief teken en is significant bij $0,10 \leq \mathrm{p} \leq 0,05$. Deze resultaten wijzen in de richting dat de wijze waarop de tijd(prijs)-variabele geoperationaliseerd is meer een kruisprijseffect weergeeft dat een eigen prijseffect. Hierop wordt nog terug gekomen.

De dummy-variabele voor het niet (geheel) verzekerd zijn heeft in geen van de type $\mathrm{V}$ modlellen een significant effect. Voor de aanbodvariabele huisartsenhdichtheid wordt in geen van de modellen een significant effect gevondien. Dit geldt eveneens voor de variabelen huishoudinkomen en loonvoet in model $\mathrm{V} \mathrm{C}$.

Van de gezondheidsindicatoren heeft leeftijd en de dummy-variabelle voor vrouwen in de leeftijd van 18 - 45 jaar geen significant effect. De dummy-variabele met betrekking tot de gezondheidsperceptie heeft well het verwachte positieve effect evenals de variabele die het aantal langdurige aandoeningen weergeeft.

Tot slot heeft de variabele opleiding in alle modellen een onverwacht positief en significant effect op de kans op een eerste specialistconsult. Uit de waarde van de entropiemaatstaf blijkt dat het model $\mathrm{V} C$ een enigszins betere verklaringskracht heeft dan de modellen V A en B. Op basis van de hier gepresenteerde resultaten kan geen bevestiging gevonden worden van de veronderstelling dat economische variabelen een significant effect hebben op deze consumptiecategorie.

\subsubsection{Herhalingsconsulten bij de specialist}

In hoeverre kan de laatste vaststelling eveneens voor de kans op een herhalingsconsult met de specialist gemaakt worden? De schattingsresultaten van de modellen die hierop betrekking hebben staan weergegeven in tabel 5.3. Uit de geschatte coëfficiènten van model VI A blijkt dat de afstand als een indicatie voor de benodigde reistijd een significant negatief effect heeft voor de referentiegroep. Het effect van deze variabele voor de overige tijdbestedingsgroepen tendeert hier positief van te verschillen. De coëfficiẻnten van de interactie-variabelen van de tijdbestedingsgroepen 3, 4, 5 en 6 verschillen significant van die van de referentiegroep $(p \leq 0,10)$.

Uit de resultaten van model VI B blijkt echter dat alleen voor de tijdbestedingsgroepen 1 en 2 afstand als indicator voor reistijd een significant van nul verschillend effect op de kans op een herhalingsconsult heeft. Voor de overige tijdbestedingsgroepen wordt er geen significant van nul verschillend effect vastgesteld, ook al heeft de coëfficiënt het 


\section{Tabel 5.3.}

Resultaten logletleche vegresele-analyee tor verklarling van de kane op en herhallngsconsult bl] de speclallst

( $t$-waarden tussen haakjes)

\begin{tabular}{|c|c|c|c|}
\hline Verklarende variabelen & MODEL VI A & WODEL VI B & MODEL VI C \\
\hline Afstand ziekenhuis (b) & $-0.3105(-2.60)$ & & \\
\hline Tijdprijs herh. spec.contact (b) & & & $-0.1843(-1.06)$ \\
\hline \multicolumn{4}{|l|}{ Afstand ziekenhuis (b) $\mathrm{x}$ : } \\
\hline (1) Full-time loontrekkers $(a)$ & $0.1574(1.41)$ & $-0.1530(-2.08)$ & \\
\hline $\begin{array}{l}\text { (2) Full-time directeuren en } \\
\text { zelfstandigen (a) }\end{array}$ & & $-0.3105(-2.60)$ & \\
\hline (3) Woll. in huish. met kind (a) & $0.2649(2.28)$ & $-0.0455(-0.61)$ & \\
\hline (4) Scholiteren en studenten (a) & $0.3289(2.32)$ & $0.0184(0.16)$ & \\
\hline (5) Niet-actieven (a) & $0.2236(1.77)$ & $-0.0868(-0.93)$ & \\
\hline (6) Restgroep (a) & $0.2347(2.06)$ & $-0.0758(-1.01)$ & \\
\hline Wlet (geh.) verzek. spec. (a) & $0.0283(0.50)$ & $0.0820(0.50)$ & $0.1059(0.84)$ \\
\hline Inkomen & & & $-0.0130(-0.12)$ \\
\hline Loonvoet & & & $0.5772(0.57)$ \\
\hline Special is tendich theid & $0.0072(3.25)$ & $0.0072(3.25)$ & $0.0108(2.82)$ \\
\hline Leeftijd & $0.0097(2.48)$ & $0.0097(2.48)$ & $0.0100(1.42)$ \\
\hline Gezondhe ids toes tand (a) & $0.4519(9.10)$ & $0.4519(9.10)$ & $0.4444(4.90)$ \\
\hline Langdurige aandoeningen (b) & $1.1588(11.05)$ & $1.1588(11.05)$ & $0.9726(5.11)$ \\
\hline Vrouwen $18-45 \mathrm{jr}$. (a) & $0.1788(3.34)$ & $0.1788(3.34)$ & $0.2666(3.18)$ \\
\hline Dagen belemerde activitelt (a) & $0.3518(6.60)$ & $0.3518(6.60)$ & $0.3538(3.88)$ \\
\hline opleiding & $0.0924(1.91)$ & $0.0924(1.94)$ & $0.1590(1.69)$ \\
\hline Constante & $-2.3598(-8.02)$ & $-2.3598(-8.02)$ & $-2.8127(-6.04)$ \\
\hline $\mathbb{N}$ & 5960 & 5960 & 2069 \\
\hline \multicolumn{4}{|c|}{ Predictiewe waarde van de voorspelling: } \\
\hline wel consult $(\mathrm{c})$ & $35 \%(20 \%)$ & $35 \%(20 \%)$ & $27 \%(14 \%)$ \\
\hline geen consult (c) & $92 \%(7 \%)$ & $92 \%(7 \%)$ & $93 \%(6 \%)$ \\
\hline Entroplemaats taf & 0.069 & 0.069 & 0.050 \\
\hline Log likel ihood & -2198.8 & -2198.8 & -515.7 \\
\hline
\end{tabular}

(a): Betreffende variabele is een dumy-variabele.

(b): Betreffende variabele is logaritmisch getransformeerd.

(c): Tussen haakjes is de winst aan predictieve waarde ten opzichte van de apriori kans opgenomen.

verwachte teken met uitzondering van groep 4.

Uit de resultaten van model VI C blijkt dat de op basis van de loonvoet gewaardeerde variabele afstand als benadering voor de tijdprijs wel de verwachte negatieve samenhang vertoond, echter deze is niet significant. De dummy-variabele voor het niet (geheel) verzekerd zijn voor specialistische hulp heeft in geen van de modellen een significant effect. Dit geldt eveneens voor het huishoudinkomen en de loonvoet in modell VI C. 
De aanbodvariabele specialistendichtheid laat in alle modellen een significant positief effect op de kans op een herhalingsconsult zien.

Leeftijd heeft in de modellen VI A/B een significant positief effect. In model VI $C$ is deze samenhang eveneens positief, maar niet significant. De overige gezondheidsindicatoren hebben in alle modellen het verwachte significante effect. De variabele opleiding heeft in de modellen VI A/B evenals bij de kans op een eerste consult een onverwacht positief effect $(p \leq 0,10)$. In model VI $C$ heeft deze variabele eveneens een positief teken ( $\mathrm{p} \leq 0,10)$.

Indien we de waarden van de entropiemaatstaf van de modellen voor een herhalingsconsult vergelijken met die voor een eerste consult dan blijken de eerstgenoemde modellen het feitelijk gedrag beter te kunnen voorspellen.

\subsection{Bespreking en conclusies}

Uit de in dit hoofdstuk gepresenteerde schattingsresultaten blijkt dat de benodigde tijd geen invloed heeft op de kans op een eerste specialistconsult en dat deze variabele alleen voor de tijdbestedingsgroepen 1 en 2 een significant negatief effect op de kans op een herhalingsconsult heeft. De tijdprijs blijkt voor de deelpopulatie met een inkomen uit arbeid zelfs een positief effect $(p \leq 0,10)$ te hebben op de kans op minstens eén eerste specialistenconsult. Deze variabele vertoont voor dezelfde deelpopulatie een negatieve niet significante samenhang met de kans op minstens én herhalingsconsult. Deze resultaten geven geen eénduidig beeld van de relatie tussen tijd(prijzen) en de hier beschouwde consumptiecategorieẻn.

Toch is het voorbarig om op basis van voorgaande resultaten de conclusie te trekken, dat deze samenhang in werkelijkheid niet aanwezig is en wel om de volgende reden. Op de eerste plaats is er sprake van een gebrekkige operationalisatie van de tijdsvariabele. Immers de werkelijke reis-, wacht- en behandeltijd voor een gerapporteerd specialistconsult zijn niet bekend. Als gevolg hiervan is het aannemelijk dat de variatie in de gebruikte variabele geringer is dan in werkelijkheid, waardoor de gevonden coëfficiënt in de richting van nul vertekend zal zijn. Uit een in 1984 gehouden onderzoek van Consumentenbonden in een ziekenhuis in Emmen bleek bijvoorbeeld dat de gemiddelde wachttijd van 688 patienten 17,8 minuten bedroeg (Werkgroep, 1984). Deze wachttijd bleek te variëren van minder dan 10 in $4 \%$ van de gevallen tot langer dan 30 minuten in $16 \%$ van de gevallen.

Op de tweede plaats impliceert de operationalisatie van de benodigde tijd in model $\mathrm{V}$ complementariteit tussen huisartsconsulten en een specialistconsulten. Zoals eerder gesteld is dit niet in alle gevallen aan de orde en functioneert voor een deel van de particulier verzekerden het specialistconsult als een substituut. Dit betekent dat de effecten van de twee elementen van de geconstrueerde tijdsvariabele niet in alle gevallen dezelfde richting opgaan. Ook hierdoor zal de waarde van de gevonden coëfficiënt in de richting van nul vertekend worden. Dominantie van specialistconsulten die feitelijk een substituut zijn voor huisartsconsulten zou verantwoordelijk kunnen zijn voor het positieve effect $(\mathrm{p} \leq 0,10)$ van de tijdprijs in model V C. 
op de derde plats is in beide modellen gebruik gemakikt van de variable afstand als benadering voor de reistijd. Herbi is de atstand op basis van postcodes van het wowndres wan de geënqueteerde persoon respectievelik het dichtsbijzijnde ziekenhas bepaald. Indien het specialistconsult niet in het dichtsbijzijnde tiekenhuis plaatswond

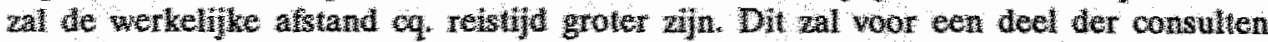
zeker zo zijn. Doordat de gebruike afstand en benadering wan de werkelikke astand is zal eveneens de waarde van de geschatte coeffititut in we richting wan nul vertekend zinn

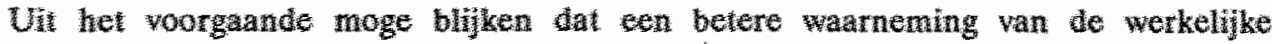
benodigde ijd op zijn pladts is akorens uitspraken te kunen doen over de werkelike betekenis van tijuprijen wor deze consumptiecategorież. Daarnaast wijst de studie van Wilensky en Rosster (1981) in de richting dat het relevant is om onderscheid te maken ussen cen antal soorten specialismen. Zij onderseheiden er een drietal. De eerste groep verleent wat ail noemen primaire zorg (bijwoorbeeld interne geneeskande, gynaecologie), de tweede groep verleent secundaire zorg (bijwoorbeeld de chirurgische specialismen, netrologie enz.). Onder de derde groep rangschikken aij specialsmen als dernatologie, psychiatrie enz. But de eerste en de latste categorie viaden rij significant negatiewe effecten van de wach-en behandeltijd op de kans op een consult geinitieerd door de speciahist. Acton (1973a) die in zijn studie geen verschil tussen soorten specialistsmen muald windt elasticiteiten variërend van $-0,62$ tot $-0,96$ van reistijd op het aandal poliklinische bezoeten. Howel de positie van poliklinische specialismen in de Verenigde Staten niet geheel vergelinkbaar is met die in Nedertand wijzen deze wuthomsten in de richting dat op zijn minst een gedeelte wan deze vorn van medische consumptie prijsgevoelig is.

Ten aanzien van de overige resultaten in dit hoofdstuk kan nog het volgende worden gezegd. Voor het niel (geheel) verzekerd zijn wed geen significant effect vastgesteld. Hot werwachte negatieve effect wan deze variabele zou gedempd kunnen zijn door het gegeven dat particulier verzekerden na multwariate correctie nog ca, $20 \%$ meer spectalistconsulten dan de ziekenfondsverzekerden hebben. Dit stelden Van Vliet en Van de Ven (1984) vast in hun studie naar verschillen tussen ziekenfonds en particulier verzekerden. Er werd bit de kans op een eerste consult geen aambodeffect van huisartsendichtheid vastgesteld. Wel werd er bij de kans op minstens een herhalingsconsult een significant positief effect van de specialistendichtheid vastgesteld. Op basis vän de geschatte coëfficiënten kan er een aanbodelasticiteit berekend worden van $+0,33$ op basis van modellen VI $A B$ en van $+0,52$ op basis van model VI C.

Tot slot werd hier in alle modellen een significant positief effect van de variabele opleiding vastgesteld. Dit in tegenstelling tot de negatieve effecten die op de in de hoofdstukken 3 en 4 beschouwde consumptiecategorieën werden vastgesteld. Dit verwachte positieve effect zou mede veroorzaakt kunnen worden doordat deze variabele sterk samenhangt met de loonvoet $(r=0,40)$ en met de niet opgenomen dummyvariabele voor het niet (geheel) verzekerd zijn voor de huisarts $(r=0,40)$. Van beide wordt een positief kruisprijseffect verwacht. 
Concluderend kan gesteld worden dat woor deze consumptiecategorieën verder onderzoek op basis van meer adequate gegevens over de werkelijke benodigde tijd en eventueel uiltgesplitst naar een aantal specialismen gewenst is teneinde beter gefundeerde uitspraken te kunnen doen over het effect van tijdprijzen. Zo ligt het voor de hand om aan te nemen dat in de Nederlandse situatie het gebruik van de zogenaamde poortspecialisten gevoeliger is voor variaties in niet-medische patiëntvariabelen dan het gebruik van de ondersteunende specialismen, zoals radiodiagmostiek, anesthesie (Schaaf, 1984). Ook hier is verder onderzoek op zijn plaats. 


\section{HET EFFECT VAN TIJDPRIJZEN OP OPNAME EN LIGDUUR IN HET ZIEKENHUIS}

"Juist de begrippen "vroeger" en "later" zijn uitingen van het menselijk vermogen om zich tegelijkertijd voor de geest te halen wat niet tegelijkertijd gebeurt". (Elias, 1985).

\subsection{INLEIDING}

Fuchs (1978) stelt in zijn studie naar aanbod-geïnduceerde vraag bij klinische chirurgie dat tijdkosten hierbij minder relevant zijn vanwege de relatief hoge psychische kosten van deze opnamen. Anderzijds stelt hij dat de tijdkosten van hospitalisatie over het algemeen hoog zijn in relatie tot de kosten van reizen en wachten bij poliklinische hulp. Opname in het ziekenhuis is eén van de meest tijdsintensieve vormen van hulpverlening in de gezondheidszorg. Tevens zijn de kosten van deze vorm van zorgverlening ook voor particulier verzekerden grotendeels of volledig verzekerd. Er mag dan ook verwacht worden, dat voorzover er economische factoren van invloed zijn op deze vorm van medische consumptie, de tijdprijs tot deze factoren behoort.

Het onderscheid tussen vraag- en aanbod-geïnitieerde klinische consumptie is niet zo eenvoudig te operationaliseren. Immers in alle gevallen vereist een opname in het ziekenhuis zowel de instemming van een arts als van de patiënt. In de periode dat de hier gebruikte data verzameld werden ging er van het financieringssysteem nog een stimulans uit op het maximaliseren van het aantal verpleegdagen. In een onlangs verschenen onderzoek van Van Vliet en Van Doorslaer (1987) naar de samenhang tussen aanbod en gebruik van bedcapaciteit stellen zij vraagtekens bij de bekende empirische wet van Roemer (1961): "A built bed is a filled bed". $\mathrm{Zij}$ vinden in tegenstelling tot menig eerder onderzoek geen significant effect van bedden- en specialistendichtheid op de opnamekans. Wel wordt er een aanbodeffect van de beddendichtheid op de gemiddelde ligduur gevonden (zie ook Van Vliet, 1988). In dit 
hoofdstuk wordt vooralsnog van de verwachting uitgegaan dat het aanbod de opnamekans én ligduur beïnvloedt.

In paragraaf 6.2. worden de modellen voor beide comsumptiecategorieến nader gespecificeerd. In paragraaf 6.3. worden de schattingsresultaten gepresenteerd en besproken. Dit hoofdstuk eindigt met een samenvatting en concluderende opmerkingen in paragraaf 6.4 .

\subsection{SPECIFICATIE VAN, SCHATTINGSMODELLEN}

Gezien de onzekerheid over de duur van een ziekenhuisopname is het niet mogelijk om op individueel niveau de tijdprijs voor een ziekenhuisopname vast te stellen. Het is echter wel mogelijk de tijdprijs van éen dag in het ziekenhuis te benaderen op basis van de alternatieve kosten. Voor die deelpopulatie die een inkomen uit arbeid geniet, is op basis van het gemiddeld aantal uren dat men per week werkt en onder de veronderstelling dat deze uren over 5 dagen gespreid zijn, de duur van een gemiddelde werkdag vastgesteld. Vervolgens is deze werkdag gewaardeerd met het inkomen per tijdseenheid (de loonvoet). Voor de betreffende populatie, die overeenkomt met die op basis waarvan de C-varianten van de voorgaande modellen geschat zijn, bedraagt de gemiddelde tijdprijs op deze wijze berekend $f 133,22$ per verpleegdag. De variantie in deze variabele wordt bepaald door zowel de variantie in de duur van de werkdag als door de waardering per tijdseenheid. De verwachting is dat deze variabele een negatief effect zal hebben op zowel de opnamekans als verpleegduur.

Voor de personen waarbij de tijdswaardering op basis van de loonvoet ontbreekt, is over het algemeen ook geen duur van de gemiddelde arbeidsdag bekend. Derhalve is het voor deze personen niet mogelijk om enige variantie in de opgeofferde tijd vast te stellen. Zodoende is het hier evenmin mogelijk om zoals bij de voorgaande consumptiecategorieën vast te stellen of de elasticiteit van de consumptie ten aanzien van de benodigde tijd per tijdbestedingsgroep varieert. Om toch na te gaan of er enige samenhang is tussen het behoren tot een tijdbestedingsgroep en de hier beschouwde medische consumptie worden er modelvarianten geschat, waarin dummy-variabelen zijn opgenomen voor het behoren tot een bepaalde tijdbestedingsgroep. Hierbij zal tijdbestedingsgroep 2 evenals in de eerder geschatte A-varianten als referentiegroep functioneren. Indien aangenomen wordt dat deze dummy-variabelen niet systematisch samenhangen met niet in het model opgenomen relevante variabelen, is significantie van de betreffende coefficięnt op te vatten als een indicator voor een relatief tijdprijseffect. Immers een positieve coefficiènt betekent dat de betreffende tijdbestedingsgroep grotere kans op medische consumptie heeft dan de referentiegroep. Aannemende dat het om een normaal goed gaat en alle overige variabelen constant houdend kan dit geinterpreteerd worden als een indicator voor een lagere tijdswaardering. Op basis van de in paragraaf 2.3. geformuleerde aannamen wordt verwacht dat de vijf overige tijdbestedingsgroepen onder constant houden van de overige variabelen meer kans op medische consumptie zullen hebben dan de referentiegroep. Dit komt overeen met positieve waarden voor de te schatten coëfficiënten van de dummy-variabelen.

De variabele afstand tot het dichtsbijzijnde ziekenhuis kan een tweetal effecten in zich herbergen. Deze is in de modellen opgenomen als een benadering van de reistijd voor een specialistcontact. Op grond hiervan kan er een positief kruisprijseffect verwacht 
worden, aannemende dat ziekenhuisopname en specialistcontacten deels substituten zijn. Daarnaast kan deze reistijd ook beschouwd worden als een element van de totale tijdprijs van een ziekenhuisopname. Hierbij kan gedacht worden aan de tijd benodigd voor een bezoek aan de patiënt. Met name bij de verklaring van de ligduur zou dit laatste effect wel eens kunnen optreden. Gezien het voorgaande ligt een cénduidige verwachting ten aanzien van het resulterende effect van deze variabele niet voor de hand.

Als een indicatie voor de eigen geldprijs is de dummy-variabele voor het niet (geheel) verzekerd zijn voor een ziekenhuisopname in de modellen opgenomen. Hiervan wordt uiteraard een negatief effect verwacht. In de modellen die geschat worden voor de deelpopulatie waarvan het inkomen bekend is, de C-varianten, wordt deze variabele opgenomen om te corrigeren voor een eventueel inkomenseffect. Eveneens wordt in deze modellen door opname van het inkomen per tijdseenheid (de loonvoet) gecorrigeerd voor een eventueel positief kruisprijseffect van alternatieve tijdsbestedingen.

Omdat beide consumptiecategorieën door hun aard beïnvloedbaar zijn door de aanbodzijde en deze in de beschouwde periode ook een eenduidig financieel belang hierbij had, worden in alle modellen indicatoren voor het beschikbare aanbod opgenomen. Deze indicatoren hebben betrekking op het aantal specialisten en bedden per 100.000 resp. 1.000 inwoners. De aanboddichtheden zijn vastgesteld voor 129 sociaal economische gebieden (zie voor een nadere omschrijving Hussen, 1982). Hoewel in de eerder aangehaalde studie van Van Vliet en Van Doorslaer alleen een significant effect van beddendichtheid op verpleegduur gevonden werd, blijft het relevant om deze variabelen in het model op te nemen om te voorkomen dat een eventueel effect van de variabele afstand hierdoor vertekend wordt. Gezien de specifieke kenmerken van de onderzoekspopulatie in de betreffende studie, alléén particulier verzekerden, en een groot aantal studies waarin wel een positief verband tussen aanbodniveau en consumptie werd vastgesteld (zie voor een overzicht van Van Vliet en Van Doorslaer, 1987) wordt hier vooralsnog een positief effect van de betreffende aanbodvariabelen verwacht.

Om te controleren voor effecten van leeftijd, geslacht en gezondheidstoestand zijn betreffende variabelen in het model opgenomen. Voor gezondheidstoestand is zowel de eigen perceptie als het aantal langdurige aandoeningen opgenomen. Tot slot is de variabele opleiding als een voorkeurindicator in de modellen opgenomen.

De in dit hoofdstuk te schatten modellen voor de gemiddelde verpleegduur zullen alleen op die populatie geschat worden, die in de waarnemingsperiode van éen jaar ook minstens éénmaal zijn opgenomen. In tabel 6.1. staan de gemiddelden en hun standaardfouten weergegeven van de afhankelijke en de voor dit hoofdstuk nieuwe onafhankelijke variabelen. Uit de gegevens in tabel 6.1. blijkt dat de onderzoekspopulatie van model VII $\mathrm{C}$ een lagere opnamekans $(0,05)$ heeft dan de onderzoekspopulatie van model VII A $(0,07)$. Binnen deze laatste onderzoekspopulatie hebben de tijdbestedingsgroepen 3,5 en 5 een significant hogere opnamekans, namelijk respectievelijk 0,09, 0,10 en 0,08. De tijdbestedingsgroepen 1, 2 en 4 hebben significant lagere opnamekansen dan de totale onderzoekspopulatie van model VII $\mathrm{A}$, te weten respectievelijk $0,05,0,03$ en 0,04 . 
Tabel 6.1.

Gemiddelden van de afhankelijke en aantal onafhankelijke vartabelen per onderzoekspopulatle (model vill)

(de standaardfout van het gemiddelde is tussen haakjes opgenomen..)

\begin{tabular}{|c|c|c|c|c|c|c|c|c|}
\hline \multicolumn{3}{|l|}{ Onderzoekspopulat te : } & \multicolumn{4}{|c|}{ Model VII A } & \multicolumn{2}{|r|}{ Model WII $C$} \\
\hline \multirow[b]{2}{*}{ Vartabelen } & \multicolumn{8}{|c|}{ Tijdbeis tedingsgraep: } \\
\hline & Totaal & 1 & 2 & 3 & 4 & 5 & 6 & \\
\hline Kans op z lokentius- & 0.07 & 0.05 & 0.03 & 0.09 & 0.04 & 0.10 & 0.08 & 0.05 \\
\hline name $(a)$ & {$[0.00]$} & {$[0.00]$} & {$[0.01]$} & {$[0.01]$} & 1] $[0.01]$ & {$[0.06]$} & {$[0.01]$} & {$[0.00]$} \\
\hline \multirow[t]{2}{*}{ Spectal is tendichtheid } & $\mathrm{d} 54.43$ & 54.99 & 51.52 & $53 i, 62$ & 55.39 & 53.15 & 54.66 & 54.77 \\
\hline & {$[0.23]$} & {$[0.37]$} & {$[0.72]$} & {$[0.50]$} & {$[0.83]$} & {$[0.97]$} & {$[0.50]$} & {$[0.38]$} \\
\hline \multirow[t]{2}{*}{ Beddendichtheid } & 4.18 & 4.17 & 4.18 & 4.22 & 4.25 & 4.13 & 4. $\| 4$ & 4.15 \\
\hline & {$[0.02]$} & {$[0.03]$} & {$[0.06]$} & {$[0.03]$} & {$[0.05]$} & {$[0.07]$} & {$[0.04]$} & {$[0.03]$} \\
\hline Niet geheel verz. & 0.12 & 0.09 & 0.25 & 0.12 & 0.19 & 0.04 & 0.12 & 0.11 \\
\hline z iekenhui sopname (a) & {$[0.00]$} & {$[0.01]$} & {$[0.02]$} & {$[0.01]$} & {$[0.02]$} & {$[0.01]$} & {$[0.01]$} & {$[0.01]$} \\
\hline$N$ & 5964 & 2187 & 364 & 1136 & 504 & 4.17 & 1356 & 2073 \\
\hline
\end{tabular}

(a): Betreffende variabele is een dumny-variabele.

Overigens ligı de in de Gezondheidsenquête geregistreerde opnamekans aanmerkelijk onder de gegevens die via landelijke registraties bekend zijn. Van Brekel (1985b) noemt onder andere de volgende oorzaken hiervoor. De Gezondheidsenquête bevat geen gegevens van patiënten, die in het ziekenhuis zijn overleden (30\%) of die na ontslag elders zijn opgenomen in verpleeghuizen e.d. (1\%). Daarnaast worden opnamen in verband met bevalling niet als zodanig geteld (ca. 12\%).

Het percentage personen met geen volledige verzekering voor een ziekenhuis-opname verschilt niet tussen de onderzoekspopulaties van beide modellen (ca. 11-12\%). Binnen de schattingspopulaties van model VII A ligt dit percentage voor de tijdbestedingsgroepen 2 en 4 met $25 \%$ respectievelijk $19 \%$ duidelijk hoger. Voor de tijdbestedingsgroepen 1 en 5 ligt dit percentage met $9 \%$ respectievelijk $4 \%$ significant lager in vergelijking met de gehele onderzoekspopulatie van model VII A. Ten aanzien van de beddendichtheid is er geen sprake van enige significante verschillen tussen de diverse populaties.

In tabel 6.2. zijn gemiddelden opgenomen van de afhankelijke en onafhankelijke variabelen van dat deel van de onderzoekspopulatie dat in het afgelopen jaar in een ziekenhuis was opgenomen. Hieruit blijkt dat de onderzoekspopulatie van model VIII A tendeert een langere gemiddelde verpleegduur (14,1 dagen) te hebben dan die van model VIII C (11,96 dagen). Binnen de onderzoekspopulatie van model VIII A blijkt dat personen behorende bij tijdbestedingsgroep 5 met een gemiddelde van ruim 23 


\section{Tabel 6.2.}

Gemididelden van de athankelljke an ean antal onathankelike varlabelen per onderzoekspopullatie (model Villi)

(de standaardfout van het gemiddelde is tussen haakjes opgenomen.)

\begin{tabular}{|c|c|c|c|c|c|c|c|c|}
\hline \multirow{3}{*}{$\begin{array}{l}\text { Onderzoekspopulatie: } \\
\text { Varíabelen }\end{array}$} & \multicolumn{6}{|c|}{ Model VIII A } & \multicolumn{2}{|c|}{ Model VIII 0} \\
\hline & \multirow[b]{2}{*}{ Totaal } & \multicolumn{6}{|c|}{$T \|$ dbes tedingsgroep: } & \\
\hline & & 1 & 2 & 3 & 4 & 5 & 6 & \\
\hline \multirow[t]{2}{*}{ Verpleegduur ziekenh. } & 14.10 & 12.87 & 8.89 & 13.50 & 8.86 & 23.20 & 13.70 & 11.96 \\
\hline & {$[1.00]$} & {$[1.35]$} & {$[2.23]$} & {$[1.70]$} & {$[1.72]$} & {$[5.70]$} & {$[1.62]$} & {$[1.28]$} \\
\hline \multirow[t]{2}{*}{ Geslacht (a) } & 0.59 & 0.14 & 0.22 & 1.00 & 0.4 .2 & 0.23 & 0.86 & 0.33 \\
\hline & {$[0.02]$} & {$[0.03]$} & {$[0.15]$} & {$[0.00]$} & {$[0.12]$} & {$[0.07]$} & {$[0,03]$} & {$[0.05]$} \\
\hline \multirow[t]{2}{*}{ Leeftijd } & 40.40 & 37.00 & 49.90 & 40.80 & 18.42 & 45.35 & 44.40 & 38.90 \\
\hline & {$[0.68]$} & {$[1.26]$} & {$[4.17]$} & {$[1.04]$} & {$[0.460]$} & {$[2.13]$} & {$[1.24]$} & {$[1.20]$} \\
\hline \multirow[t]{2}{*}{ Gezondhe ids toes tand (a) } & 0.46 & 0.44 & 0.56 & 0.40 & 0.37 & 0.70 & 0.43 & 0.38 \\
\hline & {$[0.03]$} & {$[0.05]$} & {$[0.18]$} & {$[0.05]$} & {$[0 . .11]$} & {$[0.07]$} & {$[0.05]$} & {$[0.04]$} \\
\hline \multirow[t]{2}{*}{ Langdurige aand. (c) } & 0.76 & 0.74 & 1.00 & 0.61 & 0.68 & 1.21 & 0.72 & 0.61 \\
\hline & {$[0.05]$} & {$[0.08]$} & {$[0.33]$} & {$[0.10]$} & {$[0.15]$} & {$[0.16]$} & {$[0.09]$} & {$[0.08]$} \\
\hline \multirow{2}{*}{$\begin{array}{l}\text { Niet (geh.) verzek. } \\
\text { ziekenhuis (a) }\end{array}$} & 0.10 & 0.04 & 0.22 & 0.12 & 0.16 & 0.07 & 0.14 & 0.06 \\
\hline & {$[0.02]$} & {$[0.02]$} & {$[0.15]$} & {$[0.03]$} & {$[0.09]$} & {$[0.04]$} & {$[0.03]$} & {$[0.02]$} \\
\hline \multirow[t]{2}{*}{ Afstand ziekenhuis (c) } & 5.80 & 5.94 & 7.24 & 6.51 & 6.61 & 5.23 & 4.95 & 6.51 \\
\hline & {$[0.23]$} & {$[0.42]$} & {$[1.95]$} & {$[0.42]$} & {$[1.33]$} & {$[0.62]$} & {$[0.45]$} & {$[0.45]$} \\
\hline \multirow[t]{2}{*}{ Specialis tendich theid } & 54.96 & 56.90 & 50.81 & 55.16 & 48.04 & 51.14 & 55.87 & 54.12 \\
\hline & {$[0.91]$} & {$[1.59]$} & {$[5,36]$} & {$[1.63]$} & {$[4.77]$} & {$[2.82]$} & {$[1.91]$} & {$[1.52]$} \\
\hline \multirow[t]{2}{*}{ Beddendichtheid } & 4.19 & 4.26 & 3.36 & 4.35 & 3.80 & 4.22 & 4.10 & 4.40 \\
\hline & {$[0.07]$} & {$[0.13]$} & {$[0.52]$} & {$[0.10]$} & $7[0.28]$ & {$[0.21]$} & {$[0.14]$} & {$[0.12]$} \\
\hline N & 396 & 109 & 9 & 105 & 19 & 43 & 111 & 102 \\
\hline
\end{tabular}

(a): Betreffende variabele is een dummy-variabele.

(c): Waarden vóór logaritmische transformatie. 
dagen een aanmerkelijk langere verpleegduur hebben dan de overige tijdbestedingsgroepen. De tijdbestedingsgroepen 2 en 4 hebben met een gemiddelde verpleegduur van 8,9 dagen een significant kortere verpleegduur dan de totale onderzoekspopulatie van model VIII A.

Vrouwen maken met $59 \%$ een beduidend groter deel van de onderzoekspopulatie van model VIII A uit dan van model VIII C (33\%). Binnen de tijdbestedingsgroepen 1,2 , 4 en 5 ligt het percentage vrouwen met $14,22,42$ en $23 \%$ onder het gemiddelde van de gehele populatie van model VIII A. Tijdbestedingsgroep 3 bestaat voor $100 \%$ wit vrouwen en groep 6 voor $86 \%$.

De onderzoekspopulaties van beide modellen verschillen niet qua leeftijd. De tijabestedingsgroepen 2,5 en 6 hebben met een gemiddelde van $49,9,45,3$ en 44,4 jaren een hogere leeftijd dan de onderzoekspopulatie van model VIII $A$ in haar geheel met 40,4 jaren.

Binnen de onderzoekspopulatie van model VIII A beoordeelt $46 \%$ zijn gezondheid anders dan "goed" (d.w.z. "gaat wel", "wissselend" of "slecht") tegenover 38\% binnen de onderzoekspopulatie van model VIII $C$. Binnen de eerstgenoemde populatie beoordelen personen behorende bij de tijdbestedingsgroepen 2 en 5 met respectievelijk $56 \%$ en $70 \%$ van de gevallen meer dan gemiddeld hun gezondheid anders dan "goed". Alleen tijdbestedingsgroep 4 ligt met een gemiddelde van $37 \%$ significant onder het gemiddelde van de gehele onderzoekspopulatie van model VIII A. Voor het gemiddelde aantal langdurige aandoeningen is een vergelijkbaar patroon waarneembaar.

Het percentage dat niet (geheel) verzekerd is voor ziekenhuiskosten tendeert in de onderzoekspopulatie van model VIII $\mathrm{C}$ met $6 \%$ lager te liggen dan voor de onderzoekspopulatie van model VIII A (10\%). Binnen deze laatste onderzoekspopulatie heeft alleen tijdbestedingsgroep 1 een significant geringer percentage personen dat niet geheel verzekerd is voor kosten van ziekenhuisopnamen (4\%).

Ten aanzien van de afstand tot het dichtstbijzijnde ziekenhuis kunnen er geen significante verschillen tussen de diverse populaties worden vastgesteld. Wat betreft de specialistendichtheid is er geen significant verschil tussen de onderzoekspopulaties van model VIII $A$ en VIII C (ruim 54 per 100.000 inwoners). De tijdbestedingsgroepen 2, 4 en 5 wonen gemiddeld genomen in regio"s met een significant lagere specialistendichtheid. Voor de beddendichtheid geldt een vergelijkbaar patroon met dat verschil dat tijdbestedingsgroep 5 nu niet met een lager dan gemiddelde beddendichtheid wordt "geconfronteerd".

Zoals uit tabel 6.2 . blijkt is het aantal warnemingen binnen diverse tijdbestedingsgroepen gering waardoor de betrouwbaarheid van de gegevens afneemt en daarmee ook de toetsingskracht van de te schatten modellen. Daarnaast kan als gevolg van de wijze van registratie in de Gezondheidsenquête de onderzoekspopulatie van model VIII A niet zonder meer als representatief beschouwd worden voor de totale opgenomen ziekenhuispopulatie (zie ook Van Brekel, 1985b). 


\subsection{RESULTATEN}

In deze paragraaf zullen achtereenvolgens de resultaten gepresenteerd worden van de modellen waarin de kans op minstens één ziekenhuisopname de te verkllaren variabele is (model VII) en modellen waarin de gemiddelde verpleegduur als zodanig functioneert (model VIII).

\subsubsection{Opnamekans}

In tabel 6.3. staan de schattingsresultaten van model VII weergegeven. Hieruit blijkt dat voor model VII A de verwachting bevestigd wordt dat de vijf tijdbestedingsgroepen qua teken een grotere kans op een ziekenhuisopname hebben dan de referentiegroep. De gevonden samenhangen zijn significant bij $\mathrm{p} \leq 0,10$ met uitzondering van de coëfficiënt voor de groep scholieren en studenten. In de C-variant van model VII blijkt de tijdprijs voor een ziekenhuisdag tevens het verwachte negatieve effect op de opnamekans te hebben $(\mathrm{p} \leq 0,05)$.

Ten aanzien van de variabele afstand zijn hiervoor geen eenduidige verwachtingen uitgesproken in verband met het deels kruistijdprijs- en deels eigen tijdprijskarakter van deze variabele. Het feit dat deze variabele in de A-variant niet significant is en in de C-variant significant is met een positief teken, zou er op kunnen wijzen dat in de $\mathrm{C}$-variant het kruistijdprijseffect domineert. Dat wil zeggen dat bij een toename van de afstand het substituut poliklinische hulp minder voorkeur heeft voor deze onderzoekspopulatie.

Geen van de overige economische variabelen blijkt in beide varianten een significant effect op de opname-kans te hebben. Het niet (geheel) verzekerd zijn voor ziekenhuisopnamen heeft in beide modellen geen invloed op de kans op opname. Van Vliet $(1988$, p. 104 e.v.) vond wel een positief effect van huisarisdichtheid op de opnamekans van particulier verzekerden. Zijn interpretatie van dit fenomeen, namelijk dat een hogere huisartsdichtheid tot meer verwijzingen en tot meer kans op hospitalisatie leidt, wordt overigens niet door de bevindingen in hoofdstuk 5 bevestigd. Mogelijk is dit een voorbeeld van een "aanbod-effect" dat veroorzaakt wordt door een niet adequate correctie voor tijdprijzen (zie ook paragraaf 2.4.). Het huishoudinkomen tendeert een negatief effect in model VII $C$ te hebben $(p \leq 0,15)$, terwijl de loonvoet in dit laatste model geen effect heeft.

Van de aanbodvariabele specialistendichtheid wordt in geen van beide modellen een significant effect gewonden. Dit komt overeen met de resultaten van de eerder aangehaalde studies van Van Vliet en Van Doorslaer (1987) en Van Vliet (1988). Beddendichtheid heeft in model VII A geen effect, terwijl deze variabele in model VII $\mathrm{C}$ wel ertoe neigt een significant positieve invloed op de opnamekans te hebben ( $\mathrm{p} \leq$ $0,20)$. De achtergrond hiervan zou kunnen zijn, dat deze variabele een uiteenlopend effect heeft op deelpopulaties. Deze veronderstelling wordt bevestigd door de studie van Van Vliet en Van de Ven (1984) die uiteenlopende effecten van beide aanbodvariabelen op de opnamekans voor ziekenfonds- en particulier verzekerden vinden.

Van Vliet (1988) vond bij een vergelijkbare analyse op een populatie van particulier verzekerden eveneens geen effect van het hebben van een eigen risico. Wel vond hij 
Tabel 6.3. Fesultaten logisitische regressife kans op minstens én ziekenhulsopname (t-waarden tussen haakjes)

\begin{tabular}{|c|c|c|}
\hline VerkLarende variabelen & MODEL VII A & MODEL VII C \\
\hline \multicolumn{2}{|l|}{ Tijdorijs verpleegdag (b) } & \multirow[t]{6}{*}{$-0.8360(-2.97)$} \\
\hline (1) Full-time loontrekkers (a) & $0.3181(1.78)$ & \\
\hline (3) woll. in huish. met kind (a) & $0.5880(3.11)$ & \\
\hline (4) Scholieren en studenten (a) & $0.2368(1.11)$ & \\
\hline (5) Niet-actieven (a) & $0.4123(2.15)$ & \\
\hline (6) Res tgroep (a) & $0.4970(2.70)$ & \\
\hline Afstand zlekenhuis (b) & $-0.0570(-0.66)$ & $0.4251(2.42)$ \\
\hline Eigen bijdrage ziekenhuis (a) & $0.0279(0.31)$ & $-0.1044(-0.48)$ \\
\hline Inikomen & & $-0.0693(-1.50)$ \\
\hline Loonvoet & & $0.7849(0.98)$ \\
\hline Speciat is tendich theid & $0.0018(0.57)$ & $0.0037(0.58)$ \\
\hline Beddendich theid & $0.0186(0.44)$ & $0.1443(1.55)$ \\
\hline Leeftijd & $-0.0062(-1.32)$ & $0.0233(2.47)$ \\
\hline Gezondheidstoestand (a) & $0.4248(6.24)$ & $0.4189(3.19)$ \\
\hline Langdurige aandoeningen (b) & $0.8771(6.25)$ & $0.8281(2.90)$ \\
\hline Geslacht (a) & $0.0395(0.52)$ & $-0.1038(-0.67)$ \\
\hline opleiding & $-0.0850(-1.24)$ & $0.1526(1.07)$ \\
\hline Constante & $-1.1279(-1.62)$ & $-1.8135(-1.30)$ \\
\hline$N$ & 5964 & 2073 \\
\hline \multicolumn{3}{|c|}{ Predictieve waiarde van de voorspelling: } \\
\hline wel opgenomen $(c)$ & $16 \%(10 \%)$ & $9 \%(5 \%)$ \\
\hline niet opgenomen (c) & $96 \%(2 \%)$ & $98 \%(3 \%)$ \\
\hline Entropiemaats taf & 0.021 & 0.018 \\
\hline Log likelihood & -1346.7 & -372.3 \\
\hline
\end{tabular}

(a): Betreffende variabele is en dumy-variabele.

(b): Betreffende variabele is logaritmisch getransformeerd.

(c): Tussen haakjes is de winst aan predictieve waarde ten opzichte van de apriori kans opgenomen.

een positief effect van het hebben van $80 \%$ dekking van kosten verbonden met huisartshulp en voorgeschreven medicijnen en het tegelijkertijd hebben van een volledige dekking van alle kosten verbonden met overige medische consumptie. Zijn interpretatie hiervan is dat deze groep meer kans op een huisartsconsult heeft en als gevolg hiervan ook meer kans heeft om verderop in het medische systeem te raken. Het ligt buiten het bestek van deze studie om een dergelijk effect ook voor deze onderzoekspopulatie te toetsen. Meer onderzoek naar deze indirecte verzekeringseffecten is echter op zijn plaats. 
Van de gezondheidsindicatoren hebben de dummy-variabelen voor de eigen gezondheidsperceptie en de variabele met betrekking tot het aantal langdurige aandoeningen positieve effecten in beide modellen. Leeftijd heieft alleen in model VII $C$ een significant effect. Noch geslacht noch opleidingsniveau heeft in een van beide modellen een significant effect.

Tabel 6.4. Gevoellgheld van opnamekans voor een verandering in de tijdprijsindlicatoron (ceteris paribus) ${ }^{\mathrm{a}}$

Model VII A Modiel WII C

(1) Full-time Loontrekkers (0->1)

$+35 \%$

(3) Volledig in huishouden met kind $(0->1)$

$+70 \%$

(4) Schotiteren en studenten (0->1)

(5) Niet-actieven $(0->1)$

$+45 \%$

(6) Restgroep $(D->\|)$

$+57 \%$

Tijoprijselasticiteit
$-0.79$

a)

Effecten zijn weergegeven indien de geschat te coëfficiënten significant van mul verschillen bij $p \leq 0.10$.

In tabell 6.4. wordt een overzicht opgegeven wan de omvang van de waargenomen tijdprijseffecten op de opnamekans. Deze is voor de dummy-variabelen uit de A-variant berekend op basis van een verandering van deze variabele van 0 naar 1 voor de betreffende deelpopulatie. Voor de C-variant is op de gebruikelijke wijze de elasticiteit van de opname-kans ten aanzien van de tijdprijs van een verpleegdag berekend. Uit het overzicht blijkt dat een werandering van de referentiegroep naar één van de overige tijdbestedingsgroepen tot een aanmerkelijke toename van de kans op minstens eén ziekenhuisopname leidt variërend van $35 \%$ tot $70 \%$. Deze kanstoename is het grootste (70\%) voor personen behorende bij groep 3. De restgroep heeft $57 \%$ meer kans op een ziekenhuisopname en personen behorende tot de niet-actieven $45 \%$. De groep loontrekkers hebben ceteris paribus $35 \%$ meer kans op een ziekenhuisopname. De groep scholieren en studenten tendeert een hogere kans op een ziekenhuisopname te hebben $(22 \%)$. Dit kanswerschil is echter niet significant.

Voor de groep waarwoor een individuele tijdprijs bekend is, bedraagt de elasticiteit van de opnamekans ten opzichte van een verandering in de tijdprijs van een verpleegdag 0,79. Tot zover de bespreking van de modelvarianten voor de opnamekans.

\subsubsection{Ligduur}

In tabel 6.5. is het overzicht weergegeven van de schattingsresultaten van de varianten van model VIII. Deze modellen zijn geschat op die deelpopulaties, waartoe individuen behoren die minstens eén ziekenhuisopname hebben gerapporteerd over een periode van eén jaar voorafgaand aan de enquête. 
In de A-variant van het model hebben de vijf dummy-variabelen voor de tijdsbesteding wel weer een positief teken, echter geen wan de vijf heeft nu nog een significante betekenis voor de verpleegduur. De dummy-variabele van tijdbestedingsgroep 5 komt met een $p$-waarde wan 0,15 het dichtst in de buurt van de kwalificatie "significant". De tijdbestedingsgroep 4 lijkt zich wederom het minst te onderscheiden van de referentiegroep. In de C-variant van het modell wordt eveneens geen significant effect van de tijdprijs op de verpleeguur wonden.

De variabele afstand heeft een significant negaticf effect in model VIII A. Dit bevestigt de in paragraaf 6.2. genoemde veronderstelling dat met name bij de ligduur afstand als een element van eigen tijdprijs beschouwd kan worden. De elasticiteit van de

Tabel 6.5. Pesultaten regressle-analyse verpleegduur door mlddel van de gewone klelnste kwadraten methode

( $t$-waarden tussen haakjes)

MODEL VIII C

Tijdprijs verpleegdag (b)
0.0312
$(0.13)$

(1) Full-time loontrekkers la

$0.2807 \quad(0.91)$

(3) Voll. in huish. met kind (a)

0.3414

$(1.06)$

(4) Scholieren en studenten (a)

$0.1163(0.31)$

(5) Niet-aktieven (a)

$0.4676(1.45)$

(6) Restgroep (a)

0.2710

$(0.86)$

Afsitand ziekenhuis (b)

$-0.1398$

$(-1.93)$

$-0.0749 \quad(-0.50)$

Niet (geh.) verz. ziekenhuis (a) $-0.0325 \quad(-0.21$ )

$-0.2287 \quad(-0.65)$

Inkomen

$0.0262 \quad(0.71)$

Loonvoet

$0.1310 \quad(0.18)$

Specialisten dichtheid

$-0.0034 \quad(-1.32)$

0.0037

$(0.62)$

Bedden dichtheid

$0.0406(1.18)$

0.0391

$(0.50)$

Leeftijd

$0.0043(1.05)$

$-0.0112$

$(-1.47)$

Gezoncheids toes tand (a)

0.2561

( 2.31)

0.4430

(2.15)

Langdurige aandoeningen (b)

0.1303

$(1.14)$

0.1742

$(0.78)$

Geslacht (a)

$-0.1209$

$(-0.86)$

$-0.1269$

$(-0.48)$

opleiding

0.0211

$(0.37)$

$-0.1138$

$(-1.07)$

Kons tante

1.9125

2. 2077

N

396

102

R2

0.0878

0.1587

$\mathrm{F}$

2.62

1.40

(a): Betreffende variabele is een dumy-variabele.

(b): Betreffende variabele is logari tmisch getransformeerd. 
verpleegduur als gevolg van veranderingen in de afstand bedraagt $-0,14$. Het niet geheel werzekerd zijn woor ziekenhuisopname heeft in beide modellen geen effect op de verpleegduur. Deze uitkomst sluit aan bij de bevindingen van Van Vliet (1988, p. 140). Hiij vindt eveneens geen verzekeringseffecten op de verpleegduur bij particulier verzekerden.

De hoogte van het huishoudinkomen evenals die van de loonvoet heeft in model VIII C geen invloed op de verpleegduur. Noch de specialisten- noch de beddendichtheid blijken in beide modellen een significante invloed op de verpleegduur te hebben. Van de gezondheidsindicatoren heeft alleen de beleving van de eigen gezondheidstoestand een significant positief effect op de verpleegduur. Tot slot heeft model VIII $C$ een dermate lage F-waarde dat gesteld moet worden dat de multiple correlaties gezamenlijk niet van nul verschillen. Derhalve heeft de relatief hoge $\mathbb{R}^{2}$ statistisch geen betekenis.

\subsection{SAMENVATTING EN CONCLUSIE}

In dit hoofdstuk is nagegaan of en in welke mate tijdprijzen van invloed zijn op de kans op minstens één ziekenhuisopname en indien opgenomen op de gemiddelde verpleegduur. Daar er over het algemeen onzekerheid bestaat over de totale tijdprijs van een ziekenhuisopname zijn er modellen geschat waarin het effect van het behoren tot een bepaalde tijdbestedingsgroep op zich is nagegaan. Daarnaast is er voor individuen waarvan een individuele tijdprijs voor een verpleegdag berekend kan worden het effect hiervan onderzocht.

Op basis van de gepresenteerde resultaten kan gesteld worden dat de opnamekans voor de diverse tijdbestedingsgroepen significant groter is dan die van de referentiegroep met uitzondering van de opnamekans van tijdbestedingsgroep 4. Deze kanstoename ligt in de orde van grote van $35 \%$ voor full-time loontrekkers, $45 \%$ voor de niet-actieven, $57 \%$ woor de restgroep en $70 \%$ voor de personen die hun tijd volledig in het huishouden besteden. Daarnaast wordt voor de personen, waarvan een tijdprijs voor een verpleegdag berekend kan worden, een significant negatief effect van deze variabele op de opnamekans gevonden. De op basis hiervan berekende elasticiteit bedraagt $-0,79$. Ditt wil zeggen dat indien de tijdprijs met bijvoorbeeld $10 \%$ stijgt de kans op een ziekenhuisopname met zo'n $8 \%$ afneemt.

Ten aanzien van de verpleegduur kan voor de genoemde tijdprijsindicatoren geen significant effect worden vastgesteld. Wel tenderen alle 5 tijdbestedingsgroepen een gemiddeld langere verpleegduur te hebben dan de referentiegroep. In model VII C bleek de afstand tot het ziekenhuis te functioneren als positieve kruisprijs. In model VIII $A$ heeft de afstand een significant negatief effect op de verpleegduur (elasticiteit bedraagt $-0,14$ ). Noch het niet (geheel) verzekerd zijn voor ziekenhuisopname noch het inkomen of de loonvoet blijken significante effecten te hebben in eén van de modellen. Wel tendeert het huishoudinkomen een negatief effect te hebben op de opnamekans.

Van de beide aanbodwariabelen, specialisten- en beddendichtheid wordt over het algemeen in geen van de modellen een significant effect gevonden noch op de opnamekans noch op de verpleegduur. Uitzondering hierop is cen positief effect van de beddendichtheid op de opnamekans van personen met een inkomen uit arbeid (model VII C). Van de gezondheidsindicatoren blijken met name de subjectieve 
beleving van de gezondheid en het aantal langdurige aandoeningen van invloed te zijn op de opnamekans en de verpleegduur.

Vergelijkbare studies ten aanzien van tijdprijseffecten op deze consumptiecategorieenn zijn niet bekend. Acton (1973a) heeft alleen reis- en wachttijden voor poliklinische hulp als kruisprijzen in zijn model voor het aantal verpleegdagen opgenomen. Hij vindt echter geen énduidige effecten voor deze variabelen.

Uit de hier gepresenteerde resultaten kan een bevestiging gevonden worden voor de hypothese dat tijdprijzen van invloed zijn op de kans op opname in een ziekenhuis. Ten aanzien van de verpleegduur wordt deze hypothese niet bevestigd. Toetsing van de modellen voor de laatstgenoemde consumptiecategorie worden echter bemoeilijkt door het gering aantal waarnemingen en de wijze waarop de onderzoekspopulatie gedefinieerd is in de Gezondheidsenquête. Het buiten beschouwing laten van de zogenaamde geinstitutionaliseerde bevolking beperkt de representativiteit van de onderzoekspopulatie die aan de modellen VIII $A$ en $C$ ten grondslag ligt.

Tot slot wijzen diverse studies in de richting dat opnamekans en verpleegduur mede beïnvloed worden door zogenaamde sociale indicaties. Zo blijkt uit onderzoek van Geurts en Janssen (1987) dat ongehuwden, weduwen en weduwnaren een lagere opnamekans hebben. Daarnaast blijken deze groepen en gescheiden personen een hoger gemiddelde verpleegduur te hebben dan gehuwden. De uitkomsten in de studie van Van Vliet (1988) komen hiermee overeen. Deze indicatoren voor sociale omgeving zijn in de hier gepresenteerde modellen niet opgenomen. Verder onderzoek naar mogelijke samenhang met de tijdbestedingsvariabelen en tijdprijsvariabelen is op zijn plaats. 


\section{HET EFFECT VAN TIJDPRIJZEN OP DE VRAAG NAAR GEZONDHEID}

"If there was an agreed world plan to seek to maximise the average length of life of all mankind, this would clearly involve a transfer of resources from rich to poor countries." (Sharp, 1981).

\subsection{INLEIDING}

In de vier voorgaande hoofdstukken zijn empirische modellen geschat, waarbij medische voorzieningen beschouwd werden als goederen die op zichzelf nut hebben voor de gebruiker. In de analyse was tijd een element van de totale prijs van het betreffende consumptiegoed. Zoals in hoofdstuk 1 reeds is uiteengezet kan gezondheid in navolging van Grossman (1972b) opgevat worden als kapitaalvoorraad c.q. een investeringsgoed. In de afweging die een individu makt ten aanzien van de omvang van deze voorraad speelt tijd zowel een rol in de kostensfeer als in de sfeer wan de opbrengsten. Hierbij wordt de hoeveelheid tijd, die beschikbaar is voor allerlei gewenste activiteiten, beschouwd als een opbrengst van gezondheid. De beschikbare hoeveelheid tijd komt tot viltdrukking in bijvoorbeeld het aantal dagen dat een persoon niet belemmerd is in zijn activiteiten als gevolg van ziekte.

In dit hoofdstuk zullen op basis van deze benadering vraagfuncties van gezondheid respectievelijk gezonde dagen geschat worden. In paragraaf 7.2. wordt ingegaan op de gedragsvoorspellingen zoals die uit het investeringsmodel afgeleid kunnen worden. Na een beschrijving van de empirische modelspecificatie in dezelfde paragraaf worden in paragraaf 7.3. de resultaten van de modelschattingen gepresenteerd en besproken. In de slotparagraaf 7.4. wordt een samenvatting gegeven. Van de in dit hoofdstuk gehanteerde symbolen is in bijlage 3 een overzicht opgenomen. 


\subsection{THEORIE, VERWACHTINGEN EN MODELSPECIFICATIE}

In hoofdstuk 1 is reeds ingegaan op de aannamen en de basisstructuur van het model waarin gezondheid als een kapitalgoed wordt opgevat. Hierna wordt wat specifieker op dit model ingegaan om op formele wijze af te leiden welke effecten er verwacht kunnen worden van een toename van de kosten van de tijdinputs op de uiteindelijk gevraagde hoeveelheid gezonde tijd. Hierbij wordt gezonde tijd opgevat als het aantal dagen in een periode dat men niet in zijn activiteiten belemmerd is door ziekte. De produktiefunctie van gezonde tijd $\left(\mathrm{h}_{\mathrm{i}}\right)$ wordt door Grossman (1972b) als volgt gespecificeerd:

$\mathrm{h}_{\mathrm{i}}=365-\mathrm{BH}_{\mathrm{i}}^{\mathrm{C}}$

Hierin staat $h_{i}$ voor het aantal gezonde dagen in periode $i$ en $H_{i}$ voor de gezondheidswoorraad in de betreffende periode. $\mathrm{B}$ en $\mathrm{C}$ zijn positieve constanten die het specifieke verloop van deze produktiefunctie weergeven. In figuur 7.1. is dit grafisch weergegeven.

Figuur 7.1. Relatie tussen gezondheidsvoorraad en aantal gezonde dagen

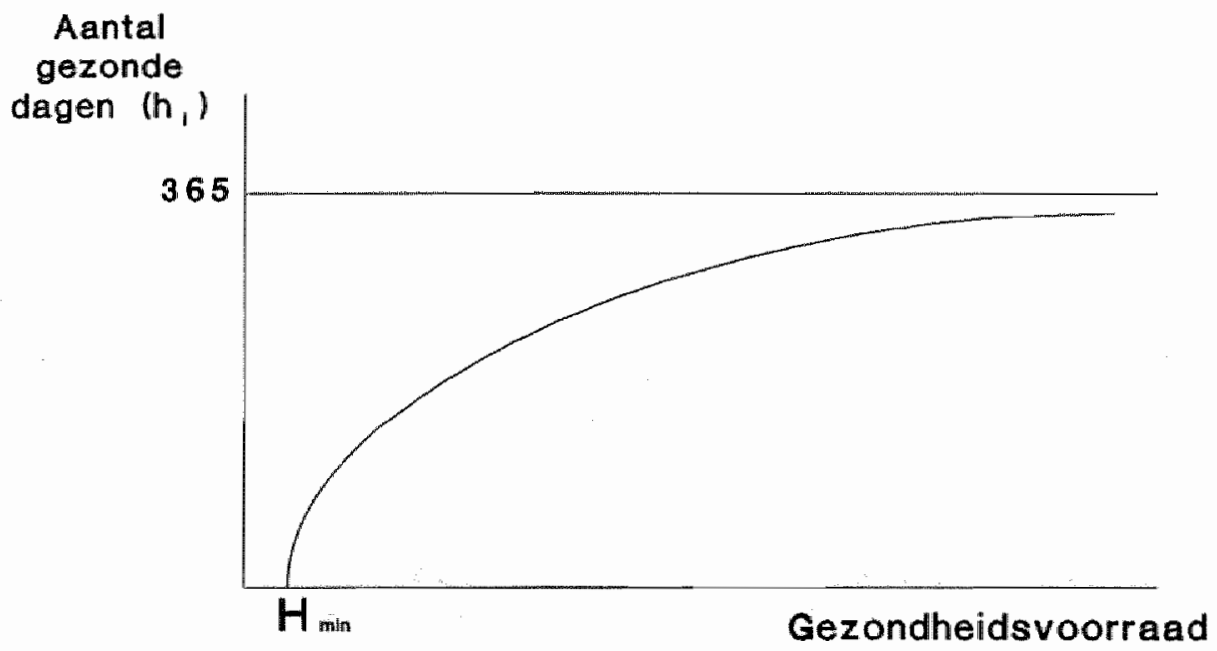


Het verloop van deze produktiefunctie is gebaseerd op de aanname van een afnemend grensprodukt van de gezondheidsvoorraad. Dit lijkt aannemelijk omdat het maximaal aantal te produceren gezonde dagen nu eenmaal in een bepaalde periode (bijvoorbeeld 1 jaar) begrensd is. Op basis van produktiefunctie (1) en de optimumconditie voor het zuivere investeringsmodel (zie bijlage 2):

$$
\gamma_{i}=\frac{W_{i} G_{i}}{\mathbb{M}_{i-1}}=r+\delta_{i}
$$

is de vergelijking voor de marginale efficiëntie curve (ME-curve) af te leiden ${ }^{1}$

$$
\ln \gamma_{i}=\ln B C-(C+1) \ln H_{i}+\ln W-\ln \pi_{i}
$$

Hierin is $\Pi_{i}$ gelijk aan de marginale kosten van een gezondheidsinvestering. In verband met toepassing van het model ten behoeve van de verklaring van variatie in gezondheid tussen personen in een bepaalde periode in plaats van een intertemporele toepassing kan $\Pi_{i-1}$ gelijk gesteld worden aan $\Pi_{i}$. Vergelijking (3) maakt duidelijk dat de marginale efficiëntie oftewel de opbrengstvoet van de laatste investering in gezondheid afhankelijk is van de actuele gezondheidsvoorraad in periode $i\left(H_{i}\right)$, de loonvoet (W) en de marginale kosten van deze laatste investering $\left(\pi_{i}\right)$.

De elasticiteit van de ME-curve bedraagt nu:

$\varepsilon=-\frac{\delta \ln \mathrm{H}_{\mathrm{i}}}{\delta \ln \gamma_{i}}=\frac{1}{1+\mathrm{C}}<1$ omdat $\mathrm{C}>0$ is.

In figuur 1.1. in paragraaf 1.4 . is het verloop van de relatie tussen de marginale efficiëntie $\gamma_{i}$ en de gezondheidswoorraad $\mathrm{H}_{\mathrm{i}}$ weergegeven.

Oplossing van vergelijking (3) voor $\ln H_{i}$ en substitutie van $\gamma_{i}$

door $\mathrm{r}+\delta_{i}$ geeft de volgende vraagfunctie voor de gezondheidsvoorraad:

$\ln H_{i}=B^{p}+\varepsilon \ln W_{i}-\varepsilon \ln \Pi_{i}-\varepsilon \ln \left(r+\delta_{i}\right)$

Hierin is $B^{\prime}=\ln B C /(1+C)$.

Indien verondersteld wordt dat de intrestvoet $\mathrm{r}$ nul is kan (4) herschreven worden als:

$\ln H_{i}=B^{\prime}+\varepsilon \ln W_{i}-\varepsilon \ln \Pi_{i}-\varepsilon \ln \delta_{i}$ 
Vervolgens wordt aangenomen dat de depreciatievoet toeneemt met leeftijd oftewel,

$\ln \bar{\delta}_{1}=\ln \bar{\delta}_{0}+\bar{\delta}_{1}$

Substitutie van vergelijking (5) in $\left(4^{\prime}\right)$ leidt tot (4"), waarbij alle variabelen opgevat werden als afwijkingen van een gemiddelde, waardoor de constante termen kunnen vervallen. De vraagfunctie naar gezondheid is nu te schrijven als:

$\ln H_{i}=\varepsilon \ln W_{1}-\varepsilon \ln \pi_{1}-\varepsilon \bar{\delta}_{i}-\varepsilon \ln \delta_{0}$

Aannemende dat de huishoudproduktiefunctie voor investeringen in gezondheid een Cobb-Douglas karakter heeft (zie bijlage 2) kan deze geformuleerd worden als:

$\ln I_{i}=r_{H} E+a_{1} \ln M_{i}+\left(1-\alpha_{1}\right) \ln T H_{i}$

In deze functie geeft $\alpha_{i}$ het aandeel van medische voorzieningen in de totale kosten van investeringen in de gezondheidswoorraad weer, oftewel is de elasticiteit van investeringen $I_{i}$ ten aanzien van medische consumptie $\mathrm{M}_{\mathrm{i}}$. Op analoge wijze is $1-\alpha_{\mathrm{i}}(=\mathrm{K})$ de elasticiteit ten aanzien van tijdinputs $\left(\mathrm{TH}_{\mathrm{j}}\right)$. Vervolgens is aangenomen dat het niveau van de opleiding $(E)$ de efficièntie van deze produktiefunctie positief beïnvloedt $\left(r_{H}>0\right)$. Uit de specificatie van deze produktiefunctie volgt dat de substitutie-elasticiteit $\left(\sigma_{\mathrm{p}}\right)$ tussen de beide inputs tijd en medische voorzieningen gelijk is aan eén ${ }^{2}$. Tevens volgt hieruit dat $K$ evenals $\alpha_{1}$ constanten zijn en derhalve onafhankelijk zijn van de prijzen van deze inputs.

De kosten van een investering in gezondheid worden gedefinieerd als:

$\mathrm{C}_{\mathrm{i}}=\Pi_{\mathrm{i}} \mathrm{I}_{\mathrm{i}}=\mathrm{PM}_{\mathrm{i}}+\mathrm{W}_{\mathrm{i}} \mathrm{TH}_{\mathrm{i}}$

In het punt waar de kosten minimaal zijn geldt dat de substitutievoet van de inputs gelijk is aan hun prijsverhouding, oftewel

$\frac{\mathrm{P}}{\mathrm{W}_{\mathrm{i}}}=\frac{\alpha_{1}}{1-\alpha_{1}} \frac{\mathrm{TH}_{\mathrm{i}}}{\mathrm{M}_{\mathrm{i}}}$

Combinatie van de vergelijkingen (8), (7) en (6) leidt tot de marginale kostenfunctie:

$\ln \Pi_{i}=K \ln W_{1}+(1-K) \ln P-r_{H} E$

Substitutie van deze marginale kostenfunctie in de vraagfunctie (4") geeft de herleide vorm van de vraagfunctie voor gezondheid:

$\ln H_{i}=(1-K) \varepsilon \ln W_{i}-(1-K) \varepsilon \ln P+r_{H} \varepsilon E-\varepsilon \bar{\delta}_{i}-\varepsilon \ln \delta_{o}$ 
$\ln H_{i}=B_{w} \ln W-B_{p} \ln P+B_{g} E+B_{i} i+V_{i}$

Hierin is $B_{w}=(1-k) \varepsilon$ enz, en $V_{1}=-\varepsilon \ln \delta_{0}$

Op basis van het voorgaande, waarin is aangenomen dat $0<\mathrm{K}<1$ zal $\mathrm{B}_{\mathrm{w}}>0, \mathrm{~B}_{\mathrm{p}}$ $>0, B_{e}<0$ en $B_{i}<0$ zijn. De term $V_{i}$ is een storingsterm die onder andere opgenomen is omdat de depreciatievoet zal variëren tussen personen van dezelfde leeftijd. Deze variaties kunnen empirisch niet waargenomen worden. Op basis van vergelijking (10) kan direct de elasticiteit van de gezondheidswoorraad ten opzichte van de loonvoet gevonden worden $\varepsilon_{\mathrm{H}, \mathrm{W}}=(1-\mathrm{K}) \varepsilon$

Hieruit blijkt dat het effect van een verandering in de loonvoet op de gezondheidsvoorraad positief is, aannemende dat $K<1$, en toeneemt naarmate de fractie van tijdkosten $(K)$ in de totale kosten van een investering in gezondheid afneemt. Hierbij wordt tevens aangenomen dat de elasticiteit van de MEC-curve $\varepsilon$ positief is.

Vervolgens blijkt uit vergelijking (10) dat het effect van een verandering in de geldprijs van medische voorzieningen onder dezelfde aannamen precies omgekeerd is aan dat van een verandering in de loonvoet. Deze tegengestelde werking in de gereduceerde vorm van de vraagfunctie treedt op ondanks het feit dat beide factoren de marginale kosten doen stijgen (zie vergelijking 9). Reden hiervoor is dat de verandering in de loonvoet het marginaal produkt van gezondheidskapitaal positief beînvloedt en de geldprijs van medische voorzieningen hier geen invloed op heeft. Overigens neemt Grossman (1972b, p. 41) in zijn empirisch model aan dat de prijs van medische voorzieningen $P_{i}$ niet varieert tussen de observatie-eenheden en neemt deze variabele verder niet op. Deze aanname is bij een dwarsdoorsnede-analyse op basis van individuele gegevens voor Nederland niet houdbaar. Het al of niet (geheel) verzekerd zijn voor medische voorzieningen zal bij de empirische operationalisatie van het model in deze studie opgevat worden als een benadering voor $P_{i}$ en middels een dummyvariabele in het model worden opgenomen. Tot slot wordt, aannemende dat $r_{H}$ positief is, een positief effect van het opleidingsniveau op de gezondheidsvoorraad voorspeld. Van de depreciatievoet, die benaderd wordt door leefijd, wordt een negatief effect voorspeld.

In het voorgaande is steeds uitgegaan van het strikte investeringsmodel van Grossman. In het zuivere consumptiemodel wordt aangenomen dat gezondheid een goed is met alleen een direct consumptief nut "het zich beter voelen", en geen indirecte monetaire opbrengsten. In dit geval is het effect van een stijging van de loonvoet slechts dan positief indien gezondheid minder tijdsintensief geproduceerd kan worden dan een gemiddeld ander goed $(\overline{\mathrm{K}}<\mathrm{K})$. Indien aan dit laatste niet voldaan wordt zal de elasticiteit in het consumptiemodel negatief zijn. Vervolgens leiden de hiervoor onderscheiden modelvarianten ook tot andere voorspellingen met betrekking tot vermogensbezit. In het consumptiemodel wordt van vermogen een positief effect op gezondheid verwacht, aannemend dat dit een normaal goed is. In het investeringsmodel wordt er geen effect van vermogen verwacht, aannemend dat rentevoet $r$ onafhankelijk is van de omvang van het vermogen. 
In dit onderzoek is het investeringsmodel gekozen vanwege zijn bijzondere eigenschap dat het tijd als een expliciete opbrengst van gezondheid opvat. Om echter eveneens het onderscheidend effect van vermogen in beide modellen te toetsen zal het huishoudinkomen als een benadering voor vermogen $\left(B_{r} \ln R\right)$ in de te schatten functie (10') worden opgenomen.

Tot slot is er met behulp van vergelijking (1) een variant van (10') te specificeren waarin deze niet cen vraagfunctie voor de voorraad gezondheid uitdrukt maar voor de opbrengst van deze voorraadgrootheid, namelijk gezonde dagen $\left(h_{i}\right)$. Deze laatste stroomgrootheid kan als het negatief van haar complement worden uitgedrukt. Indien dit complement gedefinieerd wordt als dagen met belemmering in activiteiten door ziekte $\left(\mathrm{DBA}_{i}\right)$, kan de samenhang tussen beide grootheden als volgt weergegeven worden,

$h_{\mathrm{i}}=365-\mathrm{DBA}_{\mathrm{i}}$

nu is vergelijking (1) te schrijven als:

$-\operatorname{lnDBA} A_{i}=-\ln B+C \ln H_{i}$

en vergelijking (1.0) als

$-\ln \mathrm{DBA}_{\mathrm{i}}=\mathrm{CB}_{w} \ln \mathrm{W}-\mathrm{CB}_{\mathrm{p}} \ln \mathrm{P}+\mathrm{CB}_{\mathrm{E}} \mathrm{E}+\mathrm{CB}_{\mathrm{i}} \mathrm{i}+\mathrm{CV}_{\mathrm{i}}$

Afhankelijk van het gegeven of de waarde van $C$ éen is of $<1$ zullen de caëfficiënten in deze vraagcurve gelijk aan of kleiner dan die in de vraagfunctie voor de voorraadgrootheid gezondheid zijn. De richting van de verwachte effecten van de variabelen in vergelijking (10") blijft gelijk aan die van vergelijking (10).

Tabel 7.1. Overzicht van verwachte samenhangen tussen de vraag naar gezondheld en een aantal onafhankelijke varlabelen op basis van het investerlngs- respectlevell]k het consumptlemodel van Grossman

\begin{tabular}{lccccc}
\hline & Loonvet & vermogen & geldprijs & leeftijd & opleiding \\
\hline investeringsmode! & + & 0 & - & - & + \\
consumpti emodel & $\pm^{\mathrm{a}}$ & + & - & - & + \\
\hline
\end{tabular}

a)

Afhankelljk van de relatieve tijdsintens teit van de productie van gezondheid.

Op basis van het voorgaande zullen er een tweetal vraagfuncties geschat worden, éen voor de gezondheidsvoorraad en én voor de stroomgrootheid -DBA. De verwachting is dat op basis van het investeringsmodel de loonvoet en het opleidingsniveau een positief effect en de geldprijs en leeftijd een negatief effect op de vraag naar gezondheid zullen hebben. Ter vergelijking zijn in tabel 7.1. tevens de verwachte samenhangen op basis van het consumptiemodel weergegeven. Het effect van de loonvoet is niet eenduidig, terwijl van het vermogen een positief effect verwacht wordt. Van de overige variabelen wordt in beide modellen hetzelfde effect verwacht. 
De schatting van de vraagfunctie naar de voorraadgrootheid gezondheid (model IX) zal op een tweetal populaties plaatsvinden. De eerste populatie omvat de totale populatie van $16 \mathrm{t} / \mathrm{m}$ 64 jaar. Als indicatie voor de tijdswaardering is niet de loonvoet, maar zijn dummy-variabelen voor de in hoofdstuk 2 onderscheidlen tijdbestedingsgroepen in het model IX A opgenomen. De tweede populatie waarvoor deze vraagfunctie (model IX C) geschat wordt heeft betrekking op die deelpopulatie, waarvan de loonvoet wel bekend is en die een inkomen uit arbeid heeft.

De voorraadgrootheid gezondheid is geoperationaliseerd middels de beleving van zijn/haar gezondheid. Deze variabele, die oorspronkelijk een viertal waarden aanneemt, is gedichotomiseerd tot een dummy-variabele. De waarde nul impliceert een beoordeling "slecht", "wisselend", of "gaat wel", de waarde é̂n komt overeen met een beoordeling van de eigen gezondheid als "goed".

De vraagfunctie naar de stroomgrootheid gezondheid (model $\mathrm{X}$ ) wordt eveneens voor de hierboven onderscheiden beide onderzoekspopulaties geschat. Operationalisering van de stroomgrootheid gebeurt op 2 manieren. Op de eerste plaats wordt in model X A en X C de kans op geen dagen met belemmerde activiteiten (DBA) geschat. Vervolgens wordt voor de deelpopulaties die minstens én dag met belemmerde activiteiten rapporteerden een vraagfunctie geschat waarin het negatief van het aantal dagen met bellemmerde activiteiten (DBA) gedurende een periode van 14 dagen de afhankelijke variabele is.

Naast de variabelen leeftijd, opleiding, niet (geheel) verzekerd voor medische kosten, de dummy-variabelen voor tijdsbesteding in de type A modellen en huishoudinkomen en de loonvoet in de type $C$ modellen zijn er nog een tweetal verklarende variabelen in de modellen opgenomen, te weten "grootte huishouden" en "geslacht".

De eerste is opgenomen om de variabele "huishoudinkomen" te corrigeren voor de omvang van het huishouden. Daarnaast verwacht Grossman (1972b, p. 52) een positief effect van deze variabele op basis van de veronderstelling dat tijd beschikbaar voor het opvoeden van kinderen positief zal samenhangen met de voorraad gezondheidskapitaal van de ouders.

De variabele geslacht is opgenomen om te corrigeren voor structurele verschillen in de gezondheidstoestand die samenhangen met geslacht. Ondanks de langere levensverwachting voor vrouwen worden in empirische studies over het algemeen negatieve samenhangen gevonden (Grossman, 1972b, v.d. Zee, 1982, Verbrugge, 1985, v.d. Brekel, 1987 en Van Doorslaer, 1987).

In paragraaf 3.2. (tabel 3.2.) bleek reeds dat de tijdbestedingsgroepen 1, 2 en 4 een enigszins hoger dan gemiddelde beleving van de gezondheid rapporteerden, terwijl groep 5 aanmerkelijk en groep 6 enigszins lager dan gemiddeld op deze variabele scoorden. Voor wat betreft de kans op dagen met belemmerde activiteiten gedurende een periode van 14 dagen werd er een globaal vergelijkbare situatie gevonden. 


\subsection{RFSULTATEN}

In deze paragraaf worden eerst de schattingsresultaten besproken waarin de beleving van de eigen gezondheid als een benadering voor de gezondheid als voorraadgrootheid wordt gehantererd (modellen IX A en IX C). Daarna worden de resultaten gepresenteerd waarin gezondheid als stroomgrootheid benaderd wordt door de kans op geen dagen met belemmerde activiteiten (DBA's) respectievelijk, voorwaar minstens én DBA, het negatief van het aantal DBA's.

\subsubsection{Gezondheld als voorraadgrootheid}

In tabel 7.2. staan de resultaten weergegeven van de modellen $\mathrm{XX}$ A en $\mathrm{C}$. Hieruit blijkt dat in model $\mathrm{XX}$ A de dummy-variabelen voor de diverse tijdbestedingsgroepen alle een

Tabel 7.2. Fesultaten loglatische regressie-analyse ter verklarling van de vraag naar gezonilheild als voorraadgrootheid

(t-waarden tussen haak) es:)

\begin{tabular}{|c|c|c|c|}
\hline Verklarende variabelen & MODEL IX A & MODEL IV & $\times c$ \\
\hline \multicolumn{2}{|l|}{ Hui shoud-inkomen } & 0.0371 & $(1.36)$ \\
\hline \multicolumn{2}{|l|}{ Loonvoet } & \multirow{6}{*}{\multicolumn{2}{|c|}{-0.9383}} \\
\hline (1) Full-time loontrekkers (a) & $-0.1708(-1.97)$ & & \\
\hline (3) voll. in huish. met kind (a) & $-0.1728(-1.74)$ & & \\
\hline (4) Seholteren en studenten (a) & $-0.1085(-0.82)$ & & \\
\hline (5) Niet-actieven (a) & $-0.7862(-8.09)$ & & \\
\hline (6) Restgroep (a) & $-0.1498(-1.60)$ & & \\
\hline Niet (geheel) verzekerd (a) & $0.4523(3.23)$ & 0.2227 & (2.33) \\
\hline Geslacht (a) & $-0.0788(-1.47)$ & -0.0829 & $(-1.16)$ \\
\hline Leeftijd & $-0.0426(-13.77)$ & -0.0325 & $(-5.65)$ \\
\hline Hui shoudgrootte (b) & $0.2308(2.64)$ & 0.3451 & $(2.50)$ \\
\hline Doleiding & $0.2454(5.25)$ & 0.1787 & $(1.99)$ \\
\hline Constante & $1.3999(3.87)$ & 2.2427 & $(5.36)$ \\
\hline N & 5854 & 2048 & \\
\hline \multicolumn{4}{|c|}{ Predict leve waarde van de voorspelling: } \\
\hline goede gezondheid (c) & $89 \%(8 \%)$ & \multicolumn{2}{|c|}{$89 \%(4 \%)$} \\
\hline anders dan gaede gezondheid (c) & $34 \%(15 \%)$ & \multicolumn{2}{|c|}{$25 \%(10 \%)$} \\
\hline Entroplemaats taf & 0.054 & \multicolumn{2}{|c|}{0.019} \\
\hline Log likel thoad & -2545.1 & \multicolumn{2}{|l|}{-828.6} \\
\hline
\end{tabular}

(a): Betreffende variabele is een dumy variabele.

(b): Betreffende variabele is logaritmisch getransformeerd.

(c): Tussen haakjes is de winst aan predictieve waarde ten opzichte van de apriori kans opgenomen. 
negatief teken hebben. Dit wil zeggen dat personen behorende bij een andere dan de referentiegroep tenderen een kleinere kans te hebben op een beoordeling van de eigen gezondheid als "goed". Alleen voor de groep scholieren en studenten is deze negatieve coëfficiènt niet significant. Voor de groepen 1 en 5 is de coëfficiënt significant bij p < 0,05 en voor de overige twee groepen is deze significant bij $\mathrm{p}<0,10$. Uit de resultaten van model $\mathrm{XX} \mathrm{C}$ blijkt dat de gehanteerde benadering voor de tijdprijs, de loonvoet een onverwacht negatief en significant $(p<0,05)$ effect heeft op gezondheid. Het huishoudinkomen vertoont een positieve niet significante samenhang met gezondheid. De resultaten van model $\mathrm{LX} \mathrm{C}$ wijzen in de richting van de voorspellingen die op basis van het consumptiemodel werden afgeleid.

De benadering voor de aanwezigheid van een geldprijs, de dummy-variabele "niet (geheel) verzekerd" vertoont eveneens tegen de verwachtingen in een positief en in beide modellen een significant teken. Dit wijst in de richting dat deze variabele in sterke mate beïnvloed is door het zogenaamde zelfselectie-mechanisme (Van Vliet en Van de Ven, 1983). Dit impliceert dat deze variabele partieel endogeen is en tevens twee tegengestelde effecten in zich herbergt. Het zelfselectie-effect leidt ertoe dat diegenen met een eigen risico gemiddeld een betere gezondheid hebben. Voor zover deze variabele deze factor meet zal haar coëfficiènt het positieve verband met de afhankelijke variabele weergeven. Opname van deze variabele in het model beoogt echter het voorspelde negatieve prijseffect te toetsen. Indien dit in werkelijkheid bestaat wordt dit effect in het schattingsmodel gedempt door het hiervoor genoemde zelfselectie-effect. Als gevolg hiervan worden de overige coëfficiënten eveneens vertekend ${ }^{3}$.

De dummy-variabele voor geslacht vertoont in beide modellen een negatieve niet significante samenhang. Dit in tegenstelling tot de benadering voor de depreciatievoet, de variabele leeftijd, die het verwacht negatieve effect heeft $(p<0,01)$. De variabele "huishoudgrootte" vertoont in beide modellen een significante positieve samenhang, hetgeen erop wijst dat leden van grote gezinnen over het algemeen een relatief betere gezondheid hebben. Dit lijkt aannemelijk daar het stichten van een huishouden en het krijgen van kinderen over het algemeen mede beïnvloed zal worden door de individuele gezondheidstoestand. Tot slot wordt het verwachte positieve effect van de variabele opleiding eveneens in beide modellen statistisch bevestigd.

In tabel 7.3. worden de effecten van veranderingen in de tijdwaarderingsindicatoren op de beoordeling van de eigen gezondheid weergegeven. Hieruit blijkt dat voor de tijdbestedingsgroepen 1, 3 en 6 de kans op een als goed beoordeelde gezondheid met een vergelijkbaar percentage (3\%) afneemt ten opzichte van de referentiegroep. Voor de tijdbestedingsgroep 5 ligt deze kansvermindering met $18 \%$ aanmerkelijk hoger. Voor de groep scholieren en studenten wordt geen significant verschil ten opzichte van de referentiegroep vastgesteld. De elasticiteit van de kans op een als "goed" beoordeelde gezondheid ten opzichte van de loonvoet bedraggt $-0,04$. Dit betekent dat bij een toename van de loonvoet met bijvoorbeeld $10 \%$ de kans op een goede gezondheid met $0,4 \%$ afneemt.

Zoals hiervoor reeds gesteld sporen deze resultaten niet volledig met de voorspellingen op basis van het investeringsmodel. De uitkomsten van model IX A lijken de verwachtingen van een positieve relatie tussen gezondheid en tijdswaardering te beves- 
Tabel 7.3. Gevoeligheid van de gezondheid voor een verandering in de tijdwaarderingsíndicatoren ${ }^{*}$

Model IX A Model IX C

(1) Full-time loontrekkers $(0->1) \quad-3 \%$

(3) Volledig in huishouden met kind $(0->1) \quad-3 \%$

(4) Scholieren en studenten $(0 \rightarrow 1)$

(5) Niet actieven $(0->1) \quad-18 \%$

(6) Restgroepen $(0->1) \quad-3 \%$

Tijdprijselasticiteit

$-0,04$

a) Effecten zijn weergegeven indien de geschatte coëfficiënten significant wan nul verschillen bij $\mathrm{p} \leq 0,10$.

tigen. Immers personen behorende tot de tijdbestedingsgroep met de veronderstelde laagste tijdswaardering (groep 5) hebben de geringste kans op een goede gezondheid en personen behorende tot tijdbestedingsgroep 2 met de veronderstelde hoogste tijdswaardering hebben de hoogste kans op een goede gezondheid. De regressieresultaten van model IX $\mathrm{C}$ bevestigen deze verwachtingen echter niet. Integendeel, de loonvoet heeft zelfs een significant negatief effect op gezondheid. Het is wel waarschijnlijk dat de mate van samenhang tussen de loonvoet en gezondheid beïnvloed wordt doordat de variabelen inkomen, opleiding en het niet geheel verzekerd zijn positief gecorreleerd zijn met de loonvoet. Schatting van model $\mathbb{I X} \mathrm{C}$ middels stapsgewijze regressie bevestigt dit. Echter deze samenhang tussen de onafhankelijke variabelen blijkt de richting van het effect van de loonvoet op de gezondheidstoestand niet te beïnvloeden.

\subsubsection{Gezondheid als stroomgrootheid}

De vraagfunctie naar de stroomgrootheid "de kans op geen dagen met belemmerde activiteiten" (DBA) wordt afzonderlijk geschat op de twee hiervoor onderscheiden deelpopulaties. Het gaat hierbij om de kans op geen enkele DBA, waarbij de dummyvariabele de waarde 1 aanneemt (modellen X A en X C). De tweede vraagfunctie wordt geschat voor die subpopulaties van beide deelpopulaties, die minstens eén DBA rapporteren. De afhankelijke variabele wordt hierbij getransformeerd als $-\ln D B A_{i}$ (modellen $\mathrm{X} \mathrm{A}^{\prime}$ en $\mathrm{X} \mathrm{C}^{\prime}$ ). De regressieresultaten van deze modellen staan weergegeven in tabel 7.3. Door transformatie van de afhankelijke variabelen is de verwachte richting van de effecten van de onafhankelijke variabelen hier hetzelfde als bij de eerder in dit hoofdstuk besproken modellen. Uit de regressieresultaten van model X A blijkt dat alle tijdbestedingsgroepen met uitzondering van groep 4 een significante kleinere kans op geen DBA hebben. Met andere woorden, deze groepen hebben minder kans dan de referentiegroep om binnen een periode van 14 dagen, ook 14 gezonde dagen te hebben. Uit de regressieresultaten van model $X A^{\prime}$ blijkt dat voorwaar men minstens één DBA rapporteerde er voor wat betreft het aantal DBA's er geen verschillen zijn tussen de 
diverse tijdbestedingsgroepen en de referentiegroep met uitzondering voor de groep niet-actieven.

Tabel 7.4. Resultaten loglstische regresssle-analyse ter verklering van de vrasg naar gezondheid als otroomgrootheld

( $t$-waarden tussen haakjes)

\begin{tabular}{|c|c|c|c|c|}
\hline Verklarende variabelen & MOOEL $\times A$ & MODEL $\times C$ & MOOEL $\times A^{\prime}$ & MOOEL $\times \mathrm{C}^{\prime}$ \\
\hline Hut ishoud-inkomen & & $-0.0277(-0.92)$ & & $0.0155(0.88)$ \\
\hline Loonvoet & & $0.4441 \quad(0.69)$ & & $-0.3400(-0.91)$ \\
\hline (1) Full-time loontrekkers la & $-0.4086(-3.12)$ & & $0.1335 \quad(0.55)$ & \\
\hline (3) voll. in huish. met kind (a & a) $-0.3224(-2.22)$ & & $0.1528(0.56)$ & \\
\hline (4) Schatieren en studenten (a & a) $0.0853(0.47)$ & & $0.2626(0.78)$ & \\
\hline (5) Niet-aktieven (a) & $-0.4940(-3.39)$ & & $-0.5454(-2.05)$ & \\
\hline (6) Restgroep (a) & $-0.4307(-3.13)$ & & $0.1922(0.75)$ & \\
\hline Wiet (geheel) werzekerd (a) & $0.0488(0.84)$ & $0.1921(1.77)$ & $0.1843(1.75)$ & $0.1965(1.57)$ \\
\hline Geslacht $(a)$ & $-0.0330(-0.53)-$ & $-0.1244(-1.57)$ & $-0.1761(-1.58)$ & $0.0023 \quad(0.02)$ \\
\hline Leeftijal & $-0.0066(-1.76)-$ & $-0.0110(-1.66)$ & $-0.0128(-3.86)-$ & $-0.0065(-1.67)$ \\
\hline Huishoudgroot te (b) & $0.3738(3.54)$ & $0.4125(2.66)$ & $0.1188(1.28)-$ & $-0.9970(-2.07)$ \\
\hline Opleiding & $0.0655(1.14)$ & $0.0701 \quad(0.69)$ & $0.1195(2.40)$ & $0.0732(1.26)$ \\
\hline Constante & $1.0498(2.08)$ & $1.9765(4.23)$ & 3.1979 & -1.9821 \\
\hline N & 5854 & 2048 & 581 & 222 \\
\hline \multicolumn{5}{|c|}{ Predictieve waarde van de voorspelling: } \\
\hline minstens éên DBA $(c)$ & $92 \%(2 \%)$ & $91 \%(2 \%)$ & & \\
\hline geen $D B A\langle C\rangle$ & $14 \%:(4 \%)$ & $16 \%(5 \%)$ & & \\
\hline Entropiemaats taf & 0.008 & 0.006 & & \\
\hline Log likel ihood & -1850.6 & -692.2 & & \\
\hline$R 2$ & & & 0.1374 & 0.0842 \\
\hline F & & & 9.083 & 2.81 \\
\hline
\end{tabular}

(a): Betreffende variabele is een dumy-variabele.

(b): Betreffende variabele is logaritmisch getransformeerd.

(c): Tussen haakjes lis de winst aan predictieve waarde ten opzichte van de apriori kans opgenomen.

Uit de regressieresultaten van de modellen $X \mathrm{C}$ en $\mathrm{X}^{\prime} \mathrm{C}^{\prime}$ blijkt dat de loonvoet als benadering voor de tijdswaardering geen significant effect op de kans op eén DBA of het aantal DBA's heeft. Wel heeft de coëfficiènt van deze variabele in model X $\mathrm{C}$ het verwachte positieve teken. Ook het huishoudinkomen blijkt geen significant effect in de laatstgenoemde modellen te hebben. De dummy-variabele voor het niet (geheel) verzekerd zijn tendeeri ook nu in tegenstelling tot de verwachting positief samen te hangen met de vraag naar gezondheid. De coëfficiënt van deze variabele is significant in model X C en X A' $(0,05<p<0,10)$. 
De dummy-variabele woot geslacht tendeert een negatief effect te genereren, waarbij de coefficiënt alleen in model X C significant wordt. Leeftijd heeft overeenkomstig de verwachtingen in alle modelvarianten een significant negatief effect. De variabele huishoudgrootte theeft met uitzondering van model $X C^{\prime}$ een significant positief effect op de kans op gén DBA hetgeen overeenkomt met de schattingsresultaten van model IX. In variant $C^{\prime \prime}$ van model $X$ heeft deze variabele opeens een significant negatief effect. Dit laatste zou erop kunnen wijzen dat indien men eenmaal ziek is, men in grotere huishoudens ook langer ziek is. De uitkomsten van model $\mathrm{X} \mathrm{C}^{\prime \prime}$ dienen echter met de nodige terughoudendheid geinterpreteerd te worden. Door het relatief geringe aantal waarnemingen kan de samenhang tussen een aantal onafhankelijke variabelen de coëfficiënten en hun tekens als gevolg van multicolliniariteit beïnvloeden. De wilsseling van de tekens van een aantal coëfficiënten ten opzichte van model $\mathrm{X} \mathrm{C}$ zou hïerdoor veroorzaakt kunnen worden. De coëfficiënt van de variabele opleiding heeft in alle varianten het werwachte teken, deze bereikt echter alleen in model $\mathrm{X} \mathrm{A}^{\prime}$ een significant niveau in tegenstelling tot in de varianten van model IX.

Tot slot worden in tabel 7.5. de effecten van een verandering in de tijdwaarderingsindicatoren op de kans op geen DBA weergegeven, zoals die van de resultaten van model $\mathrm{X}$ A kunnen worden afgeleid. Hieruit blijkt dat personen behorende bij de tijdbestedingsgroep $56 \%$ minder kans hebben op geen dagen met belemmerde activiteiten in vergelijking met personen behorende tot de referentiegroep. Voor personen behorende tot de tijdbestedingsgroepen 1, 3 en 6 liggen deze kansen respectievelijk $4 \%, 3 \%$ en $5 \%$ lager.

Tabel 7.5. Effecten op de kans op geen DBA als gevolg van een verandering in de tijdwaarderingsindicatoren op basis van model $X A^{*}$

(1) Full-time loontrekkers $(0 \rightarrow 1)$

(3) Volledig in huishouden met kind $(0->1))$

(4) Scholieren en studenten $(0 \rightarrow>1)$

(5) Niet actieven $(0 \rightarrow>1)$

(6) Restgroepen $(0 \rightarrow>1)$
$-4 \%$

$-3 \%$

$-6 \%$

$-5 \%$

a) Effecten zijn weergegeven indien de geschatte coëfficiënten significant van nul verschillen bij $\mathrm{p} \leq 0,10$.

\subsection{BESPREKING EN SAMENVATTING}

De centrale verklarende variabelen in de gereduceerde vormvergelijking van de vratagfunctie naar gezondheid in het investerings- of kapitaalgoedmodel van Grossman zijn de loonvoet, de geldprijs van medische voorzieningen, opleidingsniveau en leeftijd als benadering voor de depreciatievoet van de gezondheidswoorraad. De loonvoet als benadering woor de tijdswaardering blijkt in geen van de modellen het verwachte 
positieve effect te hebben. In model IX $\mathrm{C}$ werd zelfs een negatief significant effect van de loonvoet op de kans op een goede gezondheid gevonden.

In de modellen IX A en X A werden er wel significante samenhangen gevonden tussen het behoren tot een bepaalde tijdbestedingsgroep en gezondheid. Hierbij bleken de diverse tijdbestedingsgroepen over het algemeen significant minder kans te hebben op een goede gezondheid of geen DBA in vergelijking met de referentiegroep waarvan we hebben aangenomen dat deze een relatief hogere tijdswaardering heeft. Grossman (1972b, p. 71 e.v.) vond voor personen met een inkomen uit arbeid well significante positieve effecten. Een mogelijke verklaring voor dit verschil in uitkomsten is dat Grossman de numerieke waardering voor de perceptie van eigen gezondheidstoestand aanpast voor de gemiddelde uitgaven aan medische voorzieningen van deze vier categorieën. Hierdoor wordt er een relatie tussen de te verklaren variabele en een inputvariabele van de produktiefunctie in de te schatten vraagfunctie aangebracht, die nu juist getoetst dient te worden. Daarnaast is het mogelijk dat in de hier geschatte modellen de verzekeringsvariabele, die Grossman niet in zijn model opneemt als gevolg van het zelfselectie-effect ook deels een loonvoet-effect herbergt. Het weglaten van deze variabele leidt wel tot een reductie van de sterkte van de negatieve samenhang tussen de loonvoet en gezondheid. Deze blijft echter negatief. Anderzijds is het mogelijk dat het door Grossman gevonden effect van de loonwoet eigenlijk de uitdrukking is van een omgekeerde causaliteit. Immers personen met een goede beginvoorraad gezondheid zijn over het algemeen beter in staat om een betere opleiding respectievelijk een hoger inkomen per tijdseenheid te realiseren. Zo vond Luft (1975) in een studie naar het effect van slechte gezondheid op inkomens, dat zowel het aantal gewerkte uren als de loonvoet negatief beïnvloed wordt door slechte gezondheid. In een dwarsdoorsnede-analyse en bij afwezigheid van gegevens over de initiële gezondheid $\mathrm{H}_{\mathrm{o}}$ is dit probleem van omgekeerde causaliteit niet te elimineren. Deze kritiek is deels ook geldig voor de gevonden samenhangen tussen de tijdbestedingsgroepen en gezondheid. Immers een groot deel van de groep niet-actieven (76\%) krijgt een uitkering in het kader van de Wet op de Arbeidsongeschiktheid juist vanwege een slechte gezondheid. Hagen (1985, p. 97) wijst eveneens op dit probleem van de wederkerige causaliteit bij de bespreking van Grossman's model.

Een ander opmerkelijk verschil met de bevindingen van Grossman is dat hij een negatief effect van huishoudinkomen vindt, terwijl deze variabele in deze studie tendeert een positief effect op gezondheid te hebben. Muurinen (1982) windt in een vergelijkbaar model eveneens een positief verband tussen inkomen en gezondheid. Zij beschouwt deze variabele echter als een indicator voor de loonvoet, die zij niet afzonderlijk in haar model opneemt. Overigens beïnvloedt het weglaten van de variabele huishoudinkomen nauwelijks het effect van de loonvoet in de modellen IX A, X A en X A". Auster e.a. (1972) vinden op basis van een dwarsdoorsnede-analyse van gegevens van Amerikaanse staten evenals Grossman een negatief verband tussen inkomen en gezondheid. Zij stellen dat een toename van inkomen tot een bepaald niveau gepaard gaat met een toenemende gezondheid als gevolg van betere woeding, huisvesting, etc. Vanaf een bepaald niveau slaat dit positief verband om in een negatief verband als gevolg van factoren als overdadige voeding, stress en andere belastende factoren. Indien men deze redenering volgt, zou men voor Nederland kunnen stellen dat dit omslagpunt blijkbaar nog niet bereikt is. 
De variabele voor het niet (geheel) verzekerd zijn, als benadering voor de aanwezigheid van een geldprijs geeft in alle geschatte modellen een onverwacht significant positief effect. Zoals al eerder gesteld is wordt dit resultaat mogelijk veroorzaakt door het zelfselectie-effect en het hierboven gesuggereerde "opbrengst-effect" van de loonvoet. Het zijn immers vooral gezonde personen met gemiddeld een hoger inkomen die kiezen voor een of andere vorm van eigen risico. Daarnaast is gezondheidszorg slechts eén van de inputs in de productiefunctie van gezondheid. Een vrijwillig gekozen vorm van eigen bijbetaling kan tevens uildrukking zijn van gewenste substitutie van gezondheidszorg door bijvoorbeeld inputs als gezonde voeding en gezondheidsbevorderende recreatieve activiteiten. Als gevolg van de vergaande vereenvoudiging van de in het model gehanteerde productiefunctie is het mogelijk dat het positieve effect van de verzekeringsvariabele een uitdrukking is van deze substitutie tussen inputs.

Het opleidingsniveau heeft over het algemeen het verwachte positieve effect. In de modellen voor de vraag naar gezondheid als stroomgrootheid wordt het effect van deze variabele echter alleen in model $\mathrm{X} \mathrm{A}^{\prime}$ significant. Grossman vindt echter ook in het model met de loonwoet als benadering voor tijdswaardering (model $\mathrm{X} \mathrm{C}$ en $\mathrm{X} \mathrm{C}$ ) significante resultaten. Dit verschil wordt waarschijnlijk veroorzaakt doordat zijn waarnemingsperiode zich uitstrekt over een heel jaar. Hierdoor ligt in zijn schattingspopulatie het aantal personen met minstens eén DBA aanmerkelijk hoger (32\%) in vergelijking met de schattingspopulatie van dit onderzoek (10\%). Hierdoor neemt de variantie in deze variabele toe en daarmee ook de toetsingskracht van het model. Dit gebrek aan toetsingsvermogen komt hier tot uitdrukking in de lage waarden van de entropiemaatstaf van model X A en X C.

De variabele leeftijd heeft in alle modellen het verwachte negatieve effect. Dit komt overeen met Grossman's bevindingen. Tot slot de twee variabelen waarvan de effecten niet in het investeringsmodel voorspeld werden, geslacht en huishoudgrootte. De eerste tendeert een negatief effect te hebben op de vraag naar gezondheid, behalve op het aantal DBA's voorwaar men minstens één DBA heeft. Dit resultaat komt overeen met de bevindingen van Grossman (1972b) en Muurinen (1982). De variabele huishoudgrootte vertoont een omgekeerde samenhang. Deze is overeenkomstig de verwachting positief in model IX en X, maar wordt negatief in model IX $\mathrm{C}^{\prime}$ Dit laatste resultaat zou te wijten kunnen zijn aan multicollineariteit die de uitkomsten van dit model in haar geheel minder betrouwbaar maakt.

Terugkomend op de centrale vraagstelling van dit hoofdstuk of en in welke mate de tijdswaardering van invloed is op de individuele gezondheidsvoorraad respectievelijk de productie van gezonde tijd kan het volgende gesteld worden. De positieve relatie die op basis van het investeringsmodel van Grossman verwacht werd, lijken door de resultaten van model IX A en X A bevestigd te worden. Het analoge model IX C waarin de loonvoet als indicator voor de tijdswaardering is opgenomen laat echter een tegenovergestelde samenhang zien. Een verklaring, die hiervoor kan worden aangedragen, is dat voor deze deelpopulatie het consumptiegoed karakter van gezondheid domineert en dat gezondheidszorg voor deze deelpopulatie een relatief tijdintensief goed is. Het is echter moeilijk om een plausibele verklaring voor deze veronderstelling aan te dragen. Integendeel de populatie waarop de $\mathrm{C}$-modellen geschat zijn bestaat uitsluitend uit personen met een inkomen uit arbeid. Men mag derhalve veronderstellen dat gezondheid en inkomen op de langere termijn samenhangen. Een andere meer voor de hand liggende verklaring kan op basis van de zogenaamde "joint 
production hypothese" (Grossman 1972b, p. 74) gevonden worden. Hierbij gaat Grossman ervan wit dat er naast medische consumptie $\left(X_{1}\right)$ andere marktgoederen $\left(X_{2}\right)$ inputs in de huishoudproduktiefunctie vormen die een negatief marginaal effect op gezondheid hebben. Bij dit laatste kan men denken aan bijvoorbeeld alcoholconsumptie, roken, ongezonde voeding. Indien de inkomenselasticiteit van $\mathrm{X}_{2}$ goederen groter is dan die van de $X_{1}$ goederen, zal een toename van het inkomen een negatief effect op gezondheid hebben. Het negatieve effect van de loonvoet in model IX C zou veroorzaakt kunnen worden door dit joint production effect. Ondanks dat deze uitbreiding van het theoretische model de empirische resultaten interpreteerbaar maken is het voorbarig om deze uitkomsten zonder meer te beschouwen als een bevestiging van de investeringsgoed benadering.

Van Doorslaer (1987, p. 125) uit eveneens zijn twijfels ten aanzien van de benadering van curatieve gezondheidszorg als investeringsgoed. Hij suggereert dat deze benadering meer adequaat is voor een verklaring voor de vraag naar preventieve zorg. Tot slot kunnen er twijfels geuit worden ten aanzien van de Cobb-Douglas specificatie van de produktiefunctie als een adequate weergave van produktieprocessen op micro-niveau (Van Montfort, 1980, p. 19). Bosworth (1976) die een overzicht geeft van de literatuur op dit terrein spreekt zelfs van een "empirical accident". Hiermee doelt hij op het feit dat een dergelijke specificatie van een produktiefunctie op geaggreerd niveau op adequate wijze empirische relaties tussen in- en outputs blijkt te beschrijven, echter dat aannamen zoals homogeniteit van produktiefactoren en constante produktie-elasticiteiten op micro-niveau weinig recht doen aan de realiteit. Er zijn de laatse decennia een aantal specifikaties van produktiefunkties ontwikkeld (Bosworth, 1976), die de hiervoor genoemde beperkingen loslaten. Zo heeft de zogenaamde jaargangenbenadering een belangrijke plaats ingenomen om de continue verandering in de produktietechnieken op een meer adequate wijze te beschrijven. In Grossman's toepassing zou dit impliceren dat de marginale produktiviteit van de inputs afneemt met de toename van de leefijd ("de jaargang") van de patiënt. Deze aanpassing van het theoretische model zou haar realiteitswaarde doen toenemen. Hier ligt nog een belangrijk terrein voor verder onderzoek binnen de gezondheidseconomie.

Noten

1) Op basis van (1) is het marginaal produkt van de gezondheidswoorraad te schrijven als:

$\mathrm{G}_{\mathrm{i}}=\mathrm{BCH}_{\mathrm{i}}^{-1}$ of in In notatie $\ln \mathrm{G}_{\mathrm{i}}=\ln \mathrm{BC}-(\mathrm{C}+1) \ln \mathrm{H}_{\mathrm{i}}$

De optimumconditie (2) is te schrijven als

$\ln \gamma_{i}=\ln G_{i}+\ln W-\ln I I$

Dit gecombineerd met de vergelijking voor $\ln G_{1}$ levert vergelijking (3) op. 
2) De subtitutie-elasticiteit $\sigma_{p}$ tussen de inputs $M_{i}$ en $T H_{i}$ is de ratio van de proportionele verandering in de inputverhouding en de proportionelle verandering in de relatieve prijzen van inputs:

$$
\sigma p=\frac{\left[d \frac{d M_{1}}{d T H_{1}}: \frac{M_{1}}{T H_{1}}\right]}{\left[\frac{d P_{1}}{d F_{1}}: \frac{P_{1}}{F_{1}}\right]}
$$

Onder de conditie van kostenminimalisatie zal deze in een Cobb-Douglas produktiefunctie ten alle tijden de waarde én aannemen, onafhankelijk van het outputniveau of de verhouding van de inputs (Heathfield en Wibe, 1987, p. 80).

3) Negatieve samenhangen van andere onafhankelijke variabelen met de afhankelijke variabele worden als gevolg hiervan versterkt en positieve samenhangen worden gedempt. 


\section{MACRO-ECONOMISCHE TIJDPRIJZEN}

"De toekomst van vandaag is het heden van morgen en het heden van vandaag het verleden van morgen." (Elias, 1985).

\subsection{INLEIDING}

In een artikel over onder andere de betekenis van tijdprijzen in de gezondheidszorg stelt Holtman (1972) dat de efficiëntie van deze sector niet beoordeeld kan worden zonder de waarde van de door de consument benodigde tijd in beschouwing te nemen. Hij berekent voor de Verenigde Staten dat in 1967 deze indirecte kosten $11 \%$ van de directe kosten van een gemiddelde opname in het ziekenhuis bedragen. DeVany e.a. (1983) berekenen op basis van gegevens uit 1977 dat de kosten van wachttijden van gebruikers van tandartsvoorzieningen in de Verenigde Staten ruim $5 \%$ bedragen van de directe kosten van deze voorzieningen.

In dit hoofdstuk wordt eveneens een berekening gemaakt van het kostenaandeel van tijdsbesteding bij medische consumptie. Hierbij worden een tweetal benaderingen gevolgd. De eerste is ondermeer gebaseerd op algemeen tijdbestedingsonderzoek, zoals dit in Nederland door het Sociaal Cultureel Planbureau uitgevoerd wordt. Deze benadering is globaal van karakter. De hier toegekende betekenis aan de begrippen directe en indirecte kosten wijkt af van de betekenis die beide begrippen hebben in bedrijfseconomische analyses, waar beide termen betrekking hebben op kosten die door de bedrijfshuishouding zelf gemaakt worden. In dit hoofdstuk wordt het begrip indirecte kosten echter gehanteerd zoals dat gebruikelijk is in maatschappelijke kostenbatenanalyses. In dergelijke analyses wordt onder indirecte kosten verstaan de kosten welke voortvloeien uit de doorwerking van de directe (interne) kosten in het maatschappelijk proces (Commissie voor de Ontwikkeling van Beleidsanalyse, 1975, p. 17). Hierbij kan het kostenbestanddeel verbonden met tijdinputs alleen op geaggregeerd niveau berekend worden. Bij de tweede benadering zijn de gegevens met 
betrekking tot de tijdsbesteding gebaseerd op waarnemingen of normtijden per consumptie-eenheid. Op deze wijze kan per consumptie-eenheid de verhouding tussen de directe en de indirecte kosten berekend worden. Dit zal afzonderlijk plaatsvinden voor de consumptiecategorieën, die in de hoofdstukken $3 \mathrm{t} / \mathrm{m} 6$ geanalyseerd zijn. In dit hoofdstuk zullen onder directe kosten de monetaire kosten verstaan worden, zoals die in het Financieel Overzicht Gezondheidszorg worden weergegeven en die in feite een sommatie zijn van de kosten, die door de huishoudingen in de gezondheidszorg gemaakt worden. Onder de indirecte kosten worden hier verstaan de kosten van de tijdsbesteding van de consument bij het gebruik van medische voorzieningen. De reiskosten, die eveneens tot de indirecte kosten gerekend kunnen worden, zijn door gebrek aan gegevens verder buiten beschouwing gelaten. Voor de ambulante medische zorg enerzijds en de klinische zorg van ziekenhuizen anderzijds worden afzonderlijk de totale indirecte kosten berekend.

In paragraaf 8.2. zullen de resultaten van de globale calculatie gepresenteerd worden en in paragraaf 8.3. die van de deelcalculaties per consumptiecategorie. In paragraaf 8.4. wordt met behulp van de eerder in deze studie geschatte tijdprijselasticiteiten een gevoeligheidsanalyse uitgevoerd. Hierbij wordt nagegaan wat het effect van een verandering van de tijdprijs is op de totale kosten. In paragraaf 8.5. zal een opsomming gegeven worden van mogelijk beleidstoepassingen van deze studie. Het hoofdstuk wordt afgesloten met een samenvatting.

\subsection{GLOBALE CALCULATIE VAN INDIRECTE KOSTEN}

Uit een in 1965 gehouden internationaal onderzoek naar tijdsbesteding bleek dat gemiddeld per week 10,5 minuten werden besteed aan medische consumptie buitenshuis (Szalai e.a., 1972, p. 576). In Nederland voert het Sociaal Cultureel Planbureau periodiek tijdbestedingsonderzoeken uit. De beschikbare gegevens van het meest recente onderzoek hebben betrekking op een in 1980 gehouden enquête. De gegevens hebben betrekking op een steekproef van 3.000 personen van 12 jaar en ouder, die geacht mogen worden representatief te zijn voor dat deel van de Nederlandse bevolking. Uiteindelijk namen 2730 personen deel aan de enquête. Vrouwen, personen tussen de 20 en 34 jaar evenals scholieren en studenten zijn hierin oververtegenwoordigd. Ondervertegenwoordigd zijn mannen, personen van 65 jaar en ouder, werklozen en arbeidsongeschikten (Knulst en Schoonderwoerd, 1983).

De waargenomen tijdsbesteding in tabel 8.1. heeft betrekking op ambulante woorzieningen, zoals huisarts, specialist in polikliniek, tandarts enz. Daarnaast dient vermeld te worden dat de genoemde tijden exclusief reis- en wachttijden zijn. Uit tabel 8.1. blijkt dat $19,1 \%$ van de geënquêteerden gemiddeld 80 minuten per week besteden aan medische verzorging buitenshuis. Dit komt neer op een gemiddelde tijdsbesteding van 15,28 minuten van de gehele steekproefpopulatie. Dit ligt ruim $45 \%$ hoger dan de waarneming die in 1965 in de eerder genoemde internationale studie gedaan werd. Hierbij dient opgemerkt te worden dat de eerder genoemde internationale studie beperkt was tot stedelijke gebieden en dat ook een aantal minder ontwikkelde landen hierin betrokken was, hetgeen een vergelijking bemoeilijkt. Verder blijkt uit de gepresenteerde gegevens dat een relatief kleiner deel van de ondervraagden $(9,6 \%)$ gemiddeld meer tijd (108 minuten) besteedt aan medische verzorging thuis. Dit komt neer op een gemiddelde van 10,37 minuten voor de gehele populatie. Wat betreft de 
Overzicht van tijdebestedingen aan medisohe verzorging bultenshuls on thuils in minuten per week $(N=2730)^{2}$

\begin{tabular}{|c|c|c|c|c|}
\hline & \multicolumn{2}{|c|}{ But tenshuis } & \multicolumn{2}{|c|}{ Thuils } \\
\hline & mannen & Wrouwen & mannen & vroutwen \\
\hline Totaal Generaal & 80 & $(19,1 \%)$ & 108 & $(9,6 \%)$ \\
\hline Totaal & $100(16,5 \%)$ & $65(21,6 \%)$ & $59(8,3 \%)$ & $146(10,8 \%)$ \\
\hline 12-24 jaar & $59(9,4 \%)$ & $67(14,4 \%)$ & $38(4,7 \%)$ & $125(7,3$ 蝶) \\
\hline 25-34 jaar & $129(16,0 \%)$ & $57(27,1 \%)$ & $38(6,1 \%)$ & $55(7,6 \%)$ \\
\hline $35-49$ jaar & $153(16,4 \%)$ & $69(22,6 \%)$ & $88(9,2 \%)$ & $153(13,0 \%)$ \\
\hline $50+$ & $73(24,5 \%)$ & $70(23,2 \%)$ & $58(13,3 \%)$ & $205(17,3 \%)$ \\
\hline
\end{tabular}

Percentage geeft onvang van deelpopulatie aan, die ook daadwerkelijk tija aan betreffende activiteiten besteedde.

2) Deze populatie bestond uit 1147 mannen en 1583 vrouwen.

Bron: Knulst en Schoonderwoerd, 1983.

verdeling van de tijdsbesteding woor medische verzorging buitenshuis over leeftijds(geslachtsgroepen blijkt het volgende. $\mathrm{Bij}$ mannen wordt voor de fractie die hieraan tijd besteedt $(16,5 \%)$ een gemiddelde tijdsbesteding gevonden van 100 minuten per week. Dit betekent gemiddeld woor alle mannen 16,5 minuten. Bij ondervraagde vrouwen ligt de fractie die hier tijd aan besteedt hoger $(21,6 \%)$, maar de gemiddelde tijd voor deze groep lag lager dan bij mannen. Dit betekent gemiddeld voor alle vrouwen 14,04 minuten.

Vervolgens blijkt uit de gepresenteerde gegevens dat over het algemeen de fractie van de populatie, die ook daadwerkelijk zegt tijd aan de genoemde activiteiten besteed te hebben, oploopt met de leeftijd van de geënquêteerden. Uitzondering hierop is de groep vrouwen in de leeftijd van $25 \mathrm{t} / \mathrm{m} 34$ jaar, dic tijd besteed heeft aan medische verzorging buitenshuis. Deze fractie ligt hoger dan bij de "oudere" leeftijdsgroepen. Het is aannemelijk dat dit samenhangt met medische consumptie, die verband houdt met vruchtbaarheild en zwangerschap. Tot slot valt op dat mannen van 50 jaar en ouder gegeven dat ze tijd besteden aan eén van beide vormen van medische consumptie relatief minder tijd hieraan besteden. Dit zou kunnen samenhangen met het feit dat mannen vanaf 50 jaar een aanmerkelijk grotere kans hebben op klinische hulp. Deze kans is zowel groter in vergelijking met jongere mannen alswel met vrouwen in dezelfde leeftijdscategorie (Van Brekel, 1985b).

Op basis van de in tabel 8.1. gepresenteerde gegevens en de Nederlandse bevolkingsstatistiek (Centraal Bureau voor de Statistiek, 1982) kan er een berekening gemaakt worden van de totale tijdsbesteding van de Nederlandse bevolking in de leeftijd van $16 \mathrm{t} / \mathrm{m} 64$ jaar. $^{1}$

Gecorrigeerd voor de gemiddelde tijdsbesteding per leeftijds- en geslachtsgroep komt dit neer op een totaal van 127.025 .912 uren op jaarbasis voor ambulante medische 
verzorging buitenshuis. Het dient vermeld te worden dat de gegevens met betrekking tot de tijdsbesteding in 1980 werden verzameld en de demografische gegewens betrekking hebben op 1 januari 1982. Daar verschuivingen in de samienstelling van tijdbudgetten in het algemeen zeer geleidelijk plaatsvinden (zie ook Knulst en Schoonderwoerd, $1983, p_{m} 43$ e.v.) wordt aangenomen dat de hierboven berekende totale tijdsbesteding een redelijke benadering is van de totale tijdsbesteding in 1981 .

Ten behoeve van de waardering van de tijdsbesteding worden de richtlijnen gehanteerd zoals deze door de Commissie voor de Ontwikkeling van Beleidsanalyse (1975) ten behoeve van tijdswaardering in kosten-batenanalyses zijn opgesteld. Deze houden ondermeer in dat tijdwinsten en -verliezen voor personen met een inkomen uit arbeid op $50 \%$ wan het gemiddeld brutoloon gesteld kunnen worden, indien aangenomen kan worden dat het aantal arbeidsuren hierdoor beïnvloed wordt. Hebben tijdwinsten en -verliezen geen invloed op het aantal gewerkte uren op basis waarvan een inkomen wordt verdiend, maar wel op de tijd die beschikbaar is voor huishoudelijke- en priveactiviteiten, in dat geval stelt de genoemde commissie voor om deze tijd te waarderen op basis van $35 \%$ van het gemiddelde besteedbaar inkomen van personen met een arbeidsinkomen. De walardering van de tijdsbesteding voor ambulante medische zorg zal per leeftijds-/geslachtsgroep, gecorrigeerd voor het percentage behorende tot de beroepsbevolking, plaatsvinden op basis van $50 \%$ van het gemiddelde brutoloon voor dat percentage van de betreffende groep die tot de beroepsbevolking behoort (gecorrigeerd voor geslacht). In 1981 bedroeg het gemiddelde bruto uurloon voor mannelijke en vrouwelijke werknemers $f$ 18,77 respectievelijk $f 14,57$ (Centraal Bureau voor de Statistiek, 1982, p. 313). De tijdsbesteding van het percentage van de leeftijds/geslachtsgroep die niet tot de beroepsbevolking behoort wordt gewaardeerd op basis van de genoemde $35 \%$ van het gemiddeld vrij besteedbaar inkomen per uur. Dit laatste is berekend op basis van het besteedbaar (toegerekend) looninkomen in 1981 (Centraal Planbureau, 1987) en het totale arbeidsvolume in arbeidsjaren in 1981 (Centraal Bureau voor de Statistiek, 1982, p. 255). Het besteedbaar inkomen uit arbeid bedroeg in 1981 op basis van een gemiddelde contractuele arbeidsdur van 1844 uur (Centraal Bureau voor de Statistiek, 1988) $f 9,85$ per uur.

De waardering van de tijdsbesteding ten behoeve van klinische zorg zal niet op basis van een partiële doorberekening van de alternatieve kosten, zoals bij de ambulante zorg, plaatsvinden maar op basis van een benadering van de volledige alternatieve kosten. Men mag immers veronderstellen dat ingeval van ziekenhuisopname de kosten van het tijdverlies niet benaderd worden door de opbrengsten van de zogenaamde marginale uren, maar dat deze eerder in de buurt liggen van de gemiddelde opbrengsten per uur. Het verlies van productieve uren per verpleegdag is benaderd door de gemiddelde contractuele arbeidsduur van de bevolking te middelen over alle dagen van het jaar. Op deze wijze wordt verdisconteerd dat een gedeelte van het tijdverlies in het weekend of tijdens vakantie plaatsvindt. In tabel 8.2 . staan op basis van de hierbowen beschreven waarderingsmethodiek de indirecte en directe kosten van de ambulante medische zorg weergegeven. De berekening heeft betrekking op de gehele Nederlandse bevolking in de leeftijd van $16 \mathrm{t} / \mathrm{m} 64$ jaar.

Uit de in tabel 8.2. gepresenteerde gegevens blijkt dat in volumetermen mannen in de leeftijd van $16 \mathrm{t} / \mathrm{m} 64$ jaar ruim 1,2 miljoen uren per week besteden aan medische consumptie buitenshuis. Voor vrouwen in dezelfde leeftijdscategorie ligt het totaal van deze tijdsbesteding met ruim 950 duizend uren enigszins lager. In waardetermen 
Trabel 8.2. Overzlcht van Indirecte kosten van ambulante medlsehe zorg (thulls en buttenshuls) In guldens

\begin{tabular}{|c|c|c|c|}
\hline \multicolumn{4}{|c|}{ Ambulante medlsiche zorg bultenshuls (mannen) } \\
\hline Leef t j jolsgroep & $\begin{array}{l}\text { tijdsbesteding in } \\
\text { uren per week. }\end{array}$ & $\begin{array}{l}\text { waardering } \\
\text { per uur }\end{array}$ & $\begin{array}{l}\text { ind recte } \\
\text { kosten }\end{array}$ \\
\hline $\begin{array}{l}16-24 \\
25-49 \\
50-64\end{array}$ & $\begin{array}{l}104.794 \\
962.564 \\
194.814 \\
\end{array}$ & $\begin{array}{r}+6.36 \\
+9.08 \\
+7.60\end{array}$ & $\begin{array}{lr}f & 666.020 \\
f & 8.743 .450 \\
t & 1.480 .781 \\
\end{array}$ \\
\hline Total & 1.262 .169 & & $f 10.890 .251$ \\
\hline \multicolumn{4}{|c|}{ Ambulante medleche zorg buitenshuie (vrouwwen) } \\
\hline $\begin{array}{l}16-24 \\
25-49 \\
50-64\end{array}$ & $\begin{array}{r}174.687 \\
617.072 \\
158.685 \\
\end{array}$ & $\begin{array}{l}f 5,29 \\
f 4,94 \\
f 4,18\end{array}$ & $\begin{array}{rr}f \quad 924.094 \\
f \quad 3.048 .335 \\
f \quad 662.938 \\
\end{array}$ \\
\hline Totaal & 950.444 & & $f 4.635 .367$ \\
\hline \multicolumn{4}{|c|}{ Ambulante medische zorg thuls (mannen) } \\
\hline $\begin{array}{l}16-24 \\
25=49 \\
50-64\end{array}$ & $\begin{array}{r}33.746 \\
222.110 \\
84.026 \\
\end{array}$ & $\begin{array}{l}f 6,36 \\
f 9,08 \\
f 7,60\end{array}$ & $\begin{array}{r}f 14.624 \\
f \quad 2.016 .759 \\
f \quad 638.597 \\
\end{array}$ \\
\hline Totaal & 339.882 & & $f \quad 2.869 .980$ \\
\hline \multicolumn{4}{|c|}{ Ambulante medische zorg thuis (vrouwen) } \\
\hline $\begin{array}{l}16-24 \\
25-49 \\
50-64\end{array}$ & $\begin{array}{r}165.217 \\
487.331 \\
346.537 \\
\end{array}$ & $\begin{array}{l}f 5,29 \\
f 4,94 \\
f 4,18\end{array}$ & $\begin{array}{rr}f & 873.999 \\
f & 2.407 .415 \\
f \quad 1.448 .525 \\
\end{array}$ \\
\hline Totaal & 999.085 & & $f \quad 4.729 .939$ \\
\hline Totaal generaal & $\begin{array}{l}\text { Indirecte kosten per } \\
\text { per }\end{array}$ & week & $\begin{array}{l}f 23.125 .537 \\
f 1.202 \mathrm{mill} \text { joen }\end{array}$ \\
\hline Totale directe & rosten van ambultante & & $f 8.881 \mathrm{mll}$ loen \\
\hline
\end{tabular}

1) Berekend op basis wan de gegevens uit tabel 8.1 en totale bevolking per leoftijdsIgeslachtsgroep (Centraal Bureau voor de statistiek, 1982).

21. Berekend op basis van een gewogen gemiddelde van $50 \%$ van het bruto uurloon van mannen respectievelijk vrouwen en $35 \%$ van het besteedbaar inkomen per uur. Weging vond plaats op basis van het percentage dat tot de beroepsbevolking gerekend kan Bronnen: worden per leeftijds-/ges lachtsgroep.

- Knulst, W. en L. Schoondenwoerd, 1983.

- Centraal Bureau voor de Statistiek. Statistisch Zakboek, 1982.

- Centraal Bureau voor de Statistlek, Sociaal-Economisch Maandistatistiek, 1988.

- Centraal Planbureau (1987), Centraal Economisch Plan, 1987.

- Ministerie van WVC (1987), Financieel Overzicht Gezondheidszorg en Maatschappelijk Welzijn, 1987. 
bedragen de kosten van deze tijdsbesteding voor de mannen bijna 11 miljoen gulden per week, terwijl deze voor vrouwen minder dan 5 miljoen gulden bedragen.

Dit grote verschil tussen beide groepen bij meting in waardetermen in vergelijking met de meting in volumetermen heeft een tweetal oorzaken. Ten eerste ligt het gemiddelde bruto-uurloon voor mannen in 1981 bijna $30 \%$ hoger dan voor vrouwen. Ten tweede is bij de groep mannen het deelnemingspercentage aan de beroepsbevolking hoger (72\%) dan bij vrowwen (27\%). Bij de fractie van de deelpopulatie, die behoort tot de beroepsbevolking vindt de waardering van de tijdsbesteding tegen $50 \%$ van het gemiddeld hogere bruto-uurloon plaats. Bij de fractie die niet behoort tot de beroepsbewolking vindl waardering plaats op basis van $35 \%$ van het gemiddeld lagere besteedbare inkomen. Ingeval van tijdsbesteding aan medische zorg thuis scoren de mannen in de beschouwde leeftijdsgroep met bijna 340 duizend uren per week aanmerkelijk lager dan de vrouwen met bijna 1 miljoen uren. In waardetermen is dit verschil als gevolg van dezelfde reden als bij de waardering van de tijdsbesteding van zorg buitenshuis minder groot. Voor mannen bedragen de indirecte kosten bijna 2,9 miljoen gulden en voor vrowwen ruim 4,7 miljoen gulden. Gesommeerd bedragen de indirecte kosten van ambulante medische zorg ruim 23 miljoen gulden per week. Op jaarbasis is dit 1.202 miljoen gulden. De directe kosten van ambulante zorg bedroegen in 19818.881 miljoen gulden (Ministerie van WVC, 1987). Als percentage van deze directe kosten bedragen de indirecte kosten van ambulante medische zorg derhalve $13,5 \%$.

Bij dit resultaat dienen nog enkele opmerkingen gemaakt te worden. In de eerste plaats betreft het hier directe kosten die ten behoeve van alle gebruikers van de ambulante gezondheidszorg zijn gemaakt. Dit terwijl de indirecte kosten alleen betrekking hebben op de leeftijdsgroep vanaf $16 \mathrm{t} / \mathrm{m} 64$ jaar. Een correctie hiervoor zou het percentage van de indirecte kosten uiteraard doen toenemen. In de tweede plaats is aangenomen dat personen met een inkomen uit arbeid hetzelfde tijdbestedingspatroon voor medische zorg hebben als personen zonder een betaalde baan. Waarschijnlijk is dat de eerste groep hier gemiddeld minder tijd aan besteedt. Hierdoor vindt een zekere overschatting van het aandeel van de indirecte kosten plaats.

In tabel 8.3. wordt een overzicht gegeven van de indirecte kosten van de klinische zorg van ziekenhuizen. Hierbij zijn de gegevens per leeftijds-/geslachtsgroep op jaarbasis weergegeven. Uit de tabel blijkt dat het aantal verpleegdagen voor mannen in de leeftijdscategorie van $16 \mathrm{t} / \mathrm{m} 64$ jaar ongeveer 4,2 miljoen bedraagt en voor vrouwen meer dan 5,8 miljoen. De indirecte kosten per verpleegdag ligt voor mannen in elke leeftijdscategorie hoger dan voor vrouwen. Dit wordt ook nu weer veroorzaakt door het relatief hogere percentage mannen dat behoort tot de beroepsbevolking én het relatief hoger bruto uurloon woor mannen in vergelijking tot vrouwen die een inkomen uit arbeid genieten. Voor de populatie mannen als geheel bedragen de indirecte kosten van klinische zorg ruim 352 miljoen gulden en voor de populatie vrouwen ruim 335 miljoen gulden. Het totaal van de indirecte kosten op jaarbasis bedraagt derhalve ruim 687 miljoen gulden oftewel gemiddeld $f 68,41$ per verpleegdag.

De directe kosten per verpleegdag bedroegen in $1981 f 458,-.^{2}$ Als percentage van de directe kosten bedroegen de indirecte kosten van klinische zorg in 1981 15\%. $\mathrm{Bij}$ de calculatie van de indirecte kosten is aangenomen dat personen die behoren tot de 
Tabel 8.3. Indrecte kosten van klnieche 20 rg in zlekenhulzen in 1981 in miljoen guldens

Mannon

leeftijdsgroep

aantal verpleeg-

indirecte kosten

totale indi-

dagen per laar per verpleegdag

recte kosten

per jaar in

miln guldens

$16-24$

617.634

$f 71,10$

43.9

1.789 .986

$f 91,60$

164,0

$50-64$

$\frac{1.791 .710}{4.199 .330}$

$f 80,45$

144,2

352,1

\section{Vrouwen}

$16-24$

$25-49$

852.674

3.203 .741

$50-64$

$\frac{1.789 .184}{5.845 .599}$

$+60,60$

$f 58,50$

51,6

$f 53,70$

187,3

96,2

335,1

Toteal generaal

10.044 .929

687,2

Gemiddelde indirecte kosten per verpleegdag: $f 68,41$

Bronnen:

- Centraal Bureau voor de Statistiek (1985), Dlagnose Statistiek Ziekenhuizen, 19811982.

- Stichting Medische Registratie: (1982), Jaarboek, 1982.

- Centraal Bureau voor de Statistiek (1982), Statistisch Zakboek, 1982.

- Centraal Planbureau (1987). Centraal Economisch Plan, 1987.

- Centraal Bureau voor de Statistiek (1988), Sociaal Economisch Maandstatisttek. februari 1988.

beroepsbevolking hetzelfde consumptiepatroon hebben als personen die niet deel uitmaken wan de beroepsbevolking. In werkelijkheid ligt dit waarschijnlijk lager (zie ook hoofdstuk 6). Als dit zo is vindt er een zekere overschatting van de indirecte kosten plaats. Anderzijds zijn in deze paragraaf de kosten van vervoer door gebrek aan gegevens niet opgenomen in de indirecte kosten. Deze vervoerskosten bestaan uit de gewaardeerde reistijd en de kosten van het eventueel gebruikte transportmiddel. Als gevolg hiervan treedt er een zekere onderschatting van de indirecte kosten op die met name bij de ambulante zorg substantieel kan zijn.

\subsection{INDIRECTE KOSTEN PER CATEGORIE VAN MEDISCHE CONSUMPTIE}

In deze paragraaf zal zoveel mogelijk worden aangesloten bij de in hoofdstuk $3 \mathrm{t} / \mathrm{m} 6$ onderscheiden categorieẽn van medische consumptie. Achtereenvolgens zal voor huisartsenhulp, farmaceutische hulp, specialistische hulp en ziekenhuisopname een 
calculatie platsvinden van de directe en indirecte kosten per consumptie-eenheid. Hierbij zal door gebrek aan gegevens veelvuldig met grove benaderingen volstaan worden. Voorop staat dan ook het verkrijgen van een indicatie van de verhouding tussen de directe en indirecte kosten. Enige voorzichtigheid bij de interpretatie van de gegevens is dan ook geboden.

\section{Huisartsenhulp}

In tabel 8.4 . is een overzicht gegeven van de berekening van de directe en indirecte kosten van een huisartsconsult. De directe kosten zijn gemiddeld over alle contacten, waarbij geen differentiatie is gemaakt naar contacten in de praktijk van de huisarts, telefonische contacten of contacten bij de patiënt thuis (visite). De berekening van de directe kosten is gebaseerd op het gemiddeld aantal contacten per persoon per jaar

Tabel 8.4. Rellevanite gegevens met betrekking tot directe en Indirecte kosten van hulsartsconsulten in 1981

Totale directe kosten $(m / n . \text { gld })^{1}$

Gemiddeld aantal contacten per persoon ${ }^{2}$

Aantal inwoners in Nederland $(\mathrm{m} / \mathrm{n} .)^{3}$

Gemiddelde directe kosten per contact $(g(d)$

Gemiddelde tijdsbesteding per consult (minuten) ${ }^{4}$

Gemiddeld tijdkosten per uur ${ }^{5}$

Gemiddelde indirecte kosten per consult (gld)

4,20

De gemiddelde indirecte kosten als \% van gem.dir.kosten

1) Bron: Ministerie van WVC (1987), Financieel Overzicht Gezondheidszorg en Matschappel lj ke dienstverlening, 1987.

2) Bron: Centraat Bureau voor de Statistiek (1984), Compendium Gezondheidsstatistiek Nederland, 1984,

3) Bron: Centraal Bureau voor de Statistiek (1982), Statistisch Zakboek, 1982.

4) Bron: Centraal Bureau voor de Statistiek (1981), Gezondheidsenquête, 1981.

5) Bron: Centraal Bureau voor de Statistiek (1982), Statistisch Zakboek, 1982; Centraal Planbureau (1987), Centraal Economisch Plan, 1987; Centraal Bureau voor de Statistiek (1988), Soctaal-Economi sche Maandstatistiek, 1988.

$(3,6)$ verkregen uit de Gezondheidsenquête van het CBS. De gemiddelde directe kosten voor een contact blijken $f 26,70$ te bedragen. De berekening van de indirecte kosten is gebaseerd op de gemiddelde tijdsbesteding van de patiënt bij een contact in de praktijk van de huisarts, verder consult te noemen. Deze tijdsbesteding bedroeg gemiddeld 42,27 minuten in 1981 . Bij een waardering van deze tijd op basis van gemiddelde alternatieve kosten van $f 5,97$ komen de indirecte kosten van een consult op $f 4,20$. De opportuniteitskosten per uur zijn evenals in de vorige paragraaf berekend op basis van $50 \%$ van het gemiddeld bruto-uurloon $(f 16,97)$ voor dat deel van de 
populatie dat tot de beroepsbevolking behoort (50\%) (Centraal Bureau voor de Statistiek, 1982). Voor het owerige deel van de populatie vindt de waardering plaats op basis van 35\% van het vrij besteedbaar inkomen per uur $(f 9,85)$ (zie voor berekening vorige paragraaf). Indien de directe kosten van een contact gebruikt worden als een benadering voor die van een consult bedragen de indirecte kosten als percentage van de directe kosten $16 \%$.

\section{Farmaceutische hulp}

Deze vorm van medische hulp is bij de analyse van het consumentengedrag aangeduid met gebruik van medicijnen op recept c.q. niet op recept. De navolgende berekening is beperkt tot het gebruik en de kosten van medicijnen op recept. Een probleem bij het relateren van de indirecte kosten voor de gebruiker aan de directe kosten voor de leverancier, zit in het verschil van meeteenheden van de volumeterm. De directe kosten aan de leverancierszijde zijn gekoppeld aan een aflevering, terwijl de indirecte kosten aan de gebruikerszijde over het algemeen gekoppeld zijn aan het afhalen van een recept. Op een recept kunnen meerdere afleveringen voorkomen. De gegevens met

Tabel 8.5. Relevante gegevens met betrekking tot directe en Indirecte kosten van tarmaceutleche hulp in 1981

\begin{tabular}{|c|c|}
\hline Totale directe kosten $\left(\mathrm{m} \ln \mathrm{g}(\mathrm{d})^{1}\right.$ & 2230 \\
\hline Gemiddelde directe kosten per aflevering $(g l d)^{2}$ & 9.02 \\
\hline Gemiddeld aantal afleveringen per recept $t^{2,3}$ & 3,98 \\
\hline Gemiddelde directe kosten per recept (gld) & 35,89 \\
\hline Gemiddelde tijdsbesteding voor afhalen recept (minuten) & 42,27 \\
\hline Gemiddelde tijdkosten per uur $(g l d)^{5}$ & 5,97 \\
\hline Gemiddelde indirecte kosten per recept (gld) & 4,20 \\
\hline De gemiddelde indirecte kosten als \% van de gem.dir.kosten & $12 \%$ \\
\hline
\end{tabular}

1) Bron: Ministerie van WV (1985). Financieel Overzlcht Gezondheidszorg en Maatschappeli ke Dienstverlening, 1985

2) Bron: Ziekenfonds raad (1981), Jaarverstag 1981.

$3)$ Bron: Van Brekel, 1983.

4) Bron: Centraal Bureau voor de Statistiek (1981), Gezondheldisenquete, 1981.

5) Bron: Centraal Bureau voor de statistlek (1982), Statistisch Zakboek, 1982, Centraal Planbureau (1987), Centraal Economisch Plan, 1987; Centraal Buireau voor de Statistiek (1988), Sociaal-Economische Maandstatistiek; 1988. 
betrekking tot de directe kosten zijn afkomstig wan ziekenfondsverzekerden. Overeenkomstig het FOGM wordt verondersteld dat de kosten en het verbruik per ziekenfondsverzekerde gelijk zijn aan die per particulier verzekerde. $O p$ basis van gegevens uit de Gezondheidsenquête 1981 is het aantal keren benaderd, dat iemand in een jaar medicijnen krijgt voorgeschreven op recept $(4,03$ keer). In werkelijkheid ligt dit waarschijnlijk hoger, omdat indien binnen 14 dagen meer dan én keer een recept is voorgeschreven, dit slechts als eén recept geteld wordt. Uit gegevens van de Ziekenfondsraad blijkt dat er gemiddeld 16,02 afleveringen per verzekerde per jaar plaatsvinden. Met behulp hiervan zijn het aantal afleveringen per recept en de directe kosten per recept berekend.

Voor wat betreft de gemiddelde tijdsbesteding van een consument voor het afhalen van een recept zijn geen gegevens beschikbaar. Als benadering hiervoor is de gemiddelde tijdsbesteding voor een huisartsconsult genomen. In werkelijkheid kan het afhalen van de medicijnen op uiteenlopende wijzen plaatsvinden. Uit gegevens van de Ziekenfondsraad (1983) blijkt dat 19\% van de farmaceutische hulp in guldens gemeten via een apotheekhoudende huisarts verstrekt werd in 1981. In sommige gevallen kan de patiènt de voorgeschreven medicijnen direct meenemen, soms echter moet hij hiervoor terugkomen. Dit geldt ook voor verstrekkingen via de apothekers. Deze laatsten brengen soms de afleveringen bij de patiënt thuis. Tengevolge van het ontbreken van gegevens over de werkelijke tijdsbesteding is de gemiddelde tijdsbesteding voor een huisartsconsult als een minimum te beschouwen. Waardering van deze gemiddelde tijdsbesteding die op gelijke wijze plaatsvindt zoals beschreven bij huisartsenhulp, leidt tot een benadering van de indirecte kosten per recept ten bedrage van $f 4,20$. Als percentage van de directe kosten bedragen de indirecte kosten $12 \%$.

De hier gevolgde benadering impliceert dat ten behoeve van een calculatie van de totale indirecte kosten van de in deze studie beschouwde consumptiecategorieën de indirecte kosten van farmaceutische hulp niet zonder meer meegenomen kunnen worden, teneinde dubbeltellingen te voorkomen.

\section{Specialistische hulp}

In tabel 8.6. staat een overzicht weergegeven van de berekening van de directe en indirecte kosten van een poliklinisch contact met een specialist. De directe kosten hebben betrekking op niet-klinische specialistische hulp. Op grond van gegevens zoals die in het FOGM staan weergegeven, kan het klinische en niet-klinische deel van de specialistische hulp niet onderscheiden worden. Ook op basis van het Landelijk Informatie Systeem Ziekenfondsen (LISZ) is voor een deel van de specialistische hulp, met name die binnen tariefgroep. III valt, dit onderscheid niet te maken. Op grond hiervan is ervoor gekozen om de directe kosten van niet-klinische specialistische hulp af te leiden van de gegevens die de Stichting KLOZ Informatiesysteem Gezondheidszorg voor particulier verzekerden registreert. Hieruit blijkt dat de gemiddelde kosten van niet-klinische hulp van particulier verzekerden $f 178,68$ bedroeg in 1981 (Stichting KLOZ, 1981). Op basis van de Gezondheidsenquête blijkt dat het gemiddeld aantal specialistconsulten voor deze groep 156 per 100 verzekerden bedroeg. De gemiddelde directe kosten per consult zijn derhalve gelijk aan $f 114,-$. Op basis van het gegeven dat de tarieven voor ziekenfondsverzekerden gemiddeld $100 \%$ lager liggen (Stichting KLOZ, 1981, p. 42) en aannemende dat deze groep een qua samenstelling vergelijkbaar consumptiepatroon heeft, wordt aangenomen dat de directe kosten van een 
Tabel 8.6.

Relevante gegevens met betrekking tot directe en Indirecte kosten van nletKlinische specialletische hulp in 1981

Totale directe kasten ( $m$ ln gld $)^{1}$

1720

Totaal aantal niet-klinische specialistenconsul ten

$(x, 1000)^{1}$

23064

Gemiddelde directe kosten per polikl. bezoek (gld)

74,56

Gemiddelde tijdsbesteding per bezoek (minuten) ${ }^{2}$

68,35

Gemiddelde tijdkosten per uur $\left(g(d)^{2}\right.$

5,97

Gemiddelde indirecte kosten per pollkl, bezoek (gld)

6,67

De gem. undir.kosten als \% van de gemid.dir. kosten

$10 \%$

1) Bron: Stichting KLOZ Informatiesysteem Gezondheidszorg (1982), Jaarboek, 1981.

2) Bron: Centraal Bureau voor de Statistiek 1981), Gezondheldsenquête $\$ 981$ en vissers, 1983.

3) Bron: Centraal Bureau voor de statistiek (1982), Statistisch Zakboek, 1982; Centraa! PLan Bureau (1987), Centraal Economisch PLan, 1987; Centraal Bureau voor de Statistiek (1988), Saciaal-Economische Maandstatistiek, 1988.

specialistconsult voor ziekenfondsverzekerden gemiddeld genomen gelijk is aan $f 57$, Verder blijkt uit de Gezondheidsenquête dat het aantal specialistconsulten per 100 ziekenfondsverzekerden 164 bedroeg. Met behulp van deze gegevens zijn de totale directe kosten van niet-klinische specialistische hulp in zijn totaliteit en per consult benaderd. Deze bedragen voor 19811720 miljoen gulden respectievelijk $f$ 74,56.

Er zijn in Nederland behalve op basis van een aantal case-studies geen of slechts gebrekkige gegevens bekend met betrekking tot de gemiddelde tijdsbesteding voor cen specialistconsult. De consumentenbond heeft in 1974 en 1977 onder haar leden een enquête gehouden waaruit bleek dat de gemiddelde wachttijd 37 respectievelijk 38 minuten bedroeg (Consumentengids, 1974 en 1977). Vissers (1977) rapporteerde op basis van een uitgebreid wachttijdenonderzoek in een algemeen ziekenhuis van 900 bedden een gemiddelde wachttijd van 39 minuten en een gemiddelde consultduur van 10 minuten. Spangenberg (1979) vond in een wachttijdenonderzoek in een Amsterdams ziekenhuis een gemiddelde verblijfsduur in het ziekenhuis van 67 minuten, waarvan 47 minuten als wachttijd werd doorgebracht. Minderhoud (1980) vond bij een onderzoek in een drietal ziekenhuizen een gemiddelde wachttijd van 15 minuten na het afspraaktijdstip. Tevens bleken patiënten gemiddeld 8 minuten voor het afspraaktijdstip aanwezig te zijn en bedroeg de gemiddelde verblijfisduur in de spreekkamer ruim 14 minuten. Bij een onderzoek in een ziekenhuis in Emmen in 1984 (Werkgroep, 1984) bleek dat patiënten gemiddeld 17,8 minuten moesten wachten tussen het tijdstip van afspraak en het werkelijke begin van de behandeling. 
Daar de hierboven aangehaalde onderzoeken nogal uiteenlopende uitkomsten laten zien is het niet zinvol deze te gebruiken ten behoeve van de berekening van de indirecte kosten van een poliklinisch specialistconsult. Als alternatief voor dit gebrek aan representatieve gegevens wordi een normatieve wachttijd gebruikt. Deze is een nuancering van die welke is vastgesteld door de Normencommissie Ziekenhuispoliklinieken. Deze commissie stelt dat de gemiddelde wachttijd niet langer dan 15 minuten mag zijn, waarbij $75 \%$ van de patiënten binnen 30 minuten aan de beurt dient te zijn (Nationale Ziekenhuisraad e.a., 1985). Vissers (1983) stelt dat deze norm nogal rigide en slecht toetsbaar is. Hij stelt een meer gedifferentieerde norm voor die inhoudt dat $50 \%$ van de patiënten niet langer dan 15 minuten dient te wachten, $75 \%$ niet langer dan 30 minuten en $95-97 \%$ minder dan 60 minuten. Op basis van deze meer gedifferentieerde norm komt de gemidldelde wachttijd op 22 minuten per patiënt. Deze laatste normtijd die in Engeland (Department of Health and Social Security, 1985) gehanteerd wordt en het meest realistisch lijkt, wordt hier gekozen om de gemiddelde wachttijd te benaderen. Voor de gemiddelde behandeltijd is een normtijd van 15 minuten gekozen, die veelvuldig in afspraaksystemen gehanteerd wordt. De gemiddelde reistijd is berekend op basis van de gemiddelde afstand tot het dichtsbijzijnde ziekenhuis en een genormeerde reistijd van 2,5 minuten per kilometer. De gemiddelde afstand tot het dichtsbijzijnde ziekenhuis bleek voor alle respondenten van de Gezondheidsenquête 1981 gemiddeld 6,11 kilometer te bedragen. Op basis van de aangenomen gemiddelde normtijd per kilometer bedraagt de gemiddelde reistijd (vice versa) 31 minuten.

Tabel 8.7.

Felevante gegevens met betrekking tot directe en Indirecte kosten van een zlekenhulsopname In 1981

Totale directe kosten $\left(m \ln g(d)^{1}\right.$

Totaal aantal verpleegdagen $(x 1000)^{2}$

21919

Gemiddeld aantal verpleegdagen per opname ${ }^{2}$

Gemiddelde directe kasten per opname ( $g(d)$

Gemiddelde indirecte kosten per opname $(g l d)^{3}$

Bron: Ministerte van WV (1985), Financileel Overzicht van de Gezondheidszorg en Matschappelijke Dienstverlening, 1985.

2) Bron: Centraal Bureau voor de Statistiek (1984), Compendium Gezondheidsstat istiek Neder land, 1984.

3) Bron: Centraal Bureau voor de Statistiek (1981), Gezondheidsenquête 1981. 
Sommatie van de hierboven vermelde reis-, wacht- en behandeltijd leidt tot een gemiddelde tijdsbesteding van 68 minuten voor een specialistconsult. Waardering van deze tijdsbesteding op basis van de gemiddelde alternatieve kosten per uur leidt tot indirecte kosten van $f 6,67$ yoor een specialistconsult. Het aandeel hiervan in de directe kosten bedraagt $10 \%$.

\section{Ziekenhuisopname}

De in tabel 8.7. gebruikte gegevens hebben betrekking op zowel algemene, categorale als academische ziekenhuizen. De gemiddelde directe kosten per verpleegdag bedragen 458 gulden. ${ }^{2}$ Bij een gemiddelde verpleegduur van 13,7 dagen bedragen de directe kosten per opname 6275 gulden. In tabel 8.3. in paragraaf 8.2. is reeds een calculatie weergegeven van de berekening van de indirecte kosten per verpleegdag. Deze bedragen $f 68,41$. De indirecte kosten van een gemiddelde opname bedragen derhalve $f 937,-$ De indirecte kosten per opname bedragen als percentage van de directe kosten, uiteraard evenals bij de verpleegdag $15 \%$.

Ter afsluiting van deze paragraaf worden in tabel 8.8. de indirecte kosten van de hier beschouwde 4 medische consumptiecategorieën nog eens weergegeven als percentage van de directe kosten. Deze variëren van $10 \%$ voor een specialistenconsult tot $16 \%$ voor

Tabel 8.8. Indirecte kosten als percentage van de directe kosten voor een aantal
consumptlecategorieèn

\begin{tabular}{lr} 
Huisartsconsult & $16 \%$ \\
Farmaceutische hulp & $12 \%$ \\
Special istconsult (niet-klinisch) & $10 \%$ \\
Ziekenhuisopname & $15 \%$ \\
\hline
\end{tabular}

een huisartsconsult. Op grond hiervan kan gesteld worden dat de indirecte kosten van tijdsbesteding aan medische consumptie een substantieel deel van de totale maatschappelijke inputs vormen. 


\subsection{GEVOELIIGHEIDSANALYSE}

In deze paragraaf zal onderzocht worden in welke mate de directe kosten van gezondheidszorg reageren op een verandering in de tijdprijzen. Deze gevoeligheidsanalyse vindt plaats voor de in de vorige paragraaf besproken consumptiecategorieen. Hierbij wordt verondersteld dat alle andere variabelen die van invloed zijn op de medische consumptie constant blijven.

Tabel 89. Kosteneffecten wan een denkbeeldige afmamie van de tfdprijzen met 10\% (in mlng gld)

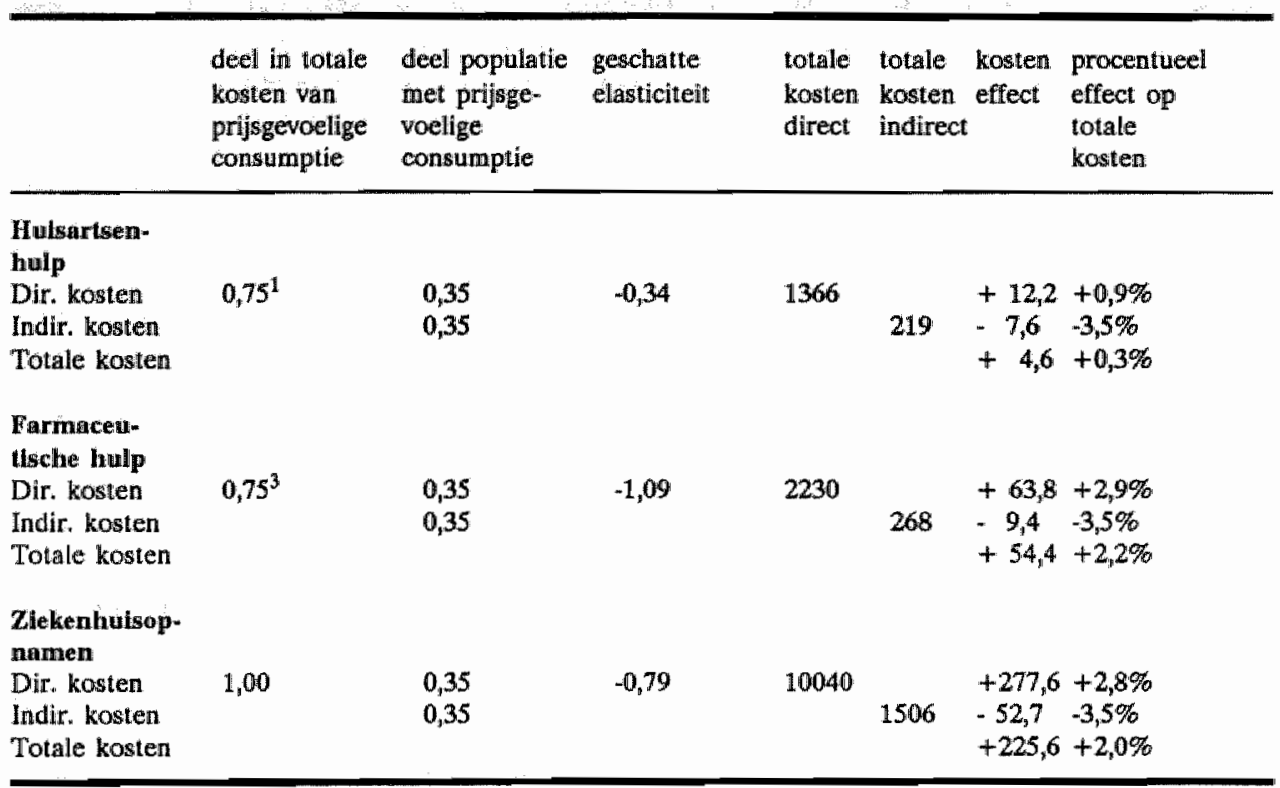

1) Aandeel wan de huisartsconsulten op eigen initiatief in het totaal aantal consulten Bron: Centraal Bureau woor de Statistiek (1981), Gezondheidsenquete 1981.

2) Aandeel wan de bevolking met een eigen inkomen uit arbeid. Bron: Centraal Bureau voor de Staltistiek (1982), Statistisch Zakboek 1982.

3) Aandeel van medicijnen die woorgeschreven zijn door de huisarts. Bron: Centraal Bureau voor de Statistiek (1981), Gezondheidsenquete 1981.

Bij de vitvoering van deze gevoeligheidsanalyse is de volgende procedure gevolgd. Op de eerste plaats is met behulp van de analyses in de hoofdstukken $3 \mathrm{t} / \mathrm{m} 6$ nagegaan voor welke consumptiecategorieën er significante tijdprijseffecten zijn vastgesteld. Vervolgens is benaderd welk deel van de kosten betrekking heeft op deze "gevoelige" categorie. De volgende stap is de bepaling van dat deel van de consumentenpopulatie, waarbij tijdprijseffecten zijn vastgesteld. Op basis hiervan wordt benaderd welk deel van de kosten van de prijsgevoelige consumptie door deze deelpopulatie veroorzaakt wordt. Op dit laatste kostenbestanddeel wordt het effect van een denkbeeldige tijdprijsverandering middels de eerder geschatte elasticiteiten berekend. De voorgaande calculatie heeft betrekking op het effect van een verandering in de gemiddelde tijdprijzen op de directe kosten. Een procentuele verandering van de tijdprijs leidt uiteraard tevens tot eenzelfde procentuele wijziging van de indirecte kosten van de prijsgevoelige consumptie. 
Het saldo van de mutaties in beide kostenbestanddelen is het uiteindelijk effect van de veranderingen in de tijdprijs op de totale kasten. In tabel 8.9. staan de kosteneffecten weergegeven van een afname van de tijdprijs met $10 \%$. Alvorens deze effecten te bespreken wordt er ingegaan op een aantal aannames die aan deze tabel ten grondslag liggen. Op de eerste plaats gaat het om effecten onder de ceteris paribus conditie. Omdat de geschatte elasticiteiten betrekking hebben op de populatie met een inkomen uit arbeid wordt aangenomen dat de consumptie van alleen dat deel van de Nederlandse bevolking (35\%) prijsgevoelig is (Centraal Bureau voor de Statistiek, 1982, p. 119). Hierbij is tevens verondersteld dat deze populatie een evenredig deel van de totale directe kosten per consumptiecategorie veroorzaakt. Bij huisartsenhulp is verondersteld dat de directe kosten van een consult op eigen initiatief gelijk zijn aan die van een consult niet op eigen initiatief. Ten aanzien van farmaceutische hulp zijn de directe kosten verdeeld naar rato van de recepten op voorschrift van de huisarts en de specialist. Specialistische hulp wordt op grond van de bevindingen in hoofdstuk 5 hier verder buiten beschouwing gelaten. Daar is immers gesteld dat als gevolg van de gebrekkige waarneming van de feitelijk benodigde tijd het zeer twijfelachtig is of de schattingsresultaten tijdprijseffecten weerspiegelen.

Uit de berekeningen blijkt dat een tijdprijsverlaging met $10 \%$ leidt tot een toename van de directe kosten van huisartsenhulp met $0,9 \%$, van farmaceutische hulp met $2,9 \%$ en van ziekenhuisopname met $2,8 \%$. De indirecte kosten nemen uiteraard in alle gevallen af. Voor de drie hiervoor genoemde consumptiecategorieèn wordt er per saldo een stijging van de totale kosten gevonden. De geringe procentuele stijging van het relatief grote aandeel van de directe kosten in de totale kosten overtreft de grotere procentuele daling van het relatief kleinere aandeel van de indirecte kosten. Bij het tijdprijseffect op de kosten van ziekenhuisopname dient opgemerkt te worden, dat de betreffende elasticiteit geschat is op basis van variatie in de tijdswaardering per tijdseenheid (zie paragraaf 6.1.). Dit betekent dat vooralsnog het hier gecalculeerde effect alleen aan een mutatie in de tijdswaardering mag worden toegekend en niet aan een verandering in de gemiddelde verpleegduur.

Het zij nogmaals gesteld dat deze calculaties met een zekere zin tot relativering geïnterpreteerd dienen te worden, vanwege de vele veronderstellingen die er aan ten grondslag liggen en de statistische betrouwbaarheidsmarges waarmee met name de geschatte elasticiteiten behept zijn. Tot slot leidt de aanname dat alleen de consumptie van de populatie met een inkomen uit arbeid gevoelig is voor veranderingen in tijdprijzen tot een onderschatting van de werkelijke effecten. Immers in de hoofdstukken $3 \mathrm{t} / \mathrm{m}$ 6 is verschillende malen angetoond dat de medische consumptie van andere tijdbestedingsgroepen evencens gevoelig is voor veranderingen in de tijd benodigd voor het gebruik van voorzieningen.

\subsection{BELEIDSIMPLICATIES}

In dit onderzoek is gebleken dat tijdprijseffecten een significante betekenis hebben voor de vraag naar een aantal medische voorzieningen. Daarnaast blijken de kosten van tijdinputs substantieel te zijn in verhouding tot de kosten van de inputs die door de aanbieders gemaakt worden. Bij de beantwoording van de vraag wat dit nu betekent voor beleid wordt een onderscheid gemaakt tussen overheidsbeleid en instellingsbeleid. $\mathrm{Bij}$ het eerste ligt over het algemeen de nadruk op collectieve doelen zoals die binnen 
een nationaal gezondheidszorgbeleid geformuleerd worden. Bij de laatste ligt de nadruk meer op instrumenten die hel instellingsmanagement ter beschikking staan bij het intern beheer. Een instelling wordt hier ruim opgevat en omwat tevens de praktijk wam een individuele arts.

\section{Overheidsbeleid}

De verdeling van het gebruik van voorzieningen en de toegankelijkheid ervan is met name na de Tweede Wereldoorlog een bielangrijk aandachtsgebied van het owerheidsbeleid. Een centraal instrument om de doelstellingen op dit terrein te realiseren is in Nederland het wettelijk verzekeringsstelsel. Het Ziekenfondsbesluit (1941) em later de Algemene Wet Bijzondere Ziektekosten (AWBZ) (1967) dienden ondermeer om een gelijke toegankelijkheid van de voorzieningen voor verschillende inkomensgroepen te garanderen. Het reduceren of zelfs volledig elimineren van directe betalingen (geldprijzen) bij gebruik bevoordeelt de groepen met een lagere tijdswaardering relatief meer. Immers voor dergelijke groepen neemt de totale prijs relatief sterker af. Het omgekeerde treedt echter op indien geldelijke eigen bijdragen geïntroduceerd worden. Het prijseffect hiervan zal relatief sterker zijn naarmate de dijdprijs lager is. Dit betekent dat het gebruik van groepen met een lagere tijdswaardering relatief sterker beinvloed zal worden door de introductie van nominale eigen bijdragen. Sinds het begin van de jaren ' 80 zijn er een hele reeks van eigen bijdragen in de gezondheidszorg geintroduceerd (zie hiervoor de jaarverslagen van de Ziekenfondsraad). In relatie tot de doelstelling van gelijke toegankelijkheid is het op zijn plaats om de verdelingseffecten van deze maatregelen verder te onderzoeken.

De invoering van de eigen bijdragen heeft o.a. ten doel de collectieve lasten van de gezondheidszorg terug te dringen. Dit wordt op twee manieren gerealiseerd. Enerzijds door de totale kosten te verlagen en anderzijds door overheveling van de financiering van collectieve middelen naar particuliere betalingen o.a. middels de introductie van eigen bijdragen (zie voor een overzicht van andere instrumenten Van der Made en Janssen, 1989). Juist omdat aan dergelijke maatregelen overwegingen ten grondslag liggen met betrekking tot een genormeerde verdeling van collectieve en particuliere uitgaven lijkt het op zijn plaats om indirecte kosten van tijdinputs van gebruikers in dergelijke overwegingen te betrekken. Immers, zoals uit de berekeningen eerder in dit hoofdstuk blijkt vormen de kosten van tijdinputs een substantieel deel van de totale kosten van de gezondheidszorg.

De planning van voorzieningen is een volgend belangrijk terrein van overheidsbeleid. In Nederland is een praktijk gegroeid waarbij de capaciteiten van de uiteenlopende voorzieningen genormeerd zijn op basis van aantallen inwoners per verzorgingsgebied. Deze normen zijn o.a. onafhankelijk van de bevolkingsdichtheid. Dit leidt ertoe dat in gobieden met een relatief lage bevolkingsdichtheid gebruikers over het algemeen langere afstanden moeten overbruggen en daarmee hogere tijdkositen hebben. Juist nu in Nederland als gevollg van een verlaging van de beddennorm een nog verdere concentratie van intramurale voorzieningen optreedt is aandacht voor deze effecten op regionale verschillen in indirecte kosten op zijn plaats. Een mogelijke oplossing hiervoor is het inrichten van poliklinische voorzieningen onafhankelijk van het ziekenhuis en dichter bij woonconcentraties. Daarnaast kunnen eerste lijnsvoorzieningen in gebieden met relatief lage bevolkingsdichtheden mobiel gemaakt worden. $\mathrm{Bij}$ dit laatste kan men denken aan het houden van spreekuren in plaatsen waar geen 
huisartspraktijk gevestigd is. Uiteraard doet zich bij de overweging ten aanzien van de hiervoor genoemdle beleidsopties het dilemma voor van de afweging tussen het streven naar beheersing wan de directe kosten en het streven naar gelijke toegankelijkheid (Mooney, 1983).

\section{Instellingsbeleid}

Binnen de tijdinputs kan onderscheid gemaakt worden tussen tijd benodigd voor reizen, wachten en behandelen. Met name de wacht- en behandeltijd kunnen door het instellingsmanagement beïnwloed worden. De Vany e.a. (1983) ontwikkelden een model voor bedrijven die diensten verlenen die niet in voorraad opgeslagen kummen worden en waarbij de tijd van de klant als één van de productiefactoren beschouwd kan worden. Zij leiden hieruit af dat onder de conditie van volledige mededinging in de evenwichtssituatie de kosten van de totale tijdinputs van de klant, die samenhangen met een verlaging van onbenutte capaciteit, gelijk zijn aan de hiermee gepaard gaande kostenbesparing resp. lagere prijzen. Dit betekent dat in een dergelijke situatie bij een verlaging van de onbenutte capaciteit c.q. verhoging van de efficiëntie aan de aanbodzijde de hiermee gepaard gaande besparing in de directe kosten gelijk is aan de indirecte tijdkosten voor de klant. Onder dergelijke omstandigheden zullen er relatief duurdere diensten worden aangeboden aan klanten die niet veel tijd wensen te spenderen en relatief goedkopere diensten aan klanten die bereid zijn hiervoor relatief meer tijd te spenderen. Tevens kan gesteld worden dat relatief dure diensten kunnen worden aangeboden op momenten waarop de tijdprijs van de klant lager ligt (avond, weekend).

De aanwezigheid van het marktmechanisme zal tot een afstemming leiden van het aanbod op de gewenste dienstverlening. Bij het ontbreken van een dergelijk marktmechanisme bijvoorbeeld omdat de prijzen vastliggen zullen de aanbieders ernaar streven om leegloop van capaciteit tot het uiterste te reduceren. Dit laatste zal gepaard gaan met relatief lange wachttijden. Het voorgaande maakt eveneens duidelijk dat indien de opbrengsten voor een bepaalde periode vastliggen en onafhankelijk zijn van het niveau van de dienstverlening de aanbieders wachttijden kunnen gebruiken om het niveau van de vraag te reduceren en daarmee hun winst of inkomen te vergroten en/of hun inspanning te verlagen.

Uit het bovenstaande blijkt dat het gedrag van de aanbieders ten aanzien van de tijdinputs van de consument in belangrijke mate bepaald wordt door de marktomstandigheden waarbinnen deze aanbieders opereren. Indien tijdinputs van de consument belangrijk worden geacht is met name het afspraaksysteem een instrument om de wachttijden van de klanten te beïnvloeden. Kirkels en De Vries (1980) stellen dat er in Nederland bij het instellingsmanagement opmerkelijk weinig informatie beschikbaar is over de gehanteerde afspraaksystemen in de diverse poliklinieken. In het betreffende artikel laat men zien op welke wijze met behulp van simulatiemodellen de wachttijden van de klant geminimaliseerd kunnen worden, gegeven de voorwaarden die men stelt ten aanzien van een acceptabele leegloop van de capaciteit. Voor het toepas. sen van dergelijke modellen is uiteraard wel informatie nodig ten aanzien van variabelen zoals de gemiddelde consultduur, het gemiddeld te vroeg of te laat komen van de patient en de spreiding in dergelijke variabelen.

Naast het hanteren van een accuraat afspraaksysteem zijn ook het tijdstip van de dag c.q. de dagen in de week waarop patiënten terecht kunnen een factor waarmee de 
kasten van de tijdinputs wan de patiënt gereduceerd kunnen worden. Zo kunnen spreekuren na kantoortijd of op zaterdag woor de patiënten aantrekkelijker zijn vanwege lagere alternatieve kosten. Het is opmerkelijk dat de dreiging van commerciële poliklinieken in 1987 voor een aantal ziekenhuizen aanleiding was om de tijdstippen wan de spreekuren meer af te stemmen op de voorkeuren wan hun klanten.

\subsection{SAMENVATTING}

In dit hoofdstuk is op basis van diverse bronnen benaderd welke omvang de indirecte kosten als gevolg van tijdinputs van consumenten hebben en in welke verhouding deze staan tot de directe kosten. Op basis van tijdbestedingsonderzoek is berekend dat in 1981 de indirecte kosten 13,5\% wan de directe kosten van ambulante zorg bedroegen. Voor de eerder in deze studie onderzochte consumptiecategorieën varieerden deze percentages van $10 \%$ tot $16 \%$. Vervolgens is met behulp van de in deze studie geschatte ellasticiteiten de gevoeligheid van de directe kosten onderzocht voor veranderingen in tijdprijzen. Als gevolg van een denkbeeldige tijdprijsverandering van $10 \%$ bleken de direkte kosten tussen de 0 en $3 \%$ toe te nemen. De totale kosten stijgen met $0,3 \%$ a $2,2 \%$. De hier gepresenteerde resultaten dienen met terughoudendheid geinterpreteerd te worden, omdat er diverse niet te toetsen aannames zijn gemaakt en het gebruikte cijfermateriaal met statistische onzekerheid behept is. In paragraaf 8.5. is er een overzicht gegeven van de mogelijke implicaties van deze studie voor het belleid. Tijdprijzen leiden tot uiteenlopende effecten van de invoering van eigen bijdragen. Daarnaast leidt ook de hantering van uniforme planningsnormen tot ongelijke toegankelijkheid alls gevolg van tijdprijseffecten. Aannemend dat tijdinputs voor een substantieel deel particulier gefinancierd worden leiden zij tot een andere verdeling van de totale kosten over collectieve en particuliere middelen dan wanneer in deze verdeling alleen de directe monetaire kosten betrokken worden.

Tot slot is aangegeven op welke wijze marktomstandigheden het gedrag van aanbieders met betrekking tot tijdinputs van klanten kunnen beïnvloeden. Met behulp van simulatiemodellen, ontwikkeld binnen de operational research (zie voor een overzicht, Boldy en Kane, 1982), kunnen instellingen de wachttijden reduceren onder condities die zij zelf stellen bijvoorbeeld ten aanzien van acceptabele leegloop van capaciteiten. 
Noten

1. Hierbij is aangenomen dat de verdeling van de waarnemingen over de leeftijdsgroep 16-24 jaar identiek is aan de verdeling over de leeftijdsgroep 1224 jaar. Dezelfde aanname is gemaakt voor de leeftijdsgroepen 50-64 jaar en $50^{+}$.

2. De directe kosten per verpleegdag zijn berekend op basis van de totale kosten van de algemene categorale, academische en psychiatrische ziekenhuizen (Ministerie van WVC, 1987) en het totaal aantal verpleegdagen (Centraal Bureau voor de Statistiek, 1984). In deze kosten zijn opgenomen de kosten van poliklinieken dagverpleging en van de in dienstverband werkende specialisten en artsen. 

"Bij een leefijjd van ruwweg $10^{30}$ jaar, maar zeker bij $10^{40}$ jaar, zal het grootste deel van alle materie vervallen zijn en zal het heelal grotendeels bestaan uit elektronen, positronen (positieve elektronen), neutrino's, fotonen en zwarte gaten. De temperaturu van het heelal zal $10^{20}$ Kelvin bedragen, dus een fractie van een fractie van een graad boven het absolute nulpunt. De straal van het heelal zal dan ongeveer $10^{20}$ maal de huidige straal zijn." (Shallis, 1988).

\subsection{INLEIDING}

In deze studie ligt de nadruk op het onderzoek naar de relatie tussen tijdprijzen enerzijds en medische comsumptie en gezondheid anderzijds. De analyses zijn uitgevoerd op gegevens verkregen uit de CBS-Gezondheidsenquete. Deze data zijn verzameld op het niveau van individuen cq. huishoudens en hebben betrekking op de medische consumptie, persoonlijke kenmerken (leeftijd, geslacht, opleiding, werk; inkomen enz), orngevingskenmerken (huishoudsamenstelling, urbanisatiegraad). Uit andere bromnen (zie par. 2.4.) zijn hier gegevens met betrekking tot het aambod van voorzieningen aan toegevoegd. Toetsing van de voorspellingen op basis van de tijdprijstheorie vond plaats met behulp van multiple regressie-technieken. In geval van een niet normale verdeling van de afhankelijke variabele werd deze gedichtomiseerd en werd een logistische specificatie van het model getoetst op basis van de maximumlikelihood schattingstechniek. In de overige gevallen werd gebruik gemaakt van de gewone kleinste kwadraten methode. In deze slotbeschouwing komen de volgende anderwerpen aan de orde: een samenvatting van de schattingstesultaten in paragraaf 9.2. cen samenvatting van de beleidsimplicaties in paragraaf 9.3 , en een bespreking van de beperkingen van deze studie en suggestíes voor verder onderzoek in paragraaf 9.4. 


\subsection{RESULTATEN}

\section{Effecten van tiljd en tijdprijzen op medische consumptie}

In de hoofdstukken $3,4,5$ en 6 werd achtereenwolgens onderzocht of en in welke mate er sprake is van effecten van tijdbesteding en tijdprijzen op diverse vormen van medische consumptie. De onderscheiden consumptiecategorieën hadden achtereenvolgens betrekking op huisartsenhulp, medicijnengebruik, poliklinische specialistische zorg en klinische zorg. Bij de specificatie van de vraagmodellen is er zoveel mogelijk onderscheid gemaakt tussen consumptie, die door een cliènt respectiewelijk de hulpwerlener geinitieerd werd. De onderliggende veronderstelling bij dit onderscheid was dat het effect van de tijdprijsvariabele geringer zal zijn naarmate de cliënt minder invloed heeft op de beslissing tot consumptie. Anderzijds is dit onderscheid van belang voor de specificatie van het verklaringsmodel. Immers een eventueel aanbodeffect op de medische consumptie kan slechts dan aan de orde zijn indien de hulpverleners in de mogellijkheid verkeren de beslissing tot al of niet gebruik van voorzieningen mede te beïnvloeden. In de modellen waarin consumptie verklaard wordt die door de cliënt is geïnitieerd zijn derhalve geen aanbodvariabelen opgenomen.

Op deze wijze zijn er 8 consumptiecategorieën onderscheiden. Van al deze 8 modellen zijn er een tweetal basisvarianten geschat. Bij de eerste variant, aangeduid als een A of B-model werd de benodigde tijd gekoppeld aan de aard van de tijdbesteding van de betreffende persoon. Hierbij werden de volgende 6 tijdbestedingsgroepen onderscheiden:

1. Individuen die momenteel minstens 40 uur per week werkzaam zijn als loonof salaristrekkend (full-time loontrekkers).

2. Individuen die minstens 40 uur per week werkzaam zijn als directeur, medewerkende in gezins- of familiebedrijf, zellfstandig werkend voor eigen rekening of op freelance basis (directeuren en zelfstandigen).

3. Individuen die geen betaalde werkkring hebben en die volledig werkzaam zijn in eigen huishouding, waarbij in de betreffende huishouding minstens éen kind aanwezig is (huisvrouwen met kind).

4. Individuen die een dagopleiding volgen (scholieren en studenten).

5. Individuen die een WAO-, AWW, werkloosheids-, bijstandsuitkering genieten of een combinatie hiervan, en geen betaald werk verrichten (niet-actieven).

6. Individuen die niet tot een van de hiervoor genoemde groepen behoren. Dit zijn voornamelijk individuen met een part-time diemstverband of individuen die werkzaam zijn in een huishouden zonder kinderen (restgroep).

Op basis van criteria zoals genoemd in par. 2.4. werden er tussen een aantal groepen ordinale verschillen in tijdswaardering verwacht. In de A-variant werd getoetst of er sprake was van een verschil in effect van de benodigde tijd voor medische consumptie voor de diverse tijdbestedingsgroepen ten opzichte van een referentiegroep. Deze referentiegroep bestond in alle gevallen uit personen, die minstens 40 uur werkzaam zijn als directeur, medewerker in gezins- of familliebedrijf, zelfstandig werken voor eigen rekening of op freelance basis (groep 2). In de B-variant werd getoetst of de benodigde tijd een significant van nul verschillend effect op medische consumptie heeft. De $\mathrm{A} / \mathrm{B}$ varianten werden geschat op gegevens die als representatief beschouwd kunnen worden voor de niet-geïstitutionaliseerde Nederlandse bevolking van $16 \mathrm{t} / \mathrm{m} 64$ jaar. De 
tweede basisvariant, de C-variant werd geschat op dat deel van de hierboven genoemde populatie dat een inkomen uit arbeid verdient en waarvan dit inkomen bekend was. $O$ p basis van het aantal uren dat men per week werkte en het inkomen per week werd er een schaduwprijs voor tijd berekend. Op basis van deze schaduwprijs is vervolgens de benodigde tijd voor medische consumptie gewaardeerd. De op deze wijze gewaardeerde benodigde tijd is de zogenaamde tijdprijs.

In tabel 9.1. wordt een overzicht gegeven van de samenhangen zoals die op basis van de $\mathrm{A} / \mathrm{B}$ varianten van de modellen I $/ \mathrm{m}$ VIII werden getoetst. Uit dit overzicht blijkt

Tabel 9.1. Overzicht van effect van tijdsbestedling op medlsche consumptle

\begin{tabular}{|c|c|c|c|c|c|c|c|c|c|c|c|}
\hline \multirow{3}{*}{$\begin{array}{l}\text { Tijobestedings- } \\
\text { graepen: }\end{array}$} & \multicolumn{6}{|c|}{ Model varianten: } & \multirow{2}{*}{\multicolumn{2}{|c|}{$\vdots$}} & \multirow{3}{*}{$\frac{V I}{A}$} & \multirow[b]{2}{*}{ VII } & \multirow{3}{*}{$\frac{\text { VIYI }}{A \quad A}$} \\
\hline & \multicolumn{2}{|c|}{$I$} & $\mathbb{I I}$ & \multicolumn{2}{|c|}{ III } & IN & & & & & \\
\hline & A & $B$ & A B & A & $\mathrm{B}$ & A B & A & B. & & B & \\
\hline (1) Full-time loontrekkers & +4 & & & & - & + & & & & - & H \\
\hline $\begin{array}{l}\text { (2) Full-time directeuren } \\
\text { en zelfistandigen }\end{array}$ & - & - & & - & - & & & & - & - & \\
\hline (3) Huishouden met kind & & - & & + & - & ++ & & & +4 & & ++ \\
\hline (4) Scholieren en studenten & & - & & & - & & & & + & & \\
\hline (5) Niet-actieven & & - & & & $-\infty$ & & & & + & & ++ \\
\hline (6) Restgroep & ++ & & & & - & + & & & & & ++ \\
\hline
\end{tabular}

1) + of - betekent dat de samenhang significant positief resp. negatief van nul verschilt bij $0 \leq p \leq 0,05$;

+ of - betekent dat de samenhang significant pasitief resp. negatief van null verschilt bij $0,05 \leq p \leq 0,10$;

Afwezigheid van genoemde symbolen duidt erop dat er geen samenhang is vastgesteld waarbij $p \leq 0,10$.

2) Betreffende tijdbestedingsgroep is de referentiegroep

dat voorzover er sprake is van statistisch significante samenhangen deze in het algemeen het verwachte teken hebben. Deze verwachtingen hielden in dat in de A-varianten van de modellen $1 \mathrm{t} / \mathrm{m}$ VI er een negatief effect van de benodigde tijd voor de referentiegroep voorspeld werd en dat de benodigde tijd van de overige tijdbestedingsgroepen een positief hiervan verschillend effect zouden hebben. In de Bvarianten van de modellen I $t / \mathrm{m}$ VI werd voor alle tijdbestedingsgroepen een negatief effect van de benodigde tijd voorspeld. Voorzover er sprake is van significante samenhangen in deze $\mathbb{B}$-varianten hebben deze inderdaad het verwachte negatieve teken.

Tevens werd voorspeld dat bij de consumptiecategorieèn, waarbij het initiatief niet eenduidig alleen door de cliënt genomen wordt het effect van de benodigde tijd geringer of afwezig zou zijn. Deze verwachting wordt bevestigd door de schattingsresultaten van model II, IV, V en VI. De benodigde tijd voor een huisartsenbezoek heeft 
voor geen van de tijdbestedingsgroepen effect op de kans op minstens cen herhalingsconsult. Dit is tevens het geval voor de kans op een eerste specialistenconsult. Bij de kans op een herhalingsconsult bij de specialist is er sprake van een negatief effect voor de tijdbestedingsgroepen 1 en 2 .

De effecten van de modellen VII A en VIII A geven niet een effect van de benodigde tijd weer, marar het effect van het behoren tot een bepaalde tijdbestedingsgroep ten opzichte van de referentiegroep. Hieruit blijkt dat de tijdbestedingsgroepen $1,3,5$ en 6 een hogere kans op een ziekenhuisopname hebben dan de referentiegroep. Ten aanzien van de ligduur worden er geen sïgnificante verschillen vastgesteld. Bij dit laatste resultaat dient opgemerkt te worden dat de schattingspopulatie niet als representatief beschouwd kan worden voor de jaarlijks opgenomen populatie en dat door het relatief gering aantal waarnemingen en de geringe verklarende betekenis van dit model de resultaten met terughoudendheid geinterpreteerd dienen te worden.

In tabel 9.2. zijn de samenhangen opgenomen zoalls die op basis van de schattingen van de modellen I $\mathrm{C} t / \mathrm{m}$ VIII $\mathrm{C}$ werden gevonden. Hel gaat hierbij om tijdprijseffecten op medische consumptie. Met uitzondering wan model $V \mathrm{C}$ hebben de geschatte samenhangen het verwachte negatieve teken: hoe hoger de tijdprijs des te geringer de kans op medische consumptie.

Tabel 9.2. Overzlicht van effecten van tildpri|zen op medlsche consumptie ${ }^{1)}$

Modiel varianten

\begin{tabular}{|c|c|c|c|c|c|c|c|}
\hline & $\mathbb{1 c}$ & II $C$ & $111 \mathrm{C}$ & IV C & $V C$ & VIC & VIII C \\
\hline Tijdprijs & - & & - & & + & & - \\
\hline
\end{tabular}

1)

zie voetnoot 1) bij tabel 9.1 .

Het onverwachte positieve effect dat op basis van model $\mathrm{V} C$ gevonden werd hangt mogelijk samen met de gebrekkige operationalisatie van de tijdvariabele. Immers door hel ontbreken van gegevens over de wacht- en behandeltijd bij een specialistenconsult kan de gebruikte "afstand" als benadering voor reistijd tevens functioneren als een kruisprijs van het substituut klinische zorg.

Op basis van de modellen II $\mathrm{C}$, IV C, VI C en VIII $\mathrm{C}$ wordt er geen significant van nul verschillend effect vasitgesteld van tijdprijzen op respectievelijk de kans op herhalingsconsult bij de huisarts, medicijnen niet op recept, minstens een herhalingsconsult bij de specialist en de ligduur voorwaar men opgenomen is in een ziekenhuis. Het feit dat het verwachte negatieve effect van tijdprijzen op de ligduur (model VIII C) niet bevestigd wordt dient gerelativeerd te worden. Van Vliet (1988) vond cen negatief verband tussen het eerste klas verzekerd zijn en de ligduur. Hij interpreteert dit effect als een tijdprijseffect. De resultaten van de modellen VIII zijin naar alle waarschijnlijkheid beinvloed door het feit dat patiënten die doorverwezen zijn naar een verpleegtehuis of die overleden zijn niet in de gezondheidsenquete zijn opgenomen. 
In hoofdstuk 7 is het model van Grossman getoetst waarbij gezondheid als een investeringsgoed wordt opgevat. Op grond van de herleide vorm van de vraagfunctie naar gezondheid werd een positief effect van de tijdswaardering op gezondheid voorspeld. Er werden aparte modellen geschat voor gezondheid als voorraad en als stroomgrootheid. Het eerste werd geoperationaliseerd middels de eigen perceptie van zijn of haar gezondheidstoestand (model IX). Gezondheid als stroomgrootheid werd geoperationaliseerd middels de kans op dagen met belemmering in activiteiten als gevolg van ziekte (model $\mathrm{X}$ ) en voorwaar er van dergelijke dagen sprake was, het aantal dagen in een periode van 14 dagen (model $X^{\prime}$ ).

Van de genoemde modellen werd een tweetal varianten geschat. In de A-varianten werd getoetst of het behoren tot een bepaalde tijdbestedingsgroep tot een negatieve samenhang met gezondheid leidt ten opzichte van de hiervoor genoemde referentiegroep. Deze modelvarianten zijn geschat op basis van gegevens die representatief zijn voor de niet-geïnstitutionaliseerde Nederlandse bevolking van $16 \mathrm{~V} / \mathrm{m}$ 64 jaar. In de C-varianten van de modellen werd getoetst of de schaduwprijs van tijd benaderd door middel van het inkomen per tijdseenheid een positief effect op gezondheid heeft. Deze $\mathrm{C}$-varianten werden geschat op een deelpopulatie die een inkomen uit arbeid heeft en waarvan dit bekend is.

Uit het overzicht zoals dat in tabel 9.3. gegeven wordt, blijkt dat met uitzondering van tijdbestedingsgroep 4 (studenten en scholieren) individuen die behoren tot de groepen $1,3,5$ en 6 significant minder kans hebben op de beoordeling van de eigen gezondheid als goed (model IX A). Op basis van model X A blijkt eenzelfde patroon wat

Tabel 9.3. Overzlcht van effecten tijdsbesteding op gezondheld)

Model:

tijdbestedingsgroep: $\quad$ IXA $\quad X A \quad X A^{\prime}$

(1) Full-time loantrekkers -

(3) Huishouden met kind -

44) Scholieren en studenten

(5) Niet-actieven

(6) Res tgroep

1 zle voetnoot (1) bij tabel 9.1 . 
betreft de kans op geen dagen met belemmering in activiteiten. Uit de resultaten van model X A', dat geschat is op de deelpopulatie met minstens tén dag met belemmering in activiteiten blijkt, dat alleen tijdbestedingsgroep 5 significant minder dagen zonder belemmering in activiteiten heeft. Deze samenhang lijkt gezien de samenstelling van de betreffende tijdbestedingsgroep mede veroorzaakt worden door een omgekeerde causaliteit.

\section{Tabel 2.4. Overzicht ven effecten van tljdewardering op gezondheld ${ }^{1}$}

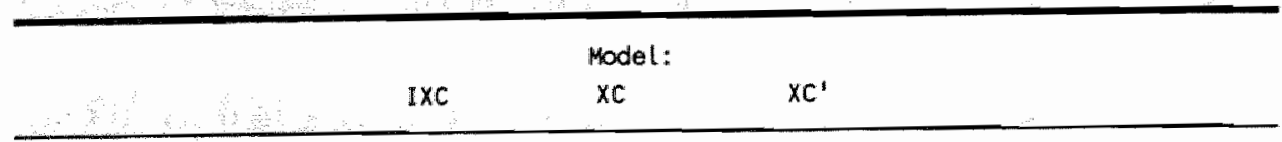

tijoswaarderting

In tabel 9.4. staan de resultaten van de $\mathrm{C}$-varianten weergegeven, die op basis van gegevens van de deelpopulatie met een inkomen uit arbeid toetsen of de hoogte van tijdswaardering van invloed is op de gevraagde voorraad- oq. stroomgezondheid. Deze tijdswaardering is benaderd door het inkomen per tijdseenheid. Uit het gepresenteerde overzicht in tabel 9.4 blijkt dat het verwachte positieve verband dat op basis van het investeringsmodel voorspeld werd, niet bevestigd wordt. Op basis van de resultaten van model IX C wordt een significante negatieve relatie gevonden hetgeen in de richting van het consumptiemodel of de zogenaamde "joint production hypothese" wijst (zie par. 7.4.).

\section{Macro-economische kosten-effecten van tijdprijzen}

In hoofdstuk 8 is benaderd wat de omvang is van de indirecte kosten veroorzaakt door tijdprijzen en de gevoeligheid van de directe kosten voor veranderingen in de indirecte

\section{Tabel 9.5. Indirrecte kosten van gezondheidazorg (1981)}

\begin{tabular}{lll}
\hline & $\begin{array}{l}\text { Ambulante medische } \\
\text { zorg }\end{array}$ & $\begin{array}{l}\text { Klinische zorg in } \\
\text { ziekenhisis }\end{array}$ \\
\hline $\begin{array}{l}\text { Indirecte kosten } \\
\begin{array}{l}\text { kan directe } \\
\text { kosten }\end{array}\end{array}$ & $1.202 \mathrm{mln}$. & $687 \mathrm{mln}$. \\
\hline
\end{tabular}

1) Indirecte kosten zijn berekend woor medische consumptie in de leeftijdsgroep van $16 \mathrm{t} / \mathrm{m} 64$ jaar.

2) Directe kasten hebben betreklking op de totale kosten van ambulante medische zorg.

3) Directe kosten hebben betrekking op de kosten die toegerekend worden aan de leeftijdsgroep waarop de indirecte kosten betrekking hebben. 
kosten. Op basis van diverse bronnen is berekend hoeveel de indirecte kosten wan ambulante en klinische medische zorg bedragen. In tabel 9.5 . staan de uitkomsten weergegeven. Hieruit blijkt dat de indirecte kosten van de ambulante zorg $1.202 \mathrm{mln}$. gulden bedragen op jaarbasis (1981). Dit komt overeen met $13,5 \%$ van de totale directe kosten van deze voorzieningen. De indirecte kosten van de klinische zorg bedragen 687 mln. gulden op jaarbasis in 1981. Dit komt overeen met $15 \%$ van de directe kosten van zorg die aan de leeftijdsgroep van $16 \mathrm{t} / \mathrm{m} 64$ jarigen verleend wordt.

Tewens is in hoofdstuk 8 de gewoeligheid van een drietal consumptiecategorieèn voor veranderingen in tijdprijzen berekend. In tabel 9.6 staan de procentuele effecten van een verlaging van de tijdprijzen met $10 \%$ weergegeven. Hieruit blijkt dat als gevolg van

Tabel 9.6. Procentuele effecten van een afname van de tijdprijzen met 10\%

\begin{tabular}{llll}
\hline & $\begin{array}{l}\text { directe } \\
\text { kasten }\end{array}$ & $\begin{array}{l}\text { Indirecte } \\
\text { kosten }\end{array}$ & $\begin{array}{l}\text { totale } \\
\text { kasten }\end{array}$ \\
\hline Hivisartsenhulp & $+0,9$ & $-3,5$ & 0,3 \\
Farmaceutische thulp & $+2,9$ & $-3,5$ & 2,2 \\
Ziekenhuisopname & $+2,8$ & $-3,5$ & 2,0 \\
\hline
\end{tabular}

11. Aangenomen is dat effecten al leen optreden bi) personen met een eigen inkomen uit arbeid.

een afname van de tijdprijzen met $10 \%$, de directe kosten van huisartsenhulp met $0,9 \%$ toenemen, die van farmaceutische hulp met $2,9 \%$ stijgen en de directe kosten van ziekenhuisopnamen eveneens stijgen met $2,8 \%$. Aannemende dat de indirecte kosten voor alle drie consumptiecategorieën met $3,5 \%$ afnemen leidt dit tot een toename van de totale kosten met respectievelijk $0,3 \%, 2,2 \%$ en $2,0 \%$. Er werd geconcludeerd dat de relatief grote procentuele afname van de indirecte kosten in absolute termen overtroffen wordt door de rellatief geringere procentuele toename van de directe kosten. Als gevolg hiervan nemen de totale kosten toe.

\subsection{BELEIDSIMPLICATIES}

In paragraaf 8.5 worden er een aantal beleidimplicaties besproken van het feit dat ten aanzien van tijaprijzen significante elasticiteiten worden gevonden. Deze hadden betrekking op de volgen de aspecten:

Een verandering in de "out of pocket" prijzen van voorzieningen, bijvoorbeeld de introductie van eigen bijdragen, zal een differentieel effect hebben. Voor personen met relatief lage tijdprijzen zal de totale prijs relatief meer stijgen. Indien voorzieningen waarvoor tot nu toe "out of pocket" prijzen gelden (gedeeltelijk) collectief gefinancierd gaan worden, zal voor personen met relatief lage tijdprijzen de totale prijs relatief mear afnemen. Kortom het onderkennen van tijdprijseffecten is van belang bij beleid dat gericht is op beinvloeding van de verdeling van medische consumptic en gezondheid. 
Regionale spreiding oq. de locatie en bereikbaarheid van voorzieningen is een belangrijke determinant van de afstand $\mathrm{cq}$. de reistijd. De overheid heeft met haar wettelijke planningsbevoegdheden een belangrijk instrument in handen om de reistijd te beinvloeden. Hierbil is een afweging tussen optimale bedrijfsomvang en acceptabele verschillen in reistijd op zijn plaats. Mobiele vormen wan voorzieningen kunnen het scala van alternatieve oplossingen hierbü vergroten, evenals het aanbieden van vervoersfaciliteiten voor de consument (gratis openbaar vervoer bij vertoning verwijskaart).

Verdeling van de kosten van gezondheidszorg over collectieve en private fondsen. Nu het beleid gericht is op een verlaging wan de collectieve bijdrage aan de financièle kosten en als gevolg daarvan de bijdrage vanuit private fondsen toeneemt is het wan belang om de verdeling van de totale maatschappelijke kosten hierbij te betrekken. De indirecte kosten worden immers voor een bellangrijk gedeelte uit private fondsen gefinancierd of uit collectieve fondsen die niet gerekend worden tot de financiering van de directe financiële kosten van gezondheidszorg. Inzicht in de verdeling van de financiering van de totale maatschappelijke kosten van gezondheidszorg over de diverse fondsen is van belang bij de afweging op politiek niveau inzake de wijze waarop de financiering van de directe financiẻle kosten verdeeld zouden moeten worden.

- Instellingen (incl. individuele praktijken) kunnen middels afspraaksystemen de wachttijden beinvloeden. Bij de reductie van wachttijden voor de klant komt een punt waarbij de kans op onbenutte capaciteit toeneemt en daarmee de directe kosten van de hulpverlening toenemen. Daarnaast leidt elke verfijning van het afsprakensysteem tot een toename van de beheerskosten. Vanuit een welvaartstheoretische standpunt zou de inrichting van het afsprakensysteem gericht moeten zijn op minimalisatie van de maatschappelijke kosten. In een markt met volledige mededinging waarbij de aanbodzijde zijn produkt afstemt op de voorkeuren wan de klant gebeurt dit automatisch. Bij afwezigheid van concurrentièle marktverhoudingen zouden normeringen op dit terrein, bijvoorbeeld ten aanzien van gemiddelde wachttijden, in de kwaliteitswetgeving kunnen worden overwogen.

Naar aanleiding van de bevindingen in hoofdstuk 7 , waarin de relatie tussen enerzijds tijdsbestedingen en -waardering en anderzijds de vraag naar gezondheidszorg werd onderzocht kunnen de volgende beleidsimplicaties worden genoemd:

Een beleid dat gericht is op een gelijke verdeling van gezondheid kan zich niet beperken tot het aanbod van voorzieningen en dient mede rekening te houden met individuele verschillen in waardering van gezondheid, die samenhangen met tijdsbesteding en -waardering (Le Grand, 1985; Mooney, 1983).

De gevonden samenthangen kunmen een basis vormen voor beleid dat gericht is op verkleining van verschillen in gezondheid tussen verschillende groepen. De bepaling van prioriteiten ten aanzien van doelgroepen zou mede kunnen plaatsvinden op basis van de grootte van de geconstateerde verschillen. 


\subsection{BEPERKINGEN EN SUGGESTIES VOOR VERDLR ONDERZOEK}

Ondanks het feit dat de analyses in deze studie gebaseerd zijn op een representatieve steekproef van de Nederlandse bevolking, dient men voorzichtig te zijn met generalisaties van de in deze studie gepresenteerde bevindingen. Mede omdat hier sprake is van een zogenaamde secundaire analyse van gegevens die niet specifiek voor dit onderzoek verzameld zijn, zijn we in sommige gevallen gedwongen geweest om te volstaan met een ruwe benadering. Zo ontbraken bij het gebruik van medicijnen op recept gegevens over de tijd nodig om het betreffende recept af te halen. Bij poliklinische specialistische hulp ontbraken gegevens over de feitelijk benodigde tijd. Hierbij moest volstaan worden met de afstand benaderd met behulp van postcodes. Dit gold tevens bij het gebruik van klinische hulp. Het zal duidelijk zijn dat meting van de benodigde tijd voor het gebruik maken van diverse voorzieningen aanmerkelijk verbeterd kan worden.

Vervolgens is de wijze waarop de waardering van de benodigde tijd plaatsvond voor verbetering vatbaar. In deze studie heeft deze plaatsgevonden op basis van het inkomen per tijdseenheid en op basis van de aard van beroepsmatige tijdsbesteding. Dit zijn objectieve variabelen, die geen recht doen aan de individuele subjectieve waardering van alternatieve vormen van tijdsbesteding (zie ook par. 1.3.). Een verbetering in de bepaling van de individuele tijdswaardering zou gerealiseerd kunnen worden indien individuen in een experimentele situatie voor een denkbeeldige keuze worden gesteld. De beperking van deze laatste manier is echter dat het gaat om intentioneel gedrag dat niet hoeft overeen te stemmen met feitelijk gedrag (Fishbein en Ajzen, 1975). Men kan immers moeilijk bijvoorbeeld een beenbreuk simuleren en realisering ervan in een experimentele situatie zou ongetwijfeld tot een selectie-bias leiden, indien dergelijke risico's bij de keuze om al of niet aan een dergelijk experiment deel te nemen van te voren bekend zijn. Optimaal zijn data, die verkregen zijn op basis van feitelijk gedrag, waarbij alle relevante variabelen gemeten kunnen worden. Wat betreft de representativiteit van de data is op te merken dat met name de gegevens over klinische consumptie vertekend zijn door het ontbreken van gegevens van personen die in het ziekenhuis sterven of doorverwezen worden. Tot zover enige opmerkingen over de beperkingen van de gehanteerde data.

Ten aanzien van de modellen, waarin het effect van tijdprijzen op medische consumptie onderzocht wordt, zouden de volgende verfijningen in toekomstig onderzoek aangebracht kunnen worden. Ten eerste zouden in de modellen de reis-, wacht- en behandeltijden apart opgenomen kunnen worden, Dit op basis van empirische bevindingen waaruit blijkt dat deze verschillende vormen van tijdsbesteding anders gewaardeerd worden. Ten tweede zou naast het onderscheid in wie het initiatief tot het gebruik van voorziening nam aparte vraagfuncties geschat kunnen worden op basis van type klachten (diagnose). Dit latste onderscheid lijkt relevant omdat de keuzeruimte cq. de aanwezigheid van substituten aanmerkelijk kan varieren navenant de aard van de klacht.

Ten aanzien van het empirisch onderzoek naar de vraag naar gezondheid stelt Wagstaff (1986a) dat dit feitelijk nog in haar kinderschoenen staat. Essentieel hierbij is dat in het empirisch onderzoek gezondheid gemeten wordt in ongewaardeerde maatstaven. Dat wil zeggen dat men wel een indicatie van de psycho-biologische gezondheidstoestand heeft, echter niet van de financiele waardering hiervoor. Dit laatste is van cruciaal 
belang om de kracht van de economische benadering ten aanzien van dit vraagstuk volledig tot zijn recht te laten komen.

Daarnaast is het van belang om de ontwikkeling van inzichten op specifieke terreinen van de economische theorie, bijvoorbeeld ten aanzien van produktiefuncties, te vertalen naar economische modellen op het terrein van de vraag naar gezondheid. Beschikbaarheid van ruimte en middelen voor fundamenteel onderzoek op dit terrein zijn hiervoor een voorwaarde. 


\section{The effects of time-prices on medical care utilization and health}

The first and major purpose of this study is to examine the determinants of utilization of medical services with special emphasis on the role of time-prices. The second objective is to examine the relation between time-prices and health. In Chapter 1 the theoretical framework is introduced, starting with the home production theory of Becker. In this approach home goods (commodities) are produced using market inputs and time inputs (i.e. work at home). The maximization of welfare is - similar to conventional micro-economics - subjected to two constraints: money income and time. The time constraint specifies that time is a scarce resource to be allocated among its two alternative uses: work in the market and work at home. The latter includes time used for consumption. One of the two constraints can be removed because time can be converted into goods by using less time at consumption and more at work.

Next a review is presented of applications of the home production theory on the demand for medical services. First Acton's (1973) formal model is presented. It is a utility maximization model that allows people to "pay' with money and time for medical services and other goods. The model predicts - among other things - that time functions as a price for consumers. It also predicts that the time-price elasticity of demand for medical services will exceed the money-price elasticity as out-of-pocket money prices become smaller. This implies that changes in time-prices will have a greater effect on the demand for free medical services than on the demand for non-free services.

Similar models are used by Phelphs and Newhouse (1974), Holtman (1972), Coffey (1983) and Leibowitz (1984). A survey of the results of these studies is presented in Chapter 1. After these models of the demand for medical services a model of the demand for health is presented. This 'demand for health' approach was developed by Grossman (1972a, 1972b) and is also based on the home-production theory. There are three main differences with the former approach of Acton. Firstly, not medical services but health is assumed to be a desirable good and is therefore an element of the objective function. Secondly, health is treated not only as a consumption good but also as an investment good. Health is considered as for example education as a human capital stock. A third difference is that the demand for medical services is derived from the desired level of health stock. In this approach time functions not only as an input of the production function of health but also as an output. Because better health implies more healthy time and therefore more capacity to earn income. So under certain conditions the 'demand for health' approach predicts positive effects of higher time-prices on the demand for medical services in contrast to the 'demand for medical serwices' approach.

In this study we have chosen for the latter approach to determine the effect of timeprices on the demand for medical services. The main reason for this is the lack of data to estimate a reasonable health production function, which is in the 'demand for health' approach necessary to determine the effects on time-prices on the demand for medical 
services. Based on Acton's model of the demand for medical services empirical models are estimated on the demand for:

- general practitioner services

- prescribed and non-prescribed medicine

- physician services in an out-patient department

- clinical hospital services

The results are presented in the Chapters 3 to 6 . Furthermore, some empirical models are estimated to test for an effect of time-prices on health based on the 'demand for health" approach. These models are identified by the reduced form equation for the demand for health. So the lack of appropriate data could be circumvented. The results are presented in Chapter 7.

The data used came from a continuous Health Interview Survey of the Netherlands Central Bureau of Statistics (CBS). Each year a random sample of households is drawn from the general Dutch population excluding institutionalized persons. In principle all residents at the selected addresses are interviewed. The size of the response group amounts to about 10,000 persons a year. The analyses in this study are based on the data of persons between the age of 16-64. This reduced the total size of the sample to about 6,000 adult individuals.

In the models on the demand for medical services a distinction has been made as far as possible between consumption which is initiated by the patient and by the supplyside. In general the value of time is approximated by the opportunity cost of time, i.e. the hourly wage. Because for a large part of the sample the hourly wage is not known or they do not earn any income, this approach is not entirely satisfactory. Therefore also another way is used to value the time requirements. A series of time requirement interaction variables was created so that separate estimates of the elasticities of demand with respect to time requirement could be obtained. Six categories were created based on the individual's employment status. Individuals who did not fall into a category were assigned a value of zero for the corresponding interaction variable. The following six categories of employment status were distinguished:

1. full-time wage-earners

2. full-time managers, directors, and self-employed

3. housewives with at least one chilld

4. students

5. people who receive a payment or an unemployment benefit

6. remaining category

It is assumed that people who belong to the second category have a relatively high value of time requirement. On this basis it was predicted that the time requirement interaction variable for the other categories will have a positive parameter. The estimated partial relationship between the time requirement and the demand for care is the sum of the parameter of the common time requirement variable and the parameter of the time requirement interaction variable of a specific category. For example for full-time wage-earners the estimate would be equal to the sum of parameters for the time requirement variable and the full-time wage-earners interaction variable. 
The statistic distribution of the dependent variables does not meet the criteria of normality, since just a small part of the population has used medical services during the period under consideration. So we decided to transform the dependent variable in a dichotomous variable namely the probability of having used medical services or not. We have used the logistic multiple regression model.

In Chapter 3 the estimation results of the model for the demand for general practitioner services are shown. On the whole the predictions are confirmed. In general time requirements significantly influence the probability of the use of GP services initiated by the patient. Only for the category of wage-earners and the remaining category no significant effects were found. In addition there were significant effects of time-prices on the probability of the use of GP services in the cases the hour-wage was known. The effects of time requirements and time-prices in all cases had the predicted negative sign. The elasticities of demand with respect to time requirements varied from -0.21 to -0.50 . The elasticity of demand with respect to time-prices amounted to -0.34 . No significant effects were found neither for time requirements nor for time-prices on the probability on the use of GP services which was not initiated by the patient but by the GP or a colleague.

In Chapter 4 models are estimated for the probability of having used prescribed and non-prescribed medicines. It was assumed that the time required for consulting a GP acts as a time-price for prescribed medicine and as a cross time-price for medicine without a prescription. In the former case a negative effect was predicted, in the latter a positive one. For all employment categories significant negative effects were found of time requirement on the probability of using prescribed medicine. Time-prices were shown to have the same effect for the category with an earned income. The elasticities of demand with respect to time requirements varied from -0.41 to -0.88 . The elasticity of demand with respect to time-prices amounted to -1.09 . Although we found significant effects of some of the interactive time-price variables on the probability of using medicine without prescription, for none of the employment categories the results confirmed a significant cross price effect of the time requirement. Neither we found an effect of time-prices for the category with an earned income. So we had to conclude that time required for a consultation of the GP does not function as a cross-price of medicines which someone can get without a prescription of a physician.

In Chapter 5 the effects are estimated of time requirements on the probability of having a first consultation of a physician respectively having a repeat visit. The former is assumed to be initiated by a GP (only privately insured are in some cases allowed to consult a physician without being referred by a GP), while the latter is usually initiated by the physician. So in the models variables are introduced to account for possible supplier-induced demand. In general no influence was found of time requirements or time-prices on the probability of having a first consultation of a physician in an outpatient department. In contrast to the previous case we now did find an effect of time requirements on the probability of a repeat visit for the respondents who belong to the categories with an employment status of being a full-time wageearner, manager, director or self-employed.

The estimated parameters are likely to be biased towards zero on account of the following circumstances. We did not know the true time required for travelling, waiting and treatment. Only an approximation for the travel-time was available. This was 
determined by the location of the address of the household of the respondent and the location of the next hospital. Further-more we did not really know whether the consultation of the physician did take place in the out-patient department of that hospital. Neither any effect was found of the GP-density on the probability of a first consultation of a physician. More research with more appropriate data is necessary to determine the true effects of time requirements and time-prices on the utilizzation of physicians. Furthermore it is important to mention the significant positive effect of the physician density on the probability of having a repeat visits. The elasticity of utilization with respect to physician density varies from 0.33 to 0.52 .

In Chapter 6 the effects are estimated of the employment status and wage-rates on the probability of hospitalization and on the length of hospital stay. We found a significant effect of belonging to one of the categories with an employment status but the reference category with an exception of those who belonging to the category of students. Persons belonging to those categories have a $35 \%$ to $70 \%$ higher probability to be admitted to a hospital. The elasticity of the probability of a hospitalization with respect to the wage-rate of the category with an earned income amounted to -0.79 . No effects were found of time requirements and hour-wages on the length of hospital stay.

In Chapter 7 the 'demand for health' approach is tested. Different models were estimated with the health as a capital stock and as a capital flow. Health as a capital stock is measured by the self-rated general health status. A positive effect of the wagerate was predicted and a negative effect of belonging to the category with an employment status other than the reference category. The latter prediction was in general confirmed: all employment status categories showed a poorer health status than the reference category with exception of students. But we did not find a positive effect of the wage-rate on health status. On the contrary, a significant negative effect was found. The elasticity of the demand for health with respect to the wage rate amounted $-0,04$. The chance to have a health status rated as 'good' was about $3 \%$ lower for the categories with the employment status $1 \%, 3 \%$ and $6 \%$, and $18 \%$ lower for the category with the employment status 4 . Health as a capital flow was first measured by the probability to have no day with restricted activities (DRA) during a period of 14 days and for the subsample that had one DRA the negative log of the number of DRA's was estimated. We found that persons belonging to the categories with an employment status 1,3,5 and 6 had significant lower chances on having no DRA than the reference category. These chances were $6 \%$ lower. Only for the category with the employment status 3 to 5 we found a significant effect on negative log of the number of DRA's. No effect was found of the wage-rate on the chance of having no DRA. Neither an effect was found of the wage-rate on the negative log of the number of DRA's once one had had one DRA. Considering these results we concluded that there is a relation between employment status and the demand for health. The negative effect of the wage-rate on the demand for health is inconsistent with the predictions of Grossman's human capital approach. We concluded that for this subsample the consumption good approach could be more appropriate and that the negative effect of the wage-rate could be caused by the so-called joint production effect. The latter implies that higher wage-rates cause consumption uses with negative effects on health.

In Chapter 8 we presented some calculations of the macro-economic time costs of the health care system and the sensitivity of the total costs of health care with respect to changes in time-prices. First we computed an estimate of the time costs of out-patient 
health care. They amounted to about 1,2 millard Dutch guilders in 1981 . That is about $13 \%$ of the direct money costs of the out-patient health care. Secondly, we estimated the time costs of in-patient care at 87 million Dutch guilders which equals about $15 \%$ of direct money cosis of the clinical health care. Furthermore, we calculated on the basis of the estimated elasticities the sensitivity of the direct money costs with respect to a reduction of the time costs with $10 \%$. The money costs of the utilization of GPs increased about $1 \%$, the costs of consumption of prescribed medicine grew about $3 \%$ and that of hospital care increased about $3 \%$.

The following policy considerations are suggested by the significant elasticities for timeprices in paragraph 8.5 :

- If out-of-pocket monetary expenses increase because of the implementation of for example co-payments, in that case persons with a lower opportunity cost of time will be at a greater disadvantage than those with higher opportunity cost of time. In general a change in monetary prices will be to shift the distribution of medical services.

- Political decisions which aim at a certain distribution of total costs of the health care system between collective and private resources should account for the in general privately financed time costs of utilization of health care.

- Since travel time is a substantial part of the total time costs, decisions about location of GPs and clinics should rest among other factors on these time costs of travelling.

- Improvement of the appointment system enables a reduction in the waiting time and therefore the time costs. In this way the efficiency of the health care system as a whole can be improved.

Finally, some recommendations are made to improve the research for the effects of time-prices on the demand for medical services and for health. First of all the lack of appropriate data about true time requirements should be solved to estimate. Secondly, the valueing of time requirements could be improved by using reported data instead of perceived and engineering values. Finally, we suggested that the specification of the production function of health could be improved in case of the 'demand for health' approach. It is suggested that this improvement could be realized with the application of the well-known vintage approach in macro-economic models. 



\section{LITERATUURLIJST}

Acton, J.P. (1973a), The demand for health care among the urban poor, with speciall emphasis on the role of time, R-1151-OEO/NYC Santa Monica RAND Corporation, New York.

Acton, J.P. (1973b), The demand for health care whem time prices wry more than money prices, R-1189-OEO/NYC Santa Monica RAND Corporation, New York.

Acton, J.P. (1985), Nonmonetary factors in the demand for medical services: some empirical evidente, The Journal of Political Econony, Vol. 83, pp. 595-614.

Amemiya, T. (1981), Qualitative response models: a survey, Journal of Economic Literature, XIX, pp. 1483-1536.

Amemiya, T. (1985), Advanced Econometrics, Basil Btackwell, Oxford.

Appelboom, W. (1982a), Aspekten van gezondheid en ziekte in de bevolking, Maandbericht Gezondheidsstatistiek/CBS, jrg. 1, pp. 5-8.

Appelboom, W. (1982b), De continue gezondheidsenquete: enkele aspekten ter nadere orientatie, Maandbericht Gezondheidsstatistiek/CBS ${ }_{*}$ jrg. 1, nr. 5, pp. 5-9.

Appelboom, W.J.M.J. (1984), Contacten met huisarts en specialist in 1 jaar; GE 1981 en 1982., Maandbericht Gezondheidsstatistiek/CBS, jrg. 3, ar. 10, pp. 5-9.

Auster, R.,1. Leveson and D. Sarachek (1972), The production of health, an exploratory study, The Journal of Human Resources, ar. 4, pp. 411-436.

Baudelaire, $C_{n}(1925)$, Le peintre de la vie moderne, Uit: Oeuvres Completes. Deel 2, Louis Conard, Parijs.

Becker, G.S. (1965), A theory of the allocation of time, The Economic Journal, nr. 75, pp. 493-517.

Berg, J. van den (1983), Proefonderzoek medische consumptie in 1979 en gezondbeidsenquete 1981, Maandbericht Gezondheidsstatistiek/CBS, jrg. 2, nr. 1, pp. 9-12.

Boldy, D.P. and P.C. O'Kane (1982), Health Operational Research, A selective overview, European Journal of Operational Research, 10, pp. 1-9.

Bosworth, D.L. (1976), Production functions; a theoretical and empirical study, Saxon House, Westmead.

Brekel, EJ.G. van (1983), Voorgeschrewen en niet voorgeschreven medicijnen, Maandbericht Gezondheidsstatitiek/CBS, jrg. 2, nr. 12, pp. 5-24.

Brekel, E.J.G. van (1985a), Contacten met specialisten 1981-1983, Maandbericht Gezondheidsstatistiek/CBS, jrg. 3, nr. 12, pp. 5-24.

Brekel, EJ.G. van (1985b), Ziekenhuisopnamen 1981-1983, Maandbericht Gezondheidsstatistiek/CBS, Jrg. 4 nr. 7, pp. 5-25

Brekel, EJ.G. van (1987), Zelfmedicatie, 1981-1985, Maandbericht Gezondheidsstatistiek/CBS, jrg. $\sigma_{x}$ m. 4 , pp. 11-21.

Bruzelius, N. (1979), The walue of travel time, Croom Helm Lid., London.

Büttner, J. (1977), Die Beurteilung des diagnostischen Wertes klinisch-chemischer Untersucinungen, Jourrial of Clim. Chem. Clin. Biochem., vol. 15, nr. 1, pp. 1-12. 
Carrin, $\mathrm{G}$. and $\mathrm{D}$. de Graeve (1986), Patienten en hwn radplegingen van huisartsen en specialisten. Een toepassing van het model van Grossman, Acta Hospitalia, nr. 3, pp. 5-20.

Cauley, S.D. (1987), The time price of medical care, Review of Economics and Statistics, vol. 69, pp. $59-66$.

Centraal Bureau voor de Statistiek (1981), Gezondheidsenquete, Staatsuitgewerij, Den Haag.

Centraal Bureau voor de Statistiek (1982), Statistisch Zakboek, Staatsuitgeverij, Den Haag.

Centraal Bureau voor de Statistiek (1983), Diagnose-statistiek ziekenhuizen, Staatsuitgeverij, Den Haag.

Centraal Bureau voor de Statistiek (1984), Compendium Gezondheidsstatistiek, Staatsuitgeverij, Den Haag.

Centraal Bureau voor de Statistiek (1984), Maandbericht Gezondheidsstatistiek, jrg. 3, nr. 10.

Centraal Bureau voor de Statistiek (1985), Diagnose-statistiek ziekenhuizen 1981-1982, Staatsuitgeverij, Den Hag.

Centraal Bureau voor de Statistiek. (1986), Compendium Gezondheidsstatistiek Nederland 1986, Staatsuitgeverij, Den Haag.

Centraal Bureau voor de Statistiek (1988), Sociaal-economische maandstatistiek, 5, nr. 2.

Central Bureau voor de Statistiek / Mim. van WVC. (1981), Vademecum Gezondheidsstatistiek 1981, Staatsuitgeverij, Den Haag.

Centraal Plan Bureau (1987), Centraal Economisch Plan, Staatsuitgeverij, Den Haag.

Cleary, P.D. and R. Angel (1984), The Analysis of Relationships Involwing Dichotomous Dependent Variables, Journal of Health and Social Behaviour, Vol. 25, nr. 3, pp. 334-348.

Coffey, R.M. (1983), The effect of time price on the demand for medical care services, The Journal of Human Resources, nr. 18, pp. 407-424. Wisconsin.

Commissie voor de Ontwikkeling van Beleidsanalyse (1975), Kosten-baten analyse 2, Beleidsanalyse 75-4, pp. 2-67 Staatsuitgeverij, Den Haag.

Department of Health and Social Security (1985), Reducing wailing time in out-patient departments, DA(85)6 DHSS, Middlesex.

Deserpas, A. (1971), A theory of the economies of time, The Economic Journal, nr. 81, pp. 828-845.

DeVany, A.S. et al. (1983), Production in a service industry using customer inputs: a stochastic model, The Rewiew of Economics and Statistics, nr. 65, pp. 149-153.

Dixon, W.I. et al. (1983), BMDP Statistical Software Manual, Univ. Calif. Press, Berkeley.

Doorslaer ,E.K.A. van (1987), Health, knowledge and the demand for medical care; an econometric analysis, proelschrift, van Gorcum, Maastricht.

Elias, N. (1982), Een essay over tijd, Meulenhoff, Amstendam.

Enthoven, A.C. (1981), The behavior of health care agents: provider behavior, in: J.van der Gaag and M Perlman:Health, economics and health economics, North Holland Publ., Amsterdam.

Feldstein, M. (1974), Econometric studies of health economics, in: M.Intriligator and D. Kendrick (red.), Frontiers of quantitative economics, Vol, 2, North Holland Publ. Comp., Amsterdam.

Feldstein, P.J. (1983), Health care economics, Second edition John Wiley and Sons, New York. 
Fishbein, M. and J. Ajzen (1975), Belief, attitude and behaviour ${ }_{n}$ Addison Wesley, Massachusetis.

Fuchs, V.R. (1978), The supply of surgeons, and the demand for operations, The Journal of Human Resources, nr.13, suppl., pp.35-56.

Geurts, J. en R. Janssen (1987), Meer bedden nodig voor gescheiden mensen, Het Ziekenhuis, ar. 16, pp. $686-687$

Geurts, J.J.M., E.K.A. van Doorsłaer en F.F.H. Rutten (1985), Samenwerkende huisartsen: andere behandeling of andere patienten?, Tijdschrift voor Sociale Gezondheidszorg, nr. 20, pp. 834-841.

Goris, H. (1972), Inleiding in de econonetrie, De Bussy/Oosthoek, Amsterdam/Utrecht.

Grossman, M. (1972a), On the concept of health capital and the demand for health, The Journal of Political Economy, ur. 80, 2, pp. 223-255.

Grossman, M. (1972b), The demand for health: a theoretical and empirical investigation, Columbia Univ. Press, New York.

Hagen,J.H. (1985), Gezondheidszorg en defensieve bestedingen, proefschrift, Amsterdam Foris Publications, Dordrecht.

Heathfield, D.F. and S. Wibe (1987), An Introduction to Cost and Production Functions, MacMillan Educ. Lid., London.

Hofland, J. en P.J.M. Wilms (1984), Onder behandeling: strategische keuzen bij de kostenbeheersing in de gezondheidszorg, Instituut woor onderzoek van overheidsuitgaven, Kluwer, Deventer.

Holtman, A.G. (1972), Prices, time and technology in the medical care market, The Journal of Human Resources, nr. 7, 2, pp. 179-190.

Homan, M.E., A. Hagenaars en B. van Praag (1988), Interhuishoudelijke vergelijking van consumptie, welvaart en tijdsalliocatie, Rapport Erasmus Universiteit, Rotterdam.

Hussen, J.G.M. van (1982), Regionale indelingen en gezondheidsstatistieken, Maandbericht Gezondheidsstatistiek/CBS, jrg. 1, nr. 4, pp. 5-25.

Jessen, J.L. (1974), Medische Consumptie, Rapport over het onderzoek naar medische concumptie van de Nederlanders anno 1970, Sociologisch instituut R.U. Gron. Rijksuniv. Groningen, Groningen.

Kelsey, J.L.W.,Douglas Thompson and A.S. Evans (1986), Methods in Observational Epiderniology, Oxford Univ. Press, New York.

Kemna, H.J.M.I. (1987), Working conditions and the relationship between schooling and health, Journal off Health Economics, vol. 6, nr. 3, pp. 165-281.

Killingsworth, M.R. (1983), Labor supply, Cambridge Uniw. Press, Cambridge,

Kirkels, M. en G. de Vries (1980), Operationele research in ziekenhuizen, Intermediair pp.1-9.

KLOZ informatiesysteem gezondheidszorg (1982), Jaarboek 1981, KISG, Bunnik.

Knulst, W en L. Schoonderwoerd (1983), Waar bllift de tijd:een onderzoek naar de tijdsbesteding wan Nederlanders, Sociaal Cultureel Planburo Staatsuitgeverij, Den Haag.

Kruidenier, HJ. (1977), Afstand tot het ziekenhuis van invloed op verwijspatroon, Inzet, nr. 1, pp. 32-39.

Landelijk Informatie Systeem Ziekenfondsen (1983), Jaarboek LISZ 1982, Ver. wan Ned. Ziekenfondsen, Zeist. 
Le Grand, J. (1985), Inequalities in health and health care, Nuffield/York Portfolio"s. nr. 5. Nuff. Prov. Hosp. Trust, York.

Leibowitit; $\mathrm{A}$ (1984), Measuring the value of time in medical care analyses, N-2127-HHS, Santa Monica RAMD Corporation, New York.

Luft, H.S. (1975), The impact of poor health on earnings, The Review of Economics and Statistics, vol. 57, nr. 1, pp. 43-57.

Mackenbach, J.P. (1987), Sociale ongelijkheid en verschillen in gezondheid; een overzicht van de belangrijkste onderzoeksbevindingen, in: Ministerie wan WVC en de WRR ${ }_{n}$ De ongelijke verdeling van gezondheid, Staatsuitgeverij, Den Haag.

Made, J. wan der en R. Janssen (1989), Privatisering en particulier initiatief in de gezondheidszorg, in: Mierlo, J. wan: Het particulier initiatief in de klem, De Tijdstroom, Lochem.

Manning, W.G., J.P. Newhouse, N. Duan , E.B. Keeler, A. Leibowitz and M.S. Marquis (1987), Health Insurance and the Demand for Medical Care: Evidence from a Randomized Experiment, The American Economic Review, nr. 3, pp. 251-277.

McGuire, A, J. Henderson and G. Mooney (1988), The economics of health care: an introductory text, Routledge and Kegan Paul, London.

Minderhoud, M. (1980), Wachttijden in de polikliniek, Verslag Gezondheidsleer, nr. 1980-89 Landbouw Hogeschool, Wageningen.

Ministerie van Welzijn, Volksgezondheid en Cultuur (1985), Financieel Owerzicht van de Gezondheidszorg en Maatschappelijke Gezondtheidszorg, Tweede kamer 1984-1985, kamerstuk 18600, nr. 9 Staatsuitgeverij, Den Haag.

Ministerie van Welzijn, Volksgezondheid en Cultuur (1987), Financieel Overzicht van de Gezondheidszorg en Maatschappelijke Gezondheidszorg, Tweede Kamer, 1986-1987, kamerstuk 19703, nr.3 Staatsuitgeverij, Den Haag.

Montiort, A.P.W.P. van (1980), Production functions for general hospitals; an econometric analysis, proefschrift, Nat. Ziekenh. Inst., Utrecht.

Mooney, G.H. (1983), Equity in health care; confronting the confusion, Effective Health Care, Vol. 1, nr 4, pp. 179-185.

Mooney, G. and A McGuire (1988), Medical ethics and economics in health care, Oxford Med, Public, New York.

Mutrinen, J.M. (1982), Demand for health, Joumal of Health Economics, nr. 1, pp. 5-28,

Murinen, J.M. and I. Le Grand (1983), The economic analysis of inequalities in health, Brown University and The London School of Economics.

Nationale Ziekenhuisraad, Vereniging van Nederlandse Ziekenfondsen, Landelijke Specialisten Vereniging (1985), Rapport Normenkommissie Ziekenhuispoliklinieken, 4e druk, Utrecht.

Odink, J.G. en J.S. Schoorl (1984), Inleiding tot de micro-economie, Wolters Noordhof, Groningen.

Paully, M.V. (1980), Doctors and Their Workshops; Economic Models of Physician Behavior, Univ. of Chicago Press, Chicago.

Peck, S A and C.D Montgomery (1982), Introduction to linear regression analysis, John Wiley and Sons, New York.

Phelps, C.E. and J.P. Newhouse (1974), Coinsurance, the price of time and the demand for medical services, The Review of Economics and Statistics, vol. 56, pp. 334-342. 
Roemer, M.I. (1961), Bed supply and utilization: a naturall experiment, Hospitals. Joumal of the American Hospitall Association, nr. 35, pp. 35-42.

Rossiter, L.F. and G.R. Wilensky (1983), A Rexamination of the Use of Physician Services: The role of Physician-Imitiated Demand, Inquiry, Vol, 20, pp. 162-172.

Rutten, F.F.H. (1978), The use of health care facilities in the Netherlands. An econometric analysis, proefschrift, Krips Repro, Meppel.

Rutten, F.F.H. en R.T.J.M. Janssen (1987), Een econonische beschouwing over gelijkheid in de gezondheidszorg, in: Ministerie van WVC en de WRR, De ongelijke verdeling van gezondheid. Staatsuitgeverij, Den Haag.

Sackett, D., R. Haynes and P. Tugwell. (1985), Clinical epidemiology, Little Brown and co, Boston.

Samuelson, P.A. (1976), Economics: an introductory analysis, Nieuwe druk in 1980; statistische updating door W. Samuelson. McGraw-Hill, NY, Auckland.

Schaaf, J.H. (1984), Budgettering in ziekenhuizen, Medisch Contact, nr. 2, pp. 41-44.

Schroeff, H.J, van der (1970), Kosten en kostprijs, Deel I Kosmos, Amsierdam.

Shakotko, R.A., L.N. Edwards and M. Grossman (1981), An exploration of the dynamic relationship between health and cognitive development in adolescence, in: J. van der Gaag and M. Perlman; Health, economics and health economics, North Holland Publ, Amsterdam.

Shallis M. (1986), Tijd en kosmologie, in: R. Flood and M. Lockhood. Onomkeerbaarheid van de tijd, Basil Blackwell Ltd. Oxford.

Shannon, C.E. and W. Weaver (1949), The mathematical theory of communication, Univ. of Illinois, Illinois.

Sharp, C. (1981), The economics of time, Martin Robertson Comp., Oxford.

Siegers, J.J. (1985), Arbeidsaanbod en kindertal, Een micro-economische analyse, proefschrift, Enschede.

Sonsbeek, J.L.A. van (1984), Afstand geen bezwaar, Maandbericht Gezondheildstatistiek /CBS, jrg. 3, nr. 3, pp. 5-13.

Sonsbeek, J.LA. van (1986), Consultduur en wachttijd bij een bezoek aan de huisarts, Maandbericht Gezondheidsstatistiek/CBS, jrg. 5, nr. 1, pp. 5*10.

Sonsbeek, J.L.A. en L.H. Stronkhorst (1983), Methodische aspecten van de gezondheidsenquete, in: Statistische onderzoekingen / CBS, Hoofdstuk 5: Herinneringseffekten bij medische contacten, Staatsuitgeverij, Den Haag.

Spangenberg, F. (1979), Wacht- en behandeltijden in de polikliniek, Het Ziekenhuis, 9, nr. 1, p. 14-17.

Stichting Medische Registratie (1982), LMR-jaarboek, SMR, Utrecht.

Stoddart, G.L. and M.L. Barer (1981), Analyses of demand and utilization through episodes of medical service, in: J. van der Gaag and M. Periman; Health, economics and health economics, North Holland Publ., Amsterdam.

Szalai, A., P.E. Converse, P. Feldheim, E.K. Scheuch and P.J. Stone. (1972), The use of time, Mouton + Co., Den Haag.

Townsend, P. and N. Davidson (1982), Inequalities in health, Penguin Books, Middlesex. 
Ven, W.P.M.M. van de e.a. (1980), Inventarisatie en achtergronden van de consumptieverschillen tussen ziekenfonds- en particulier verzekerden, Gezondheid en samenlewing, jig. 1, ar. 4, pp. 224-254.

Ven, W.P.M.M van de (1981), Ziekenfondg- wersus particuliere verzekeringen in de gezondheidszorg, Economisch Stalistische Berichtem, juni, pp. 524-530.

Ven W.P.M.M, van de (1983), Effects of cost-sharing in health care, Health Care 1, nr. 1, PP. 47-58.

Verbrugge, L. (1985), Gender and health: an update on hypotheses and evidence, Journall of Health and Social Behaviour, 26, pp. 156-182.

Vissers, J.M.H. (1977), Wachttijden in đe polikliniek, Het Ziekenhuis, 7, nr. 18, pp. 500-502.

Vissers, J.M.H. (1983), Wachttijden in poliklinieken, Het Ziekenhuis, 13, nr. 3, pp. 72.

Vliet, R.C.J.A. van en E.KA van Doorslaer (1987), Ziekenhuisconsumptie en regionale ziekenhuiscapaciteit, Gezondheid en samenleving, jrg. 8, nr. 2, pp. 77-97.

Vliet, R.C.A.A van (1988), Hospital utilization, performance measures and health status, proefschrift, Rotterdam.

Vhiet, R.C.A van en Wen, W.P.M.M. van de. (1983), Analyse van de verschillen in huisartsenhulp tussen ziekenfonds- en particulier verzekerden, Economisch Statistische Berichten, 68, pp. 456-461.

Vliet, R.C.J.A van, en W.P.P.M. van de Ven (1984), Analyse van medische consumptie en van verschillen tussen ziekenfonds- en particulier verzekerden, III, COEPS-rapport 84.02, SWOKA, Leiden.

Wagstaff, A. (1986b), The demand for health: a simplified Grossman model, Bulletin of Economic Research, Vol. 38, sr. 1, pp. 93-95.

Wagstaff, A. (1986a), The demand for health: some new empirical evidence, The Journal of Health Economics, nr. 5, pp. 195-233.

Wallin, J.O. (1863), Tidens vaerde, in: Samlade Vitterhets-arbeten, suppl. 5, pp. 190. Adolf Bonnier, Stockholm.

Werkgroep Emmen van de Consumentenbond (1984), Wachttijden in de polikliniek van het Scheperstiekenhuis te Emmen, Emmen.

Wilensky, G.R. and L.F. Rossiter (1981), The magnitude and determinants of physician-initiated visits in the United States, in: J. van der Gaag and M. Perlman; Health, economics and health economics, North Holland Publ, Amsterdam.

Wolfson, D.J. (1988), Publieke sector en economische orde, Wolters Noordhoff, Groningen.

Wonnacott, T.H. and R.J. Wonnacott (1981), Regression: a second course in statistics, John Wiley and Sons, New York.

Zee, J. van der (1982), De vraag naar diensten wan de huisarts, proefschrift, Nederlands Huisartsen Instituat, Maastricht.

Ziekenfondsraad (1981), Jaarverslag, Verslag van de Ziekenfondsraad over 1981, Klomp en Bosman, Rotterdam.

Ziekenfondsraad (1983), Jaarverslag, Verslag van de Ziekenfondsraad over het jaar 1983, Klomp en Bosman, Rotterdam. 
Tabel 2.1. Representativiteit met betrekking tot diverse persoonskenmerken van het GE 81-bestand voor de Nederlandse bevolking . .....

Tabel 2.2. Verzekeringsvormen: Nederlandse bevolking versus de Gezondheidsenquête $1981 \ldots \ldots \ldots \ldots \ldots \ldots \ldots$. . . . . . . . . . . .

Tabel 2.3. Overzicht van coefficiënten die het effect van benodigde tijd per tijdbestedingsgroep weergeven $\ldots \ldots \ldots \ldots \ldots \ldots \ldots . \ldots \ldots$

Tabel 2.4. Verwachte effecten van tijd op medische consumptie . . . . 36

Tabel 3.1.

Tabel 3.2.

Overzicht van verschillen tussen de schattingsmodellen

Gemiddelden van de afhankelijke en onafhankelijke variabelen per onderzoekspopulatie (Model I en II) $\ldots \ldots \ldots \ldots \ldots .44$

Tabel 3.3. Resultaten logistische regressie-analyse ter verklaring van de vraag naar huisartsconsulten op eigen initiatief .........

Tabel 3.4. Elasticiteiten van de kans op een huisartsconsult op eigen initiatief ten aanzien van tijd en tijdprijs . . . .........51

Tabel 3.5. Resultaten logistische regressie-analyse ter verklaring van de vraag naar huisartsconsulten niet op eigen initiatief .......

Tabel 4.1. Gemiddelden van de afhankelijke en onafhankelijke variabelen per onderzoekspopulatie (Model III en IV) . . . . . . . . . 61

Tabel 4.2. Resultaten logistische regressie-analyse ter verklaring van het medicijngebruik op recept huisarts . . . . . . . . . . 63

Tabel 4.3. Elasticiteiten van de kans op gebruik van medicijnen op voorschrift van de huisarts ten aanzien van tijd en tijdprijs ... 65

Tabel 4.4. Resultaten logistische regressie-analyse ter verklaring van het medicijngebruik niet op recept $\ldots \ldots \ldots \ldots \ldots \ldots \ldots 66$

Tabel 5.1. Gemiddelden van de afhankelijke en onafhankelijke variabelen per onderzoekspopulatie (Model V en VI) . . . . . . . 72

Tabel 5.2. Resultaten logistische regressie-analyse ter verklaring van de kans op een eerste specialistconsult . . . . . . . . . 73

Tabel 5.3. Resultaten logistische regressie-analyse ter verklaring van de kans op een herhalingsconsult bij de specialist . . . . . . . 75

Tabel 6.1. Gemiddelden van de afhankelijke en een aantal onafhankelijke variabelen per onderzoekspopulatie (Model VII) .........

Tabel 6.2 Gemiddelden van de afhankelijke en een aantal onafhankelijke variabelen per onderzoekspopulatie (Model VIII) .........

Tabel 6.3. Resultaten logistische regressie kans op minstens eén

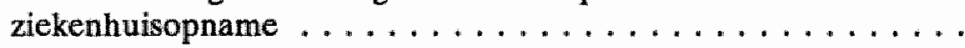

Tabel 6.4. Gevoeligheid van opnamekans voor een verandering in de tijdprijsindicatoren .....................

Tabel 6.5. Resultaten regressie-analyse verpleegduur door middel van de gewone kleinste kwadraten methode . . . . . . . . . . .

Tabel 7.1. Overzicht van predicties op basis van het investerings- resp. het consumptiemodel van Grossman ............. 96

Tabel 7.2. Resultaten logistische regressie-analyse ter verklaring van de vraag naar gezondheid als voorraadgrootheid ...........

Tabel 7.3. Gevoeligheid van de gezondheid voor een verandering in de tijdwaarderingsindicatoren ................ 100 
Tabel 7.4. Resultaten logistische regressie-analyse ter verklaring van de vraag naar gezondheid als stroomgrootheid ........... 101

Tabel 7.5. Effecten op de kans op geen. DBA als gevolg van een verandering in de tijdwaarderingsindicatoren op basis van Model

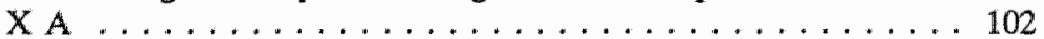

Tabel 8.1. Overzicht van tijdsbestedingen aan medische verzorging buitenshuis en thuis in minuten per week . . . . . . . . . 109

Tabel 8.2. Overzicht van indirecte kosten van ambulante medische zorg (thuis en buitenshuis) in guldens . . . . . . . . . . 111

Tabel 8.3. Indirecte kosten van klinische zorg in ziekenhuizen in 1981 in miljoenen guldens . . . . . . . . . . . . . . . 113

Tabel 8.4. Relevante gegevens met betrekking tot directe en indirecte kosten van huisartsconsulten in $1981 \ldots \ldots \ldots \ldots \ldots . . . .114$

Tabel 8.5. Relevante gegevens met betrekking tot directe en indirecte kosien van farmaceutische hulp in $1981 \ldots \ldots \ldots \ldots \ldots . . \ldots 115$

Tabel 8.6. Relevante gegevens met betrekking tot directe en indirecte kosten van niet-klinische specialistische hulp in $1981 \ldots \ldots 117$

Tabel 8.7. Relevante gegevens met betrekking tot directe en indirecte kosten van ziekenhuisopname in $1981 \ldots \ldots \ldots \ldots \ldots$

Tabel 8.8. Indirecte kosten als percentage van de directe kosten voor een aantal consumptiecategorieèn . . . . . . . . . . . . . . 129

Tabel 8.9. Kosteneffecten van een denkbeeldige afname van tijdprijzen met

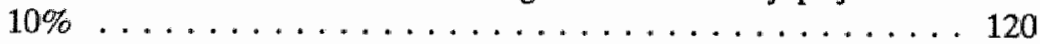

Tabel 9.1. Overzicht van effect van tijdsbesteding op medische consumptie 129

Tabel 9.2. Overzicht van effecten van tijdprijzen op medische consumptie . 130 Tabel 9.3. Overzicht van effecten tijdsbesteding op gezondheid . . . . . 131

Tabel 9.4. Overzicht van effecten van tijdswaardering op gezondheid . . . 132 Tabel 9.5. Indirecte kosten van gezondheidszorg (1981) . . . . . . 132 Tabel 9.6. Procentuele effecten van afname van de tijdprijzen met $10 \% \ldots 133$

\section{LIJST VAN FIGUREN.}

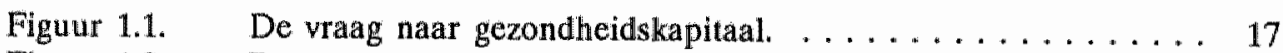

Figuur 1.2. Determinanten van gezondheidskapitaal $\ldots \ldots \ldots \ldots \ldots \ldots . \ldots 18$

Figuur 1.3. Effect van loon op de vraag naar gezondheidskapitaal . . . . . 19

Figuur 1.4. Effect van opleiding op de vraag naar gezondheidskapitaal. $\ldots 20$

Figuur 2.1. Gebruik medische voorzieningen in een jaar. . . . . . . . . . 30

Figuur 4.1. Gedragsalternatieven bij medicijnen-consumptie . . . . . . . . 58

Figuur 7.1. Relatie tussen gezondheidswoorraad en aantal gezonde dagen .. 92 
BIJLAGEN 


\section{BLILAGE 1. FORMELE AFLEIDING VAN DE PRIJS- EN INKOMENSEFFECTEN IN HET VRAAGMODEL NAAR MEDISCHE VOORZIENINGEN VAN ACTON}

In deze bijlage worden de centrale vergelijkingen van deze afleiding gepresenteerd. Voor de volledige afleiding wordt verwezen naar de bijlage van Acton (1973a).

De doelstellingsfunctie,

$\mathrm{U}=\mathrm{U}(\mathrm{m}, \mathrm{X})$

kan geoptimaliseerd worden onder de voorwaarde dat:

$(p+w t) m+(q+w s) X \leq Y=y+w T$

De aanname dat beide goederen $X$ en $m$ normaal zijn, dat wil zeggen een toename van de prijs leidt tot een afname van de vraag, impliceert dat de eerste afgeleidde van de doelstellingsfunctie positief is, de tweede negatief en de kruis-afgeleidde positief is. De optimumvoorwaarden kunnen gevonden worden met de multiplicatoren-methode van Lagrange. Hierbij worden (1) en (2) herschreven als

$\mathrm{L}=\mathrm{U}(\mathrm{m}, \mathrm{X})+\lambda[\mathrm{m}(\mathrm{p}+\mathrm{wt})+\mathrm{X}(\mathrm{q}+\mathrm{ws})-\mathrm{y}-\mathrm{wT}]$

en vervolgens wordt deze functie gedifferentieerd naar $m, X$ en $\lambda$

In het optimum moet nu voldaan zijn aan de volgende drie eerste orde voorwaarden,

waarin $U_{m}=\frac{\delta U}{\delta m}$ en $U_{x}=\frac{\delta U}{\delta x}$

$\delta \mathrm{L}$

$\overline{\delta m}=U_{m}+\lambda(p+w t)=0$

$\delta \mathrm{L}$

$\overline{\delta \mathrm{X}}=\mathrm{U}_{\mathrm{x}}+\lambda(\mathrm{q}+\mathrm{ws})=0$

$\delta L$

$\overline{\delta \lambda}=\mathrm{m}(\mathrm{p}+\mathrm{wt})+\mathrm{X}(\mathrm{q}+\mathrm{ws})-\mathrm{y}-\mathrm{wT}=0$ 
Een effect van een verandering in de geldprijs $\mathrm{p}$ op de vraag naar $\mathrm{m}$ wordt gevonden door het stelsel van de vergelijkingen $4 a$, $4 b$ en $4 c$ te defferentiëren naar $p$. Oplossing met behulp van de regel van Cramer geeft

$\frac{\delta \mathrm{m}}{\delta \mathrm{p}}=\frac{-m U_{\mathrm{mx}}(\mathrm{q}+\mathrm{ws})+\mathrm{mU} U_{\mathrm{xx}}(\mathrm{p}+\mathrm{wt})+\lambda(\mathrm{q}+\mathrm{ws})^{2}}{|\mathrm{D}|}$

Omdat de tweede-orde afgeleidde $U_{x x}$ en $U_{\operatorname{mm}}<0$ en $U_{x m}$ en $U_{m x}>0$ en daarnaast $\lambda$ negatief is (zie 4a) is aan te tonen dat de determinant $|D|$ van het stelsel van vergelijkingen van tweede-orde afgeleidden positief is en derhalve

$\delta \mathrm{m}$

- negatief is.

$\delta p$

Het effect van een verandering in de tijdprijs op de vraag naar $m$ kan op vergelijkbare wijze uitgedrukt worden,

$\frac{\delta m}{\delta t}=\frac{-m w U_{m x}(q+w s)+m w U_{x x}(p+w t)+\lambda w(q+w s)^{2}}{|D|}$

N.B. Hierbij neemt Acton aan dat de tijdprijs verandert als gevolg van een verandering in $t$ en w onveranderd blijft.

Hieruit blijkt dat

$\delta \mathrm{m}$

- eveneens negatief zal zijn.

$\bar{\delta} \mathrm{t}$

Uit (5) en (6) volgt dat $\frac{\delta \mathrm{m}}{\delta \mathrm{t}}=\mathrm{w} \frac{\delta \mathrm{m}}{\delta \mathrm{p}}$

Op vergelijkbare wijze kan het effect van een verandering in de totale prijs berekend worden:

$\frac{\delta m}{\delta(p+w t)}=\frac{-m U_{m x}(q+w s)+m U_{x x}(p+w t)+\lambda(q+w s)^{2}}{|D|}$

Op grond waarvan blijkt dat,

$\frac{\delta m}{\delta(p+w t)}=\frac{\delta m}{\delta p}$ 
De relatie tussen de 3 prijselasticiteiten ziet er als volgt uit:

$\eta_{m(p+w i)}=\frac{\delta m}{\delta(p+w t)} \cdot \frac{(p+w t)}{m}=\frac{\delta m}{\delta p} \cdot \frac{(p+w t)}{m}$

oftewel

$\frac{\delta m}{\delta p}=\eta_{m(p+m)} \cdot \frac{m}{(p+w i)}$

Daarnaast geldt dat

$\eta_{\mathrm{mt}}=\frac{\delta \mathrm{m}}{\delta \mathrm{t}} \cdot \frac{\mathrm{t}}{\mathrm{m}}=\frac{\delta \mathrm{m}}{\delta \mathrm{wt}} \cdot \frac{\mathrm{wt}}{\mathrm{m}}=\eta_{\mathrm{m}(\mathrm{wt})}$

Uit (7) volgt nu dat $n_{\mathrm{m}(w)}=\mathrm{w}-\frac{\mathrm{t}}{\mathrm{m}} \cdot \frac{\delta \mathrm{m}}{\delta \mathrm{p}}$

Substitutie van $(9 a)$ hierin leidt tot

$$
\eta_{m(w t)}=\frac{w t}{m} \cdot \frac{m}{(p+w t)} \eta_{m(p+w t)}=\frac{w t}{(p+w t)} \eta_{m(p+w t)}
$$

Uit (9a) volgt tevens dat

$$
\eta_{m p}=\frac{\mathrm{m}}{(p+w t)} \cdot \frac{\mathrm{p}}{\mathrm{m}} \cdot \eta_{m(p+w t)}=\frac{\mathrm{p}}{(p+w t)} \cdot \eta_{m(p+w t)}
$$

Hieruit blijkt tevens dat $\eta_{\mathrm{mp}} \frac{\geq}{<} \eta_{\mathrm{m}(\mathrm{wt})}$

gegeven: $\mathrm{p} \geq \mathrm{wt}$

Het effect van een verandering in inkomen kan uitgesplitst worden in een verandering in $y$, het overige inkomen, en in verandering in $w$, het inkomen uit arbeid.

Differentiëring van het stelsel vergelijkingen $(4 a, 4 b, 4 c)$ naar y resulteert in:

$\frac{\delta m}{\delta y}=\frac{U_{m x}(q+w s)-U_{x x}(p+w t)}{|D|}$ 
Zolang als $m$ functioneert als een normaal goed zall $\frac{\delta \mathrm{m}}{\delta y}$ in alle gevallen een positieve waarde hebben.

Berekening van het effect van een verandering in de loonvoet $w$ op wergelijkbare wijze leidt tot:

$$
\frac{\delta m}{\delta w}=\frac{(T-m t-X s) U_{m x}(q+w s)-(T-m t-X s) U_{x x}(p+w t)-\lambda s(q+w s)(p+w t)+\lambda t(q+w s)^{2}}{|D|}
$$

Dit effect kan opgesplitst worden in een inkomens- en substitutie-effect:

$$
\frac{\delta m}{\delta w}=(T-m t-X s) \frac{\delta m}{\delta y}-\frac{\lambda s(q+w s)(p+w t)-\lambda t(q+w s)^{2}}{|D|}
$$

Op basis van eerdere aannames is de eerste term, die het inkomenseffect weergeeft, positief.

Gegeven dat $\lambda$ negatief is, kan aangetoond worden dat de tweede term alleen dan positief is indien

$\frac{w s}{(q+w s)}>\frac{w t}{(p+w t)}$

Hieruit blijkt dat er alleen dan van een positief substitutie-effect sprake zal zijn indien de tijdprijscomponent van de totale prijs van $\mathrm{X}$ groter is dan van $\mathrm{m}$.

Tevens blijkt uit (12) dat indien de geldprijs van $m$ nul is, bijvoorbeeld in geval van volledige verzekering, en $q$ positief is, niet meer voldaan wordt aan deze conditie. In dat geval is het substitutie-effect negatief. 


\section{BIJLAGE 2. HET INVESTERINGSMODEL VAN GROSSMAN}

Voor een uitgebreide beschrijving van het investeringsmodel wordt verwezen naar Grosisman (1972b, p. 1-30).

De doelstellingsfunctie van de consument wordt gedurende zijn leven geformuleerd als

$U=U\left(\phi_{0} H_{0} \ldots, \phi_{n} H_{n}, Z_{0} \ldots, Z_{n i n}\right)$

Hierin staat $H_{o}$ voor het geêrfde gezondheidskapitaal en $H_{1}$ voor het gezondheidskapitaal bij leeftijd $\mathrm{i}(i=1,2, \ldots . \mathrm{n})$. $\phi_{\mathrm{i}}$ staat voor de dienstenstroom per eenheid gezondheidskapitaal en kan begrepen worden als de "gezonde tijd" die door de voorraad gezondheidskapitaal wordt geproduceerd. Deze "gezonde tijd" kan opgevat worden als de tijd dat men niet in zijn activiteiten belemmerd is door ziekte.

$Z_{1}$ staat voor alle andere in het huishouden voort te brengen goederen.

De netto-investeringen in de voorraad gezondheidskapitaal worden gedefinieerd als:

$H_{i+1}-H_{i}=I_{i}-\delta_{i} H_{i}$

Hierin is $I_{i}$ de bruto-investering in gezondheid en $\delta_{i}$ de depreciatievoet van de voorraad gezondheidskapitaal in het i-de jaar. Deze depreciatievoet functioneert als een exogene in het model en aangenomen wordt dat deze positief samenhangt met de leeftijd van het individu.

De huishoudproduktiefunctie voor de gezondheidsinvesteringen $I_{i}$ en de overige goederen worden geformuleerd als:

$I_{i}=I_{i}\left(M_{i,}, T_{j}: E_{i}\right)$

$Z_{i}=Z_{i}\left(X_{i}, T_{i}: E_{i}\right)$

In deze vergelijkingen staat $\mathrm{M}_{i}$ voor medische voorzieningen en $\mathrm{X}_{i}$ woor de inputs van marktgoederen in de produktie van $Z_{i}$. $T_{\|}$en $T_{i}$ staan voor de respectievelijke tijdinputs in de produktie van $I_{i}$ en $Z_{i}$. Tot slot staat $E_{i}$ voor het opleidingsniveau. Verondersteld wordt dat bij een toename hiervan de efficiëncy in de produktie van $I_{i}$ en $Z_{1}$ zal toenemen.

Daarnaast wordt aangenomen dat de produktiefunctie homogeen is van de eerste graad. Dit betekent dat er sprake is van constante meeropbrengsten bij vergroting van de produktie-omvang. Deze eigenschappen van de produktiefunctie kunnen worden weergegeven in de homogeen lineaire variant van de "Cobb en Douglas" produktiefunctie. De produktie-elasticiteiten zijn hierbij constant en samen gelijk aan 1 (Van Montfort, 1980; Heathfield en Wibe, 1987, p. 81).

Optimalisatie van de doelstellingsfunctie vindt plaats onder de voorwaarden van een tweetal budgetretricties.

De eerste is de monetaire budgetrestrictie, die geschreven kan worden als

$$
\sum \frac{P_{i} M_{i}+F_{i} X_{i}}{i(1+r)^{i}}=\sum \frac{W_{i} W_{i}}{i(1+r)^{i}}+A_{o}
$$


Hierin zijn $P_{i}$ en $F_{i}$ de prijzen van $M_{i}$ en $X_{i}$, is $W_{i}$ de loonvoet en staat $T W_{i}$ voor de arbeidstijd. $A_{0}$ is het verdisconteerde inkomen uit vermogensbezit en $r$ is de rentevoet.

De tweede budgetrestrictie heeft betrekking op de totaal beschikbare tijd $\Omega$

$\Omega=T W_{i}+T_{H}+T_{i}+T L_{i}$

Hierin staat $T L_{i}$ voor de tijd die als gevolg van ziekte niet meer beschikbaar is voor anderen als nuttig ervaren activiteiten. Verondersteld wordt dat $T L_{\mathrm{i}}$ negatief gerelateerd is aan de voorraad gezondheidskapitaal $\mathrm{H}_{\mathrm{i}}$. Indien $\Omega$ gemeten wordt in dagen en $\phi_{\mathrm{i}}$ gedefinieerd wordt als de opbrengst van gezonde dagen voortgebracht door én eenheid $\mathrm{H}_{\mathrm{i}}$, waarbij $\mathbf{h}_{\mathrm{i}}=\phi_{\mathrm{i}} \mathrm{H}_{\mathrm{i}}$, dan kan $\mathrm{TL}_{\mathrm{i}}$ gedefinieerd worden als:

$\mathrm{TL}_{\mathrm{i}}=\Omega-\mathrm{h}_{\mathrm{i}}$

De optimale voorraad gezondheidskapitaal kan op basis van het voorgaande afgeleid worden. Omdat de beginvoorraad én de depreciatievoet als exogenen worden beschouwd bepaald de optimale omvang van de bruto-investeringen tevens de optimale omvang van de voorraad gezondheidskapitaal. Aannemende dat er alleen sprake is van indirect nut, wordt de volgende optimumvoorwaarde gevonden:

$\mathrm{G}_{i} \mathrm{~W}_{\mathrm{i}}=\mathbb{I}_{\mathrm{j}-1}\left(\mathrm{r}+\bar{\delta}_{\mathrm{i}}\right)$

Hierin is $G_{i}$ gelijk aan $\delta h_{h} / \delta H_{i}$ oftewel $G_{i}$ is gelijk aan het marginaal produkt van $H_{i}$ ten aanzien van gezonde tijd. $G_{i} W_{i}$ kan opgevat worden als de marginale monetaire opbrengst van gezondheidsinvestering en in periode $i$. Het is de waarde van de tijd die is vrijgekomen voor de produktie van $I$ of $Z$ ten gevolge van de extra investering. $\Pi_{i=1}$ is gelijk aan de marginale kosten van gezondheidsinvesteringen in periode i-1. Aan de rechterkant van vergelijking (8) staan de kosten van gezondheidskapitaal in de betreffende periode. Deze bestaan nl. uit $\pi_{i-1} r$, het bedrag dat men opgeeft door niet in andere activiteiten te investeren ( $r$ is de rentevoet) en $\pi_{i-1} \delta_{i}$, het verlies dat men leidt als gevolg van de depreciatie van gezondheidskapitaal. Kortom de optimumvoorwaarde houdt in dat een rationeel handelend individu zal doorgaan met investeringen in zijn gezondheid totdat de marginale opbrengsten ervan gelijk zijn aan de marginale kosten. Deze laatsten worden verondersteld constant te zijn als gevolg van de eerder gemaakte aannames ten aanzien van de eigenschappen van de produktiefunctie. Vergelijking (8) laat tevens zien dat indien er in een bepaalde periode geen investeringen plaatsvinden, de marginale kosten van een bruto-investering groter zullen zijn dan de marginale opbrengsten. Er kan derhalve in een dergelijke situatie niet voldaan worden aan deze optimumconditie. Indien beide zijden van vergelijking (8) gedeeld worden door de marginale kosten van gezondheidsinvesteringen wordt een uitdrukking gevonden voor de monetaire opbrengstvoet van een investering in gezondheidskapitaal:

$$
\gamma_{i}=\frac{G_{i} W_{i}}{\Pi_{i-1}}=(r+\delta)
$$

Deze uitdrukking voor $\gamma_{i}$ wordt door Grossman ook wel de marginale efficiëntie van gezondheidskapitaal genoemd. 
Figuur 1.1. in hoofdstuk 1 laat zien dat de curve van $\gamma$, een dalend verloop heeft, aannemende dat de produktiviteit van gezondheidskapitaal in termen van gezonde tijd $\left(G_{i}\right)$ daalt naarmate $H_{i}$ toeneemt. 
क

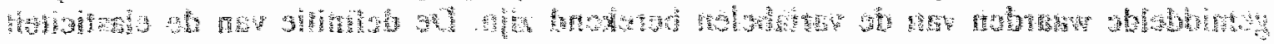

$h_{i} \quad$ Aantal gezonde dagen in periode $i$

$\mathrm{H}_{\mathrm{i}} \quad$ Gezondheidsvoorraad in periode $\mathrm{i}$

$W_{i} \quad$ Loonvoet

$\mathrm{G}_{\mathrm{i}} \quad$ Marginaal produkt van de gezondheidsvoorraad uitgedrukt in thet antal extra gezonde dagen die een investering in gezondheid voortbrengt

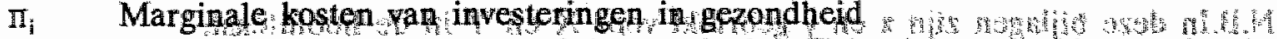

$\chi$ Monetaire opbrengstenwoet of de marginale efficièntie van een investering in gezondheid

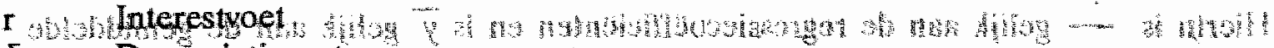

$\delta_{i} \quad$ Depreciatievoet

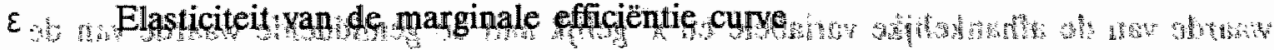

$\tilde{\Pi}_{i} \quad$ procentuele verandering in $\Pi_{i}$

$\bar{\delta}_{i} \quad$ procentuele verandering in $\delta_{i}$

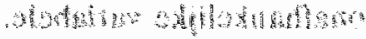

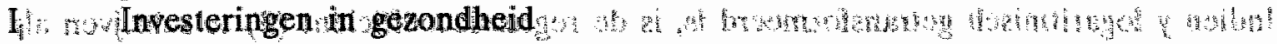

$\mathbb{E}_{\mathrm{i}} \quad$ Opleidingsniveau

$\mathrm{M}_{\mathrm{i}} \quad$ Inputs van medische voorzieningen bij de produktie vangezondheid $(\mathrm{F})$

$\mathrm{TH}_{\mathrm{i}} \quad$ Tijdinputs bij de produktie van gezondheid $\left(\mathrm{I}_{i}\right)$

$\mathbf{r}_{\mathrm{H}} \quad$ Procentuele verandering in de gezondheidsinvesteringen als gevolg van een verandering in opleiding

$\alpha_{1} \quad$ Omvang van de inputs van medische voorzieningen bij de produktie van gezondheid

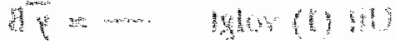

$\mathbb{K}$ Omvang van de tijdinputs bij de produktie van gezondheid $\left(K=1-\alpha_{1}\right)$

$\sigma_{p} \quad$ Substitutie-elasticiteit tussen medische voorzieningen en tijdinputs bij de

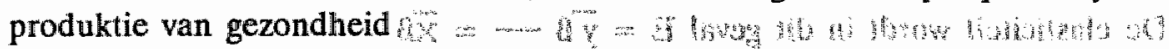

$C_{i} \quad$ Kosten van investeringen in gezondheid

$\mathbb{P}_{i} \quad$ Prijs van medische voorzieningen $\left(\mathrm{M}_{\mathrm{i}}\right)$

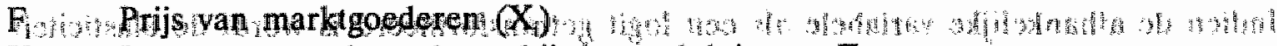

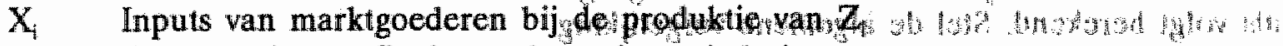

$Z_{i} \quad$ Consumptie van finale goederen in periode $i$

$\mathrm{T}_{\mathrm{i}} \quad$ Tijdinputs bij de produktie van $\mathrm{Z}_{\mathrm{i}}$

TW, Aantal uren betaald werk

$A_{0} \quad$ Inkomen uit vermogen

绾

$\varepsilon_{H, W} \quad$ Elasticiteit van de gezondheidsvoorraad $(\mathrm{H})$ ten opzichte van een verandering in $W$

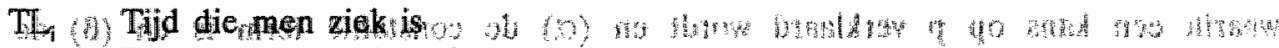

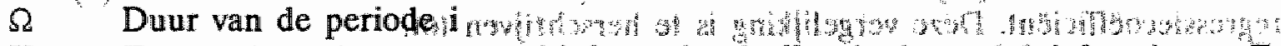

$\mathrm{X}_{\mathrm{i}} \quad$ Een marktgoed met een positief marginaal effect in de produktiefunctie van $\mathrm{Z}_{4}$

$X_{2} \quad$ Een marktgoed met een negatief marginaal effect in de produktiefunctie van $Z_{4}$

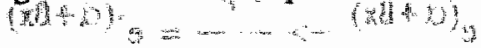


De in dit onderzoek gehanteerde elasticiteiten (E) zijn puntelasticiteiten, die bij de gemiddelde waarden van de variabelen berekend zijn. De defimitie van de elasticiteit van $y$ tent gevolge van een verandering in $x$ luidt:

$E=\frac{d y}{d x} \cdot \bar{x}$

N.B.In deze bijlagen zijn $x$ en y gebruikt voor $X$ en $Y$ in de hoofdtekst.

Hierin is $\frac{d y}{d x}$ gelijk aan de regressiecoefficiënten en is $\bar{y}$ gelijk aan de gemiddelde waarde van de afhankelijke variabele en $\bar{x}$ gelijk aan de gemiddelde waarde van de onafhankelijke variabele.

Indien y logaritmisch getransformeerd is, is de regressiecoëfficient (B) te schrijven als

$B=\frac{d \ln y}{d x}=\frac{1}{y} \cdot \frac{d y}{d x}$

Uit (1) volgt $\frac{d y}{d x}=\bar{y} B$

De elasticiteit wordt in dit geval $E=\bar{y} B \frac{\bar{x}}{\bar{y}}=\bar{x} B$

Indien de afhankelijke variabele als een logit getransformeerd is wordt de elasticiteit als volgt berekend. Stel de algemene vergelijking

$\ln \frac{p}{1-p}=\alpha+B x$

waarin een kans op p verklaard wordt en (a) de constante term is en (B) de regressiecoefficiènt. Deze vergelijking is te herschrijven tot:

$\frac{p}{1-p}=e^{(\alpha+B x)} \rightarrow \frac{1-p}{p}=e^{-(\alpha+B x)}$ 


$$
\rightarrow \frac{1}{p}=1+\mathrm{e}^{-(\alpha+B x)} \rightarrow p=\frac{1}{1+e^{-(\alpha+B x)}}
$$

Differentiëren van deze functie naar $\mathbf{x}$ leidt tot

$$
\frac{d p}{d x}=\frac{-1 \cdot-B \cdot e^{-(B x+\alpha)}}{\left|1+e^{-(B x+\alpha)}\right|^{2}}=\frac{B e^{-(B x+\alpha)}}{\left|1+e^{-(B x+\alpha)}\right|^{2}}
$$

Omdat $\mathrm{e}^{-(B x+a)}=\frac{1-\mathrm{p}}{\mathrm{p}} \quad$ is (5) te schrijven als

$$
\frac{d p}{d x}=B \frac{1-p}{p} \cdot p^{2} \rightarrow \frac{d p}{d x}=B \cdot p(1-p)
$$

Uit (1) volgt dat $E=\frac{d p}{d x}=\frac{\bar{x}}{\bar{p}}=B \bar{x}(1-\bar{p})$

Tot slot de berekening van elasticiteiten in geval er in een model gebruik is gemaakt van interactieve dummy-variabelen (zie ook paragraaf 2.4.).

Stel dat het model de vorm heeft van de volgende vergelijking

$y_{i j}=a+B_{2} T_{i j}+B_{i} T_{j} D_{i}+\phi x_{i j}$

waarin $\mathrm{i}=1 \ldots 6$ (aantal tijdbestedingsgroepen), $\mathrm{j}=1 \ldots \mathrm{n}$ (aantal cases) en waarin $\mathrm{T}$ de benodigde tijdvariabele is en $D_{1}$ een dummy-variabele is om het behoren tot een bepaalde tijdbestedingsgroep aan te geven.

De elasticiteit van de referentiegroep (groep 2) is berekend op basis van:

$$
E=B_{2} \frac{\bar{T}_{2}}{\overline{y_{2}}}
$$


waarin $\overline{\mathfrak{T}}_{2}$ en $\bar{Y}_{2}$ de gemiddelde waarden van de variabelen van de betreffende referentiegroep zijn.

ris

De clasticiteiten van de overige groepen zijn berekend op basis van:

$E=\left(B_{2}+B_{i}\right) \frac{\overline{\mathbb{T}}_{i}}{\overline{y_{i}}}$

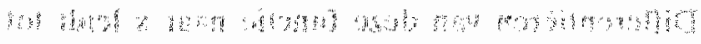

$$
\overline{y_{i}}
$$

(n)

$(1+x+y), \ldots$

Hierin zijn $\overline{\mathrm{T}}_{\mathbb{1}}$ en $\overline{\mathrm{Y}}_{\mathbb{1}}$ de gemiddelden van de betréffende deelpopulaties.

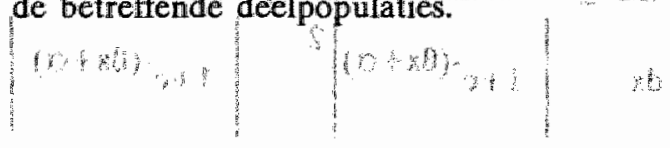

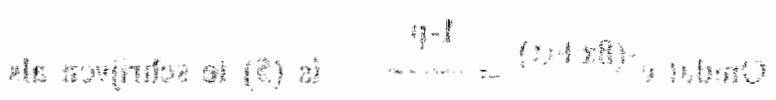

a

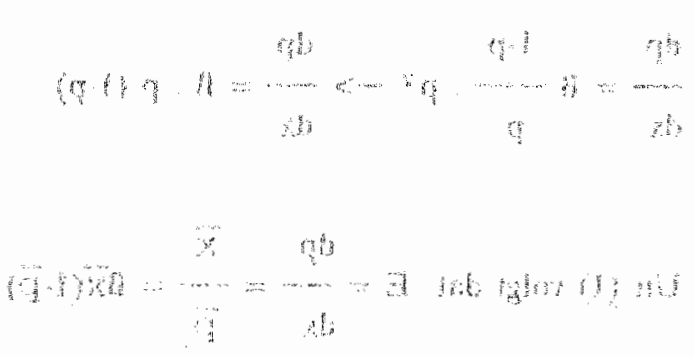

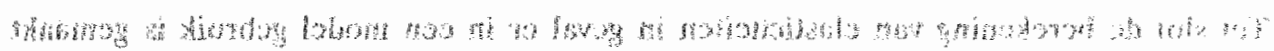

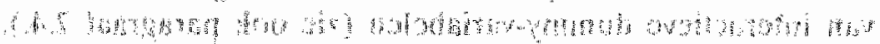

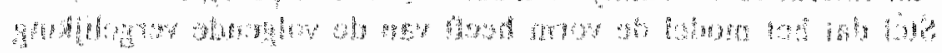

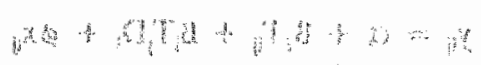

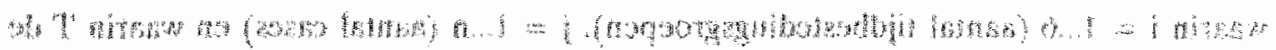

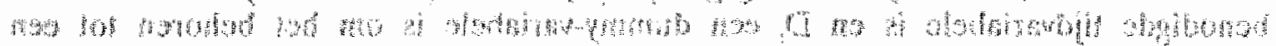

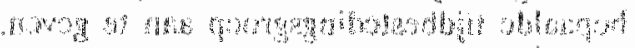

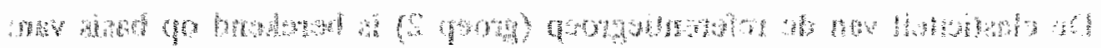

$\frac{1}{3}$ 


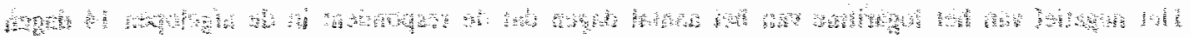

\section{Afhankelicke varinbelen:}

Model 1

Kans op consult op eligen initiatlef:

Dummy-variabele met de waarde 1 , indien de respondent de afgelopen drie maanden minstens éenmaal een consult op eigen initiatief bij de huisarts heeft gehad.

Model I

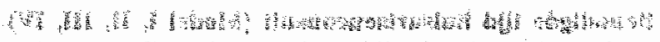

Kans op consult niet op eigen initiatier. Dummy-variabele met de waarde 1 , indien de respondent de afgelopen drie maanden minstens énmaal een consult niet op eigen initiatief bij de huisarts heseft gehad Dit zijn of herhglingsoon sulten of consulten die tot stand kwamen als gevolg xan een yerwizing door een andere arts spectalist of nog iemand andiers.

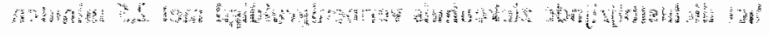

Model III

(a)

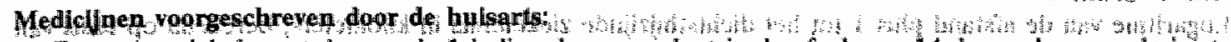
Dummy-variabele met de waarde 1 indien de respondent in de afgelopen, 4 dagen door een huisarts medicijnen heeft voorgeschreven gekregen.

Model $I Y$

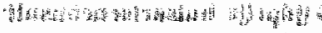

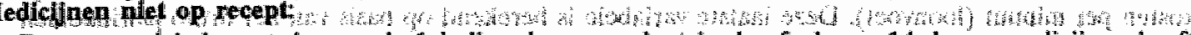
Dummy-wariabele met de waarde 1 indien de respondent in de afgelopen 14 dagen medicinen heeft gebruikt die niet waren voorgeschrewen, gekocht bij apotheker of drogist.

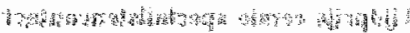

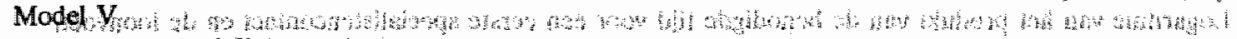

Kans eerste speciallstencontact:

Dummy-Wariabele met de waarde 1 indien de respondent in de afgelopen 3 magnden minstens 6 m $_{1}$

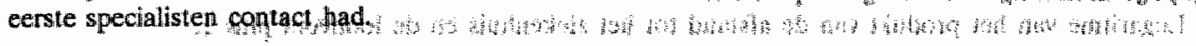

Model VI

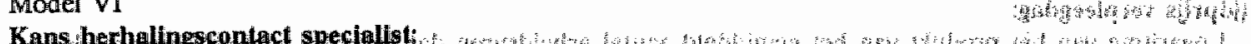

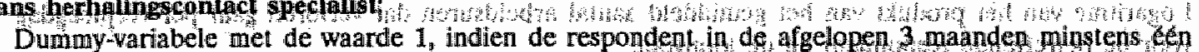
herhalingscontact had met de specialist.

\section{Model VII}

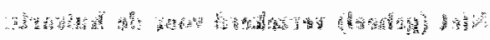

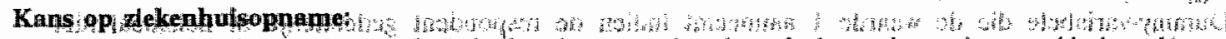
Dummy-kariabele met de warde 1 , indien de respondent het afgelopen jaar munstens esn keer langer dan een dag en een nacht in het ziekenhuis is opgenomen.

Modeli VII

Totale verpleegdunr ztehenhuis:

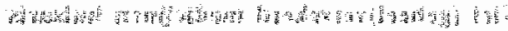
Logaritme van het aantal dagen dat de respondent in een ziekenhuis is opgenomen, voorwaar minstens een opname in het affielopen jaar .

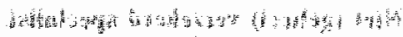

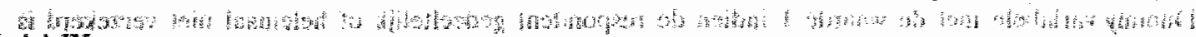
Model LX

Gezond heid:

का

Dummy-variabele met de waarde 1, indien de respondent zijn eigen gezondheid als "goed" begondeet

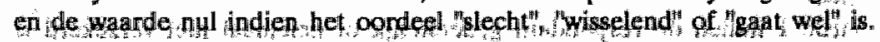

Model X:

Kans geen DBA: and Dummy wariabele die de warde 1 anneemt indien de respondent de afgelopen 14 dow dag had met belemmering in activiteiten als gevolg van ziekte, 
LN DIAA:

Het negatief van bet logaritme van het antal dagen dat dle respondent in de afgelopen 14 dagen belemmert was in zijn activiteiten als gevollg van ziekte.

\section{Ongrhankellike vardabelen:}

\section{Prilswartabelen:}

Benodligde tfd huilsartsenconsult (Model I, II, III, TV:

Logaritme wan de tijd nodig woor het afleggen van een bezoek aan de huisarts (incl. reis-, wacht-, en behandeltijd) in minuten.

\section{Benodigde tUd eerste spectallstencontact:}

Logartme wan de sommatie van de tijd nodig voor een huisartsenconsult en afstand (vica versa) tot het dichtsibijzijnde ziekenhuis vermenigvuldigd met 2,5 minuten.

\section{Afstand atekenhuls:}

Logaritme van de afstand plus 1 tot het dichtstbijzijnde ziekenhuis in kilometers, berekend op basis van de postcode van de respondent.

\section{Tudprifs hulsartsenconsult:}

Logaritme van de benodigde tijd, voor een huisartsenconsult vermenigvuldigd met de opportunitykosten per minutit (loonvoet). Deze laatste variabele is berekend op basis van het bruto jaarinkomen en de gemiddelde duur van de werkweek in uren.

\section{Tudprifs eersile spectallstencontact:}

Logaritme van thet produkt van de benodigde tijd voor een eerste specialistencontact en de loonvoet.

\section{Tujdptifs herhalingscontact by de speelallst:}

Logaritme van het produkt van de afstand tot het ziekenhuis en de loonvoet plus 1.

\section{Tudprifs verpleegdag:}

Logaritme van hel produkt van het gemiddeld aantal arbeidsuren dat verloren gaat per verpleegdag voor de betreffende respondent en de loonvoet.

Niel (geheel) verzekerd voor de hulsarts:

Dummy-variabele die de waarde 1 aanneemt indien de respondent gedeeltelijk of helemaal niet verzekerd is voor huisartsenhulp.

Nilet (geheel)verzekerd medicl|nen bulsarts:

Dummy-wariabele met de waarde 1 indien de respondent gedeeltelijk of helemasl niet verzekerd is voor medicijnen voorgeschreven door de huisarts.

Niet (geheel) verzekerd specinlist:

Dummy-yariabele met de waarde 1 indien dle respondent gedeeltelijk of helemal niet verzekerd is voor specialistische hulp.

Nitt (geheel) verzekerd zlekenhuls:

Dummy-kariabele met de waarde 1 indien de respondent gedeeltelijk of belemaal niet verzekerd is voor cen ziekenhuisopname.

Niet (geheel) verzekerd:

Dummy-variabele met de waarde 1 indien de respondent op minstens ten van de voorgaande vier dummy-variabele de waarde 1 scoorde. 
Full-1me loontrekkers (groep 1):

Dummy-variabele die de wasce 1 anneemt indien de respondent een diensiverband heeft van minstiens 40 uur en loon of salaris verdient.

Full-time direkteuren en zellstandigen (groep 2):

Dummy-variabele die de waarde 1 aanneemi indien de respondent directeur is van een NV of BV of medewerkend in een gezins- of familiebedriff, of zelfstandig, of werkzsam is op tree-lance basis en minstens 40 uur per week werkzaam is.

Volledig in het huishouden met kind (groep 3):

Dummy-variabele die de waarde 1 aanneemt, indien de respondent volledig werkaam is in do eigen huishouding en minstens én kind deel uitmaakt van de huishouding.

Scholleren en studenten (groep 4):

Dummy-variabele die de waarde 1 aanneemt indien de respondent een dagopleiding volgt en overigens geen werkkring heeft.

\section{Niei-actleven (groep 5):}

Dummy-variabele die de waarde 1 aanneemt indien de respondent een WAO, AAW-, werkloosheids- bijstandsuitkering of een combinatie hjervan geniet.

\section{Restgroep (groep 6):}

Dummy-variabele die de waarde 1 aanneemt indien de respondent niet valt onder éen van de 6 hierboven genoemde categorieèn. Het gaat hierbij met name om personen, die een dienstverband hebben van minder dan 40 uur en/of in het eigen huishouden werkzaam zijn, waar geen kinderen wan deel uitmaken.

\section{Inkomen:}

Hoogte van het netto huishoudinkomen onderverdeeld in 12 klassen oplopend van minder dan $f$ 12.500 tot meer dan $f \mathbf{6 5 . 0 0 0}$ netto per jaar.

\section{Loonvoet:}

Inkomen per minuut, berekend op basis wan de hoogte van het bruto-jaarinkomen en de gemiddelde duur van de werkweek.

\section{Annhodvariabelen:}

\section{Hulsartsendichtheld:}

Aantal huisartsen per 1000 inwoners per gemeente (Bron: Nederlans Huisartsen Instituut)

\section{Hulsarts apotheekhoudend:}

Dummy-variabele die de waarde 1 aanneemt indien de hulsarts wan de respondent cen apotheek heeft.

\section{Speciallistendichtheld:}

Aantal specialisten in algemene ziekenhuizen, berekend op basis wan patientenstromen, per 100,000 inwoners per gemeente (Bron: Geneeskundige Hoofdinspectie).

\section{Beddendlichtheld:}

Aantal bedden in algemene ziekenhuizen, berekend op basis van patientenstromen per 1000 inwoners op regionaal niveau (129 social-economische gebieden) (Bron: Geneeskundige Hoofdinspectie).

\section{Varlabelen met betrekling tol consumentroorikeuren:}

Leefiljd:

Leeftijd van de respondent in jaren. 


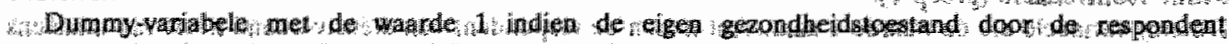

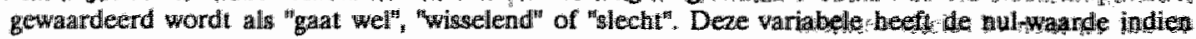
de respondent zujn gezondheidstoestand als "goed" beorideeld.

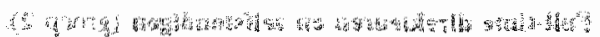

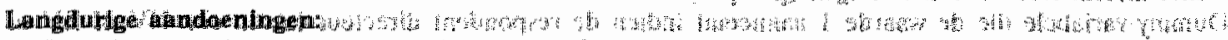

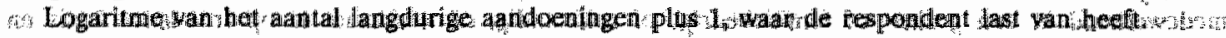

\section{Virouwen $18-45$ Jakr:}

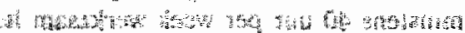

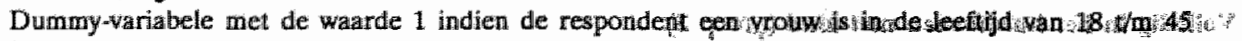

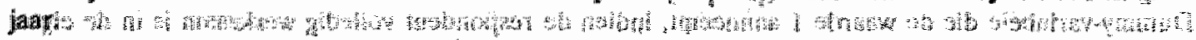

\section{Gesiacht:}

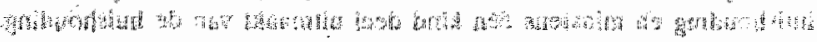

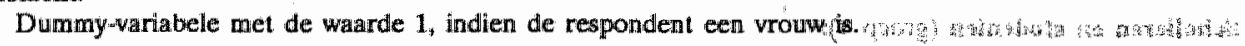

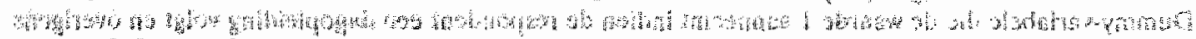

Dagen met belemmering In activiteiten:

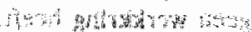

Dummy-variabele met de waarde 1 indien de respondent de afgelopen 14 dagen minstens een dag had waarop hij belemmerd was in zijn activiteiten als gevolg van ziekte.

\section{Oplelding:}

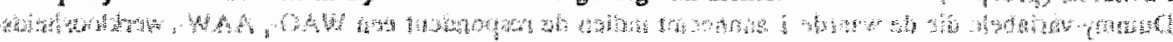
Hoogst pevolgde opleiding van de respondent onderverdeeld in vier klassen, $\mathrm{nl} 1$ is lager onderwijs, 2 is LAVO/LBO, 3 is HAVO/MBO, 4 is HBO/universiteit.

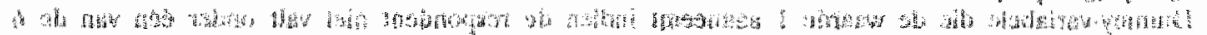

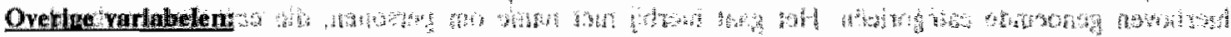

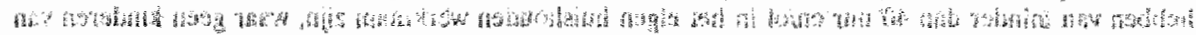

\section{Contact telefoon of visile:}

thing

Dummy-variabele met de wararde 1, indien de respondent een telefonische consult had of de huisarts bij haar thuis op visite is geweest in de afgelopen 3 maanden.

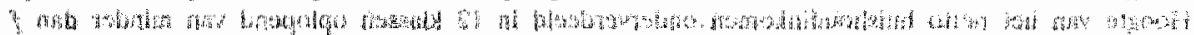

Hulshoudgrootle:

Logaritme van het aantal leden waruit het huishouden van de respondent bestaat.

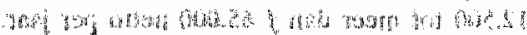

.

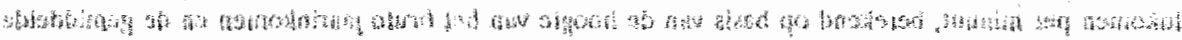
की

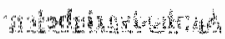

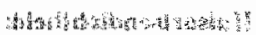

\{

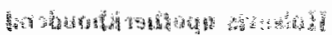

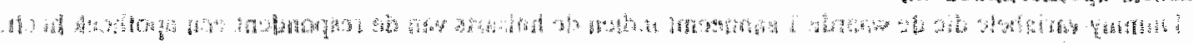

2.

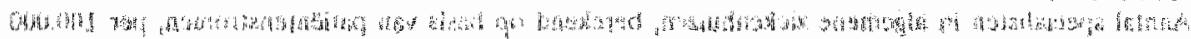

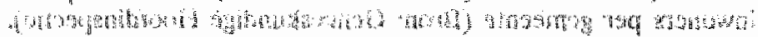

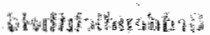

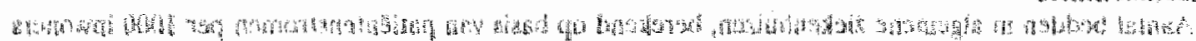

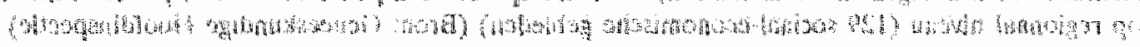

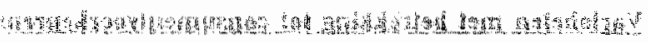




\begin{tabular}{|c|c|c|c|}
\hline \multirow{2}{*}{$\begin{array}{l}\text { Variabelen onschrijving } \\
\text { Kans op consult eigen init. (a) }\end{array}$} & \multicolumn{3}{|c|}{ 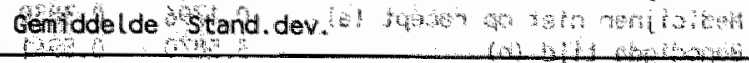 } \\
\hline & & 0 & 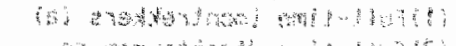 \\
\hline Kans op cons. niet eig.init. (a) & & & 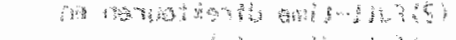 \\
\hline jd (b) & & & 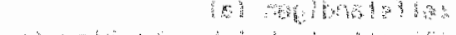 \\
\hline - tme coontrekker & & $1 / 590$ & 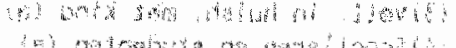 \\
\hline ren en & & Best n & 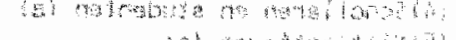 \\
\hline W sitantarts & 917 & 0.8467 & 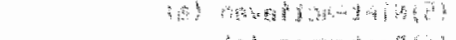 \\
\hline 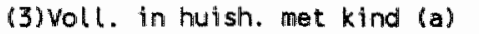 & & 1.4280 & $4 s^{4}$ \\
\hline & & 1.0169 & (a) \\
\hline$n 1$ & & & 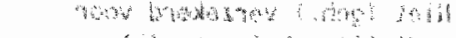 \\
\hline & & & 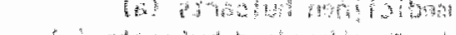 \\
\hline b) & & 0.6 & 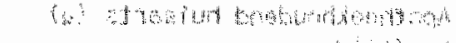 \\
\hline h.a. (a) & & 0.4377 & as. \\
\hline endichtheid & & & kf ant \\
\hline & & 13.6 & 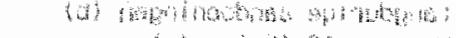 \\
\hline & & & 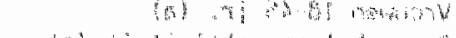 \\
\hline $\operatorname{gen}(b)$ & & 0.9 & 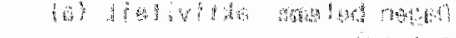 \\
\hline . (a) & & 0.4656 & \\
\hline elemm, aktiviteit (a) & & 0.3018 & \\
\hline & 2.4937 & 0.8697 & \\
\hline Rontakt telefo & 0.0275 & 0.1634 & \\
\hline
\end{tabular}

(a): De betreffende variabele is een dummy variabele

(b): De betreffende variabele is logaritmisch getransformeerd

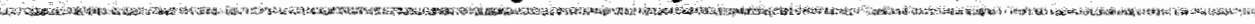

GEMIODELDEN EN STANDAARDDEVTATIES BEHOHENDE BIJ DE MODELLEN I C EN'II $\mathrm{C}$

\begin{tabular}{|c|c|c|c|}
\hline Variabelen omschrijuing & Gemiddelde & Stand dev. & 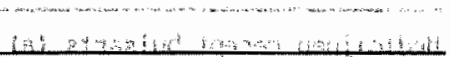 \\
\hline ans op consult & 0,3276 & 0,4694 & 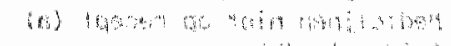 \\
\hline Kans op cons, ni & 0.0989 & 0.2987 & an: $17 y_{11}$ \\
\hline THjdprijs (b) & 2.4051 & 0.6309 & 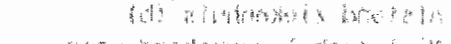 \\
\hline Af stand $z$ lekenhuis (b) & 1.7098 & 0.6427 & 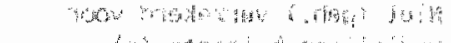 \\
\hline liet (geh.) verzek. h.a. (a) & 0.2421 & 0.4284 & 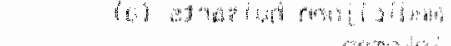 \\
\hline Inkomen & 31.550 & 28172 & mosems \\
\hline Loonvoet & $0.297 \%$ & 0.4505 & Hondeal \\
\hline Huisartsendichtheid & $0.3675^{4}$ & 0.079 & 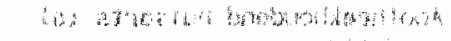 \\
\hline Leeftijd & $35,4080^{\circ}$ & 11.8177 & botsent \\
\hline Gezondheids & 0.1537 & 0.3607 & 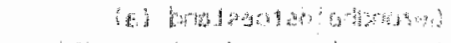 \\
\hline Langdurige aandoe & 0.1778 & 0.3474 & 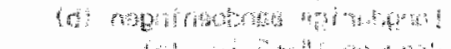 \\
\hline Wrouwen $18-45 \mathrm{jr}$ (a) & 0.2584 & 0.4379 & 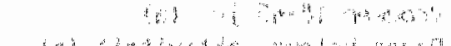 \\
\hline Dagen belem. aktiviteit (a) & 0,110 & 0.3141 & 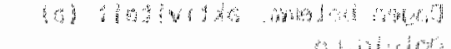 \\
\hline Opletding & 2.6840 & 0.8801 & \\
\hline Kantakt telefoon/visite (a) & 0.0245 & 0.1546 & \\
\hline * & $70097 \mathrm{n}$ & & \\
\hline
\end{tabular}

(a): De betreffende variabele is een dummy variabete.

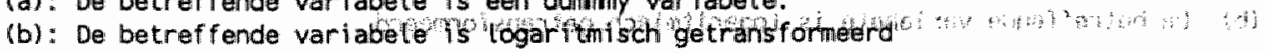


GEMIDDELDEN EN STANDAARDDEVIATIES BEHOAENDE BIJ DE MODELLEN III AB EN IV AB

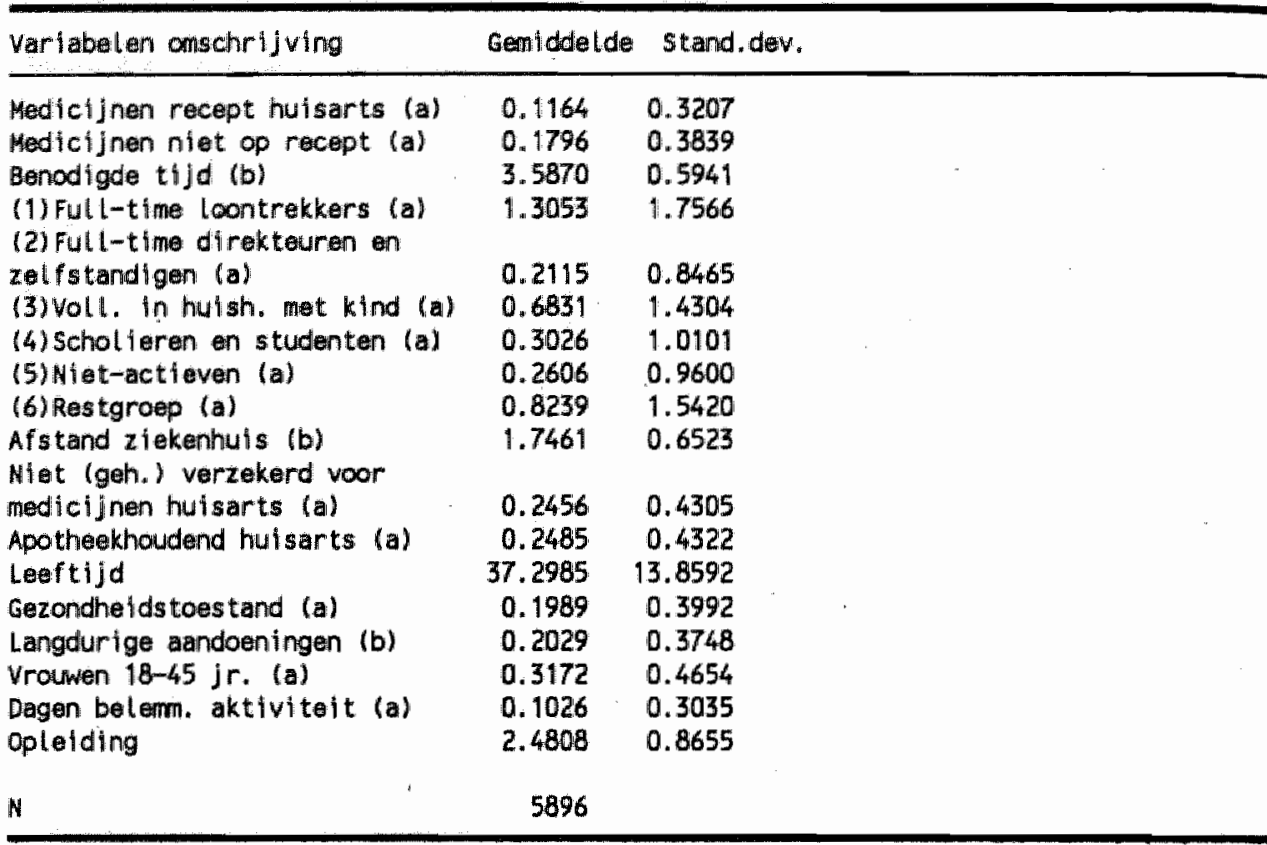

(a): De betreffende variabele is een dumy variabele

(b): De betreffende variabele is logarltmisch getransformeerd

GEMIDDELDEN EN STANDAARDDEVIATIES BEHORENDE BIJ DE MODELLEN III C EN IV C

\begin{tabular}{lrc}
\hline Variabelen omschrijuing & Gemiddelde & Stand.dev... \\
\hline Medicijnen recept huisarts (a) & 0.1092 & 0.3119 \\
Medicijnen niat op recept (a) & 0.1933 & 0.3950 \\
Tijdprijs (b) & 2.4007 & 0.6304 \\
Afstand zlekenhuis (b) & 1.7124 & 0.6436 \\
Niet (geh.) verzekerd voor & & \\
medicijnen huisarts (a) & 0.2310 & 0.4216 \\
Inkomen & 31.482 & 2.8151 \\
Loonvoet & 0.2963 & 0.1451 \\
Apotheekhoudend huisarts (a) & 0.2247 & 0.4175 \\
Laeftijd & 35.4591 & 11.7967 \\
Gezondheldstoestand (a) & 0.1557 & 0.3626 \\
Langdurige aandoeningen (b) & 0.1786 & 0.3483 \\
Vrouwen 18-45 Jr. (a) & 0.2594 & 0.4384 \\
Dagen belerm. aktiviteit (a) & 0.1116 & 0.3150 \\
Oplelding & 2.6706 & 0.8755 \\
& & \\
N & 2043 & \\
\hline
\end{tabular}

(a): De betreffende variabele is een dumy variabele

(b): De betreffende varlabele is logarl tmisch getransformeerd 
$V A / B \quad V I A / B$

Variabele onschrillwing

Gemidd. St.dev. Genidd, St.dev,

Kans op le spec. contact $(a)$

$0.0782 \quad 0.2685$

Kans op herh. cont. bij spec. (a)

Benodigde tijd le spec. cont. (b)

(1) Fulltine loontrekkers (a)

$4.1929 \quad 0.4547$

$0.1515 \quad 0.3586$

(2) fulltime directeuren en

zelfstandigen (a)

$1.5294 \quad 2.0310$

$0.6341 \quad 0.9216$

(3) voll. in huish. met kind (a)

$0.2551 \quad 1.0144$

$0.1135 \quad 0.4792$

$0.8048 \quad 1.6719$

$0.3470 \quad 0.7709$

(4) Scholieren en studenten (a)

$0.3526 \quad 1.1641$

(5) Niet-actieven (a)

(6) Restgroep (a)

0.29521 .0875

$0.1424 \quad 0.5014$

$\begin{array}{ll}0.9558 & 1.7697\end{array}$

$0.1191 \quad 0.4696$

Afs tand $z$ iekenhuils (b)

Niet (geh.) verzek. specialist (a)

Hui sartsendich theid

$0.1505 \quad 0.3576$

$\begin{array}{lll}0.3890 & 0.7775\end{array}$

$\begin{array}{lll}1.7451 & 0.6521\end{array}$

$0.3682 \quad 0.0751$

specialis tendichthe id Leef tijd

Gezondheids toes tand (a)

Langdurige aandoeningen (b)

Vrouwen 18-45 jr. (a)

$37.2260 \quad 13.8556$

$0.1505 \quad 0.3576$

Dagen belemerde activiteft (a)

apletding

$\begin{array}{ll}0.1966 & 0.3975\end{array}$

54.276217 .5257

37.226013 .8556

$0.2020 \quad 0.3742$

$0.1966 \quad 0.3975$

$\begin{array}{lll}0.3180 & 0.4657\end{array}$

$0.2020 \quad 0.3742$

$0.1017 \quad 0.3022$

$0.3180 \quad 0.4657$

$0.1017 \quad 0.3022$

$\begin{array}{llll}2.4911 & 0.8699 & 2.4911 & 0.8699\end{array}$

5960

(a): De betreffende variabele is een dumy variabele

(b): De betreffende variabele is logaritmisch getransformeerd

\section{GEMIDDELDEN EN STANDAARDDEVIATIES BEHOAENDE BU DE MODELLEN V C EN VI C}

\begin{tabular}{lrr}
\hline Variabelen onschrijving & Gemiddelde & Stand. dev. \\
\hline Kans op 1e spec. contact (a) & 0.0865 & 0.2812 \\
Kans op herh.cont. bij spec. (a) & 0.1281 & 0.3343 \\
Tijdprijs le spec. cont. (b) & 2.8632 & 0.6147 \\
Tijdprijs herh.spec. cont. (b) & 2.7169 & 0.3168 \\
Niet (geh.) verzek. speciallst (a) 0.1435 & 0.3507 \\
Inkomen & 31.558 & 2.8167 \\
Loonvet & 0.2974 & 0.1503 \\
Huisiartsendichtheid & 0.3675 & 0.0715 \\
Specialistendichtheid & 54.7345 & 17.4770 \\
Leeftijd & 35.3925 & 11.8112 \\
Gezondheidstoestand (a) & 0.1537 & 0.3607 \\
Langdurige aandoeningen (b) & 0.1783 & 0.3479 \\
Vrouwen 18-45 jr. (a) & 0.2610 & 0.4393 \\
Dagen belemmende activitit (a) & 0.1112 & 0.3144 \\
Opleiding & 2.6844 & 0.8793 \\
& & \\
N & 2069 & \\
\hline
\end{tabular}

(a): De betreffende variabele is een dumny variabele

(b): De betreffende variabele is logeritmisch getransformeerd 


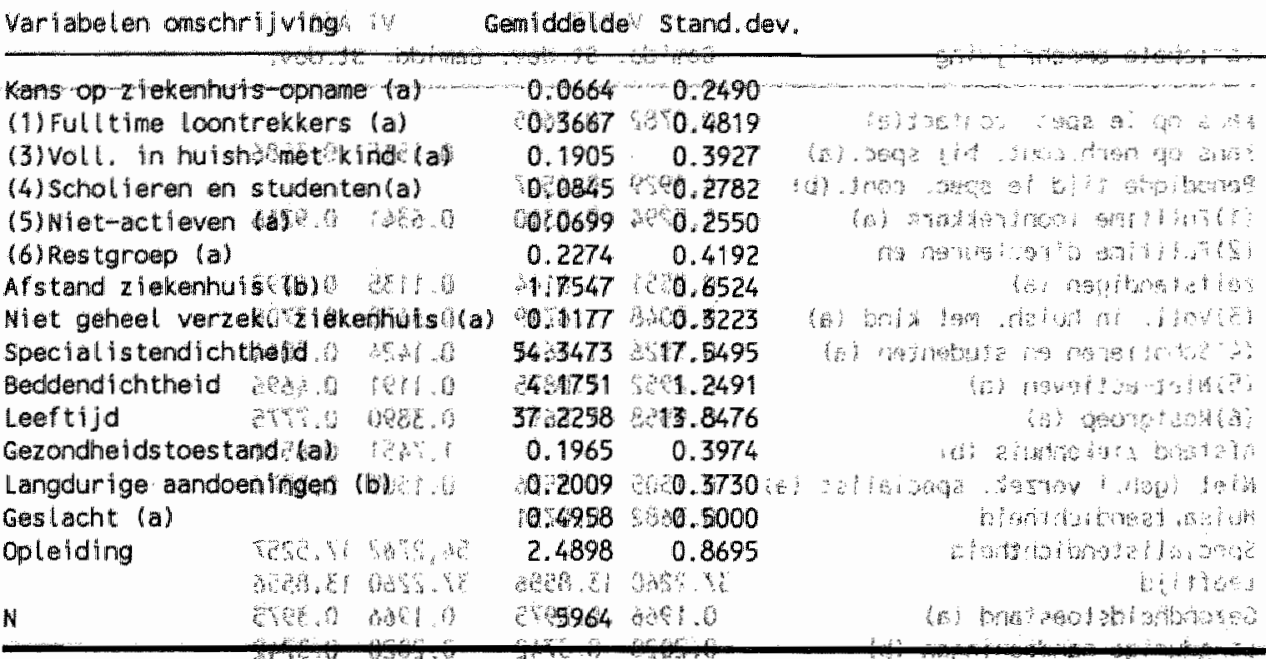

(a): De betreffendedvariabele is een dumy varfabele

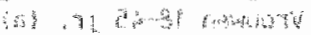

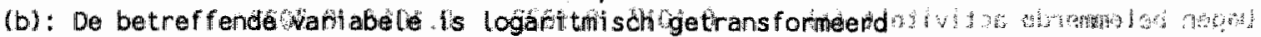

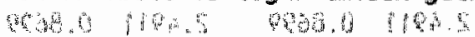

\section{GEMIDDELDEN EN STANDAARDDEVIATIES BEHORENDE BIJ HET MODEL VII C}

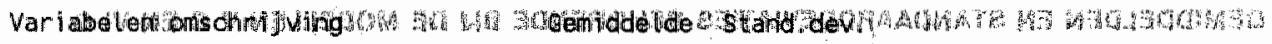

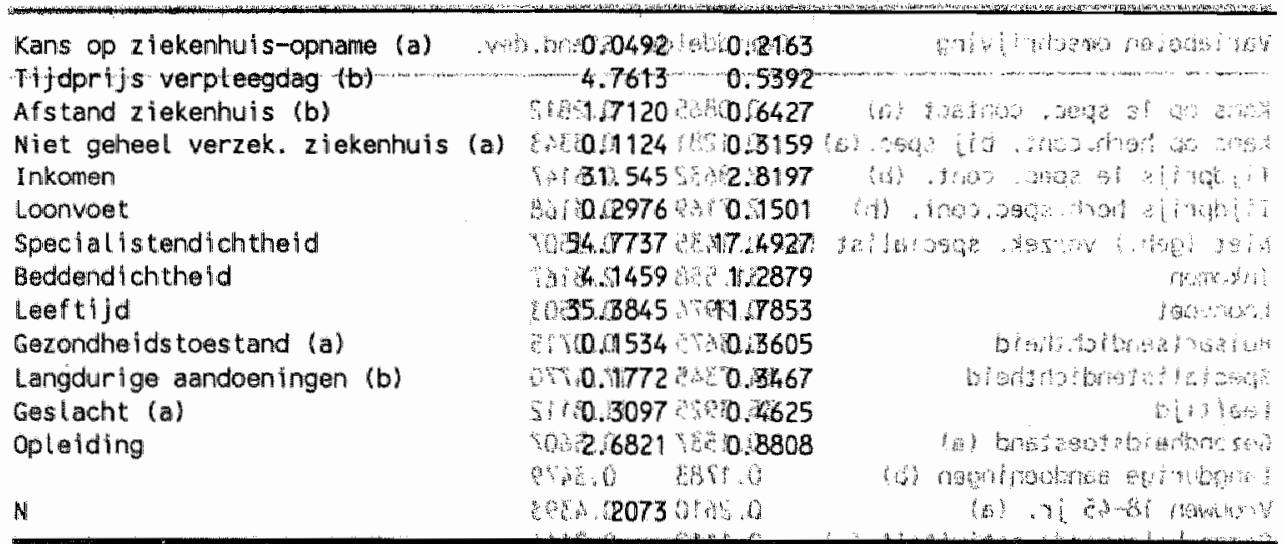

(a): De betreffende variabele is eeriduiny variabiele Q13:as

(b): De betreffende wariabele is logaritmisch getransformeerd astis 


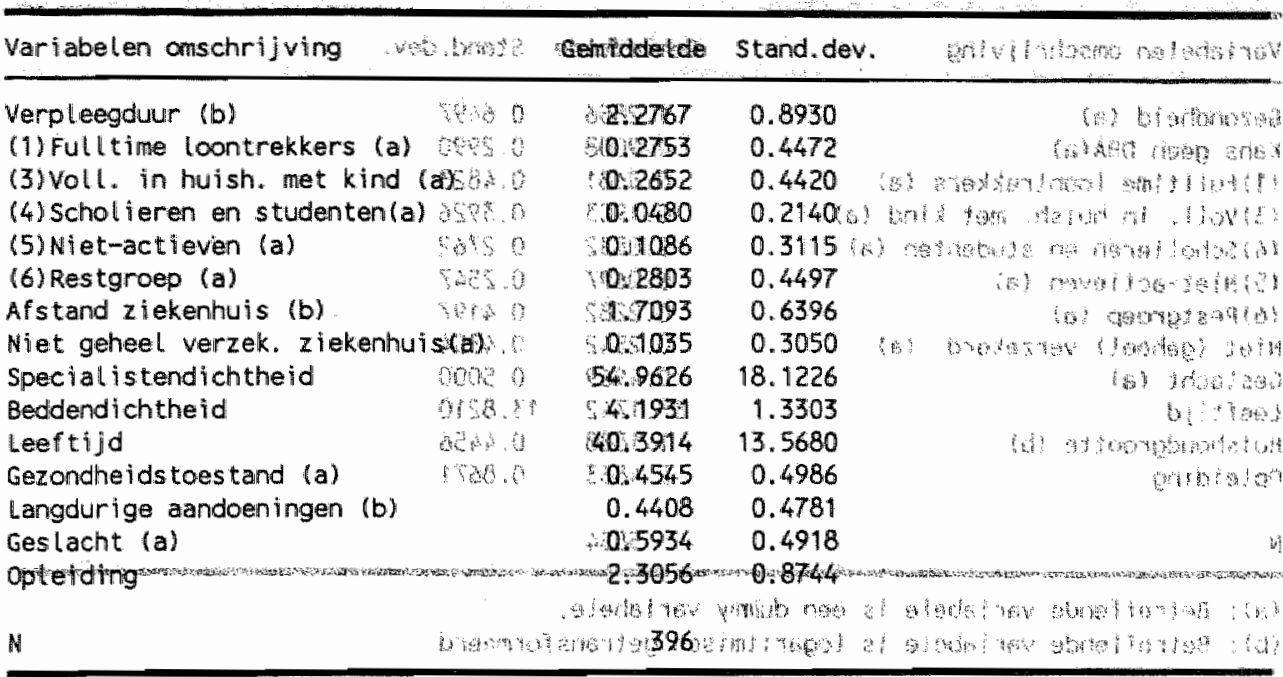

(a): De betreffende variabele is een dumy variabele

(b): De betreffende variabele is logaritmisch getransformeerd

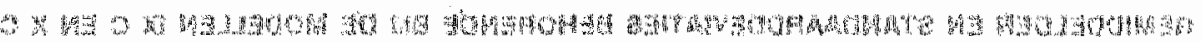
A w

GEMIDDELDEN EN STANDAARDDEVIATIES BEHORENDE BIJ HET MODEL MIIIC

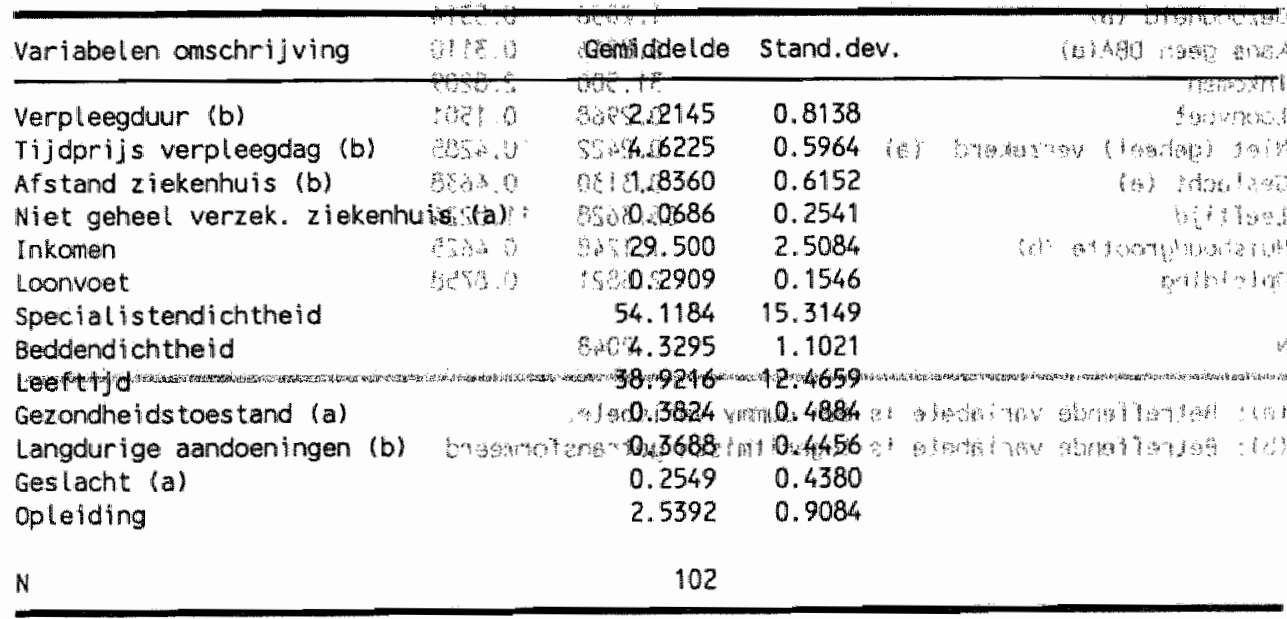

(a): De betreffende variabele is een dumy variabele

(b): De betreffende variabele is logaritmisch getransformeerd 
GEMUDDELDEN EN STANDAAFDDEVITIES BEHORENDE BU DE MODELLEN DX A EN X A

\begin{tabular}{|c|c|c|}
\hline Variabuten onschrijuing & Genildeletde & Stand. dev. \\
\hline 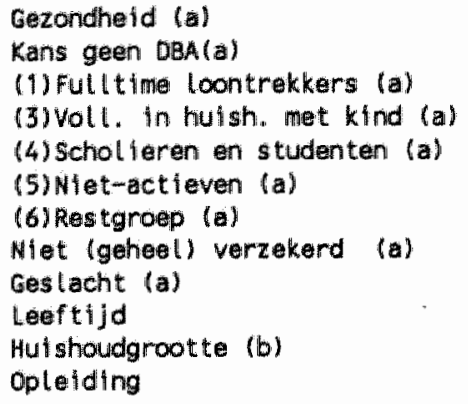 & $\begin{array}{l}1.2856 \\
0.9008 \\
0.3681 \\
0.1903 \\
0.0832 \\
0.0697 \\
0.2282 \\
0.2542 \\
0.4969 \\
37.1742 \\
1.1888 \\
2.4863\end{array}$ & $\begin{array}{l}0.6497 \\
0.2990 \\
0.4823 \\
0.3926 \\
0.2762 \\
0.2547 \\
0.4197 \\
0.4354 \\
0.5000 \\
13.8210 \\
0.4456 \\
0.8671\end{array}$ \\
\hline$N$ & 5854 & \\
\hline
\end{tabular}

(a): Betreffende varlabele is een dumy variabele.

(b): Betreffende variabele is logaritmisch getransformeerd

\section{GEMIDDELDEN EN STANDAARDDEVIATIES BEHORENDE BIJ DE MODELLEN IX C EN X C}

\begin{tabular}{|c|c|c|}
\hline Varlabelten omschrljwing & Gemiddelide & stand. dew. \\
\hline Gezondheld (a) & 1.2036 & 0.5314 \\
\hline Kans geen DBA $(a)$ & 0.8916 & 0.3110 \\
\hline Inkomen & 31.500 & 2.8209 \\
\hline Loonvoet & 0.2968 & 0.1501 \\
\hline Niet (geheel) verzekerd (a) & 0.2422 & 0.4285 \\
\hline Geslacht (a) & 0.3130 & 0.4638 \\
\hline Leeftljd & 35.3628 & 11.8224 \\
\hline Hul shoudgnoot to (b) & 1.1248 & 0.4625 \\
\hline opletding & 2.6821 & 0.8758 \\
\hline N & 2048 & \\
\hline
\end{tabular}

(a): Betreffende variabele is dumy variabele.

(b): Betreffende variabele is logaritmisch getransformeerd 


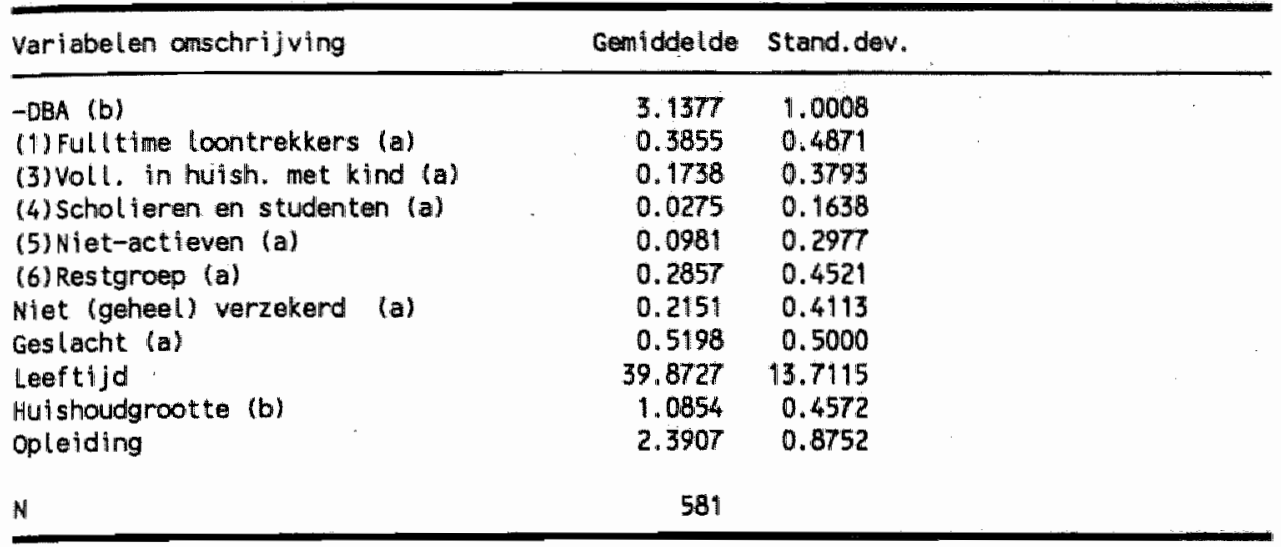

(a): Betreffende variabele is een dumy variabele.

(b): Betreffende variabele is logari tmisch getransformeerd

\section{GEMIDDELDEN EN STANDAARDDEVIATIES BEHORENDE BN HET MODEL X C'}

\begin{tabular}{lrr}
\hline Variabelen omschri]ving & Gemiddelde & Stand.dev. \\
\hline -DBA (b) & 3.3243 & 0.8890 \\
Inkomen & 31.350 & 2.7634 \\
Loonvoet & 0.2852 & 0.1368 \\
Niet (geheel) verzekerd (a) & 0.1802 & 0.3852 \\
Geslacht (a) & 0.3784 & 0.4861 \\
Leeftijd & 36.2567 & 12.2168 \\
Huishoudgrootte (b) & 1.0390 & 0.4707 \\
Opleiding & 2.5991 & 0.8805 \\
& & \\
\end{tabular}

(a): Betreffende variabele is een dumy variabele.

(b): Betreffende variabele is logaritmisch getransformeend 
Richard Janssen werd geboren op 7 februari 1954 te Ysselsteyn bij Venray. Hij volgde zijn middelbare schoolopleiding aañ het Boschveldcollege te Ventay Na het eindexamen Gymnasium-B in 1972 studeerde hil economie aln de toenmalige Katholieke Hogeschool Tilburg (tegenwogrdig Katholieke Universiteit Brabant). In 1978 studeerde hij af in de economisch-sociologische specialisatie. Van 1978 tot miedio 1982 was hij werkzaam als docent teconomie bij de toenmalige Katholieke Stichting Saciaal-; Pedagogisch Onderwijs Limbutg (tegerwoordig Hogeschool Sittard). Sindsdien is hij in dienst van de Rijksuniversiteit Limburg, alwaar hij werkzaam is bij de vakgroep Economie van de Gezondhetdszorg "Binnen dit dienstverband verricht hif werkzaamheden zowel op het terrein van onderwijs als onderzoek. Naast dit promotieonderzoek deed hij onderzoek en publiceerde hij op het terrein van de solidariteit in: deziektekostenwerzekering en de structurr var de politieke bestuitvorming ten aamzin van de gezondheidszorg in Nederland.

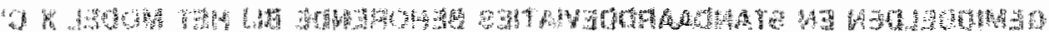

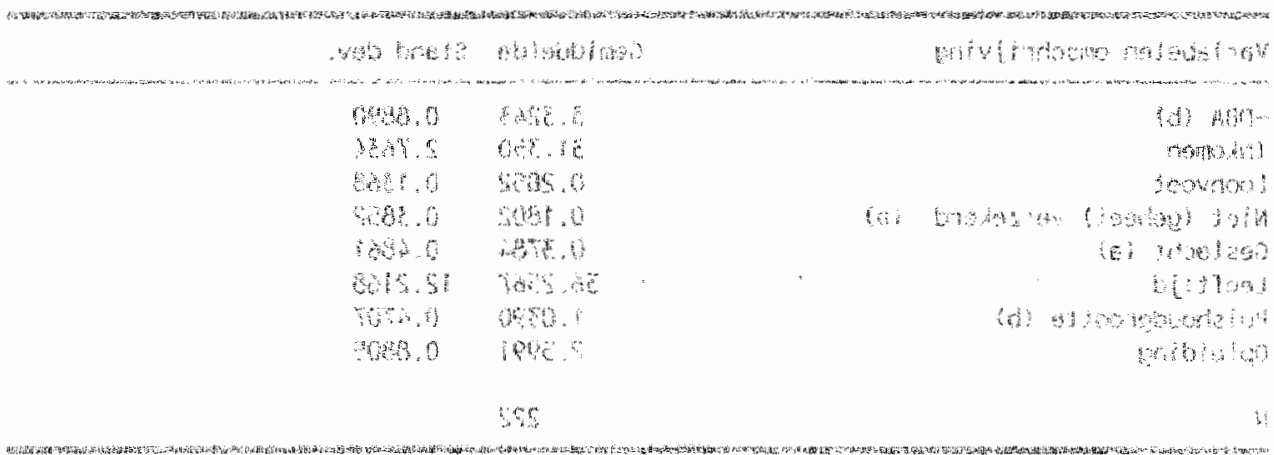

